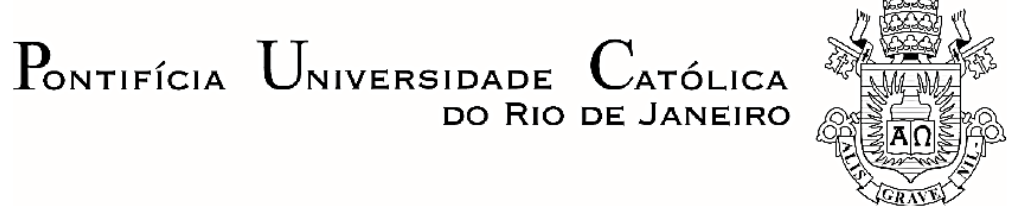

Larissa Kouzmin-Korovaeff

O CASO SINGULAR D'O LIVRO VERMELHO

DE C. G. JUNG

Dissertação de Mestrado

Dissertação apresentada como requisito parcial para obtenção do grau de Mestre pelo Programa de Pós-graduação em História Social da Cultura do Departamento de História da PUC-Rio.

Orientador: Prof. Ronaldo Brito Fernandes

Rio de Janeiro

Dezembro de 2019 
Pontifícia Universidade Católica

\title{
Larissa Kouzmin-Korovaeff
}

\section{O CASO SINGULAR D'O LIVRO VERMELHO \\ DE C. G. JUNG}

Dissertação apresentada como requisito parcial para obtenção do grau de Mestre pelo Programa de Pós-graduação em História Social da Cultura do Departamento de História da PUC-Rio.

\author{
Prof. Ronaldo Brito Fernandes \\ Orientador \\ Departamento de História - PUC-Rio \\ Prof. Maddi Damião Junior \\ Departamento de Psicologia - UFF
}

Prof. José Thomaz Brum

Departamento de História - PUC-Rio

Rio de Janeiro, 10 de dezembro de 2019 
Todos os direitos reservados. É proibida a reprodução total ou parcial do trabalho sem autorização da universidade, da autora e do orientador.

\section{Larissa Kouzmin-Korovaeff}

Possui graduação em Design Gráfico pela Universidade Estácio de Sá (2011). Especialista em Publisher Managament: O Negócio do Livro pela FGV (2012). Pós-graduanda em Arteterapia e Processos de Criação pela UVA (2019). Designer, editora e sócia proprietária da Semente Editorial, Consultora editorial e Diretora de eventos da Liga Brasileira de Editores Independentes.

Ficha catalográfica

Kouzmin-Korovaeff, Larissa

O caso singular d'O Livro Vermelho de C. G. Jung / Larissa Kouzmin-Korovaeff ; orientador: Ronaldo Brito. - 2019.

198 f. : il. color. ; $30 \mathrm{~cm}$

Dissertação (mestrado)-Pontifícia Universidade Católica do Rio de Janeiro, Departamento de História, 2019.

Inclui bibliografia

1. História - Teses. 2. História Social da Cultura - Teses. 3. Livro raro. 4. Livro de artista. 5. Processo criativo. 6. Obra de arte. 7. Psicologia junguiana. I. Brito Fernandes, Ronaldo. II. Pontifícia Universidade Católica do Rio de Janeiro. Departamento de História. 
Dedico,

Ao Namur Gopalla (in memoriam), de quem ouvi pela primeira vez sobre símbolos e arquétipos.

Não tive oportunidade de dizer-lhe o quanto admirei sua dignidade na conduta consigo mesmo.

À Angela Casagrande da Silva Camargo (in memoriam), avó materna que, na intenção de compensar a falta de estudo, caprichava no bonito da letra e dizia: não deixe de estudar, hem, menina! 


\section{Agradecimentos}

O presente trabalho foi realizado com apoio da Coordenação de Aperfeiçoamento de Pessoal de Nível Superior - Brasil (CAPES) - Código de Financiamento 001.

Agradeço a meu pai, Constantino, com quem aprendi o amor pela coisa livro e seu ofício, a minha mãe, Maria, pois com ela aprendi o amor pela leitura. A Mirian, pela parceria e confiança do primeiro livro, incentivo e primeiras e últimas leituras desta pesquisa. Aos filhos, Zoatha, Raisa e Giovanna, pelo encorajamento, ajuda e paciência diante dos momentos de desânimo, cansaço ou mau humor. Agradeço à Naruta e Vaquita, companheiras incondicionais, sempre presentes e atentas ao meu estado de espírito. E, especialmente, ao Jeronimo, companheiro e escudeiro incansável, pelo reconhecimento, compreensão e apoio integral.

Agradeço a todos os professores que contribuíram com meu percurso compartilhando de sua luz e conhecimento; foram muitos. Ao acolhimento da PUC, por meio de seus funcionários e da instituição. Particularmente, ao professor Maddi Damião, que gentil e generosamente acompanhou o processo de pesquisa antes mesmo que se consolidasse como projeto - foi quem viu claramente e entendeu o que eu estava vendo -, dispondo-se a orientar-me sempre e quando eu precisasse, integrando inclusive a banca examinadora. A Simone Machado, que me ensinou os princípios da escrita acadêmica para elaboração do pré-projeto. Ao professor José Thomaz Brum, pelo seu interesse inicial e participação na banca examinadora, e ainda, por ter-me apontado o norte no momento em que me sentia perdida. E agradeço ao meu orientador, Ronaldo Brito Fernandes, por ter tido a generosidade de aceitar meu projeto e pelo acompanhamento sempre preciso.

Por fim, agradeço ao mestre Prem Rawat - por meio de seu conhecimento abri meus olhos para as coisas que realmente importam. 


\section{Resumo}

Kouzmin-Korovaeff, Larissa; Brito Fernandes, Ronaldo. O caso singular d'O Livro Vermelho de C. G. Jung. Rio de janeiro, 198pp. Dissertação de Mestrado - Departamento de História, Pontifícia Universidade Católica do Rio de Janeiro.

O propósito desta pesquisa é qualificar O Livro Vermelho de C. G. Jung como obra de arte. Para isso buscou-se primeiramente quais os conceitos e critérios de validação do livro como tal. Circunscritas as espécies que transitam nessa categoria - livros raros e livros de artista - contemplamos, por meio de um percurso histórico pela história do livro, suas especificidades, pressupostos e aproximações, pois, se por um lado, semelhante aos manuscritos medievais iluminados, tal publicação revigora o livro como obra de arte, por outro lado o processo de criação da obra rompe com o paradigma da feitura do livro através de um processo colaborativo e especializado em vigor desde aquela época, no qual, tradicionalmente, o autor escreve textos, não produz livros. Essa mudança de paradigma vem a ser um dos principais pressupostos da categoria que recoloca na história o livro como obra de arte por meio do campo do livro de artista - em seu sentido lato -, segundo o qual o autor não apenas escreve, mas faz o livro, e estuda-se a si mesmo no processo, então como circunscrevê-lo? Com isso esperamos atingir o objetivo subjacente ao tema central - resgatar o valor cultural e artístico do livro, ressaltando o potencial plástico e criativo que ele oferece.

\section{Palavras-chave:}

Livro raro; livro de artista; processo criativo; obra de arte; psicologia junguiana. 


\section{Abstract}

Kouzmin-Korovaeff, Larissa; Brito Fernandes, Ronaldo. The Singular Case of The Red Book by C. G. Jung. Rio de Janeiro, 198pp. Master Degree Thesis - Department of History, Pontifical Catholic University of Rio de Janeiro.

The purpose of this research is to qualify The Red Book of C.G. Jung as a work of art. For this, we first sought what concepts and validation criteria of the book as such. Circumscribed the species that pass through this category - rare books and artist books - we contemplate, through a historical journey, through the history of the book, its specificities, assumptions and approximations, because, if on the one hand, similar to the illuminated medieval manuscripts, such publication reinvigorates the book as a work of art, on the other hand, the process of creation of the work breaks with the paradigm of book making through a collaborative and specialized process in force since that time, in which, traditionally, the author writes texts, does not produce books. This paradigm shift is one of the main assumptions of the category that relocates in history the book as a work of art through the field of the artist's book - in its broad sense - according to which the author not only writes, but makes the book, and is studied to himself in the process, so how to circumscribe it? With this we hope to achieve the objective underlying the central theme - to rescue the cultural and artistic value of the book, highlighting the plastic and creative potential it offers.

\section{Keywords}

Rare book; artist book; creative process; work of art; Jungian psychology. 


\section{Sumário}

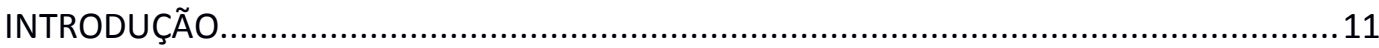

1. A POÉTICA D'O LIVRO VERMELHO DE C. G. JUNG - História, ética e estética ...............25

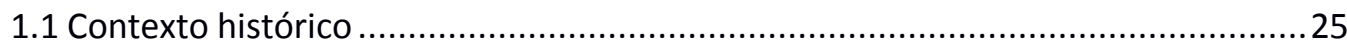

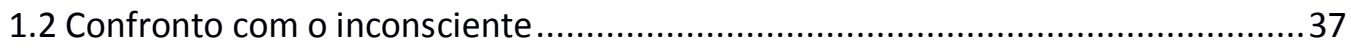

1.30 processo de criação d'O Livro Vermelho .........................................................42

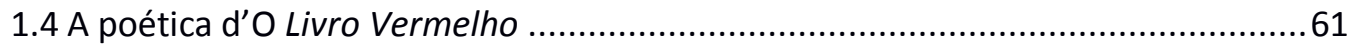

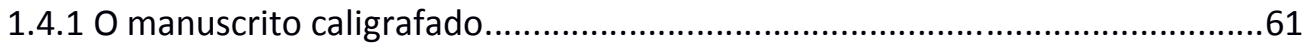

1.4.2 Pinturas - iluminuras e inicias iluminadas ou historiadas .............................67

1.4.3 Linguagens - mitopoética, simbólica, profética.........................................75

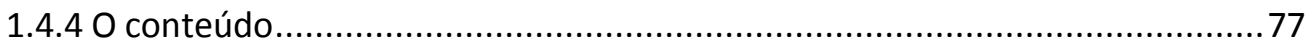

1.5 A expertise autodidata do artista moderno na construção de uma poética ......79

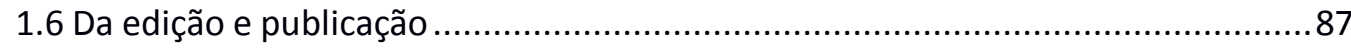

2. O LIVRO COMO OBRA DE ARTE - Contexto histórico e contemporâneo ......................91

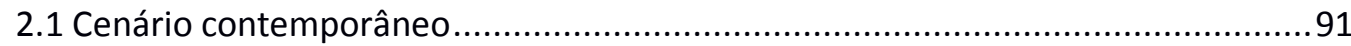

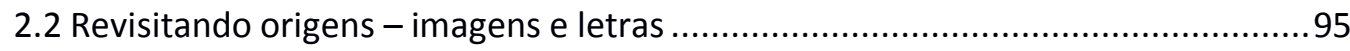

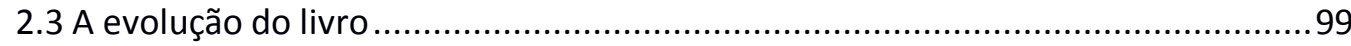

2.4. O livro raro como obra de arte - fundamentos e conceitos..............................105

2.50 livro raro, precioso e único - obra de arte e patrimônio cultural .....................111

2.6 Livros raros e livros de artistas - especificidades e aproximações ........................113

3. OS MANUSCRITOS MEDIEVAIS ILUMINADOS - O livro raro que habita o nosso

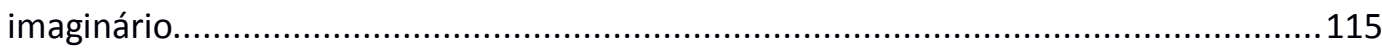

3.1 Iluminuras - uma arte para agradar aos olhos de Deus .....................................126

3.2 Iluminuras - especificidades, processos, estilos ............................................. 137

4. LIVRO DE / DO ARTISTA - A nova arte de fazer livros ............................................. 148

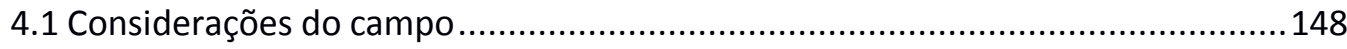

4.2 Dos manuscritos iluminados à ilustração editorial ..............................................154

4.3 O desenvolvimento do campo da gravura e a massificação da imagem impressa

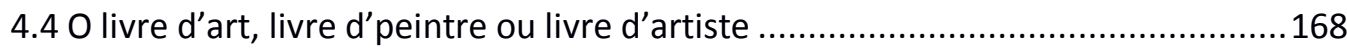

$4.5 \mathrm{O}$ campo do livro de artista e o potencial plástico do livro .................................176

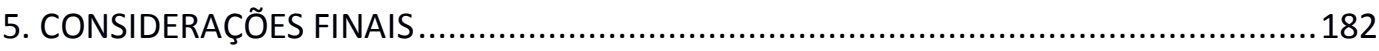

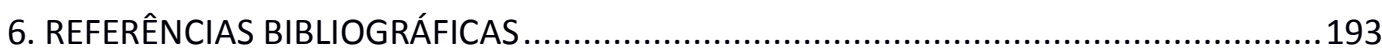




\section{Lista de Figuras}

Figura 1: Ilustração "Brahmanaspati" (p 54/LV).....................................................................36

Figura 2: Ilustração sem título da (p 131 /LV) .................................................................... 41

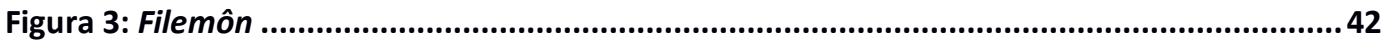

Figura 4: Esboços de mandalas...............................................................................................51 51

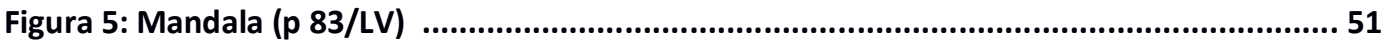

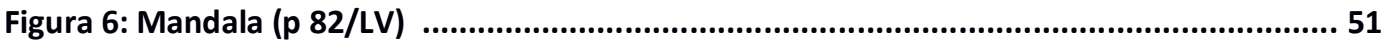

Figura 7: Mandala (p 121 /LV) ..............................................................................................55

Figura 8: Mandala "Uma flor luminosa no centro com estrelas girando ao seu redor" (p

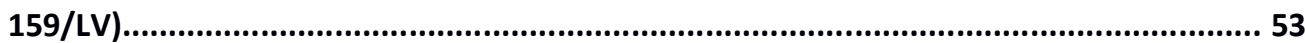

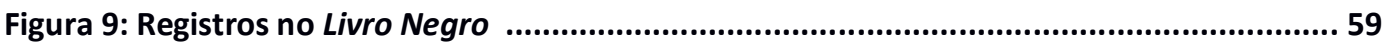

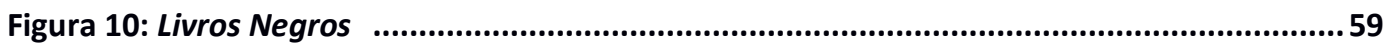

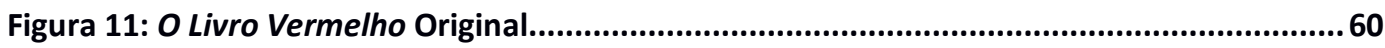

Figura 12: Ilustração sem título da série "Encantações" .......................................................61

Figura 13: Iluminura manuscrita com caligrafia gótica ........................................................62

Figura 14: Detalhe de caligrafia gótica .............................................................................66

Figura 15: Iluminura $p(11$ e 13/ LV) .................................................................................68

Figura 16: Iluminuras: "Quando eu falo em espírito" (fólio I/LV); "O reencontro da alma" (fólio

I/LV); “Alma e Deus" (fólio II/LV); "Sobre o serviço da alma" (fólio II/LV)........................... 69

Figura 17: Detalhe de Ilustração........................................................................................... 70

Figura 18: Ilustração “O solitário" (p 133/LV)..........................................................................71

Figura 19: Ilustração sem título da série "Encantações" (p 55/LV) ..........................................73

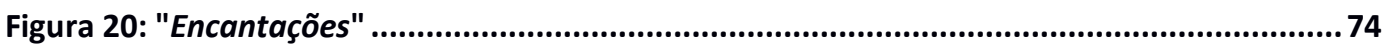

Figura 21: Exposição de lançamento .................................................................................89

Figura 22: Exposição na 55a edição da Bienal de Veneza......................................................89

Figura 23: Retirada do LV do cofre por onde esteve guardado por décadas ............................. 90

Figura 24: Manuscrito medieval iluminado ...........................................................................99

Figura 25: Leitura com o rolo de papiro "Volumen" ........................................................ 120

Figura 26: Leitura com o códice........................................................................................... 120

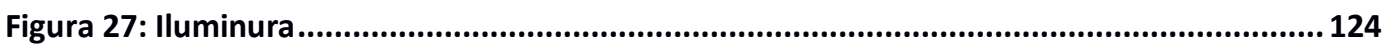

Figura 28: Iluminura do Livro de Kells ....................................................................... 125

Figura 29: Iluminura do Evangelho de Lindisfame........................................................... 144

Figura 30: Iluminura do Livro de Kells ................................................................................. 144

Figura 30: Iluminura do Evangelário de Ebbo ................................................................... 146

Figura 32: Precursores do Livro de Artista .................................................................. 152

Figura 33: Caderno de esboços de Van Gogh.................................................................... 153

Figura 34: Página dupla de Of The Friendship Of Amis And Amile - Kelmscott Press, ............. 170

Figura 35: Páginas do livro Song of Solomon - Eragny Press ................................................ 171

Figura 36: Página dupla de Abregé de L'art Poetique Française - Eragny Press....................... 172

Figura 37: Página da Dove's Bible - Doves Press ............................................................ 173

Figura 38: Encadernação da Doves Press....................................................................... 173

Figura 39: Amostra de Livros de Artista....................................................................... 181

Figura 40: Ilustração sem título (p 135 / LV).................................................................... 192 
Dos diversos instrumentos do homem, o mais assombroso, sem dúvida, é o livro. Os demais são extensões de seu corpo. O microscópio, o telescópio, são extensões de sua vista; o telefone é extensão da voz; depois temos o arado e a espada, extensões de seu braço. Mas o livro é outra coisa: o livro é uma extensão da memória e da imaginação ${ }^{1}$

\footnotetext{
${ }^{1}$ BORGES, J. L. Cinco visões pessoais. In “O livro”. Brasília: Ed. UnB, 1985.
} 


\section{INTRODUÇÃO}

Provavelmente existem poucos trabalhos inéditos que exerceram efeitos tão vastos sobre a história social e intelectual do século XX quanto O Livro Vermelho de C. G. Jung, ou Liber Novus (livro novo). Assim chamado por Jung por conter o núcleo de seus trabalhos tardios, já foi reconhecido como a chave para a compreensão da gênese desses trabalhos ${ }^{2}$.

O propósito desta pesquisa é qualificar O Livro Vermelho de C. G. Jung como obra de arte. Para isso buscou-se primeiramente quais os conceitos e critérios de validação do livro como tal. Circunscritas as espécies que transitam nessa categoria - livros raros e livros de artista - contemplamos por meio de um percurso histórico pela história do livro, suas especificidades, afinidades e aproximações, visto que o livro em questão apresenta, por um lado, a estética de um livro raro, e por outro vai ao encontro do processo de criação do livro de artista, segundo o qual o autor não apenas escreve, mas faz o livro, e estuda-se a si mesmo no processo. Com isso esperamos atingir o objetivo subjacente ao tema central - resgatar o valor cultural e artístico do livro, ressaltando o potencial plástico e criativo que ele oferece.

Nos primeiros anos do novo milênio, enquanto o mundo discutia o futuro (in)certo do livro impresso face ao advento do livro digital, foi publicado em 2009 O Livro Vermelho, de Carl Gustav Jung. A obra surpreende - causa admiração e espanto. Com aparência ${ }^{3}$ de livro raro e precioso, remete-nos imediatamente à estética dos manuscritos medievais iluminados. Trata-se de uma edição fac-

\footnotetext{
2 JUNG, C. G. O Livro Vermelho de C. G. Jung. In Introdução por Sonu Shamdasani. 4ạ ed. (edição sem ilustrações) Ed. Vozes Petrópolis / RJ (2015). Sonu Shamdasani é historiador da psicologia e psiquiatria, e professor de História de Jung no Wellcome Trust Centre for the History of Medicine, no University College London. Autor de diversos livros. Editor-geral da Fundação Philemon. Editor e organizador d'O Livro Vermelho.

${ }^{3}$ Heidegger em Ser e Tempo (2015, p 67) comenta que no significado de Scheinen enquanto aparecer, parecer, aparência, está incluído o significado original de fenômeno como o que se revela, entretanto, o que se mostra pode mostrar-se como aquilo que em si mesmo ele não é, como a possibilidade de algo mostrarse como aquilo que, em si mesmo, ele não é. "Neste modo de mostrar-se o ente 'se faz ver assim como'... do que parece". O Livro Vermelho, fenomenologicamente, mostra-se, revela-se, se faz ver "como se" fosse um manuscrito medieval iluminado, no entanto, em si mesmo, não o é.
} 
similar com formato de livro de mesa $-30 \mathrm{~cm}$ x $40 \mathrm{~cm}$, lombada com $10,5 \mathrm{~cm}$ e pesando $4 \mathrm{~kg}$-, fidedigna ao original, um exemplar único. Caracteriza-se por uma composição artística de elementos linguísticos e visuais por meio dos quais a narrativa mitopoética, manuscrita em caligrafia ${ }^{4}$ gótica e pinturas de capitulares e iluminuras de grande densidade simbólica, conta-nos a história de um homem que vai ao encontro de sua alma. A paleta revela um colorista. Um Jung surpreendente - o artista, o poeta, desvela-se no conjunto da obra.

Realmente, com sua aparência originalíssima, seu formato em pergaminho e suas ilustrações medievais inseridas em formato de iluminuras, o Livro Vermelho não encontra similares na literatura contemporânea [...]. Escrevendo cuidadosamente em letra gótica ${ }^{5}$, Jung deu às palavras características especiais, quase como se fossem pequenos desenhos. Nos inícios dos capítulos ornamentou as letras maiúsculas com significativas iluminuras, à moda medieval ${ }^{6}$. As próprias ilustrações seguem o modo da têmpera, maneira de ilustrar das ilustrações que ornamentavam os altares medievais antes do advento da técnica óleo sobre tela ${ }^{7}$.

O confronto face ao contexto contemporâneo no qual a obra emerge tecida com questões que colocam em xeque a permanência do livro em nossa cultura tal qual o conhecemos, chegando até mesmo à anunciação de seu fim realça sua aura $^{8}$ de coisa rara, revalidando com isso o potencial do livro como

\footnotetext{
4 Conhecida como "a arte da bela escrita", conforme descreve Gabriela Irigoyen - artista plástica internacionalmente reconhecida que se dedica à encadernação artística -, a caligrafia é vista pelo senso comum como coisa antiga e ultrapassada, no entanto, trata-se de um tema antigo que remonta às origens da escrita e da nossa sociedade grafocêntrica. Na contemporaneidade, em meio à desmaterialização da escrita e dos meios impressos, a caligrafia ressurge pela arte que a redimensiona ao se apropriar do ato e do gesto de escrever como elemento estético e não apenas funcional. In artigo-portifólio "Cláudio Gil". Revista Gráfica \# 75/76, 2011.
}

5 Escrita ou letra gótica é o nome pelo qual é chamada o tipo de letra angulosa e com linhas quebradas originada entre os séculos XII e XIII. Usada na Europa ocidental até cerca de 1500, tal estilo caligráfico e tipográfico continuou a ser utilizado na língua dinamarquesa até 1875 , e em países de língua alemã até o século XX. A Bíblia de Gutenberg - primeiro incunábulo da Europa Ocidental - foi impressa em tipos góticos.

${ }^{6}$ Isto é, composto de acordo com as referências do estilo medieval de modo a "aparecer e parecer" como tal. Vide nota 2.

${ }^{7}$ BOECHAT, Walter. O Livro Vermelho de Jung - jornada para profundidades desconhecidas. Rio de Janeiro: Vozes, 2014. Walter Boechat é médico e analista junguiano, membro-fundador da Associação Junguiana do Brasil. Tem diversas publicações no Brasil e no Exterior.

${ }^{8}$ BENJAMIN, Walter. A obra de arte na época de sua reprodutibilidade técnica. Porto Alegre: Ed. Zouk, 2012. Aura, segundo o conceito benjaminiano, designa os elementos únicos de uma obra de arte original. Para o autor, a aura relaciona-se à autenticidade, à existência única de uma obra de arte. Estamos nos referindo ao livro original e único, que na ocasião da publicação a partir do fac-símile foi exposto (como veremos mais 
obra de arte e revigorando o valor do que acreditamos ser o mais significativo objeto cultural ocidental - o livro. Acontece que o manuscrito foi apontado pelo autor como pedra angular de sua psicologia. Carl Gustav Jung (1875-1961) ocupa um lugar distinto na história do pensamento ocidental moderno por ter sido um dos fundadores da psiquiatria, psicoterapia e psicologia modernas ${ }^{9}$. A evidência do reconhecimento e repercussão de sua obra - organizada em 19 volumes nas Obras Completas, variados artigos e conferências publicados, contando ainda com uma série de textos inéditos ${ }^{10}$-, pode ser comprovada no uso cotidiano de conceitos que ele criou e/ou utilizou em seu trabalho - complexo, inconsciente coletivo, introversão, extroversão, anima, animus, persona, sombra, sincronicidade, entre outros ${ }^{11}$. Outrossim, suas ideias, assim como as de Freud, foram amplamente disseminadas e incorporadas nas artes, nas humanidades e na cultura popular ${ }^{12}$. Todavia, a obra, escrita e reescrita entre 1913 e 1929, e inacabada, permaneceu indisponível. Entre a concepção, a gaveta de seu autor, e, postumamente, o cofre de um banco com condições de conservação e segurança máximas, atravessou o século XX em sigilo, de modo que não se esperava por tal publicação $\operatorname{tardia}^{13}$. A primeira referência pública quanto à existência de obra

adiante) em diversos museus. Se, por um lado, como diz Walter Benjamin, a reprodução enfraquece a aura da obra, há que se considerar a diferença da relação original x cópia na categoria livro. No caso em questão, a força com que a quintessência da obra vigora, mesmo em suas reproduções face ao contexto contemporâneo do campo em questão.

${ }^{9}$ JUNG, C. G. O Livro Vermelho de C. G. Jung. In "Introdução” por Sonu Shamdasani (p 1). Petrópolis: Vozes, edição sem ilustrações, 2017.

${ }^{10}$ O Livro Vermelho é a principal iniciativa de Fundação Philemon, organização que tem por fim a publicação das obras completas de Jung. Pesquisas das obras completas demonstraram que os dezenove volumes publicados não abrangem a totalidade de seu material escrito. Na verdade, as obras não publicadas abrangeriam praticamente o dobro das obras até aqui publicadas como completas. (...) a tradução exata do título original Collected Works das chamadas Obras Completas de C. G. Jung pela editora inglesa Routledge ou pela norte-americana Princeton é Obras Coligidas, isto é, escolhidas, selecionadas, e não Obras Completas". In O Livro Vermelho de C. G. Jung - jornadas para profundidades desconhecidas por Walter Boechat (p 23). Petrópolis: Vozes, 1ạ edição, 2014.

${ }^{11}$ SOUZA, F. L. M. "O Livro Vermelho de Jung: As polaridades da psique e as concepções de Deus". Tese de Doutorado apresentada ao Programa de Pós-Graduação em Ciência da Religião, área de concentração Filosofia da Religião, do Instituto de Ciências Humanas da Universidade Federal de Juiz de Fora / MG, 2015.

12 JUNG, op. cit. In "Introdução" por Sonu Shamdasani. (2015, p 1) Sonu Shamdasani é autor, editor e professor na University College London. Seus escritos cobrem a história da psiquiatria e da psicologia desde meados do século XIX até os tempos atuais; especialista em história da psicologia junguiana.

${ }^{13}$ Jung tinha dúvidas sobre o que fazer com esse material, e, ainda que tenha pensado efetivamente em publicar o LV, nunca deu os passos necessários. “Em 1957, Jung declarou que os Livros Negros e o Livro 
inédita que continha essencialmente a gênese da psicologia analítica, deu-se em 1961, com a publicação de Memórias, Sonhos e Reflexões ${ }^{14}$. Jung descreve, então, a maneira pela qual, por meio de uma experimentação psíquica a que se propôs, desdobra-se o processo criativo ${ }^{15}$ de suas mandalas e pinturas - obras visuais desconhecidas e anônimas -, resultando na criação d'O Livro Vermelho como registro e produto do processo, e, sobretudo, como caldo de cultivo das premissas segundo as quais elaborou o cerne de sua psicologia. Tal escrito, editado e incluído na obra organizada por Aniela Jaffé - considerada, apesar das controvérsias $^{16}$, sua autobiografia - pode ser visto como uma introdução ao Liber Novus $^{17}$. A partir dessa revelação primária - insuficiente para dar conta da totalidade da obra e do lugar fundamental que ocupa no desenvolvimento de Jung -, muito se especulou a respeito na literatura secundária. É realmente espantoso que só tenha sido publicado quase um século depois de sua gênese e 48 anos após a morte de Jung.

Por quase um século, essa leitura simplesmente não foi possível, e a vasta literatura que surgiu sobre a vida e obra de Jung não teve acesso à mais importante fonte documentária individual. A presente publicação marca uma cesura, e abre a possibilidade de uma nova era na compreensão da obra de Jung. Fornece uma abertura única para ver como ele recuperou sua alma e, ao fazê-lo, elaborou uma psicologia ${ }^{18}$.

Vermelho eram registros autobiográficos que ele não queria publicados em suas Obras Completas, porque não tinham caráter erudito". JUNG, op. cit. In prefácio por Ulrich Hoerni. (2017)

14 JUNG, Carl Gustav. Memórias, sonhos e reflexões. Rio de Janeiro: Nova Fronteira, 2016. Autobiografia organizada por Aniela Jaffé e publicada originalmente em 1961. Psicanalista alemã, trabalhou no Instituto C. G. Jung e foi secretária particular de Jung.

${ }^{15}$ Fayga Ostrower em Criatividade e Processos de Criação (2014) define processos criativos como processos formadores, ordenadores e configuradores, por meio dos quais se realiza o potencial criador inerente ao homem. Enquanto potencial, a criatividade encerra múltiplas possibilidades, todavia, para realizar-se concretamente os determinantes da matéria plástica e as escolhas que o artista faz durante o ato criador trazem o virtual para a realidade concreta. O processo criativo pode ser definido como um pensar específico sobre um fazer concreto motivado pela necessidade interior de realizar tal potencial. Embora integrem toda a experiência possível ao indivíduo, inclusive a racional, para Fayga o processo criativo ocorre no âmbito da intuição, pois desvela mundos dantes ocultos ou latentes ao olhar do mundo.

16 JUNG, op. cit. (2016)

${ }^{17}$ Ibid. (p1) Jung refere-se à obra tanto como Liber Novus quanto como O Livro Vermelho, como ficou universalmente conhecido.

18 JUNG, op. cit. In “Introdução" por Sonu Shamdasani. (2015, p 86) 
Invariavelmente - para os que esperavam pela oportunidade de vê-lo ou, ainda, para os poucos que já tinham tido alguns vislumbres atormentadores ${ }^{19}$-, perplexidade é a palavra que define a experiência de estar diante da obra, pois o espanto diante de uma perspectiva tão original e radical, que concatena fundamentalmente a obra visual de Jung com sua obra científica, produz uma ruptura, uma virada no pensamento tão intensa, que leva psicólogos, pesquisadores, historiadores, artistas etc., a refletir a respeito de suas crenças e concepções. A irrupção do campo da arte quebra com o modelo psicológico racional reducionista. A inserção de técnicas expressivas em suas práticas adquire outro significado; toda a obra de Jung e a constituição de sua psicologia, que se fez pela ordem do simbólico, são vistas sob outra luz. Surpreendentemente, sem teorias. A estética da obra e seu processo de criação saltam aos olhos, e o que viria a ser edição, publicação e lançamento de obra literária amplia-se, ainda, para exposição de livro como obra de arte em diversos museus internacionais.

Este fac-símile exato do Livro Vermelho revela não só uma mente extraordinária em ação, mas também a mão de um artista e calígrafo talentoso. Intercalados por entre (cerca de) 200 páginas graciosamente iluminadas, encontram-se quadros cujas influências vão desde a Europa, o Oriente Médio e o Extremo Oriente até a arte nativa do Novo Mundo. O Livro Vermelho, assim como o Livro das Horas artesanal da Idade Média, é algo único. Tanto em termos de seu lugar no desenvolvimento de Jung, quanto como obra de arte, sua publicação é um marco divisório ${ }^{20}$.

Meu contato inicial com $O$ Livro Vermelho deu-se por ocasião de seu lançamento no Brasil, em julho de 2010. Estava participando pela primeira vez da Flip - o mais importante festival literário internacional do país, que acontece anualmente desde 2003 - em Paraty. Joia do período colonial brasileiro, cidade localizada em meio à paisagem exuberante entre a serra e o mar, tem ainda o encanto de, vez por outra, tomada pela alta das marés, transformar-se, no imaginário popular, em uma Veneza brasileira. Entretanto, durante o festival literário, tudo em Paraty é inundado pelos livros e seus amantes. Eles estão por

\footnotetext{
${ }^{19} \mathrm{Idem}$.

${ }^{20}$ JUNG, C. G. O Livro Vermelho de C. G. Jung. In contracapa. Petrópolis: Vozes, edição com ilustrações, 2017.
} 
toda parte, nas ruelas, vielas, esquinas, casarios, pátios e, ainda, a bordo dos barcos, e dependurados pelas árvores e telhados da cidade. Durante esses dias acontece um fenômeno raro, a bibliodiversidade - mariginalizada pela imposição do grande mercado - aflora livre e exuberante.

Pois bem, lá estava eu, recém-formada em design editorial, terminando uma especialização, "Publisher Management - O mercado do livro", e refletindo sobre como e por onde entrar nesse mercado, relativamente restrito, sobretudo para alguém que como eu, aos 40 anos, havia sido até então microempreendedora. Fazer livros parece fácil, mas não é. $O$ objeto apresenta uma tecnologia aparentemente simples. Confeccionado com matéria-prima acessível, não necessita de fonte de energia ou bateria para funcionar; é portátil, sem contraindicações, pode ser consumido sem restrições, e, se mantido em condições ideais de conservação, perdura por séculos. No entanto, para fazê-los, necessita-se diversas competências, e cabeças e olhares e mãos e coração. E, ainda, para trazêlos ao mundo, uma orquestração afinada entre os elos criativo, produtivo e industrial. Desse modo, exige-se experiência no trato com tais objetos. Ademais, as perspectivas não se mostravam promissoras. Com o advento da internet, a experiência e os hábitos de leitura estavam em franca transformação e declínio; o e-book prenunciava-se como sucessor do livro impresso em uma visão apocalíptica; e a edição e publicação de livros sob demanda, que se apresentavam como caminho possível, não eram bem-vistas. Contudo, sentia-me feliz. Havia produzido um primeiro livro, Confraria Van Gogh - a vida secreta de um livro de biblioteca pública ${ }^{21}$, por meio do qual, embora não soubesse ainda, encontrei meu lugar como editora independente (conceito que à época estava em construção) e dei-me conta de que face à falta de experiência objetiva, eu havia adquirido de alguma forma, por osmose, as habilidades do meu pai, também designer e editor. Com essa primeira produção tivera minha iniciação, e compreendi, de modo decisivo, uma sentença que deixa a maioria dos autores perplexos: "O autor não escreve livros, o autor escreve textos" ${ }^{\text {,22 }}$. Sim! O livro é produto de um processo

\footnotetext{
${ }^{21}$ CAVALCANTI, Mirian. Confraria Van Gogh - a vida secreta de um livro de biblioteca pública. Divino de São Lourenço: Semente Editorial, 2010.

${ }^{22}$ CARRIÓN, U. A nova arte de fazer livros. Belo Horizonte: Ed. C/Arte, 2011. Ulisses Carrión foi um dos primeiros autores a escrever sobre livros de artista. Seu livro, lançado em 1975, publicado como artigo em 1980 pela Second Thoughts, Void Distributors - Amsterdam, ganhou o mundo tornando-se uma importante referência bibliográfica. Poeta, artista, organizador de exposições e de seus próprios catálogos; bibliotecário
} 
colaborativo e especializado que envolve diversas competências. E tem sido assim desde quando eram produzidos no scriptorium medieval.

[...] todo monastério possuía um scriptorium. Lá era o lugar onde eram copiados, decorados e encadernados os manuscritos. [...] uma divisão rigorosa do trabalho e uma organização sem falhas regem o nascimento dos manuscritos. Para a formação de um escriba, eram considerados necessários, pelo menos, sete anos de aprendizado com um mestre-artesão ${ }^{23}$.

Nesse cenário e em tal contexto, deparei-me com uma pilha imponente de livros vermelhos, sobre os quais um exemplar em exposição exibia um par de páginas. A experiência diante da obra fora realmente impactante - a aura do objeto provocada pelos rastros do processo manuscrito; a intensidade das cores e o jogo de transparências e opacidade; a textura caligráfica com suas tessituras visuais; as iluminuras de grande densidade simbólica; a relação de escala entre o preto e o acinzentado como indício do nanquim que se acabava - tudo ali traduzia-se em autenticidade. Não sei se existe este conceito, mas o nomearia como "estética da presença". Evidente que fosse o que ali estivesse escrito, tratava-se de algo extremamente significante e valoroso para o autor. Vi que era Jung. Eu o conhecia da leitura de O Homem e Seus Símbolos, no entanto, a imagem da obra ficou interiorizada de tal forma, que isso me era irrelevante. $\mathrm{O}$ livro ficou lá, não o pude adquirir, mas sua lembrança seguiu comigo.

Alguns anos depois, em 2014, o reencontrei. Procurava uma pósgraduação que tivesse aulas práticas de arte, e tudo o que havia disponível no Rio de Janeiro eram cursos teóricos. Deparei-me então com a pós em "Arteterapia e Processos de Criação", embora não tivesse nenhuma intenção de vir a ser terapeuta, a ementa multidisciplinar transitando pelos campos da arte, educação e psicologia, interessou-me profundamente, além de oferecer aulas práticas e contextualizadas com a história da arte. Foi um achado. Considero ter apreendido, ali, mais sobre a natureza da arte, essencialmente, do que no campo stricto da história da arte. E, ainda que indiretamente, acrescentou muito ao meu trabalho

\footnotetext{
e crítico de arte. Cursou Filosofia e Literatura na Universidade do México e na Sorbonne. Publicou vários livros antes de começar a trabalhar com a linguagem fora do contexto literário ou ensaístico.

${ }^{23}$ GEORGES, Jean. Escrita: memória dos homens. Rio de Janeiro: Objetiva, 2008. (p 154) Professor de linguística geral e semiologia na Universidade do Condado de Maine; autor de mais de sessenta obras.
} 
editorial e às oficinas livres que ofereço, com o diferencial de ter contribuído para com o meu processo de autoconhecimento.

No curso, com abordagem junguiana, deparei-me novamente com sua obra e com $O$ Livro Vermelho. Ao conhecer as especificidades por meio das quais o processo criativo da obra vinculara-se à elaboração das premissas de sua psicologia, dei-me conta de que ele havia aproveitado toda a potência que a coisa livro, como suporte poético, tem para oferecer - matéria plástica, espaço de criação, campo de presença, desdobramento e morada no tempo -, e pensei: esse trabalho foi, em seu sentido lato, o livro de artista de Jung.

No sentido lato, "Livro de Artista" é entendido como um campo de atuação artística (uma categoria) e, simultaneamente, como o produto desse campo, um resultado quase específico das artes visuais. Dentro de tal campo, experiencial e relacional entre obra e artista, há diversas qualificações para distinguir o produto específico que se forma, tais quais: livro de artista, livro-objeto, arte-livro, livro-poema, poema-livro, livro ilustrado, livro-obra, livro-processo - dentre outras variantes ${ }^{24}$.

Afora o espanto e o encanto que sentia diante da poética da obra e suas relações intrínsecas, havia um contexto histórico relevante, atrelado ao seu percurso singular - concepção contemporânea ao surgimento do campo do livro de artista no âmbito da arte moderna; estética que ia ao encontro dos manuscritos medievais iluminados; e publicação na esfera da arte contemporânea -, o que abria a possibilidade de transitar por tais períodos a fim de circunscrever as relações que se dão entre os modelos referidos, espécies que, inclusive, constelam a história do livro tal qual o conhecemos, desde os primeiros manuscritos até nossa contemporaneidade. Isto é, subjacente ao tema, estava a coisa livro, meu objeto de real interesse. Abordar o seu potencial artístico fora de um contexto determinante ou preestabelecido colocava-me diante de alguns muros, mas por outro lado abriam-se janelas para novos sentidos. Eu queria abordar o potencial plástico e criativo do livro, sem que para isso tivesse que dissecá-lo. O Livro Vermelho, singular, oferecia-me, por meio de uma perspectiva polissêmica, uma

\footnotetext{
${ }^{24}$ SILVEIRA, Paulo. A Página Violada - Da ternura à injúria na construção de livros de artista. Porto Alegre: Editora da UFRGS, 2a edição, 2008. Paulo Silveira é bacharel em Artes Plásticas e Comunicação Social, Mestre e Doutor em Artes Visuais na área de História, e Crítico da Arte pela UFRGS. Como pesquisador é referência nacional e internacional nas pesquisas sobre "Livro de Artista".
} 
boa história para contar. Ademais, comecei a observar, empiricamente, a recepção das pessoas à obra. Invariavelmente, entre leigos, especialistas ou leitores, a recepção estética sobrepunha-se à recepção científica ou literária. Conheço poucas pessoas, dentro do círculo de interesse mais stricto, que realmente o tenham lido. A relação estabelecida costuma ser predominantemente visual, e não literária ou conceitual. Tal observação reforçava minha própria percepção.

A premissa inicial era: se, por um lado, semelhante aos notáveis manuscritos medievais iluminados, tal publicação revigora o livro como obra rara, por outro lado o processo de criação da obra rompe com o paradigma da feitura do livro através de um processo colaborativo e especializado em vigor desde aquela época, no qual, tradicionalmente, o autor escreve textos, não produz livros. Essa mudança de paradigma veio a ser um dos principais pressupostos do campo do livro de artista que recolocou na história o livro como obra de arte. Evidente que a obra em questão, no rigor do sentido strictu, não encontra correspondência com o objeto específico que se inscreve a partir da arte conceitual, da mesma forma que não é de fato um manuscrito medieval. Então como conceituá-lo a fim de circunscrevê-lo? A propósito de uma definiç̧ão contundente, esta seria a de um livro raro $^{25}$, e acreditávamos, desde então, que assim deveria ser compreendido. Tal premissa que inicialmente colocou-se como um norte tornou-se, à medida que a pesquisa prosseguia, o conceito central, pois, além de circunscrever o livro em questão, é o que fundamenta, como veremos, o livro como obra de arte.

No dicionário da língua portuguesa Aurélio, raro significa aquilo "de que há pouco; que não abunda; que é pouco frequente; incomum, invulgar, extraordinário". O conceito aplicado à categoria livro, segundo as autoras do Dicionário do Livro $^{26}$, Maria Isabel Faria e Maria da Graça Pericão, pode ser apresentado, em linhas gerais, como o livro que seja "detentor de alguma particularidade especial (conteúdo, papel, ilustrações) ou por já serem conhecidos poucos exemplares".

\footnotetext{
${ }^{25} \mathrm{~A}$ fim de identificar a obra que seja rara, preciosa e/ou única, devem-se considerar os seguintes tópicos: limite histórico, aspectos bibliográficos, valor cultural, pesquisa bibliográfica e características do exemplar. Tal conceituação e critérios de parametrização serão apresentados no segundo capítulo desta dissertação.

${ }^{26}$ FARIA e PERICÃO, Maria Isabel e Maria das Graças. Dicionário do Livro. São Paulo: Editora Almedina, 1a edição, 2001. (p 209)
} 
Isso era tudo o que havia inicialmente: minha visada subjetiva à obra, a diretriz de um conceito e um esboço que, todavia, não era claro para a maioria das pessoas (salvo exceções). Sentia-me, de saída, ante dois problemas:

1. Na contemporaneidade, os livros são considerados, pelo senso comum, meros suportes de informação; o valor econômico e cultural agregado ao livro no contexto sociocultural do século XXI, em geral, é tão baixo que causa perplexidade, a ponto de Martyn Lyons em sua obra Livro, uma história viva (2011), equipará-lo ao valor atribuído a outros objetos de consumo cotidiano, como o sabão e as batatas. Conforme ele diz, além do valor econômico e cultural, o livro "perdeu sua aura mágica”. Aliás, atualmente, pouco se sabe do grande potencial plástico oferecido pela coisa livro, tampouco sobre suas contribuições e entrelaces para com a história da arte.

2. Jung não era um artista. A questão aparentemente supérflua e superada no âmbito da arte contemporânea jaz implícita, suscita controvérsias, engendra resistências; e, atreladas a ela, as indagações: afinal o que é ser ou não ser um artista frente à perspectiva contemporânea de campo expandido $^{27}$, por exemplo? O que se mostra preponderante para tal status? A escolha do sujeito? A chancela do sistema? Qual a autonomia da obra per se? São questões intrínsecas que se encontram em aberto.

O desafio que se colocava era: no contexto sociocultural do século XXI, segundo o qual, mediamente, um livro tem o mesmo valor agregado que um saco de batatas, e no qual o conceito de livro como obra de arte fora relegado a uma arte menor, como pode um exemplar que, todavia, não fora produzido por um artista (aquele que tradicionalmente possui tal prorrogativa) qualificar-se como obra de arte?

A primeira questão detinha a primazia, afinal meu protagonista era o livro, representado neste ato especificamente pelo O Livro Vermelho. As demais

\footnotetext{
${ }^{27}$ O conceito de campo expandido, formulado por Rosalind Krauss para definir uma nova práxis a partir do transbordamento artístico para além dos limites circunscritos, que permite composições complexas entre diferentes materiais, suportes, recursos e linguagens.
} 
questões interrelacionadas seriam contempladas naturalmente à medida que a própria história as colocasse em cena. Confrontá-las diretamente tornaria nosso campo sobremaneira expandido, visto que o mesmo já se apresentava naturalmente interdisciplinar. Devido a isso, aos muitos fios que o atravessavam, inicialmente tive dificuldade em delimitá-lo; percebia muitas relações e não sabia como e por onde puxar o fio condutor que afinal guiaria a pesquisa, tornando-a precisa. Até que encontrei uma referência que lançou luz ao meu propósito, apontando para a obra Que É Livro Raro? de Ana Pinheiro Machado ${ }^{28}$. Ao lê-lo, encontrei fundamento teórico para minhas ideias, e a pesquisa finalmente configurou-se da seguinte forma:

\section{Capítulo 1. A poética d'O Livro Vermelho de C. G. Jung - história, ética e estética}

No capítulo inicial apresenta-se em primeiro momento o contexto histórico e biográfico no qual se deu a gênese da obra, pois um recorte leviano que desconsiderasse aspectos essenciais de sua biografia não daria conta de circunscrever a matéria, sobretudo porque a elaboração do livro em questão dá-se como caminho e resposta a uma crise de ordem pessoal contextualizada no âmbito profissional. São também apresentadas, sucintamente, as pesquisas e ideias iniciais de Jung à luz dos desafios impostos na época em que foram elaboradas, pois foi por meio de tal caldo de cultivo que suas premissas científicas articularam-se com seu processo criativo. Na sequência são apresentados mais especificamente o processo de criação e elaboração do livro e a percepção do próprio Jung à ética e estética que, em última análise, constituíram sua poética, assim como as influências e construção da expertise autodidata do autor para cumprir com o propósito de elaborar o que viria a ser seu livro precioso. E, por fim, apresentamos O Livro Vermelho - sua estrutura formal, pinturas, iluminuras, linguagem e conteúdo -, e a forma como se deu, décadas depois, a edição, publicação e recepção da obra atrelada às questões que ela suscita.

\footnotetext{
${ }^{28}$ PINHEIRO, Ana V. T. da Paz. Que É Livro Raro? Uma metodologia para o estabelecimento de critérios de raridade bibliográfica. Rio de Janeiro: Presença, 1989.
} 


\section{Capítulo 2. O livro como obra de arte - contexto histórico e contemporâneo}

No segundo capítulo é apresentado o cenário contemporâneo do qual a obra emerge, e a desvalia do livro em tal esfera, diante do que é necessário - a fim de compreender os pressupostos que qualificam o livro como obra de arte resgatar sua história e interfaces com a história da arte, desde as origens consanguíneas de imagens e letras, até a evolução por meio de toda espécie de material que habitou a ideia de livro. Com isso, circunscrevemos os conceitos de raro, precioso e único por meio dos quais um livro pode ser validado como obra de arte. Apresentamos, também, como as obras consideradas raras são contempladas pelas políticas públicas de preservação de patrimônio cultural, passando a figurar, independentemente de sua aparência ou estilo, na categoria de obra de arte. Por fim, analisamos as aproximações e especificidades entre livros raros e livros de artista, que terminam, em geral, por circunscrever o livro de artista - que detém a priori o status de obra de arte - também como livro raro.

\section{Capítulo 3. Manuscritos medievais iluminados - o livro raro que habita nosso imaginário}

No terceiro capítulo apresentamos o manuscrito medieval iluminado, nossa principal referência de livro raro, sendo ainda o modelo que inspirou Jung na elaboração de seu Livro Vermelho. Sua importância na história é grande, sendo vários os motivos: foi por meio de seu design que o livro adquiriu sua melhor forma, estrutura e valor simbólico e cultural; durante muitos séculos deteve o papel de único disseminador do pensamento ocidental; os materiais empregados em sua constituição abriram campo para a arte das iluminuras, que se transforma em verdadeira pintura, e dá, mesmo, nascimento à pintura moderna ${ }^{29}$. Procuramos mostrar aqui, contextualizando sua evolução e declínio, de que modo as iluminuras caracterizam sobremaneira os livros raros, mas também como, indiretamente, representam a semente que germinou na arte moderna (como

\footnotetext{
29 MARTINS, Wilson. A palavra escrita: história do livro, da imprensa e da biblioteca. São Paulo: Anhembi, 1957 ( 112 ). Wilson Martins é crítico literário e autor de vários livros.
} 
veremos no próximo capítulo) os primeiros livre de peintre, livre d'art e livre d'artist. Considerando sua origem conforme apresentada no capítulo anterior, a iluminura mostra-se como o principal nexo na interface da história do livro com a história da arte

\section{Capítulo 4. Livro de/do artista - A nova arte de fazer livros}

No quarto capítulo apresentamos inicialmente algumas considerações de campo a fim de esclarecer que nossa abordagem se faz especificamente em seu sentido lato, ou seja, como um campo expandido de atuação artística e, simultaneamente, como o produto desse campo, bem diverso do que se apresenta em seu sentido stricto, quando é compreendida a partir das experiências conceituais dos anos de 1960, e, portanto, com características bem específicas. Procuramos mostrar, a partir de uma digressão, que com o advento da imprensa por volta de 1450 e o início da produção industrial do livro a partir de 1801, a arte no livro foi diminuindo progressivamente e sendo substituída pela ilustração, que, embora tenha suas raízes nas iluminuras medievais, adquiriu certo didatismo, passando ainda por um processo de massificação, em face do qual alguns anos depois, logo no início do século XX, grandes pintores do modernismo - dentre os quais Toulouse-Lautrec, Matisse, Miró, Chagall, Rouault, Max Ernest e Picasso -, por iniciativa sobretudo de editores franceses, passaram a trabalhar no livro. Assim inaugura-se no âmbito da arte moderna o livre d'art ou o livre d'artiste. Constatamos a maneira pela qual o artista apropriando-se do livro rompe com a tradição vigente e inaugura uma nova arte de fazer $\operatorname{livros}^{30}$, por meio da qual o escritor não escreve textos, e, sim, faz os livros. O livro então, através da apropriação do artista, reconquista seu espaço no território da arte, mostrando-se ainda como campo experiencial de excelência aos processos de criação e seus registros. Por meio de tal trajetória, do livro impresso ao livro de artista, mostramos ainda de que forma o campo da gravura, através das demandas de produção do livro impresso, conquistou autonomia como categoria artística, realçando a interface da história do livro com a história da arte.

\footnotetext{
${ }^{30}$ CARRIÓN, op. cit. (2011)
} 


\section{Considerações Finais}

Considerando que a pesquisa foi estruturada à moda oriental, segundo a qual o tema central é apresentado em primeiro plano, evidenciando a importância do assunto e colocando em pauta o que se mostra mais relevante, é importante esclarecer que as devidas tessituras e aproximações entre os modelos apresentados como referências de livros que transitam na categoria de obra de arte serão articuladas nas considerações finais. Essa estruturação diversa do modelo acadêmico tradicional visa atender a dois propósitos: apresentar a pesquisa da forma como ela se processou, e, em paralelo, destacar a interface da história do livro com a história da arte a fim de resgatar seu potencial plástico. Acreditamos ser possível dessa forma, demonstrar a raridade d'O Livro Vermelho e aproveitar a oportunidade, como dito por Yves Peiyré em seu livro Peinture et Poésie - le dialogue par le livre 1874-2000, de ampliar a esfera restrita na qual o livro ficou limitado como se fora uma arte menor ${ }^{31}$, para que se reconheça nele todo o seu valor.

Com isso esperamos ter a oportunidade, conforme dito por Yves Peiyré em seu livro Peinture et Poésie - le dialogue par le livre 1874-2000, de ampliar a esfera restrita na qual o livro ficou limitado como se fora uma arte menor ${ }^{32}$, e reconhecer nele todo o seu potencial.

Eu tive o prazer de arrancar uma parte da história (como arte) do livro da esfera restrita de uma arte menor para colocá-la na clareza da expressão, da criação, atestando que, no espaço de nossa temporalidade, duas artes maiores (pintura e poesia) reconhecem-se mutuamente no livro e através dele ${ }^{33}$.

\footnotetext{
${ }^{31}$ PEYRE, YVES. Peinture et Poésie - le dialogue par le livre 1874-2000. Paris: Editions Gallimard, 2001. (p 12) A conotação de "arte menor" dada por Peyré refere-se ao contexto de desvalia, e não ao conceito de arte menor quando, na Idade Média, designava a arte realizada em objetos pequenos e portáteis, como: livros, joias, punhais, espadas etc. 


\section{A POÉTICA D’O LIVRO VERMELHO DE C. G. JUNG - História, ética e estética}

Os anos durante os quais me detive nessas imagens interiores constituíram a época mais importante da minha vida. Neles todas as coisas essenciais se decidiram. Foi então que tudo teve início, e os detalhes posteriores foram apenas complementos e elucidações. Toda minha atividade ulterior consistiu em elaborar o que jorrava do inconsciente naqueles anos e que inicialmente me inundara: era a matéria-prima para a obra de uma vida inteira ${ }^{34}$.

\subsection{Contexto histórico}

A psiquiatria foi o ponto de partida de C. G. Jung e objeto constante de seu interesse $^{35}$; todavia, seus horizontes ampliaram-se consideravelmente, tornando-se também psicanalista. Não satisfeito, no entanto, com suas premissas, consolidou seu trabalho pelo viés da psicologia, fundando uma nova escola. Seus interesses e ideias estenderam-se a diversos campos do conhecimento; todavia, pouco se conhecia sobre o papel fundamental que a arte tivera em sua vida, sobretudo na articulação que se deu entre o processo de criação de seu $O$ Livro Vermelho e a elaboração de sua literatura científica. Para compreendê-lo faz-se necessário conhecer minimamente os desafios e desatinos da psiquiatria daquele tempo, e a evolução de suas pesquisas e ideias à luz da época em que foram elaboradas, pois

\footnotetext{
${ }^{34}$ JUNG, op. cit. Epígrafe, 2017.

${ }^{35}$ SILVEIRA, Nise. Imagens do Inconsciente. Rio de Janeiro: Editorial Alhambra, 1ạedição, 1981. (p 92) Médica psiquiatra brasileira reconhecida mundialmente por sua contribuição à psiquiatria. Revolucionou o tratamento mental no Brasil, dedicando sua vida ao trabalho com doentes mentais, e, manifestando-se radicalmente contra as formas que julgava serem agressivas em tratamentos de sua época, tais como o confinamento em hospitais psiquiátricos. Nise da Silveira estudou no "Instituto Carl Gustav Jung", lá recebeu supervisão em psicanálise de Marie-Louise Von Franz, assistente de Jung.
} 
sua vida e obra estão de tal forma associadas ${ }^{36}$ que não é possível circunscrever tal livro como se fora algo à parte, dissociado de sua biografia.

Carl Gustav Jung nasceu em 1875 no Lago de Constança, em Kesswil, uma comuna da Suíça onde atualmente vivem cerca de 900 habitantes. Em 1900, aos 25 anos, formou-se médico na Universidade da Basileia, e já no mesmo ano ocupou o posto de segundo assistente no famoso Burghölzli, hospital psiquiátrico de Zurique, no qual processou-se, no início do século, excepcional renovação no campo da psiquiatria ${ }^{37}$. Promovido rapidamente, em 1902 ocupou a posição de primeiro assistente. Em 1905 conquista o cargo de chefe de clínica, segundo posto da hierarquia hospitalar ${ }^{38}$. Eugen Bleuler - conhecido por nomear de esquizofrenia (das raízes gregas schizo [dividida] e phrene [mente] à então demência precoce (dementia praecox), devido à compreensão de que não se tratava de uma demência e que tampouco era exclusiva dos jovens - fora seu diretor $^{39}$. Bleuler, não satisfeito com a descrição dos sintomas orgânicos e funcionais reducionistas da psiquiatria, procurou, através de pesquisas de campo, fundamentar uma base psicológica que pudesse ser articulada aos seus protocolos. Sua contribuição foi inestimável, e o Burghölzli tornou-se hospital psiquiátrico de referência ${ }^{40}$.

Jung, compartilhando das mesmas ideias que Bleuler, lançou-se junto a outros colegas como seu colaborador no campo da experimentação do associacionismo ou associação de ideias, teoria predominante na psicologia da época $^{41}$. Acontece que no decurso da experiência, ocorriam perturbações - o tempo de reação variava, o examinado hesitava, ria, corava, transpirava - que, dantes desprezadas e interpretadas pelos psicólogos como ocorrências incômodas, despertaram a atenção de Jung, pois, como Nise da Silveira comenta, ele não

\footnotetext{
${ }^{36}$ Sonu Shamdasani em seu livro Jung - Uma Biografia em Livros, conta a vida e obra de Jung via o acervo que se fora constituindo, pois seus livros contextualizam todo o percurso de seu pensamento e construção de sua epistemologia, podendo ser considerados, assim, como "marcos do percurso".

${ }^{37}$ SILVEIRA, Nise, op. cit. (1981, p 92)

38 Idem.

39 Idem.

40 Idem.

${ }^{41}$ Idem.
} 
poderia ser um mero executante de teste, seu espírito estava atento e apreendendo o que acontecia:

As perturbações manifestadas no curso das experiências de associações indicavam que a palavra indutora havia atingido algum conteúdo afetivo oculto no íntimo do examinado, isto é, no inconsciente. Esses conteúdos seriam "complexos de ideias dotadas de forte carga afetiva". Jung denominou-os "complexos afetivos", ou simplesmente "complexos"42.

A conceituação de complexo atrelada à técnica para detectá-lo advinda de tal experiência foi a primeira grande contribuição à psicologia moderna ${ }^{43}$, consagrando "a reputação de Jung como uma das estrelas ascendentes da psiquiatria $^{44, .}$. Em 1906 ele publica Estudos sobre associações; a seguir, em 1907, Psicanálise e Experiências Associativas, no qual demonstra com exemplos práticos a conexão da psicanálise com as experiências associativas ${ }^{45}$. Segundo Nise da Silveira (1981), a obra demonstrava a possibilidade de o inconsciente ser explorado experimentalmente. Prosseguindo nesse campo de investigação, o livro Psicologia da Demência Precoce ${ }^{46}$ (1906-1907) traz a união entre observação clínica e experimentação, por meio da qual ele procura demonstrar a inteligibilidade das formações delirantes ${ }^{47}$, defendendo a tese de que, na demência precoce (esquizofrenia), todos os sintomas poderão ser compreendidos psicologicamente, pois, “apesar de absurdos, incongruentes, os delírios encerram significações, como também os neologismos, gestos e estereotipias não são vazios de sentido ${ }^{48}$, . Espirituosamente, Nise comenta:

Shakespeare já sabia que os delírios têm sentido. Aludindo aos desvairados discursos de Hamlet. Polonius diz: "Desvario, sim, mas tem seu método (Hamlet, ato II, cena ii)". Mas naturalmente os homens de ciência nunca escutam os poetas. E

\footnotetext{
42 Ibid. (p 93)

${ }^{43}$ SILVEIRA, Nise. Jung: vida e obra. São Paulo: Paz e Terra, 2011. (p 14)

${ }^{44}$ JUNG, op. cit. In Introdução por Sonu Shamdasani. (2017, p 9)

${ }^{45}$ Idem.

${ }^{46}$ A. A. Brill, freudiano ortodoxo, tradutor da edição inglesa de Psicologia da Demência Precoce, classifica o livro como "pedra angular da moderna psiquiatria interpretativa". In Imagens do Inconsciente de Nise da Silveira. (1981, p 94)

${ }^{47}$ JUNG, op. cit. In Introdução por Sonu Shamdasani. (2017, p 9)

${ }^{48}$ SILVEIRA, op. cit. (1981, p 94)
} 
no começo do século resistiam, como ainda hoje, na maioria, resistem em admitir base psicológica para as psicoses ${ }^{49}$.

Esse não foi o caso de Jung, ao contrário. Para Nise: foi ele quem "assumiu a tarefa nada fácil de abrir os caminhos da psiquiatria interpretativa ${ }^{50 "}$. Nesse processo, a leitura de A Interpretação dos Sonhos (1900) de Freud contribuiu com a evolução de sua pesquisa, pois confirmava e complementava seus pressupostos ${ }^{51}$. O que mais o interessava dizia respeito à utilização no domínio do sonho da noção do "mecanismo de recalque", emprestada à psicologia das neuroses, pois em suas experiências com associação de ideias, frequentemente deparava-se com tais recalques, e o método de análise e interpretação dos sonhos proposto por Freud lançava luz à sua compreensão das formas de expressão dos esquizofrênicos, abrindo-lhe um novo campo de pesquisa ${ }^{52}$. O resultado exposto no último livro foi justamente a ponte de contato entre ele e Freud, e, em 1906, tem início a comunicação entre ambos. Freud convida-o à sua casa em Viena, e o encontro, tornado célebre na literatura devido às 13 horas de conversação ininterrupta entre os atores, marca o início de uma amizade que se mostra cara e colaborativa aos dois, sobretudo por conta do interesse em comum na psicogênese das desordens mentais e na psicoterapia ${ }^{53}$.

O propósito de Jung consistia em: "formular uma psicoterapia científica baseada na nova psicologia e, por sua vez, sustentar a psicologia na investigação clínica profunda das vidas individuais ${ }^{54,}$. O problema que ocupava em primeiro plano o seu interesse e que motivava suas pesquisas era: "O que se passa no espírito do doente mental? ${ }^{55}$ ". Para ele, a tarefa da psiquiatria deveria basear-se na compreensão do que se passava no interior do doente; entretanto, o ensino e a prática psiquiátrica abstraíam-se de sua personalidade como se essa não existira, e

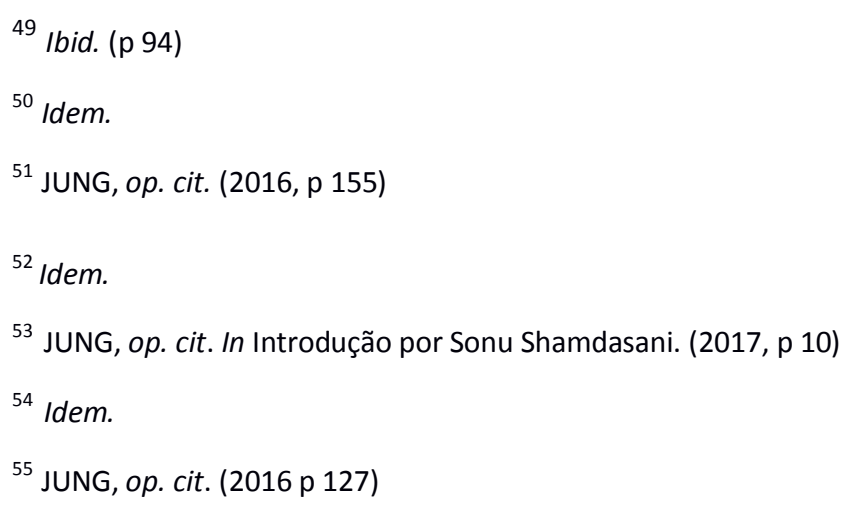


satisfazia-se com a descrição dos sintomas, diagnósticos e dados estatísticos ${ }^{56}$. Uma vez rotulados como "patológicos", pareciam suficientemente caracterizados $^{57}$ - os casos eram então encerrados (e confinados os doentes!). Ou seja, embora tais dados fossem necessários para oferecer certa orientação, não ajudavam o paciente ${ }^{58}$. Verdade é que a tal psicologia do doente mental não existia, ou não desempenhava nenhum papel ${ }^{59}$. Para Jung:

Em muitos casos psiquiátricos, o doente tem uma história que não é contada e que, em geral, ninguém conhece. Para mim, a verdadeira terapia só começa depois de examinada a história pessoal. Essa representa o segredo do paciente, segredo que o desesperou. Ao mesmo tempo encerra a chave do tratamento. É, pois, indispensável que o médico saiba descobri-la. Ele deve propor perguntas que digam respeito ao homem em sua totalidade e não limitar-se aos sintomas. Na maioria dos casos, não é suficiente explorar o material consciente ${ }^{60}$.

Visto de fora, só se manifesta no doente mental a trágica destruição de que é vítima; raramente aparece a vida, o lado da alma que não está voltado para nós ${ }^{61}$.

Analisando seus doentes e seus destinos, compreendeu que as ideias de perseguição e alucinações formavam-se em torno de um núcleo significativo, "no fundo, há os dramas de uma vida, de uma esperança, de um desejo; se não lhes compreendermos o sentido, é uma falha nossa ${ }^{62 \%}$. E nessas circunstâncias compreendeu pela primeira vez que "na psicose jaz e se oculta uma psicologia geral da personalidade ${ }^{63}$ ". Tal perspectiva atualmente pode nos parecer óbvia embora lamentavelmente se constate que a velha decrépita psiquiatria ainda reine em muitos asilos -, entretanto, naquele contexto histórico, para Jung ${ }^{64}$, o insight

\footnotetext{
${ }^{56}$ Idem.

${ }^{57}$ Ibid. (2016 p 155)

58 Ibid. (2016 p 135)

59 Ibid. (2016 p 127)

60 Ibid. (2016 p 129)

61 Ibid. (2016 p 139)

62 Ibid. (2016 p 138)

63 Idem.

64 Idem.
} 
que o levara a tal compreensão configurou-se como poderosa revelação, pois até então os psicóticos eram categoricamente alienados de qualquer sentido ou razão. Anos depois, em suas Memórias ${ }^{65}$, ele comenta:

Sempre me espantei constatando o tempo que foi necessário para que a psiquiatria se detivesse no conteúdo das psicoses. Nunca se cogitara acerca das fantasias dos doentes: por que, por exemplo, um doente julgava-se perseguido pelos jesuítas, outro pensava que os judeus queriam envenená-lo e um terceiro sentia-se perseguido pela polícia ${ }^{66}$ ?

A psiquiatria apreendia a mania de perseguição genericamente, como sintoma. O conteúdo das fantasias apenas chancelava a loucura. No momento em que Jung entende que há um significado subjacente que dá sentido às fantasias psicóticas, e que, portanto, tais fantasias devem ser levadas a sério, ele objetiva a realidade da psique. Isso foi o que podemos considerar o ponto de mutação por meio do qual houve uma quebra de paradigmas abrindo espaço para outra abordagem na psiquiatria, e servindo de fomento a uma nova psicologia.

"Embora estejamos ainda longe de conseguir explicar todos os entricamentos daquele mundo obscuro, podemos afirmar com segurança completa que na demência precoce não existe sintoma algum sem base psicológica, sem significação. Mesmo as coisas mais absurdas são símbolos de pensamento não só compreensíveis em termos humanos, mas que habitam também o íntimo de todos nós. Na loucura nada se descobre de novo ou desconhecido: estamos olhando os fundamentos de nosso próprio ser, a matriz dos problemas nos quais nos achamos todos engajados ${ }^{67}$.

O engajamento com a qual Jung encarou a natureza do conteúdo psicótico proporcionou o lastro para a elaboração das premissas de sua psicologia. Suas pesquisas iniciais junto a outras observações empíricas foram o caldo de cultivo para fomento do conceito de inconsciente coletivo ${ }^{68}-$ um dos principais pilares da epistemologia e psicologia junguianas - e demais conceitos conexos. Eram crescentes, todavia, o desencanto com as limitações dos métodos experimentais e estatísticos na psicologia e na psiquiatria, e terminam por provocar, após um

\footnotetext{
65 JUNG, op. cit. (2016)

${ }^{66}$ Idem.

67 SILVEIRA, op. cit. (Jung apud Nise, 1981, p 94)

68 Ibid. (1982, p 97)
} 
período de intensa atividade política e institucional, seu afastamento. Suas pesquisas prosseguem no lastro da mitologia, folclore e religião, pois, na sua concepção, uma psicologia da esquizofrenia precisaria ser capaz de lidar com os temas míticos, por meio dos quais os pensamentos simbólicos costumam se expressar.

O ano de 1913 mostrou-se decisivo à vida de Jung e sua obra, pois sobreveio um período de indefinições e crise; todavia, como veremos, a ruptura com os paradigmas anteriores abriu espaço para que a semente criativa ${ }^{69}$ pudesse germinar.

É a crise, que vem do grego Krisis, cujo significado é separação, avaliação, e no latim era usado na medicina antiga referindo-se ao momento decisivo da doença, onde haveria um desfecho, ou a cura ou a morte. É o turning point, o momento em que se percebe que é preciso acontecer algo, onde "cada decisão que se toma representa assim um ponto de partida, num processo de transformação que está sempre recriando o impulso que o criou". Fayga Ostrower complementa dizendo que "a cada decisão algo é deixado para trás e a possibilidade de algo novo permanece latente, à espera de sua objetivação" 70 .

No ano anterior dera-se a publicação de Metamorfoses e símbolos da libido $^{71}$ no qual ele expõe publicamente suas concepções, muito das quais vai de encontro à epistemologia freudiana, e, ao contestar a natureza da libido como essencialmente sexual, seu posicionamento divergente das ideias de Freud consolida-se.

Apesar de divergências abertas ou latentes, os anos de colaboração estreita (1907-1912) entre Freud e Jung, foram, sem dúvida, muito fecundos à psicanálise. $\mathrm{O}$ desentendimento decisivo, porém, acabou surgindo, foi provocado pelo conceito

\footnotetext{
${ }^{69}$ Esse termo é empregado por Nise da Silveira quando ela diz que a psicologia junguiana tem por meta não só a dissolução dos conflitos, mas favorecer as "sementes criativas" inerentes ao ser. Consideramos que a elaboração ética e estética de Jung para com os conteúdos do inconsciente, que deram origem ao LV, deuse na ativação dessa "semente criativa". In Imagens do Inconsciente. Rio de Janeiro: Editorial Alhambra, 1981. (p 102)

70 MORAES, Eliana. Pensando a Arteterapia. Divino de São Lourenço: Semente Editorial, 2018 (Resende apud Moraes, 2018, pp 166-167) Eliana Moraes é psicóloga e arteteraputa com dois livros publicados, ambos pela Semente Editorial.

71 Posteriormente Jung anuncia formalmente essa obra como a que traz a elaboração do conceito de inconsciente coletivo. O Livro Vermelho por C. G. Jung. In Introdução por Sonu Shamdasani. (2017, p 12)
} 
de libido, apresentado de maneira global, por Jung em Metamorfoses e Símbolos da Libido ${ }^{72}$.

Ciente de que o dogmatismo de Freud o tornara impermeável a inovações ou ideologias conflitantes com as suas próprias, já esperava por tal rompimento. Face à matéria, Jung defendeu um conceito novo e mais abrangente, apresentado de maneira geral como energia psíquica ${ }^{73}$. Na concepção freudiana, a causa dos recalques estaria, via de regra, fundamentada na sexualidade, e Jung discordava de tal pressuposto, considerando-o insatisfatório e reducionista, pois não atribuía à sexualidade o universalismo psicológico creditado por Freud ${ }^{74}$. Todavia, com visão crítica, ao mesmo tempo em que distingue suas concepções e as defende, reconhece o valor da obra realizada por Freud, pois, o grande mérito e a bravura com que Freud conseguira provar empiricamente a existência de uma psique inconsciente - que dantes fora apenas um postulado filosófico de Carl Gustav Carus e Eduard Von Hartmann ${ }^{75}$-, era motivo de admiração e reconhecimento. Para Jung, tal feito ofereceu um novo impulso à nossa civilização, estabelecido com a descoberta do sonho como a mais importante fonte dos processos do inconsciente a partir dos quais era possível acessar de alguma forma essa dimensão. No entanto, para Freud o inconsciente era uma espécie de depósito de vestígios ou experiências mortas, esquecidas ou recalcadas, isto é, fundamentalmente pessoais. Acontece que Jung deu-se conta empiricamente refletindo sobre a natureza de alguns dos conteúdos de seus próprios sonhos e fantasias, como também de seus pacientes, e articulando-os com suas pesquisas e

\footnotetext{
72 SILVEIRA, op. cit. (2011, p 36)

73 Basicamente, enquanto Freud atribui à libido significação exclusivamente sexual, Jung denomina libido a energia psíquica tomada num sentido amplo. Para Jung todos os fenômenos psíquicos são de natureza energética. In Jung, vida e obra por Nise da Silveira. Rio de Janeiro: Paz e Terra, 2011. (pp 37-41)

74 Ibid. (2011, p 36)

${ }^{75}$ Embora vários filósofos já tivessem apontado muito claramente o problema do lado sombrio da psique, de acordo com o próprio Jung, foi um médico que se sentiu impelido, de sua experiência científica e médica, a apontar para o inconsciente como a base essencial da psique. Este foi C. G. Carus, seguido por Eduard Von Hartmann, autor de Filosofia do Inconsciente, publicado em 1868, e discípulo de Schopenhauer. Recomendamos a leitura de The Discovery of the Unconscious de Henri F. Ellenberger (1905-1993), lançada em 1970, o livro traça uma história do conceito de inconsciente. Para os românticos, o termo "inconsciente", como afirma Ellenberger, "era o próprio fundamento do ser humano enquanto ser enraizado na vida invisível do universo e, portanto, a verdadeira ligação unindo homem com natureza" (1970 p 204).
} 
experimentações científicas - da existência de matérias transpessoais que não poderiam ser explicadas como meros vestígios pessoais, pois não apenas transcendiam tais experiências, como também revelavam-se essencialmente arcaicos, uma espécie de DNA psíquico onde se poderia encontrar toda a memória de nossa ancestralidade em estado latente. Desse modo, na psicologia junguiana o inconsciente compreende inconsciente pessoal $^{76} \mathrm{e}$ inconsciente coletivo.

O inconsciente coletivo é uma parte da psique que pode distinguir-se de um inconsciente pessoal pelo fato de que não deve sua existência à experiência pessoal, não sendo, portanto, uma aquisição pessoal. Enquanto o inconsciente é constituído essencialmente de conteúdos que já foram conscientes e, no entanto, desapareceram da consciência por já terem sido reprimidos ou esquecidos, os conteúdos do inconsciente coletivo nunca estiveram na consciência e, portanto, não foram adquiridos individualmente, mas devem sua existência apenas à hereditariedade. Enquanto o inconsciente pessoal consiste em sua maior parte de complexos, o conteúdo do inconsciente coletivo é constituído essencialmente de arquétipos ${ }^{77} .^{78}$

Jung vai afastando-se da perspectiva psicanalítica, até que, em 10 de julho de 1914, confirmando sua opinião quanto ao autoritarismo inflexível de Freud, a Associação Psicanalítica de Zurique votou a favor de sua saída por 14 votos a 1. De acordo com Shamdasani, nas atas da Associação, a justificativa para tal exclusão fundamentava-se na ortodoxia estabelecida por Freud, que impedia a pesquisa livre e independente ${ }^{79}$. Ademais, seu livro Metamorfoses e Símbolos da Libido, mal compreendido provocou extremo alarido. Décadas depois, em 1952, em prefácio a nova edição desse mesmo livro, Jung comenta que ao escrevê-lo, com 36 anos de idade, passava por uma época crítica que representava o início da

76 Essa denominação refere-se às camadas mais superficiais do inconsciente, cujas fronteiras com o inconsciente são imprecisas. Abriga diversos elementos da psique pessoal do sujeito, que, embora não estejam em conexão com o ego, influenciam os processos conscientes. Jung, vida e obra, por Nise da Silveira. Rio de Janeiro: Paz e Terra, 2011. (pp 63-64)

\footnotetext{
${ }^{77}$ O conceito de arquétipo, que constitui um correlato indispensável da ideia do inconsciente coletivo, indica a existência de determinadas formas na psique, que estão presentes em todo tempo e em todo lugar. A pesquisa mitológica denomina-as "motivos" ou "temas"; na psicologia dos primitivos elas correspondem ao conceito das représentations colectives de Levy-Brühl.

78 JUNG, C. J. Os arquétipos e o inconsciente coletivo. Petrópolis: Vozes, 4ạ edição, 2006. (p 53)

79 JUNG, op. cit. (2017, p 10)
} 
segunda metade da vida de um homem quando não raro ocorre uma metanoia, isto é, uma transformação mental ${ }^{80}$.

Depois da ruptura, sobreveio um período de incerteza interior e desorientação, no qual, segundo ele descreve, seu maior anseio consistia justamente em adquirir uma nova postura na conduta com seus pacientes, que fosse coerente com suas percepções e convicções ${ }^{81}$; no entanto, tal atuação demandava um caminho ainda a ser percorrido. "Nessa época, para dizer a verdade, não sabia mais do que Freud (...) eu me sentia flutuando, pois ainda não encontrara minha própria posição ${ }^{82}$ \%. Durante esse período de indefinições e transição, provavelmente motivado pelas suas investigações empíricas e envolvimento com tais conteúdos da psique, bem como por motivos e configurações pessoais, Jung descreve ter tido muitos sonhos e visões. Somandose ao seu estado de espírito, certamente os estudos mitológicos de então impuseram-se com certa pregnância. Segundo suas lembranças:

Parecia-me que estava vivendo num manicômio que eu mesmo tinha construído. Eu andava de lá para cá com todas essas figuras fantásticas, centauros, ninfas, sátiros, deuses e deusas, como se fossem pacientes e eu os tivesse analisando. Eu lia um mito grego ou negro como se um lunático estivesse me contando sua anamnese ${ }^{83}$.

Na busca por compreender os pensamentos simbólicos dos psicóticos e seu mito subjacente, deu-se conta de que não era capaz de perceber qual seria o seu mito pessoal, e isso lhe provocou grandes questionamentos, pois chegara à conclusão de que alguém que vivia sem um mito era "um erradicado, que não tem contato verdadeiro nem com o passado, a vida dos ancestrais (que sempre vive em seu seio), nem com a sociedade humana do presente ${ }^{84}$,.

Eu me sentia compelido a perguntar-me com toda a seriedade: "O que é o mito que você vive"? Não achei a resposta e tive que me confessar que na verdade eu não vivia nem com um mito

\footnotetext{
80 JUNG, op. cit. In Introdução por Sonu Shamdasani. (2017, p 13)

81 JUNG, op. cit. (2016, p 177)

82 Idem.

${ }^{83}$ JUNG, op. cit. In Introdução por Sonu Shamdasani. (2017, p 13)

${ }^{84}$ Ibid. (p 11)
} 
nem dentro de um mito, e sim numa nuvem insegura de possibilidades de conceitos, que eu olhava, aliás, com desconfiança crescente... Veio-me então, naturalmente, a decisão de conhecer "meu mito". E considerei isso como tarefa por excelência, pois - assim eu me dizia - como poderia prestar contas corretamente de meu fator pessoal, de minha equação pessoal, diante de meus pacientes, se nada sabia a respeito, e sendo isso, no entanto, tão fundamental para o reconhecimento do outro ${ }^{85}$

Impregnado como estava por todas essas questões, em dado momento foi tão intensamente tomado por um fluxo de imagens que emergiam de seu inconsciente, que, somado ao estado de desorientação que ele descrevera, levou-o inclusive a suspeitar de que estivesse a constelar uma psicose. No entanto, com o propósito de realizar um autoexperimento psíquico, ele se decide a confrontar tais visões, ainda que lhe pareça um absurdo total ${ }^{86}$. Esse momento, no qual Jung deixa fluir os influxos do inconsciente, e, conscientemente, sustenta tal experiência, marca a travessia pessoal designada por ele de "confronto com o inconsciente".

\footnotetext{
${ }^{85}$ Idem.

86 JUNG, op. cit. In Prefácio à edição brasileira por Léon Bonaventure (2016 p 13). Belga, doutor em Psicologia, contribuiu significativamente para a divulgação da psicologia analítica no Brasil.
} 


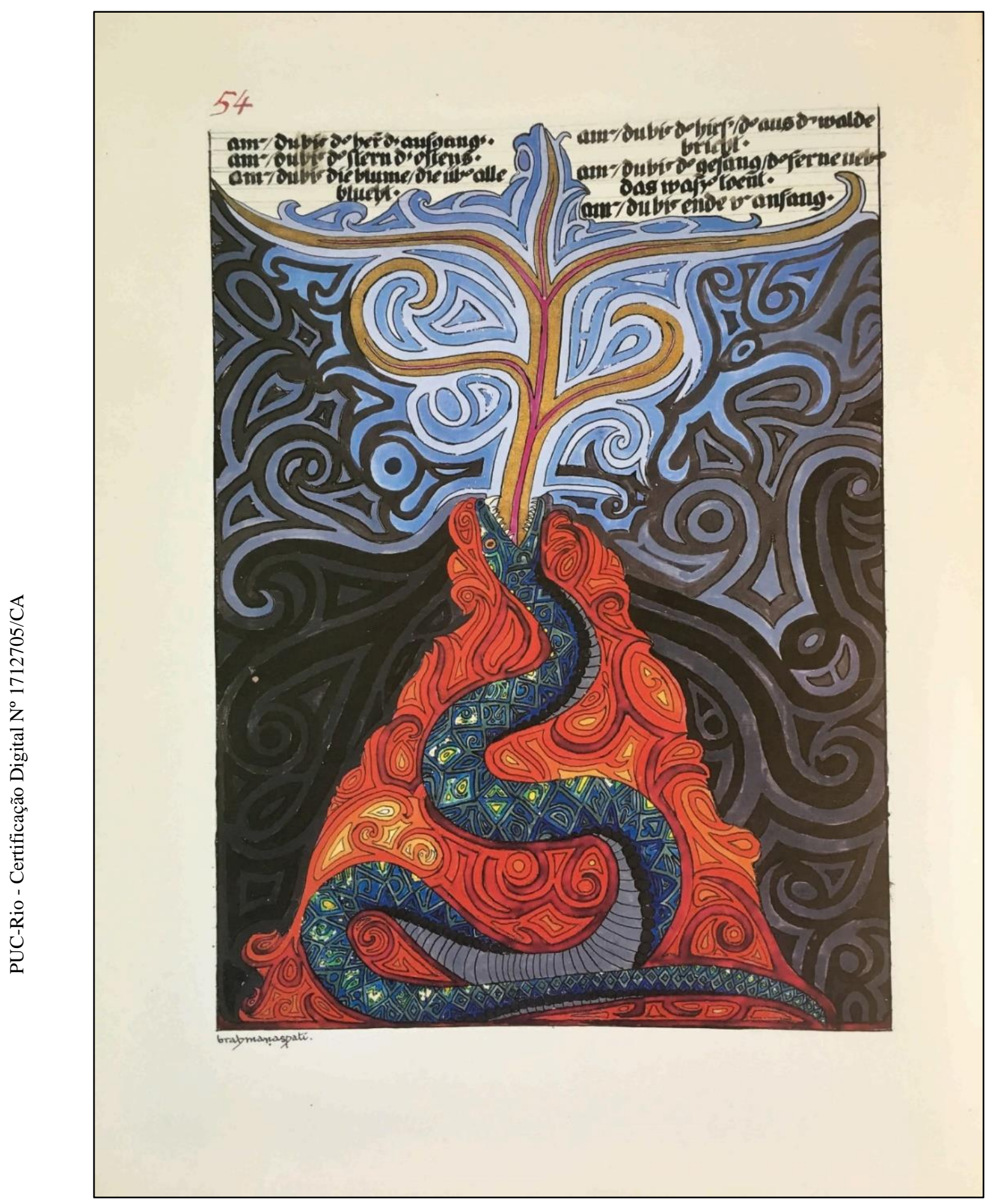

Figura 1: Ilustração "Brahmanaspati" (p 54/LV) 


\subsection{Confronto com o inconsciente}

Quando a mente está num estado alterado (diferente da consciência racional controladora do ego), é capaz de acessar impulsos da mente inconsciente (...) podem manifestar-se numa variedade de modos: pensamentos intuitivos, insights, um desejo forte de fazer alguma coisa sem saber por que, experiências espirituais e excepcionais etc. Pessoas que recebem esses impulsos podem espontaneamente expressar suas inspirações em imagens simbólicas e outras formas criativas ${ }^{87}$.

$\mathrm{O}$ autoexperimento a que se propôs consistia no enfrentamento e acolhimento de qualquer imagem que lhe surgisse - visões, sonhos, fantasias -, e ainda que lhe parecesse um total desvario; conceder-lhes voz, forma e sentido, registrando-as em diários que ele nomeou de Livros Negros ${ }^{88}$. Anteriormente já havia registrado percepções de seus estados interiores em um diário por meio de metáforas tais como "estar num deserto com um sol insuportavelmente quente (isto é, a consciência) ${ }^{89}$ "; e em algum momento ocorreu-lhe que poderia elaborar seus registros e reflexões sequencialmente. "Ele estava escrevendo material autobiográfico, mas não como uma autobiografia ${ }^{90 " ; ~ t o d a v i a, ~ S h a m d a s a n i ~}{ }^{91}$ sublinha: não se tratava de um diário de eventos e tampouco do registro de seus sonhos (embora houvesse um ou outro), e, sim, do registro de um experimento, no qual havia reflexões sobre seu estado mental e suas dificuldades em compreender suas fantasias ${ }^{92}$.

\footnotetext{
${ }^{87}$ BELLO, Susan. Pintando sua alma: método de desenvolvimento da personalidade criativa. Rio de Janeiro: Wak, 2007. (pp 25-26) Fundadora e organizadora da The Arts \& Whole Brain Learning, Susan Belo é PhD em psicologia da arte e terapia expressiva. Autora dos livros: Pintura Espontânea e Pintando Sua Alma.

88 JUNG, op. cit. In Introdução por Sonu Shamdasani. (2017, p 21)

89 Ibid. (2017, p 18)

90 Idem.

91 Ibid. (2017, p 21)

92 Idem.
} 
Desde o início concebera esse confronto com o inconsciente como uma experiência científica sobre mim mesmo em cujo resultado eu estava vitalmente interessado. (...) Foi no ano de 1913 que decidi tentar o passo decisivo - no dia 12 de dezembro. Sentado em meu escritório, considerei mais uma vez os temores que sentia (...). Eu anotava minhas fantasias na medida do possível e me esforçava também por exprimir as condições psíquicas sob as quais apareciam ${ }^{93}$.

Posteriormente, avaliando a experiência em retrospectiva, Jung descreve que seu intento era observar os influxos de seu inconsciente como se tivesse "desligado" a consciência, pois, baseando-se na observação dos sonhos, percebia a existência de uma atividade de fundo, a qual queria deixar que emergisse como possivelmente acontece ao se ingerir substâncias alucinógenas ${ }^{94}$. Percebeu que eram expressões oriundas dos processos que aconteciam no fundo do inconsciente e desenvolveu uma técnica por meio da qual estabelecia contato com elas para "chegar ao fundo do seu processo interior" e "traduzir as emoções em imagens" Deu-se conta de que ao deixá-las virem à tona e dar-lhes forma e voz, ou seja, na medida em que conseguia expressá-las, dialogar e entender-se com elas, levandoas a sério e trazendo-as para o âmbito da consciência, readquiria paz interior. Assim Jung seguiu, observando-as sem qualquer julgamento ou censura, simplesmente permitindo que aflorassem, e "mostrassem" a que vieram. Invariavelmente tinham uma história para contar, algo para reivindicar, algo a ensinar, algo a realizar, ou alguma revelação a fazer. Posteriormente, sob o conceito de imaginação ativa ${ }^{96}$, Jung aprofundou, fundamentou e incorporou metodologicamente essa forma de abordagem às fantasias e aos complexos afetivos inconscientes em sua epistemologia e práticas psicoterapêuticas ${ }^{97}$.

Dentre um misto de memórias do passado, premonições do futuro e imagens arquetípicas que, no percurso de tal experimento, emergiram em seus

\footnotetext{
93 JUNG, op. cit. (2016 pp 184)

94 JUNG, op. cit. In Introdução por Sonu Shamdasani. (2017, p 21)

95 JUNG, op. cit. In Prefácio por Ulrich Hoerni, 2017.

${ }^{96}$ Esse tema é fundamental, pois a ele vincula-se o processo de individuação, eixo central da psicologia junguiana. Ademais, sucintamente foi o processo criativo vivenciado na elaboração da matéria em exposição - confronto com o inconsciente. O tema será aprofundado na próxima seção.

${ }^{97}$ Idem.
} 
sonhos ou imaginação, para Jung foram preponderantes as lembranças afetivas de seus jogos de infância, pois com elas deu-se conta de que a vida criativa do garoto que ele fora fazia-lhe falta. Refletindo então sobre a necessidade de resgatar o contato com aquilo que ficara para trás, ele percebeu que para tal era necessário voltar-se para a criança que fora um dia e acolhê-la interiormente ${ }^{98}$, dando-lhe voz e gesto por meio da permissão de entregar-se novamente a jogos infantis ou atividades lúdicas e criativas. Passou então a dedicar algumas horas diárias a esse "brincar", inicialmente com pedras e jogos de construção. Jung descreve a dificuldade e resistência inicial que sentira a efetivamente deixar-se levar por tais atividades, contudo reconhece e sublinha sua extrema importância, pois sem que soubesse inicialmente como, por quê, ou para quê, mostrou-se determinante na elaboração de sua obra ${ }^{99}$, vindo a ser uma espécie de rite d'entrée que lhe facilitava os pensamentos e trabalhos ${ }^{100}$.

Com isso meus pensamentos tornavam-se claros e conseguia apreender de modo mais preciso as fantasias das quais até então tivera apenas um vago pressentimento. Naturalmente, eu cogitava acerca da significação de meus jogos e perguntava a mim mesmo: "Para falar a verdade, o que fazes? Constróis uma pequena colônia e o fazes como se fosse um rito". (...) Situações desse tipo repetiram-se em minha vida; sempre que me sentia bloqueado, em períodos posteriores, eu pintava ou esculpia uma pedra $^{101}$.

Naturalmente, à medida que entrava em contato com suas fantasias, além de registrá-las, passou a elaborá-las esteticamente ${ }^{102}$. Apreendeu então "o quanto era salutar, do ponto de vista terapêutico, trazer à tona as imagens que residem por trás das emoções ${ }^{103}$ ", pois ao relacionar-se com elas objetivamente, evitava as mazelas de seus efeitos negativos inconscientes, provocados por uma vida

\footnotetext{
98 Naquela época não existia ainda em terapia o processo conhecido hoje como "Resgate da criança interior", "Cura da criança interior", ou ainda, "Encontro com a criança interior", entretanto, tal processo consiste basicamente no acolhimento daquilo que representa a criança que todos fomos um dia.

99 JUNG, op. cit. (2016, p 194)

100 Ibid. (2016, p 181)

${ }^{101}$ Idem.

102 "Elaboração estética" é a maneira pela qual Jung refere-se ao processo de plasmar tais imagens, trazendo suas expressões do plano virtual para o plano material geralmente pintando-as ou através de algum processo plástico semelhante.

103 JUNG, op. cit. (2016, p 183)
} 
fragmentada ou de alguma forma privada de sua totalidade ${ }^{104}$. "A noção de que os personagens destas fantasias tinham uma realidade psicológica própria ao invés de considera-los ficções meramente subjetivas ${ }^{105 "}$ foi o grande diferencial na abordagem de Jung aos conteúdos do inconsciente, ele literalmente objetiva a realidade da psique e aceita o "irracional" como um fator psicológico digno de consideração, uma instância em nós que é capaz de enunciar coisas que não sabemos, não pensamos, e com as quais eventualmente não concordamos, mas que, no entanto, subjacentes ao limiar da consciência, têm vida própria e nos afetam.

Consciente da complexidade e profundidade da questão, tanto pelo trato objetivo com pacientes acometidos por um mar de fantasias funestas, quanto por seu confronto subjetivo, o diferencial em seu trabalho, conforme ele mesmo sublinha, foi a primazia dada à responsabilidade ética na conduta frente a tais imagens, isto é, levando-as a sério, sem negligenciá-las ou subestimá-las, trazendo-as de alguma forma do plano da mera fantasia descontrolada à consciência, e, sobretudo, procurando compreendê-las. Léon Bonaventure ${ }^{106}$ circunscreve o pleno entendimento de tal atitude ética e responsiva frente ao fenômeno, como indispensável para compreensão do caminho que Jung seguiu e deixou como legado, pois, o surgimento do novo modelo de psicoterapia, que fosse coerente com suas percepções e convicções ${ }^{107}$ como dantes ele ansiara, deuse por meio desse processo de autoexperimentação com o qual se envolveu, consistindo em uma resposta direta às questões teóricas levantadas em suas pesquisas ${ }^{108}$. Foi por meio de tal processo que começou seu trajeto essencialmente pessoal $^{109}$; nessas fantasias iniciais está contida toda sua obra, ainda que sob a forma de emoções ou imagens ${ }^{110}$. O registro do processo - um trabalho de

\footnotetext{
${ }^{104}$ Idem.

105 JUNG, op. cit. In Introdução por Sonu Shamdasani. (2017, p 50)

${ }^{106}$ JUNG, op. cit. In “Prefácio” por Leon Bonaventure (2016)

${ }^{107}$ Ibid. (2016, p 177)

108 JUNG, op. cit. In Introdução por Sonu Shamdasani. (2017, p 14)

${ }^{109}$ Idem.

${ }^{110}$ JUNG, op. cit. (2016 p 198)
} 


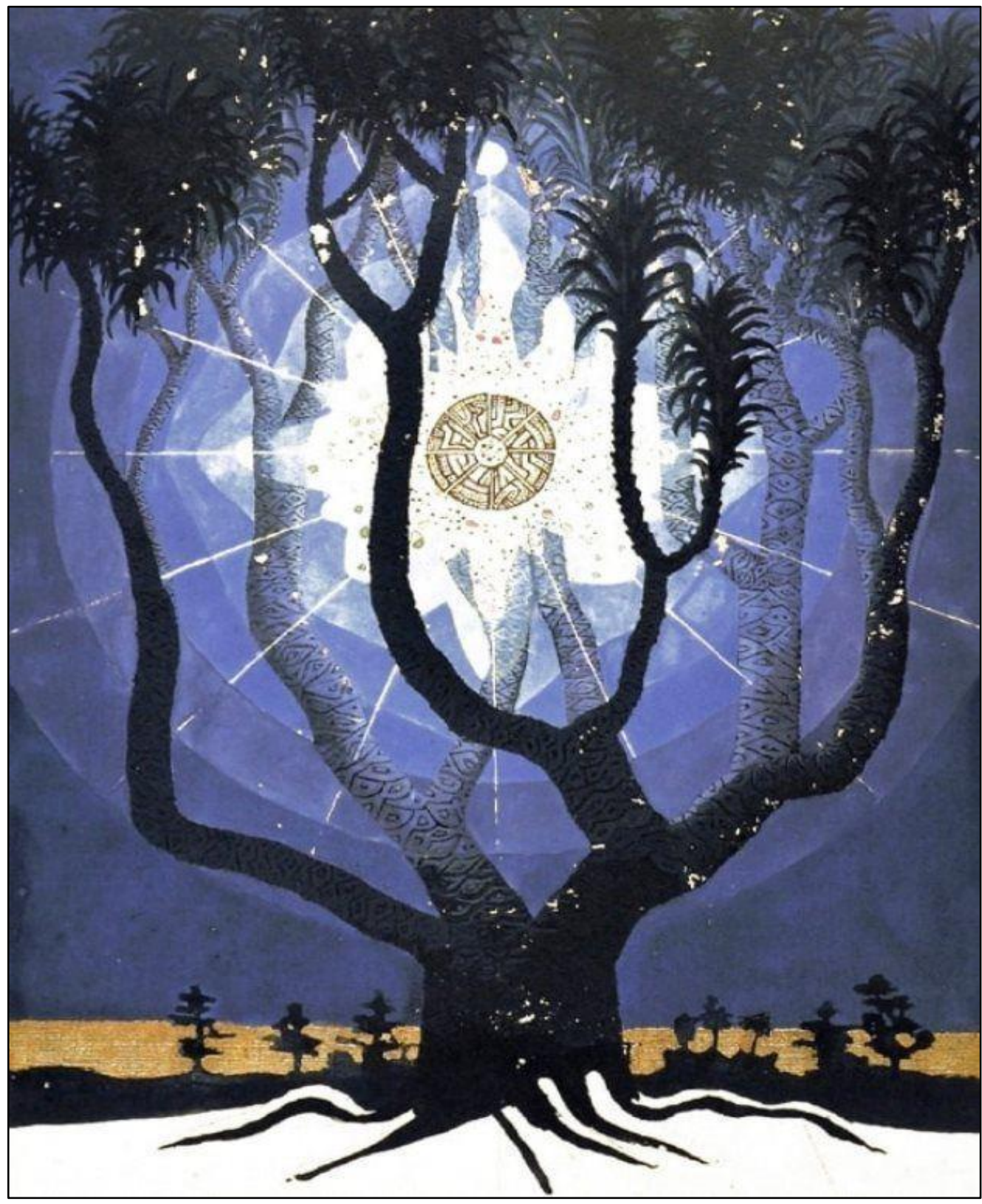

Figura 2: Ilustração sem título da (p 131 /LV )

psicologia em formato literário ${ }^{111}$ - foi o que resultou no $O$ Livro Vermelho, daí sua importância para plena compreensão de sua obra.

[...] o self, fundamento da psicologia junguiana, não é uma ideia nascida de uma reflexão, mas apresentou-se primeiro a Jung como uma realidade vivida - aliás inesperada - que o sustentou e o ajudou a colocar em ordem os elementos surgidos durante suas provações. Dispondo-se a ser ao mesmo tempo sujeito e objeto da experiência, ele chegou à vivência do self ${ }^{12}$.

\footnotetext{
111 JUNG, op. cit. In Introdução por Sonu Shamdasani. (2017, p 3)

112 Idem.
} 


\title{
1.30 processo de criação d'O Livro Vermelho
}

\begin{abstract}
Havia um céu azul, que também parecia ser o mar, coberto não por nuvens, mas por torrões marrons da terra. Parecia que os torrões estavam se desagregando e que a água azul do mar estava se tornando visivel por entre eles. Mas a água era o céu azul. Subitamente surgiu um ser alado navegando os céus, pairando à direita. Vi que era um homem velho [...]. Ele segurava um molho de quatro chaves, uma das quais ele agarrava como se estivesse para abrir uma porta. Ele tinha as asas como as de um martim-pescador com suas cores características. Como não se compreende a imagem do sonho, pintei-a para figurá-la com maior exatidão ${ }^{113}$.
\end{abstract}

No decurso de sua experiência de acolhimento e enfrentamento das fantasias e subsequentes apontamentos em diários denominados por Jung de Livros Negros, em dado momento, conforme descreve, sente necessidade de elaborar esteticamente a matéria de suas fantasias. Em Memórias ${ }^{114}$, quando descreve o aparecimento de Filemôn ${ }^{115}$, por exemplo, dá-nos uma ideia do processo que foi se configurando, e a maneira pela qual, com o intento de compreendê-lo, decide-se a pintá-lo. Aos registros iniciais foram acrescidos outros textos por meio dos quais Jung teceu comentários, reflexões ou elaborações a propósito do desdobramento e/ ou entendimento dessas experiências; copiava-os então para o Liber Novus em escrita caligráfica junto às pinturas, iniciais iluminadas, bordaduras ornamentais e margens ${ }^{116}$.

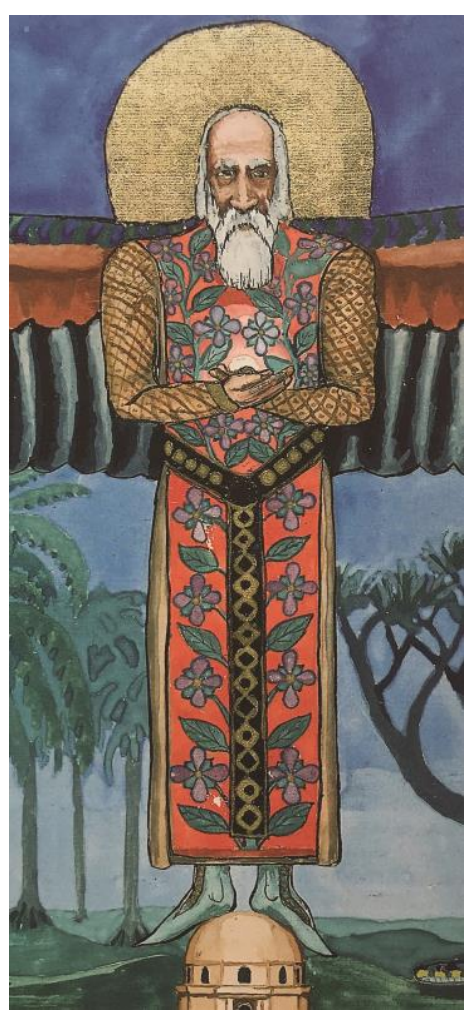

Figura 2: Filemôn Ilustração parcial (p 154 /LV)

\footnotetext{
113 JUNG, op. cit. (2016, p 188)

114 Idem.

${ }^{115}$ Idem. Segundo a descrição do autor, Filemôn era um personagem misterioso de inteligência superior com tonalidade algo gnóstica, representava o guia interior.

${ }^{116}$ JUNG, op. cit. Sonu Shamdasani in Introdução (2017 p 30)
} 
As fantasias que nessa época me vieram ao espírito foram primeiro anotadas no Livro Negro e mais tarde as transcrevi no Livro Vermelho, que ornei de imagens ${ }^{117}$.

(...) Procurei transformar cuidadosamente cada imagem, cada conteúdo, compreendendo-os racionalmente à medida do possível e, principalmente, procurei realizá-los na vida ${ }^{118}$.

Inicialmente as pinturas estão relacionadas objetivamente ao texto, no entanto, vão se tornando mais e mais simbólicas ${ }^{119}$ ou expressões em si mesmas, mas, principalmente desvelam-se como “imaginações ativas em seu próprio sentido $^{120 \text { ". Conforme a descrição de Shamdasani }}{ }^{121}$, a obra está organizada como uma iluminura medieval, caligrafada e encabeçada por uma tábua de abreviações e inserida em um in-fólio feito de pergaminho e encadernado em couro vermelho $^{122}$. Compõe-se de narrativas, diálogos, orações, sermões de cunho metafórico ou mitolgico, encantações, além das pinturas - iluminuras, iniciais historiadas, decoradas ou iluminadas, e mandalas - pintadas com guache, aquarela e têmpera ${ }^{123}$. O conteúdo, dividido em capítulos e organizado em duas partes, Liber Primus e Liber Secundus, segue fielmente a ordem cronológica dos acontecimentos imagéticos; há, além disso ${ }^{124}$, uma parte subsequente chamada Aprofundamentos, que para Shamdasani forma efetivamente o Liber Tertius do Liber Novus, sem a qual, segundo ele, não é possível compreender plenamente a

\footnotetext{
${ }^{117}$ Ibid. (2016, p 193)

${ }^{118}$ Idem.

119 Para Jung, símbolo é um termo, um nome ou mesmo uma imagem que pode ser familiar na vida cotidiana, embora possua conotações especiais além do seu significado evidente e convencional. Assim uma palavra ou imagem é simbólica quando implica alguma coisa além de seu significado manifesto e imediato, ou seja, há subjacente um aspecto "inconsciente" mais amplo, que nunca é precisamente definido ou explicado. Quando a mente explora um símbolo, é conduzida a ideias que estão fora do alcance da razão. In JUNG. C. G. O Homem e seus símbolos. Rio de Janeiro: Nova Fronteira, 2008. (p 19)

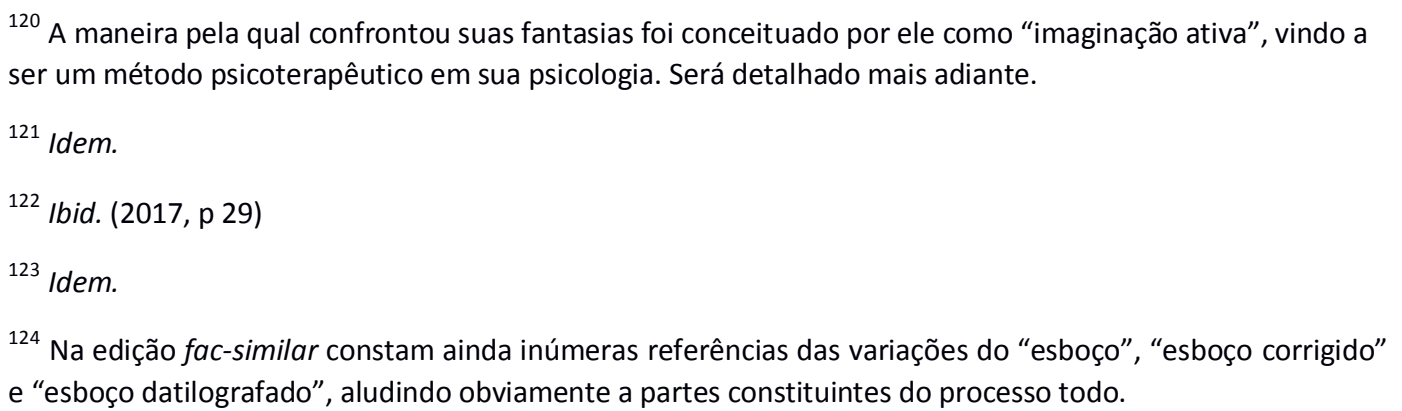


escritura $^{125}$. Seguindo a proposição de Shamdasani, a sequência completa do texto seria a seguinte ${ }^{126}$ :

Liber Primus: "O caminho daquele que virá"

Liber Secundus: "As imagens do errante"

Liber Tertius: "Aprofundamentos"

A criação e elaboração duraram 16 anos, ao longo dos quais, segundo o próprio Jung, ele trabalhou em segredo, na solidão e no silêncio ${ }^{127}$. A propósito de tal feito, em dado momento ele se questiona:

"Mas afinal, o que estou fazendo? Certamente nada disso tem a ver com ciência. Então do que se trata?" Uma voz disse em mim: "O que fazes é arte". Fiquei profundamente surpreendido, pois nunca me teria vindo ao espírito a ideia de que minhas fantasias relacionassem-se com arte. Naturalmente o que eu fazia não era ciência. Então o que poderia ser, senão arte?" ${ }^{128}$.

Tal questionamento endereçado a si próprio abre também campo à reflexão sobre o modo de proceder na ciência e na arte. No caso em questão, hoje podemos constatar, de acordo com a perspectiva sob a qual estamos apresentando O Livro Vermelho, que seu fazer, sim, era artístico, todavia, era também um fazer científico, como comprova a psicoterapia que daí se originou. Cabe trazer à pauta que já em Transformações e símbolos da libido, livro que conforme vimos inaugura a epistemologia propriamente junguiana, Jung, seguindo no lastro de William James ${ }^{129}$, diferencia e contrapõe dois tipos de pensamento: o pensamento direcionado, verbal e lógico, tipicamente exemplificado pelo pensamento científico; e o pensamento de fantasia, passivo, associativo e imagético, como se constata no pensamento criativo e no pensamento mitológico, predominantes entre os povos pré-históricos ou primitivos ${ }^{130}$. Cumpre chamar a atenção para as especificidades do processo de criação do LV, por meio do qual, ao que parece,

\footnotetext{
125 JUNG, op. cit. Sonu Shamdasani in Introdução (2017 p 41)

${ }^{126}$ Idem.

127 JUNG, op. cit. (2016, pp 198-199) Havia um conflito entre a necessidade premente de seguir esse caminho em busca de uma nova psicoterapia e a dúvida se tal obra seria aceitável ou reconhecível socialmente.

${ }^{128}$ Ibid. (2016, p 191)

129 JUNG, op. cit. Sonu Shamdasani in Introdução (2017, p 12)

${ }^{130}$ Ibid. (2017, p 20)
} 
Jung teria atuado a partir dos dois modos de pensamento descritos. Inicialmente, ao evocar em estado de alerta e de modo deliberado uma fantasia, para depois envolver-se com ela como se fora um psicodrama, registrá-la em escrita literária ou plasticamente, com o pensamento criativo, para, em seguida, proceder com os respectivos apontamentos datados nos Livros Negros, de modo a poder compreender e refletir o fenômeno psíquico vivenciado à luz da ciência, com o pensamento científico. Seguindo o processo, o intercâmbio entre os dois modos de pensar prossegue nas constantes reelaborações sobre o material produzido que acaba desdobrando-se em camadas de abordagens diversas. Portanto, no caso em questão, podemos considerar que arte e ciência caminharam de mãos dadas.

Contudo, entre ponderações e resistências quanto à natureza artística da obra, ele termina por considerar que seu intento não chegara a bom termo, porquanto não o concluíra, e nem se expressara adequadamente. Sentia ainda a necessidade de "traduzir" o que havia produzido. Concentrou-se então no que lhe era indispensável: a compreensão e elaboração de conclusões concretas a respeito dos acontecimentos apreendidos, o que acabaria por se transformar no propósito de sua vida ${ }^{131}$. Jung reconhece, todavia, que tal elaboração estética foi o caminho através do qual se deu conta do que realmente importava - a responsabilidade ética com que deveria conduzir o trato com tais imagens ${ }^{132}$. Entre a estética e a ética conduziu tal fenômeno por meio do qual deu-se a articulação entre sua experimentação psíquica e artística com seus pressupostos científicos, vindo a ser determinante para o modus operandi de sua psicologia, na qual, por fim, o trabalho criativo com as imagens oriundas do inconsciente torna-se modelar para a devida abordagem ética.

As bases de uma atitude nova perante o trabalho analítico são elaboradas a partir do Liber Novus: técnicas expressivas não verbais aparecem como importantes no processo. O trabalho com imagens, pinturas, desenhos e esculturas fica bastante valorizado a partir das experiências de Jung [...]. O trabalho com sonhos $\mathrm{e}$ imagens torna-se o centro do modelo junguiano ${ }^{133}$.

\footnotetext{
${ }^{131}$ Ibid. (2016, p 198)

${ }^{132}$ Idem.

${ }^{133}$ BOECHAT, op. cit. (2014, p 176)
} 
De que outra forma poder-se-ia acolher, confrontar, dialogar, elaborar e, sobretudo, realizar tais imagens, naturalmente virtuais e inconsistentes, não fora através da representação visual, isto é, trazendo-as do plano das ideias para o plano material? O conceito de representação visual que nos chega por meio dos sentidos (pinturas, gravuras, desenhos, fotografia etc.) interliga-se, justamente, ao domínio imaterial das imagens. A noção de imagem vincula-se intrinsicamente à representação visual, o que demanda objetivá-las e materializá-las de alguma forma. Daí se compreende a necessidade sentida por Jung de, conforme ele diz, elaborá-las esteticamente, objetivando-as para o plano material de modo que pudessem ser vistas e confrontadas. E como compreendê-las cientificamente sem o concurso de uma linguagem que não fora conceitual? A forma literária, metafórica e simbólica dá-se como resposta, integrando, no seio do livro, texto e imagem. E assim, conforme diz Fayga Ostrower ${ }^{134}$, em tais formas "entrevistas" podem-se avaliar os aspectos e os sentidos que se colocaram por meio do fenômeno, traduzindo uma ordem maior.

Criar é, basicamente, formar. É poder dar uma forma a algo novo. Em qualquer que seja o campo da atividade, trata-se, nesse "novo", de novas coerências que se estabeleçam para a mente humana. Fenômenos relacionados de modo novo e compreendidos em termos novos. $\mathrm{O}$ ato criador abrange, portanto, a capacidade de compreender, e essa, por sua vez, a de relacionar, ordenar, configurar, significar. Desde as primeiras culturas, o ser humano surge dotado de um dom singular; mais do que "homo faber", ser fazedor, o homem é um ser informador. Ele é capaz de estabelecer relacionamentos entre os múltiplos eventos que ocorram ao redor e dentro dele. Relacionando os eventos, ele se configura em sua experiência de viver e lhes dá um significado. Nas perguntas que o homem faz ou nas relações que encontra, ao agir, ao imaginar, ao sonhar, sempre o homem relaciona e forma. Nós nos movemos entre formas. [...] $\mathrm{Na}$ forma a ser dada configura-se todo um relacionamento nosso com os meios e conosco mesmos [...] esse experimentar imaginativamente com formas e meios corresponde a um traduzir na mente certas disposições, que estabeleçam uma ordem maior, da matéria, e ordem interior nossa. Indaga-se através das formas entrevistas, sobre aspectos novos nos fenômenos, ao mesmo tempo em que se procura avaliar o sentido que esses fenômenos novos podem ter para nós" ${ }^{\prime 135}$.

\footnotetext{
${ }^{134}$ OSTROWER, F. Criatividade e processos de criação. Petrópolis: Vozes, 1997 (p 34)

${ }^{135}$ Idem.
} 
Para Luigi Pareyson ${ }^{136}$, a arte estaria radicada justamente nesse processo criativo e formativo - oriundo do poien grego - segundo o qual esse "fazer" só é verdadeiramente um "formar" quando não há regras ou técnicas prefixadas, e sim quando "no próprio curso da operação inventa o modus operandi", ou seja, "concebe executando e projeta no próprio ato que realiza".

Embora Jung tenha tido suas razões para resistir e recusar a aceitar a natureza artística de seu Liber Novus, percebe-se claramente que seu lugar de fala sobre teorias da arte tem como fonte crítica sua própria experiência ${ }^{137}$, por meio da qual é capaz de falar, como criador e como psicólogo, do fenômeno psíquico que se dá no campo da criação. O ensaio "A relação da psicologia analítica com a obra de arte poética", por exemplo, escrito em 1922 e publicado no livro $O$ Espírito na Arte e na Ciência" ${ }^{138}$, apresenta o que se poderia chamar de "teoria estética junguiana", segundo a qual ele distingue dois processos distintos de criação artística, oriundos de intenção psíquica consciente ou inconsciente. No ensaio, Jung defende a ideia de que existem obras que nascem totalmente da intenção e determinação de seu autor, visando a resultados específicos. Nesse caso, o material é subordinado a um propósito, e o artista está completamente integrado e identificado com ele. E existem também aquelas obras que são originárias do inconsciente, de modo que se impõem trazendo em si sua própria forma:

[...] sua mão de certo modo é assumida, sua pena escreve coisas que sua mente vê com espanto. [...] Enquanto seu consciente está perplexo e vazio diante do fenômeno, ele é inundado por uma torrente de pensamentos e imagens que jamais pensou em criar e que sua própria vontade jamais quis trazer à tona. [...] Ele tem consciência de estar submetido à sua obra ou, pelo menos, ao lado, como uma segunda pessoa que estivesse entrando na esfera de um querer estranho ${ }^{139}$.

\footnotetext{
${ }^{136}$ PAREYSON, Luigi. Estética - teoria da formatividade. Petrópolis: Vozes, 3a edição, 1993. (pp 59-60)

${ }^{137}$ JUNG, op. cit. Sonu Shamdasani in Introdução (2017, p 56)

138 JUNG, C. G. O espírito na arte e na ciência. Petrópolis: Vozes, 2013(b).

${ }^{139}$ Idem. (p 74)
} 
Jean Dubuffet ${ }^{140}$ também divisou duas ordens na arte: a arte estabelecida, polida, acadêmica, bem-acabada, e a arte bruta. O termo idealizado inicialmente por ele - Art Brut - remete à preciosidade de uma arte bruta, que mesmo sem a lapidação convencional não perde sua originalidade e valor; ou, ainda, a pureza e autenticidade de um tecido cru, não tingido, eis seus argumentos:

Assistimos aqui à operação artística completamente pura, bruta, reinventada por inteiro em todas as suas fases por seu autor, partindo apenas de seus próprios impulsos ${ }^{141}$.

[...] trabalhos executados por pessoas desprovidas de cultura artística, para quem a mimese, ao contrário do que ocorre com os intelectuais, desempenha função muito pequena ou nenhuma, de modo que seus criadores retiram tudo (temas, escolha de materiais, meios de transposição, ritmos, modos de escrita etc.) de suas próprias profundezas e não dos estereótipos da arte clássica ou da arte do momento ${ }^{142}$.

Em linhas gerais, essa arte parte do pressuposto da existência do artista autodidata que desenvolve o seu trabalho criativo em resposta a uma forte motivação intrínseca que independe do reconhecimento externo; utiliza frequentemente técnicas e materiais inéditos e improváveis, sem influência direta da arte erudita ou mesmo da arte popular tradicional, não importando por quais motivos. A primazia nessa arte é emergência da arte através do sujeito, e a necessidade de pôr em forma alguma coisa para si e por si mesmo, a partir de um impulso criador que se realiza no próprio ato.

Em sua maioria, essas obras não foram criadas com pretensões artísticas, assim como também não o foram as esculturas do Antigo Egito ou as máscaras africanas que encantaram Picasso; como citou Malraux no Museu Imaginário, a Palas Ateneia só ganhou a condição de "estátua" ao ingressar no museu [...]. Não existem respostas fáceis para essas questões. Mas não podemos deixar de observar como essas obras se impuseram pela força,

${ }_{140}$ Jean Philippe Arthur Dubuffet, pintor, escultor, artista plástico e escritor francês. Foi o primeiro teórico e colecionador da Arte Bruta. Autor do ensaio "Asphyxiante culture", com fortes críticas à cultura dominante, foi o fundador da Compagnie de l'Art Brut. O Museu de Arte Bruta de Lausanne constituiu-se a partir do acervo oriundo da doação de Dubuffet, em 1971, de 5.000 obras.

\footnotetext{
${ }^{141}$ CRUZ JUNIOR, Eurípedes Gomes. In "Do asilo ao museu - ciência e arte nas coleções da loucura". Tese de Doutorado apresentada à Coordenação do Programa de Pós-Graduação em Museologia e Patrimônio - PPGPMUS, UNIRIO/MAST, linha de pesquisa 2: Museologia, patrimônio integral e desenvolvimento. Rio de Janeiro, 2015. (Debuffet apud Cruz Junior, p. 115)

142 “Catálogo da XVI Bienal de São Paulo - Arte Incomum”. (OSÓRIO apud DEBUFFET, pp 11-12, 1981)
} 
estranheza, integridade, gerando processos diferentes de assimilação pela sociedade ${ }^{143}$.

Consoante com a fala do próprio Jung e com tal teoria, o LV, portanto, seria obra emergente dessa arte que se poderia chamar arquetípica, pois impõe sua forma confrontando o sujeito por meio das forças criativas do inconsciente. $\mathrm{O}$ momento histórico também é convergente a tal percepção, pois a perspectiva de uma arte oriunda de forças criativas inconscientes inspirou algumas das vanguardas do século XX. Os olhos dos artistas voltaram-se rumo ao Oriente Interior, em busca do elo perdido com a autenticidade, expressão genuína, valores ancestrais e irracionais que a arte tradicional não proporcionava. Dentre os principais movimentos artísticos que se colocam como oriundos do âmbito do inconsciente destacam-se o surrealismo e a arte visionária.

O surrealismo foi um movimento artístico e literário nascido em Paris na década de 1920, fortemente influenciado pelas teorias psicanalíticas enfatizando o papel do inconsciente na atividade criativa. Seu propósito era produzir uma arte que, segundo o movimento, estava sendo destruída pelo racionalismo. A palavra surrealismo supoõe-se ter sido criada em 1917 pelo poeta Guillaume Apollinaire. André Breton, escritor e poeta francês, escreveu em 1924 o Manifesto Surrealisata, por meio do qual ofereceu ao mundo uma nova perspectiva da arte.

A arte visionária pode ser entendida como um fazer artístico ou processo criativo, onde a produção está condicionada às experiências advindas de estados não ordinários de consciência - ENOC. Seu propósito é transcender o mundo físico, retratar visões que muitas vezes incluem temas espirituais e místicos ou, pelo menos, alicerçados em tais experiências. Essa estética não é um fenômeno novo, diversos artistas ao longo da história ofereceram tais perspectivas. Segundo Caruana, escritor do Primeiro Manifesto da Arte Visionária:

Onde os Surrealistas tentaram, através do estado onírico, elevarse às mais altas realidades (e contra o uso de narcóticos), os artistas visionários usam tudo a sua disposição - mesmo com grande risco pessoal - [para] acessar diferentes estados de consciência e expor as visões resultantes. Os artistas visionários buscam mostrar o que repousa além das fronteiras de nossa percepção. Através dos sonhos, transes ou outros estados alternativos, o artista busca ver o invisível (ou o mundo dos

${ }^{143}$ Cruz Junior, op.cit. (2015, p 115) 
espíritos) - atingindo um estado visionário que transcende nosso modo ordinário de percepção. A tarefa que o espera, consequentemente, é comunicar suas visões de forma reconhecível como na visão do dia a dia ${ }^{144}$.

Muitos artistas contemporâneos a Jung estavam também engajados em intersecções entre experimentações artísticas e psicológicas, de modo que o processo vivenciado por Jung não chegava a ser uma idiossincrasia ${ }^{145}$. Se tivesse conscientemente a intenção e determinação de fazer arte, com suas conexões pessoais, poderia facilmente ter exposto seu trabalho, ou seja, sua recusa em considerar arte o que fazia ocorre em um contexto de possibilidades reais para seguir esse caminho, se assim o desejasse ${ }^{146}$. Não obstante suas resistências, Jung é confrontado pela emergência da arte, não do sujeito, mas através do sujeito, e seguira, sem se dar conta, o caminho do artista, aquele que confrontado pelas forças criativas, descobre o modo de fazer fazendo e realiza-as na vida.

No decurso do processo, em 1915, espontaneamente começou a desenhar mandalas ${ }^{147}$ e, subsequentemente, a estudá-las. Pouco a pouco compreendeu-as como uma espécie de criptograma que expressavam seu estado de ser, pois para Jung, o mandala expressa formação, transformação, eterna recriação da Eterna Mente. Foi por meio dessa forma que compreendeu o propósito da psique, elaborando, por fim, o conceito de self - o ápice e o centro do desenvolvimento da personalidade integral.

As imagens abaixo, publicadas recentemente (2019) no livro A arte de $C$. G. Jung, são alguns dos registros das expressões dos seus estados de ser por meio de mandalas, e, subsequente, as formas que foram adquirindo ao longo do processo. De acordo com Jung, concomitante ao desenvolvimento das figuras, podem-se acompanhar o processo de desenvolvimento da personalidade ou seu

\footnotetext{
${ }^{144}$ CARUANA, L. O primeiro manifesto da arte visionária. Curitiba: URCI-GLP, 2013 (p 1).

145 JUNG, op. cit. Sonu Shamdasani in Introdução (pp 32-33)

${ }^{146}$ Idem.

${ }^{147}$ O termo mandala vem do sânscrito, por sua vez, a tradição brâmane remonta possivelmente às origens druídicas. Significa círculo, mais precisamente círculo mágico. Suas formas representam a harmonia do cosmos e a energia divina presente em toda a natureza. A forma correta de referir-se ao mandala, é "o" mandala. In Mandalas de Rüdiger Dahlke. São Paulo: Pensamento, 1985.
} 
estado de ser. É o que se nota na evolução do processo criativo de Jung com seus mandalas, concomitante a elaboração do conceito de "processo de individuação".
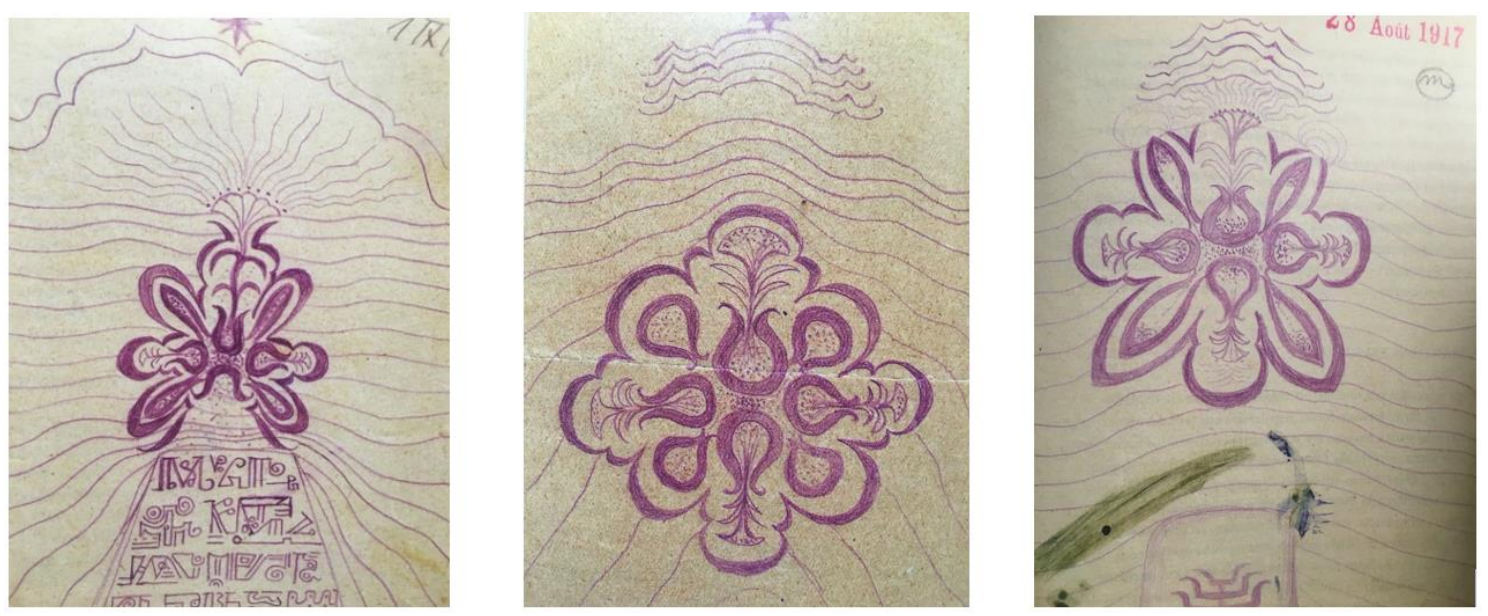

Figura 3: Esboços de mandalas
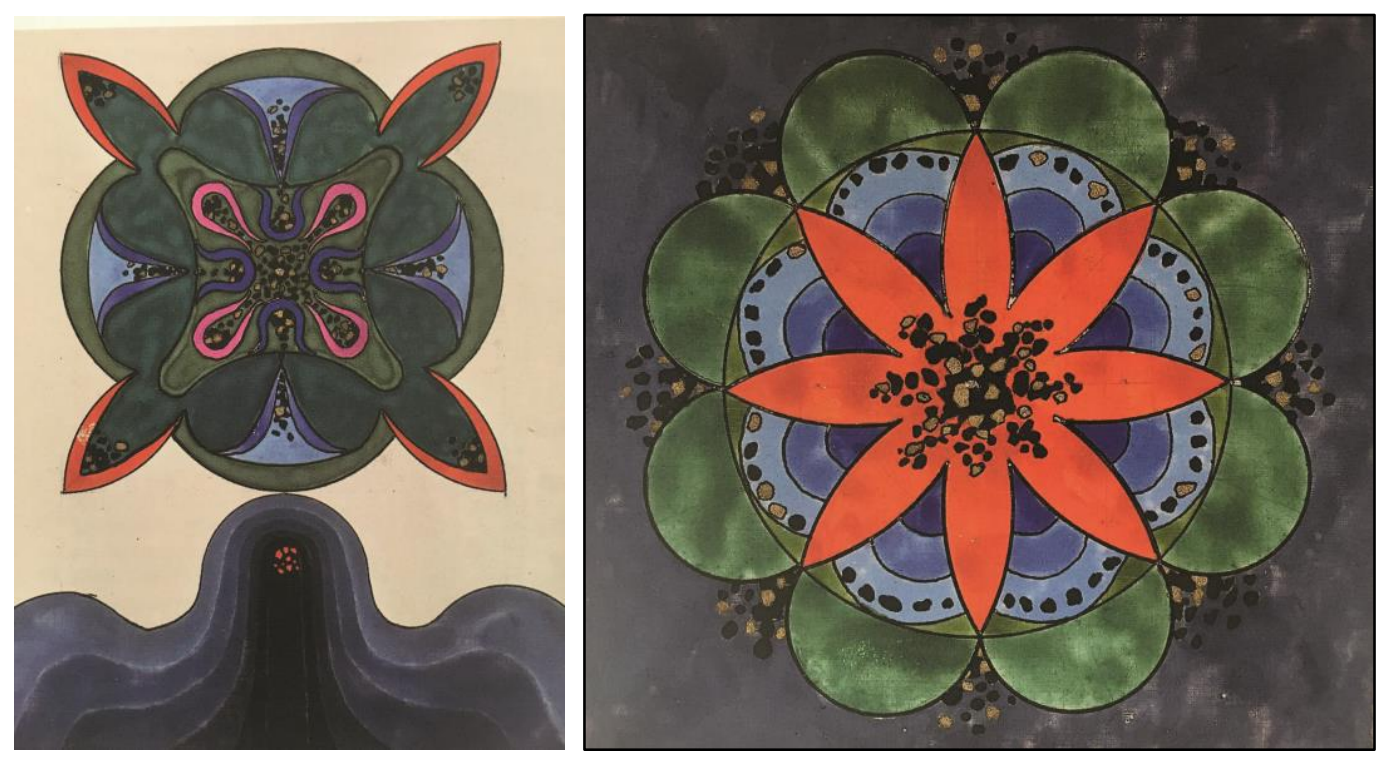

Figura 4: Mandala (p 83/LV)

Figura 5: Mandala (p 82/LV) 


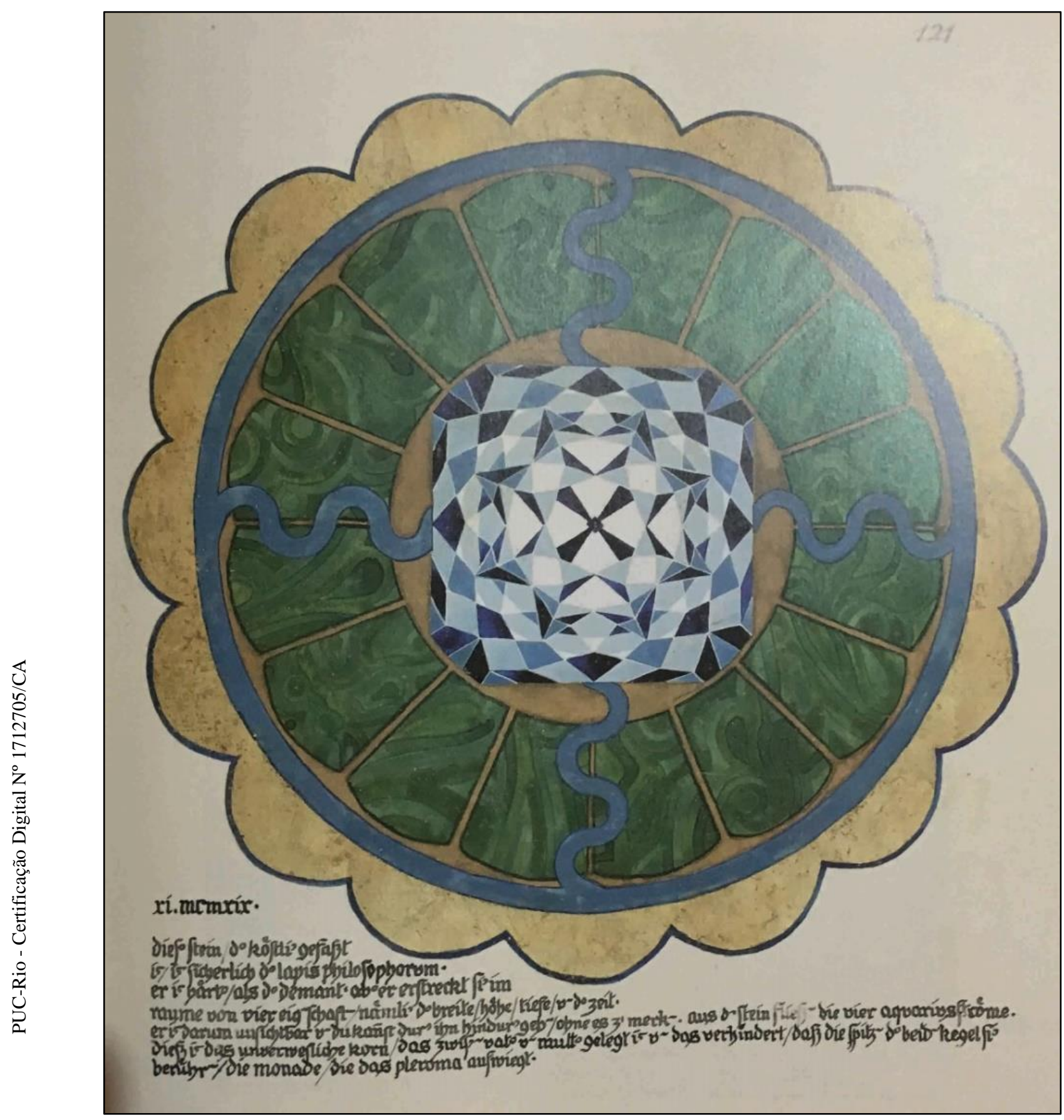

Figura 6: Mandala (p 121 /LV) 
$159^{\circ}$

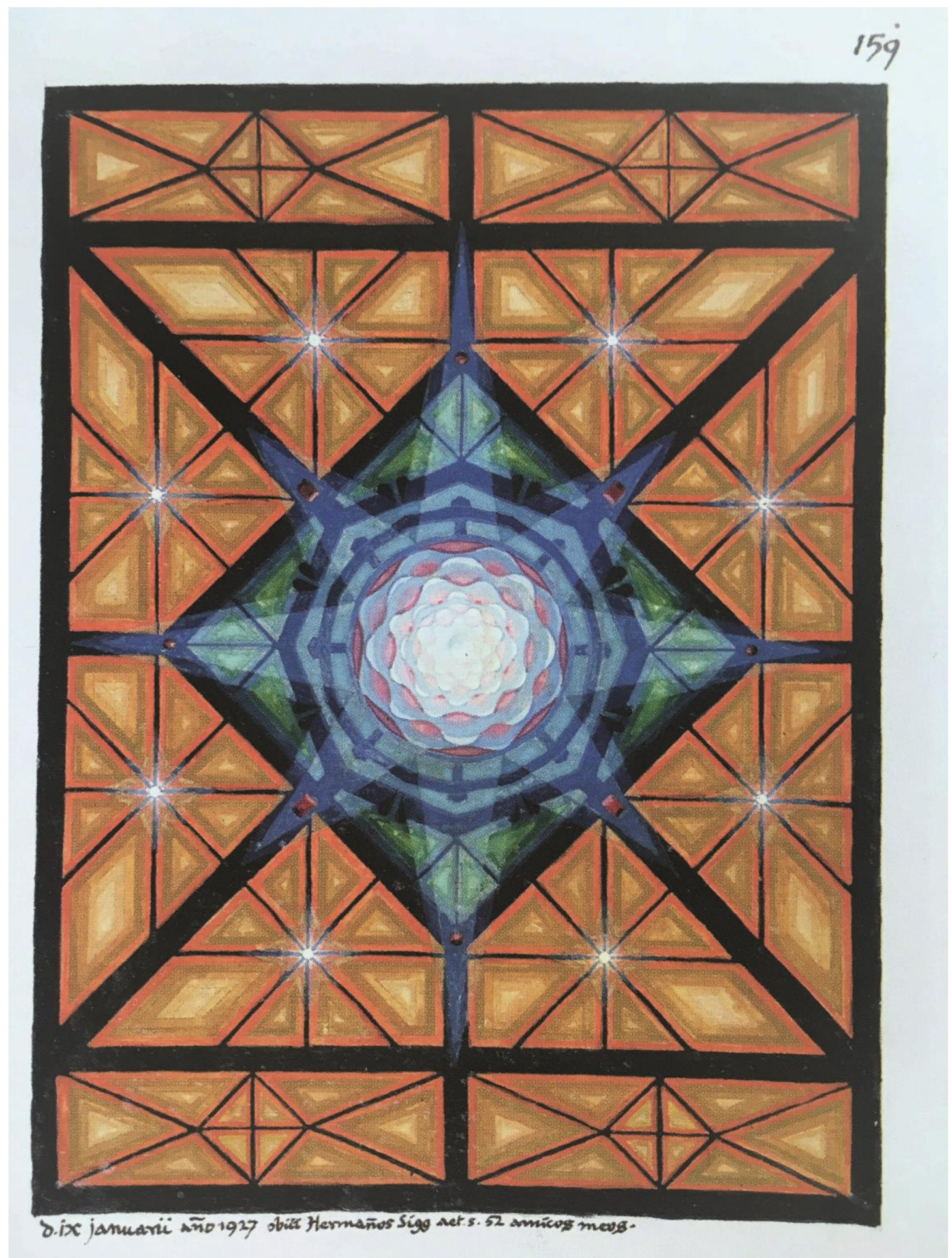

Figura 7: Mandala "Uma flor luminosa no centro com estrelas girando ao seu redor" (p 159/LV) 


\begin{abstract}
"Obrigado a viver, eu mesmo, o processo do inconsciente, tivera que me abandonar inicialmente a esse fluxo, sem saber por onde seria levado. Só quando comecei a pintar os mandalas vi que o caminho que seria necessário percorrer e cada passo que devia dar, tudo convergia para um dado ponto, o do centro. Compreendi sempre mais claramente que o mandala exprime o centro e que é a expressão de todos os caminhos: é o caminho que conduz ao centro, à individuação. [...] tornou-se claro para mim que a meta do desenvolvimento psíquico é o Si-mesmo. A aproximação em relação a esse último não é linear, mas circular, isto é, "circum-ambulatória". [...] Compreender isso deu-me firmeza e, progressivamente, restabeleceu-se a paz interior. Atingira com o mandala - expressão do "si-mesmo" a descoberta última a que poderia chegar. Alguém poderia ir além. Eu não" ${ }^{148}$.
\end{abstract}

Concomitante ao processo criativo de elaboração de seus conteúdos psíquicos, Jung desenvolve e amplia suas concepções. As questões que foram se colocando advindas de suas reflexões sobre o fenômeno que experimentava foram sendo formuladas e publicadas, como por exemplo, a Dialética do eu e do inconsciente que nasceu do primeiro problema a que se propôs: "Que fazer com o inconsciente?"149, e assim sucessivamente. Entretanto, a partir da vivência com os mandalas configura-se um novo projeto: a busca e tentativa de fornecer uma explicação do desenvolvimento e ampliação da personalidade - processo de individuação ${ }^{150}$-, esse, o resultado teórico essencial de sua autoexperimentação. O termo pressupõe, em sua teoria, uma diferenciação anterior das diversas estruturas psíquicas, para em continuum integrá-las em uma totalidade que anuncia mais o sentido de plenitude.

Uso a palavra individuação para designar um processo através do qual um ser torna-se um individuum psicológico, isto é, uma unidade autônoma e indivisível, uma totalidade ${ }^{151}$.

Em primeiro lugar, há uma ampliação da consciência, pois inúmeros conteúdos inconscientes são trazidos à consciência. Em segundo lugar, há uma diminuição gradual da influência

\footnotetext{
${ }^{148}$ Ibid. (p 201)

149 JUNG, op. cit. (2016, p 210)

150 JUNG, op. cit. Sonu Shamdasani in Introdução. (2017 p 56)

${ }^{151}$ DAMIÃO, op. cit. (1997, p 86)
} 
dominante do inconsciente, em terceiro lugar, verifica-se uma transformação da personalidade ${ }^{152}$.

Em 1929, com o livro publicado em colaboração com Richard Wilhelm, oriundo de um tratado alquímico chinês - O segredo da flor de ouro ${ }^{153}$ - suas reflexões e pesquisas atingiram o ponto central da sua psicologia com o conceito de self, quando ele diz ter encontrado o caminho de volta ao mundo ${ }^{154}$. Posteriormente, no prefácio de Estudos Alquímicos ${ }^{155}$, Jung esclarece o que acontecera. Ele diz ter recebido o texto em um momento problemático do seu trabalho: era, então, o ano de 1928, e desde 1913 ele vinha ocupando-se com os problemas do inconsciente coletivo, (isto é, com o autoexperimento configurado como "confronto com o inconsciente") e chegara a resultados que the pareciam questionáveis sob vários aspectos ${ }^{156}$. "Tratava-se de uma vasta fenomenologia, à qual não se podia aplicar as categorias e métodos até então conhecidos ${ }^{157}$,, e seu principal problema consistia justamente em não ter encontrado até então, em nenhum campo da experiência humana, algum apoio, referência ou fundamentação aos resultados obtidos. "Os resultados a que chegara, baseados em quinze anos de esforços, pareciam flutuar, sem qualquer possibilidade de confronto $^{158}$ ". O texto em questão, embora originário de um ramo antiquíssimo da cultura oriental muito diverso e até mesmo de difícil compreensão e assimilação

\footnotetext{
152 JUNG, op. cit. (2017 p 74)

153 O livro revelado ao ocidente em 1929 provém de um círculo esotérico da China. Foi transmitido oralmente durante muito tempo, e depois através de manuscritos. A primeira impressão foi editada por Liu Hua Yang em 1794. Posteriormente, em 1921, alguém sob o pseudônimo de Hui Dschen Dsï (aquele que se tornou consciente da verdade) imprimiu uma tiragem de mil exemplares que foi distribuída a um pequeno círculo de pessoas que, segundo o editor, eram capazes de compreender as questões expostas no livro. A tradução de Richard Wilhelm e Jung provém dessa edição.

154 JUNG, op. cit. (2016, p 211)

155 JUNG. C. G. Estudos Alquímicos. In “Prefácio”. Petrópolis: Vozes, 2003.

${ }^{156}$ Idem. Claramente ele se reporta ao seu confronto com o inconsciente e elaboração estética do $L V$.

${ }^{157}$ Idem.

${ }^{158}$ Idem.
} 
pela cultura ocidental ${ }^{159}$, continha - em termos conexos - justamente o fundamento que tanto buscara ${ }^{160}$.

A obra reúne instruções budistas e taoístas de meditação. A concepção fundamental consiste no pressuposto de que, pelo nascimento, as duas esferas anímicas do consciente e do inconsciente são separadas uma da outra. $\mathrm{O}$ consciente é o elemento da diferenciação individual e o inconsciente, o elemento da união cósmica. O princípio da obra baseia-se na integração de ambos os elementos pelo caminho da meditação. O inconsciente deve ser como que fecundado pela submersão do consciente, deve ser trazido à consciência; juntamente com o consciente assim ampliado, acede então a um plano de consciência suprapessoal, na forma de um renascimento espiritual. Tal renascimento determina primeiro uma contínua diferenciação interior do estado de consciência, a modo de formas de pensamento que se tornam independentes. No entanto, o desfecho da meditação leva necessariamente à dissolução de todas as diferenças numa unidade última e vital, sem dualidade ${ }^{161}$.

Jung comenta que o contato com tal texto abriu um acesso novo e inesperado à sabedoria oriental, e dá-se conta de como ele ia seguindo inconscientemente esse caminho ${ }^{162}$. De acordo com ele, o conteúdo representava um paralelo vivo com o que ocorria no processo de desenvolvimento psíquico que observava. Tal analogia pode ser entendida na premissa de que "as diversas linhas de desenvolvimento anímico partem de uma base comum, cujas raízes mergulham no passado mais distante ${ }^{163}$ ". O caminho experimentado e formulado por Jung com propósito de integração do consciente e inconsciente - processo de individuação - é facilitado por meio da imaginação ativa, que se poderia chamar também de meditação ativa ${ }^{164}$.

[...] consiste primeiramente nos exercícios sistemáticos de eliminação da atenção crítica, criando, assim, um vazio na consciência, que favorece o surgimento de fantasias que estavam latentes ${ }^{165}$. O objetivo consiste em permitir à fantasia

\footnotetext{
159 JUNG, WILHELM, C. G., R. O segredo da flor de ouro. Petrópolis: Vozes, 2013a. (p 23-24)

160 JUNG, op. cit. (2003) Isso representou para ele, conforme ele, diz o caminho de volta ao mundo.

${ }^{161}$ JUNG, op. cit. (2013a, p 85)

162 JUNG, op. cit. Sonu Shamdasani in Introdução. (2017 p 27)

163 Ibid. (p 28)

164 Dentre as inúmeras técnicas de meditação, diferencia-se na prática entre o caráter ativo ou passivo, todavia, o resultado almejado em última instância é o mesmo.

165 JUNG, op. cit. (2013b, p 24)
} 
agir livremente, sem afastar-se do afeto inicial, num livre processo associativo. Isto levava a uma expressão concreta ou simbólica do estado de espírito, o que tinha como consequência trazer o afeto para mais perto da consciência, tornando-o assim, mais compreensível ${ }^{166}$.

A expressão de tal estado de ânimo anteriormente subjetivo e não relacionado converte-se, assim, em uma ideia mais ou menos objetiva ${ }^{167}$. Pode-se expressá-lo então por meio de imagens conferindo-lhe uma forma visível, através do desenho, pintura, escultura, escrita automática etc., dependendo da facilidade ou aptidão do indivíduo ${ }^{168}$, pois é necessário que, frente a tais fantasias, o sujeito interaja ativamente com elas - imagem $e$ ação ${ }^{169}$-, e não passivamente, como se fora um devaneio. No momento em que a consciência é confrontada objetivamente com tais conteúdos é quando ocorre uma reação, dantes imprevista,

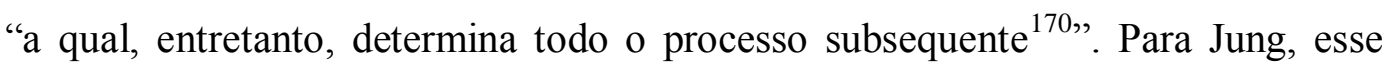
momento aponta para duas tendências: a formulação criativa e a compreensão.

Onde predomina o princípio da formulação criativa, os materiais obtidos aumentam e variam, resultando em uma espécie de condensação dos motivos em símbolos estereotipados, onde predominam os motivos estéticos. Essa tendência leva ao problema estético da formulação artística; onde, ao contrário, predomina o princípio da compreensão, o aspecto estético interessa muito pouco e ocasionalmente pode ser sentido como um obstáculo. Em vez disso, há uma luta imensa para compreender o sentido do produto inconsciente ${ }^{171}$.

Tais tendências correspondem à índole pessoal do indivíduo ${ }^{172}$, entretanto, em última instância, "a formulação estética precisa da compreensão do significado do material, e a compreensão, por sua vez, precisa da formulação estética ${ }^{173,}$, pois

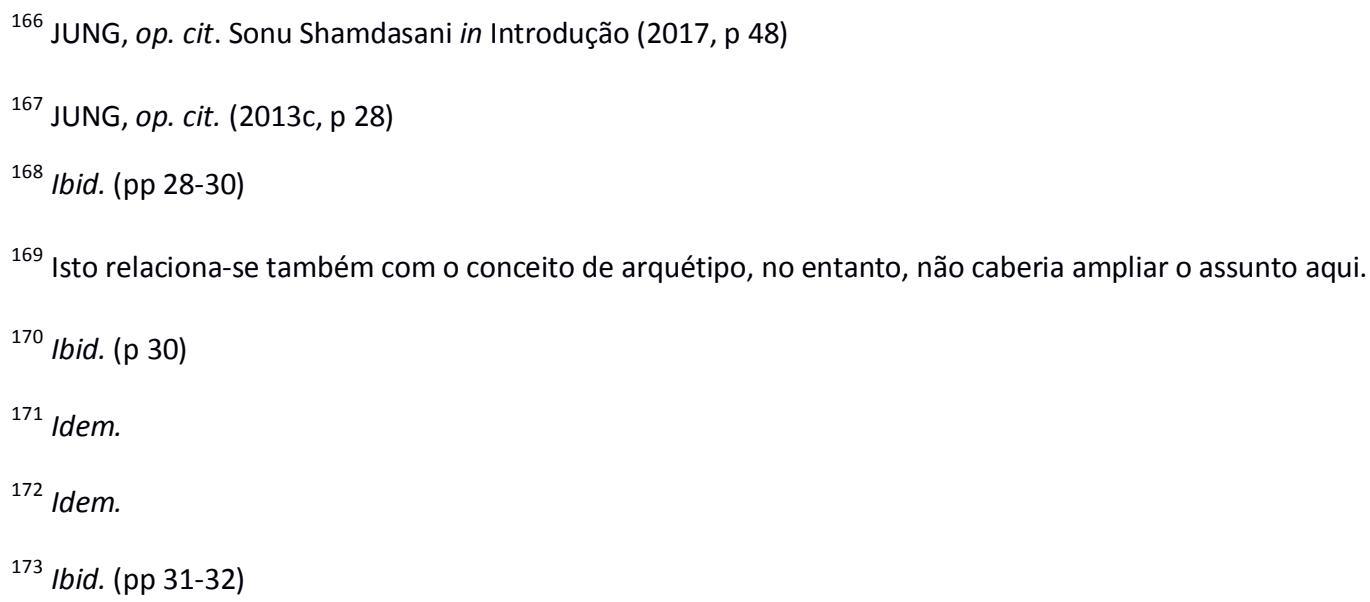


somente a sua união promove o fenômeno psíquico chamado por Jung de "função transcendente ${ }^{174,}$, que consiste justamente na união dos conteúdos conscientes e inconscientes, por meio do qual se alcança a individuação ou, em linguagem mais acessível, a ampliação da personalidade através da sua integração. O grande desafio para ocorrer a união desse par de opostos em uma unidade indivisível consiste justamente no confronto, diálogo e aceitação da parte oposta e complementar.

Retomando o questionamento de Jung quanto à natureza artística ou científica da obra, parece-nos que de sua formulação criativa resultou seu $O$ Livro Vermelho, e de sua busca por compreensão resultou um modelo psicoterapêutico construtivo. Raro em sua experimentação foi sua visada sobre a psique a partir de dentro, e a forma como se relacionou com essa imaginação, essencialmente criadora.

Foi naturalmente uma ironia do destino o fato de eu ter encontrado, como psiquiatra, passo a passo, no curso de minha existência, esse material psíquico que fornece as pedras com que se constrói uma psicose e que consequentemente se encontra nos manicômios. Refiro-me ao mundo das imagens inconscientes que mergulham o doente mental em uma confusão funesta, mas que também é a matriz da imaginação criadora ${ }^{175}$.

Ao encontrar fundamentos convergentes aos seus pressupostos, ele pode publicar alguns dos resultados essenciais de sua pesquisa. Ademais, o contato com esse antiquíssimo tratado alquímico chinês levou-o ao encontro da alquimia, por meio da qual, após um estudo aprofundado, conseguiu encontrar a via correta que estabelecia a ponte histórica entre a gnose e os processos do inconsciente coletivo que podiam ser observados no homem contemporâneo ${ }^{176}$. Desde então, a elaboração científica do processo de individuação e sua comparação histórica e intercultural viriam a ocupá-lo pelo resto da vida ${ }^{177}$.

\footnotetext{
${ }^{174}$ Ibid. (p 13)

175 JUNG, op. cit. (2016, pp 194)

176 Ibid. (p 8)

177 JUNG, op. cit. Sonu Shamdasani in Introdução. (2017 p 45)
} 
Depois de anos, no outono de 1953, ele volta ao livro para concluir uma imagem que ficara inacabada, porém não o conseguiu. Em seu lugar compôs um novo e longo diálogo, imaginário, ligado aos primeiros compostos no livro, e com os mesmos personagens. Ainda dessa vez escreveu cuidadosamente com tinta nanquim da China e caracteres góticos ${ }^{178}$. O livro seria concluído com um apêndice, escrito em 1959, única página do livro com sua letra original; no entanto, ficou inacabado; o texto interrompe-se no meio de uma frase. Eis o que dizia: ${ }^{179}$

"Trabalhei neste livro durante 16 anos. Em 1930, meu contato com a alquimia afastou-me dele. Em 1928, situa-se o começo do fim, quando Wilhelm pôs ao meu alcance o texto do tratado alquimista $O$ segredo da flor de ouro. O conteúdo do livro encontrou, então, o caminho da realidade e não pude mais trabalhar nele. Sempre soube que as experiências continham coisas preciosas e foi por isso que nada de melhor soube fazer que as traduzir num livro 'precioso', isto é, de grande valor, e representar em pinturas tão fiéis quanto possível as imagens que reapareciam enquanto eu as descrevia. (...) a despeito de ser um enorme trabalho e de alguns desvios, permaneci fiel a ele; mesmo se qualquer outra possibilidade nunca...."180.

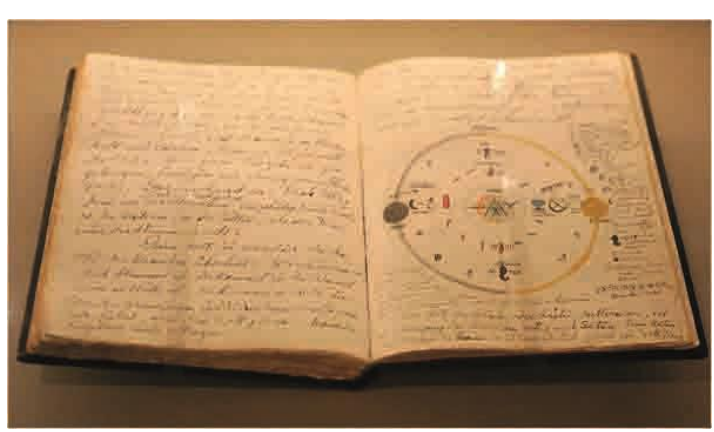

Figura 8: Registros no Livro Negro

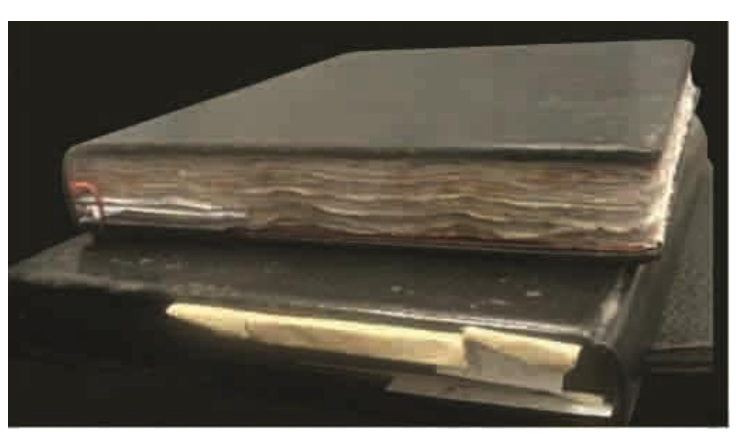

Figura 9: Livros Negros

\footnotetext{
${ }^{178}$ Idem.

${ }^{179}$ Idem.

${ }^{180}$ Idem.
} 


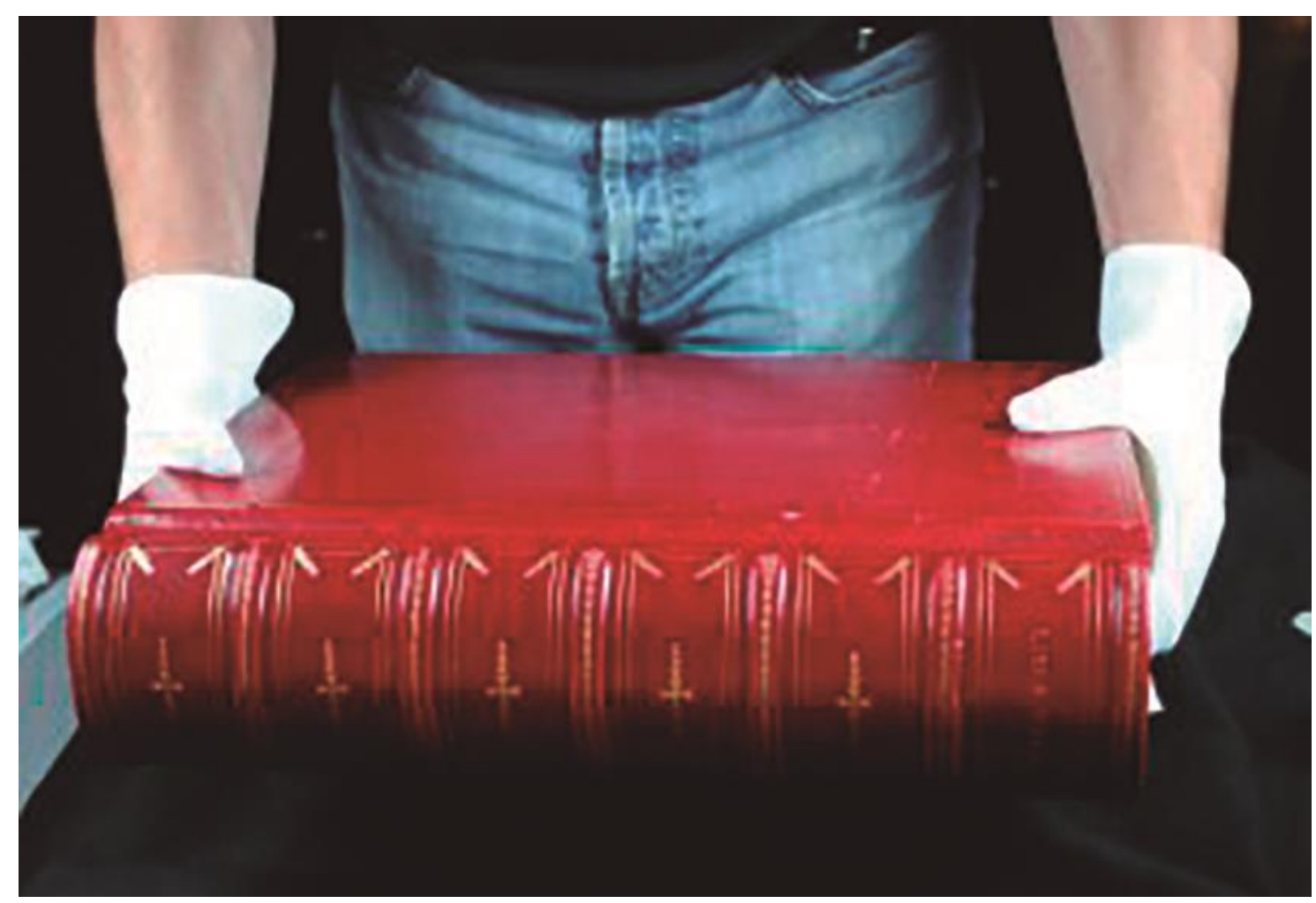

ป

Figura 10: O Livro Vermelho Original 


\subsection{A poética d'O Livro Vermelho}

"Eu fiz como minha alma sugeriu, e moldei na matéria os pensamentos que ela me deu. Ela me falou muitas vezes e demoradamente da sabedoria que está por trás de nós ${ }^{181 \%}$.

O Livro Vermelho, afinal, é um corpus manuscrito inacabado ${ }^{182}$. Inserido em um in-fólio feito de pergaminho e encadernado em couro vermelho $^{183}$, está organizado como uma iluminura medieval ${ }^{184}$, caligrafada e encabeçada por uma tábua de abreviações ${ }^{185}$. Inclui narrativas, diálogos, orações, sermões de cunho metafórico ou mitológico, encantações, além das pinturas - iluminuras, iniciais historiadas, decoradas ou iluminadas, e os mandalas - pintadas com guache, aquarela e têmpera ${ }^{186}$, formando um conjunto de elementos linguísticos e visuais ${ }^{187}$, no qual cada um pode ser visto também de forma independente.

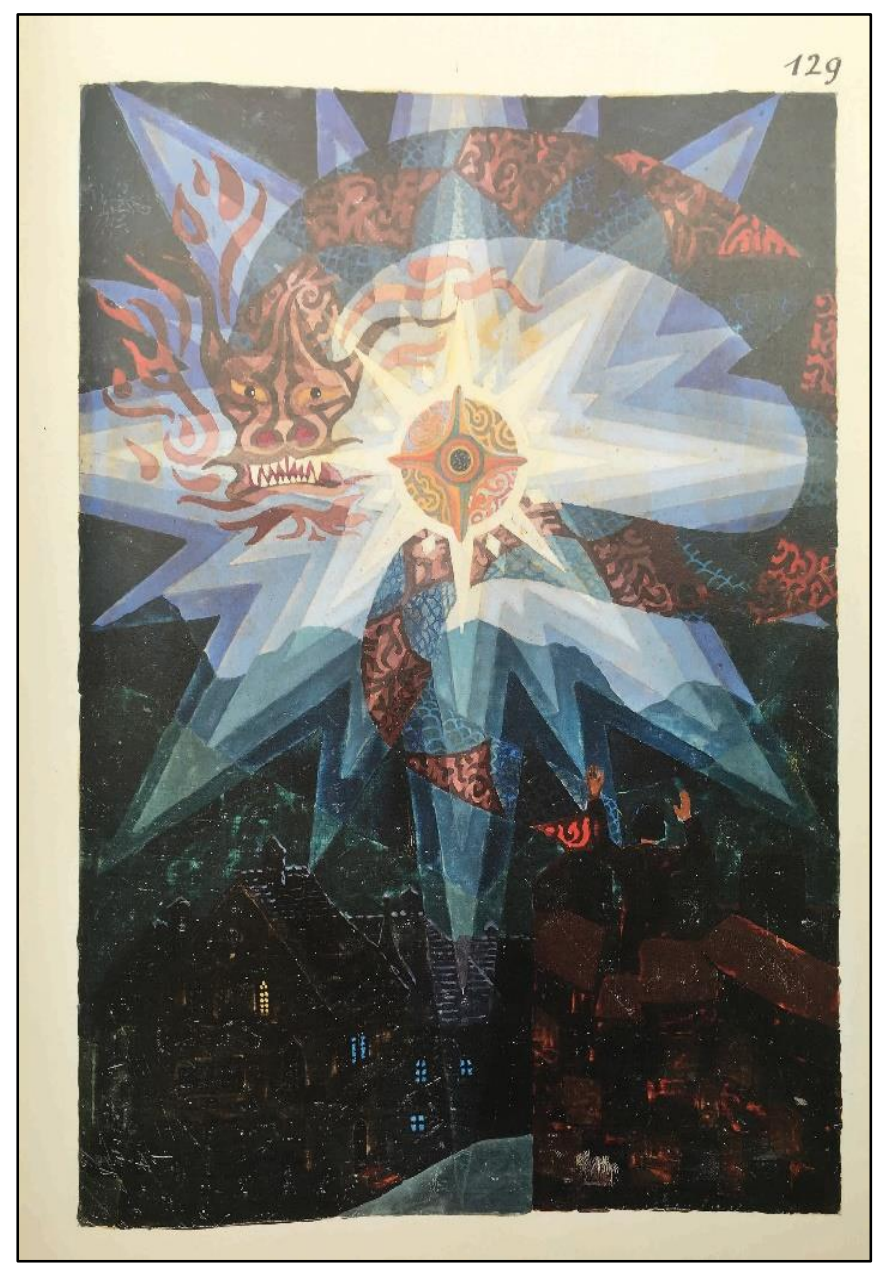

Figura 11: Ilustração sem título da série "Encantações" (p $129 /$ LV)

\footnotetext{
181 JUNG, op. cit. (2017, p 345)

182 JUNG, op. cit. In “Nota Editorial” (2017, p 95)

${ }^{183}$ Ibid. (2017, p 29)

${ }^{184}$ O capítulo três desta dissertação apresenta detalhadamente os manuscritos medievais e suas iluminuras.

${ }^{185}$ Idem.

${ }^{186}$ Idem.

${ }^{187}$ HOERNI, FISCHER E KAUFMANN, Ulrich, Thomas e Bettina. A arte de C. J. Jung. Petrópolis: Vozes, 2017. In "Uma seleção de iniciais iluminadas de O Livro Vermelho" por Ulrich Hoerni. (p247)
} 


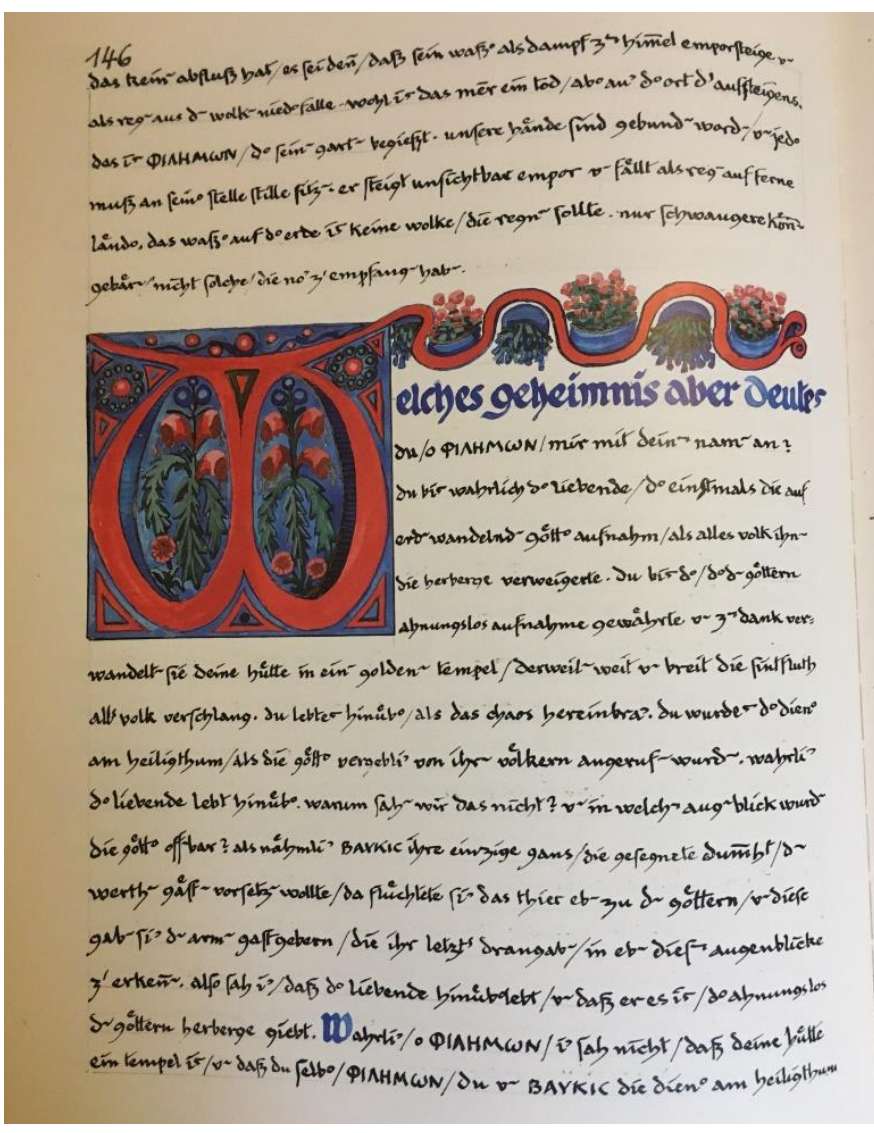

Figura 12: Iluminura manuscrita com caligrafia gótica

$$
\text { (p } 146 \text { / LV) }
$$

Por que Jung teria decidido fazer seu livro precioso com aparência de manuscrito medieval iluminado? Evidentemente, só podemos tecer conjunturas e seguir pistas deixadas na bibliografia consultada, pois além de descrever que um livro precioso para ele seria um livro de grande valor, não há referências quanto à escolha desse modelo. Sabemos que Jung era homem culto, amante e colecionador de arte $\mathrm{e}$ grande leitor, portanto, não

lhe faltavam referências. William Blake, "com cuja obra Jung tinha certa familiaridade", é uma delas. A poética alcançada por Jung lembra muito a composição de texto e imagem das iluminuras de Blake; seus livros, inclusive, são considerados como caso singular na história do livro ${ }^{188}$. Um fator não menos relevante fundamenta-se no contexto histórico de sua época, apontando para o movimento engendrado pelas chamadas gráficas particulares - private press ${ }^{189}$ que em oposição às gráficas comerciais, reagiram com vigor contra a uniformização massificada do livro ${ }^{190}$. William Morris, admirador da caligrafia gótica, fundou uma das mais expressivas dentre essas gráficas, a Kelmscott Press, que, com o

${ }^{188}$ ARAÚJO, op. cit. (2008)

189 A expressão vem do inglês e designa uma gráfica particular cujo interesse não seja estritamente comercial. Tal modelo de negócio já existia em meados do século XV, e subsistiu ao longo da evolução do livro impresso, revigorando-se no final no século XIX frente à massificação do livro. $O$ assunto será aprofundado no capítulo quatro desta dissertação.

190 ARAÚJO, op. cit. (2008, p 462) 
propósito de resgatar a beleza das publicações dos incunábulos ${ }^{191}$ do século XV, reabilitou o livro como produto de um processo artesanal fomentando um novo mercado de livro de arte. Cabe sublinhar que essas casas editoriais que buscavam resgatar o livro feito com arte, inspiradas pelo valor e preciosidade dos manuscritos iluminados e dos primeiros incunábulos, produziram os primeiros livres d'art, livres de peintre e os livres d'artiste, fomentando diretamente o advento do campo do livro de artista, ou seja, assim como $O$ Livro Vermelho não é de fato um manuscrito medieval e nem um livro de artista, os livros produzidos pelas private press também estão neste lugar - por um lado precursores dos livros de artista, por outro, resgatando a arte e a aparência destes nossos primeiros livros. Outro fator que consideramos preponderante e que se relaciona com a estética do manuscrito medieval iluminado é o tema central do livro: o encontro de Jung com sua alma e a criação de uma cosmologia individual por meio da qual se busca o renascimento de Deus $^{192}$, remetendo-nos ao valor cultural e simbólico do livro enquanto fundamento religioso e eixo central do cristianismo. Acontece que todo o desenvolvimento da arte de iluminar os primeiros códices medievais originou-se com o propósito de embelezar o livro sagrado para os olhos de Deus, tornando-o assim um objeto precioso e de grande valor. Justamente por isso, o trabalho dos monges na feitura desses livros tinha um caráter meditativo e sagrado, de forma que o monge que iluminasse esses textos realizava uma tarefa que ia muito além do âmbito artístico: "seria como dar à luz um conteúdo sagrado, para além das palavras"193. Certamente tais especificidades vão ao encontro das questões relacionadas ao processo de criação do Liber Novus. Referente a Jung, entretanto, há um aspecto particular que nos chama a atenção: sua atração pela história e cultura da Idade Média, que o levou, inclusive, a estudar e mergulhar intensamente na teologia medieval ${ }^{194}$. Acreditava que a humanidade precisava resgatar algo que ficara mal resolvido com o medievo, e, principalmente, sentia que ele próprio tinha algo a encontrar ali - "Eu

\footnotetext{
191 Primeiros livros impressos que, todavia, mantinham a estética dos manuscritos medievais.

192 JUNG, op. cit. Sonu Shamdasani in Introdução. (2017 p 28)

${ }^{193}$ FAILLACE, Vera Lúcia Miranda. Catálogo dos Livros de Horas da Biblioteca Nacional. Rio de Janeiro: FBN (Fundação Biblioteca Nacional), 2016. (p 21)

${ }^{194}$ Ibid. (p 404)
} 
tenho de recuperar um pedaço da Idade Média em mim"195 -, conforme escreve na última página do Liber Secundus ${ }^{196}$. Considerando que no fim do processo de criação do livro (isto é, passados cerca de 16 anos dedicados à sua elaboração), seu encontro com a alquimia - e o fundamento que ela oferece como ponte histórica que liga a gnose do medievo às questões propostas por meio do conceito de inconsciente coletivo para o homem contemporâneo - fecha o ciclo do processo de criação do livro e o leva, conforme ele mesmo relata, de volta ao mundo. Pode-se dizer que, de fato, Jung recuperou um pedaço da Idade Média. Assim, nada mais apropriado (embora seja evidente que ele mesmo desconhecia tal ligação), que seu livro precioso trouxesse tal estética para o contemporâneo.

Quanto às cores escolhidas para os Livros Negros e para O Livro Vermelho, pensamos que os primeiros fazem alusão ao negro devido ao caráter oculto e desconhecido do inconsciente, e também devido ao fato de seu propósito ser o de salvaguardar secretamente o registro de uma opus pessoal. Já o vermelho que caracteriza o Liber Novus, justamente o "livro novo" que surge como projeto de um livro precioso para acolchoar a experiência dantes registradas, provavelmente tem relação com os sentidos de realeza, valor e sofisticação atribuídos culturalmente à cor. Todavia, em nota escrita em carta endereçada a Jung, mas não enviada, Cary Baynes, colaboradora na transcrição do Liber Novus, escreve que Jung lhe falara de um certo "Livro Vermelho" mencionado por Meyrink em seu livro Dominicano Branco, como portador de certos mistérios ${ }^{197}$. Nesse livro propriamente dito, o herói do romance, Christopher, é informado de que "quem possuir o livro vermelho de cinábrio, a planta da imortalidade, o despertar do sopro espiritual e o segredo de trazer à vida $[\ldots]^{198}$. Shamdasani comenta que tal "livro vermelho" do mencionado romance "chama-se livro de cinábrio porque, de acordo com uma antiga crença da China, o vermelho é a cor das vestes dos que alcançaram o mais alto estágio da perfeição e haviam permanecido para trás na terra para salvar

\footnotetext{
195 Idem.

${ }^{196}$ Idem.

197 JUNG, op. cit. Sonu Shamdasani in Introdução. (2017 p 58)

198 Idem.
} 
a humanidade" ${ }^{\text {199 }}$. Evidente que, considerando-se o interesse de Jung nos romances de Myrinck, alguma influência há de ter ocorrido. Não se pode, contudo, deixar de mencionar a relação que se coloca, uma vez mais, a posteriori, com as fases alquímicas da opus de seus processos anímicos. Nigredo (escuridão), um estágio subjetivo e inconsciente. Rubedo (vermelhidão), o resultado da jornada que colhe na escuridão a prima materia e a purifica pela luz da Lua e do Sol: quebrar, limpar e juntar novamente, compondo a pedra filosofal. Vermelho é a cor que simboliza o trabalho alquímico bem-sucedido. Há ainda os estágios caracterizados pelo branco e amarelo - Albedo e Citrinitas -, que, no entanto, são fases compreendidas entre o Nigredo e o Rubedo, de modo que os Livros Negros poderiam ser perfeitamente relacionados com o Nigredo, e O Livro Vermelho com o Rubedo.

\subsubsection{O manuscrito caligrafado}

A caligrafia por meio da qual se escreve o texto propriamente dito, é mais um elemento que impacta o conjunto da obra devido à forte pregnância visual. O texto manuscrito traz uma expressão em si: mais do que expressar os signos da linguagem, traz o gesto em sua composição, pois, no ato de escrever, o gesto capturado entra em jogo com a arte ao desdobrar-se em texturas que além da experiência visual sugerem experiências táteis. Em plena era digital na qual a desmaterialização da escrita torna-se regra, o ato de escrever e seu gesto torna-se desenho e composição. Resgatando o sentido que a palavra graphein tinha para os gregos, designa tanto o ato de escrever como o ato de desenhar ${ }^{200}$. Tais especificidades ressignificadas na perspectiva da arte contemporânea, colocam a arte da bela escrita com status de arte em si. Ademais, sugere a aura de presença do autor.

Peso, leveza, força, delicadeza, movimento, pausa, ritmo e expressão são alguns dos atributos que as letras e as palavras ganham com a arte da caligrafia. (...) Desvelam cores, texturas, linhas, curvas e retas. A caligrafia lembra-nos que a escrita é também extensão do corpo. Algumas gerações viveram a

\footnotetext{
199 Idem.

${ }^{200}$ Revista Gráfica \# 75/76. Gabriela Irygoien in “Type Designer/Caligrafia/Calligrafhy: Claudio Gil”, 2011.
} 
emoção de receber cartas escritas à mão. Reconhecer a grafia do amigo distante era como sentir sua presença, ouvir sua $\operatorname{voz}^{201}[\ldots .$.$] . A caligrafia é a presença física das letras/palavras no$ mundo. É a memória do gesto, a marca da passagem do indivíduo. [...]. A valorização da forma visual, das possibilidades e recursos gráficos das palavras que devem ser "vistas" mais do que lidas, dialoga com a poesia concreta. A caligrafia também permite maior ousadia na "ocupação" do papel, do espaço visual. Os manuscritos medievais, em termos de ocupação gráfica do papel e organização visual do pensamento, eram mais ousados e interessantes que as colunas impressas de texto $[\ldots]^{202}$.

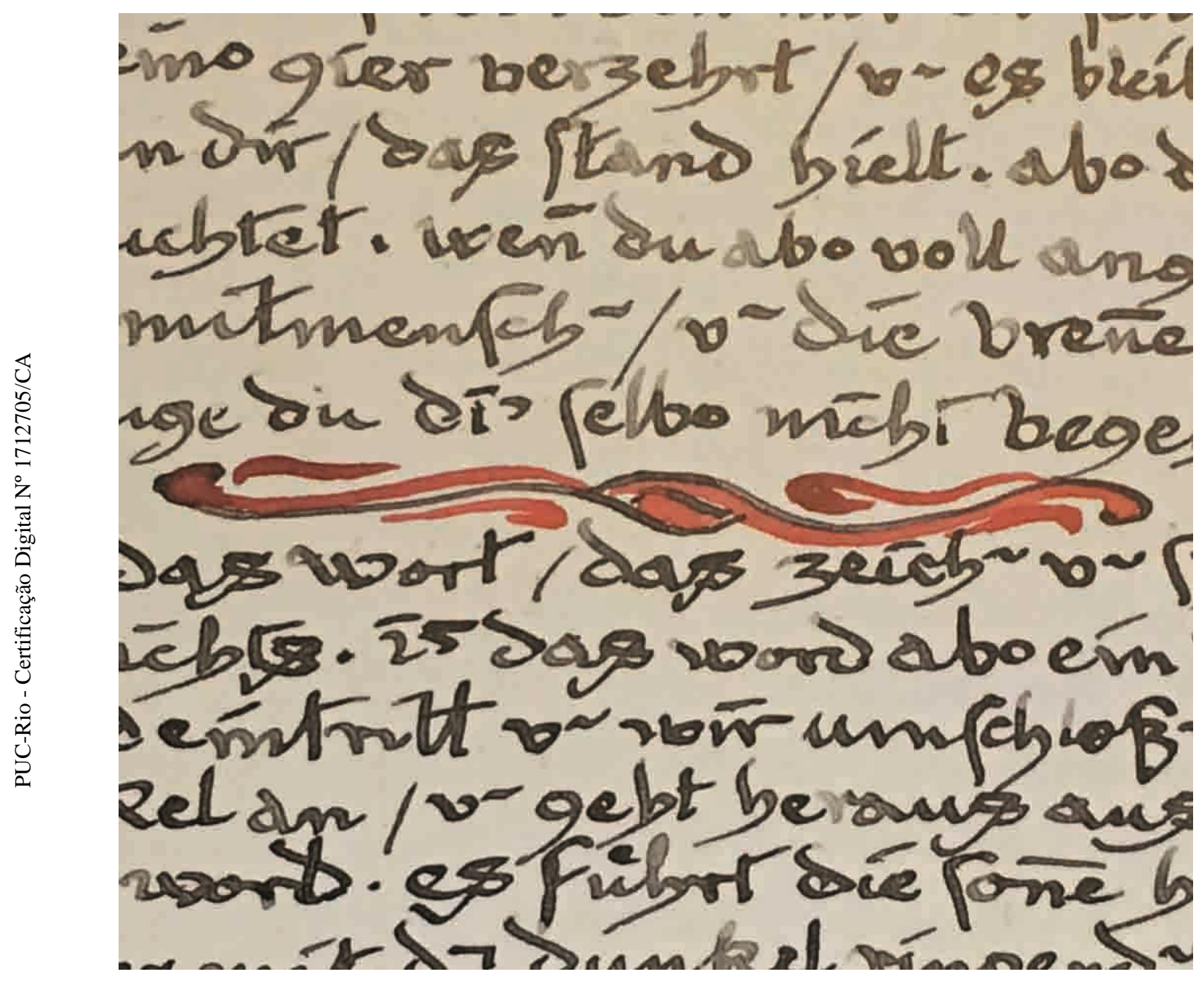

Figura 13: Detalhe de caligrafia gótica

Quase lemos, quase entendemos o que está escrito, mas queremos ser iludidos pela beleza e esquecemos que são letras e palavras. [...]. O espectador não precisa decifrar e codificar o

\footnotetext{
${ }^{201}$ Idem.

202 Idem.
} 
que está escrito, tudo é imagem. Será uma forma de silenciar as palavras? Ou o contrário? ?03 $^{20}$

A caligrafia de estilo gótico (ou escolástica) nome pelo qual é chamada o tipo de letra angulosa e com linhas quebradas, originou-se entre os séculos XII e XIII, a partir do fraturamento paulatino das formas manuscritas da escrita carolíngea. Usada na Europa Ocidental desde 1150 até aproximadamente 1500, continuou, entretanto, a ser utilizada e valorizada em países de língua alemã até o século XX, de onde se compreende ter sido essa a escolha de Jung.

\subsubsection{Pinturas - iluminuras e inicias iluminadas ou historiadas}

As pinturas dividem-se basicamente entre o conjunto de iluminuras inseridas entre textos chamados em seu conjunto de Encantações, ilustrações, mandalas e iniciais iluminadas que desenham ainda uma história à parte, pois combinando, cada vez em si, um arranjo diferente entre linguagem, texto e imagem $^{204}$, ora são decorativas, ora extremamente complexas. A princípio pode-se pensar que o conjunto de sessenta e nove pequenas obras criadas a partir das iniciais iluminadas teria consistente relação com as passagens respectivas do texto. Mas, conforme esclarece Ulrich ${ }^{205}$, na variedade de relações que se mostram, nem sempre esse é o caso.

\footnotetext{
Algumas limitam-se à decoração de uma letra, outras são imagens mais complexas, enriquecidas com motivos pictóricos adicionais. (...) O motivo é imediatamente reconhecível, assim a referência ao texto e ao significado é clara. O motivo é imediatamente reconhecível, mas a referência ao texto e ao significado não é clara. a composição do motivo não é objetiva e um possível significado específico permanece obscuro ${ }^{206}$.
}

\footnotetext{
203 Idem.

${ }^{204}$ Idem.

${ }^{205}$ Ibid. (p 248)

${ }^{206}$ Idem.
} 


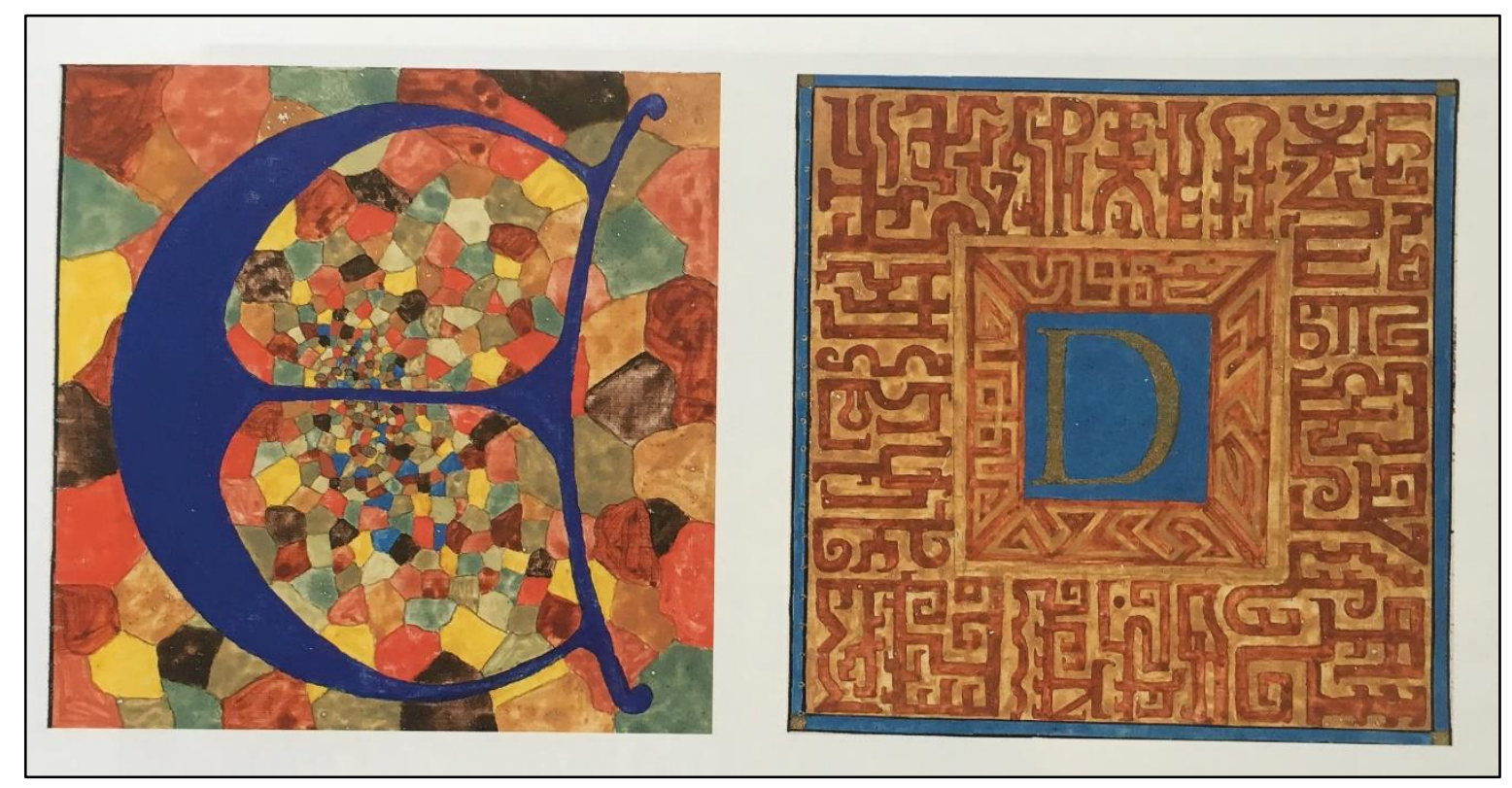

Figura 14: Iluminura p (11 e 13/ LV)

Interessante notar que as variações estilísticas - uma cena naturalista, um

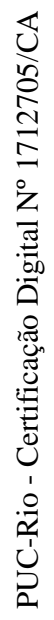
motivo do mundo real, pintado em perspectiva tridimensional; uma imagem simbólica com elementos surrealistas, pintadas realisticamente numa perspectiva bidimensional; ou ainda, uma composição abstrata, apenas formas e cores não representacionais $^{207}$ - vão ao encontro, em termos de cronologia, grosso modo, do desenvolvimento estilístico da arte moderna europeia ${ }^{208}$.

\footnotetext{
207 Idem.

208 Idem.
} 


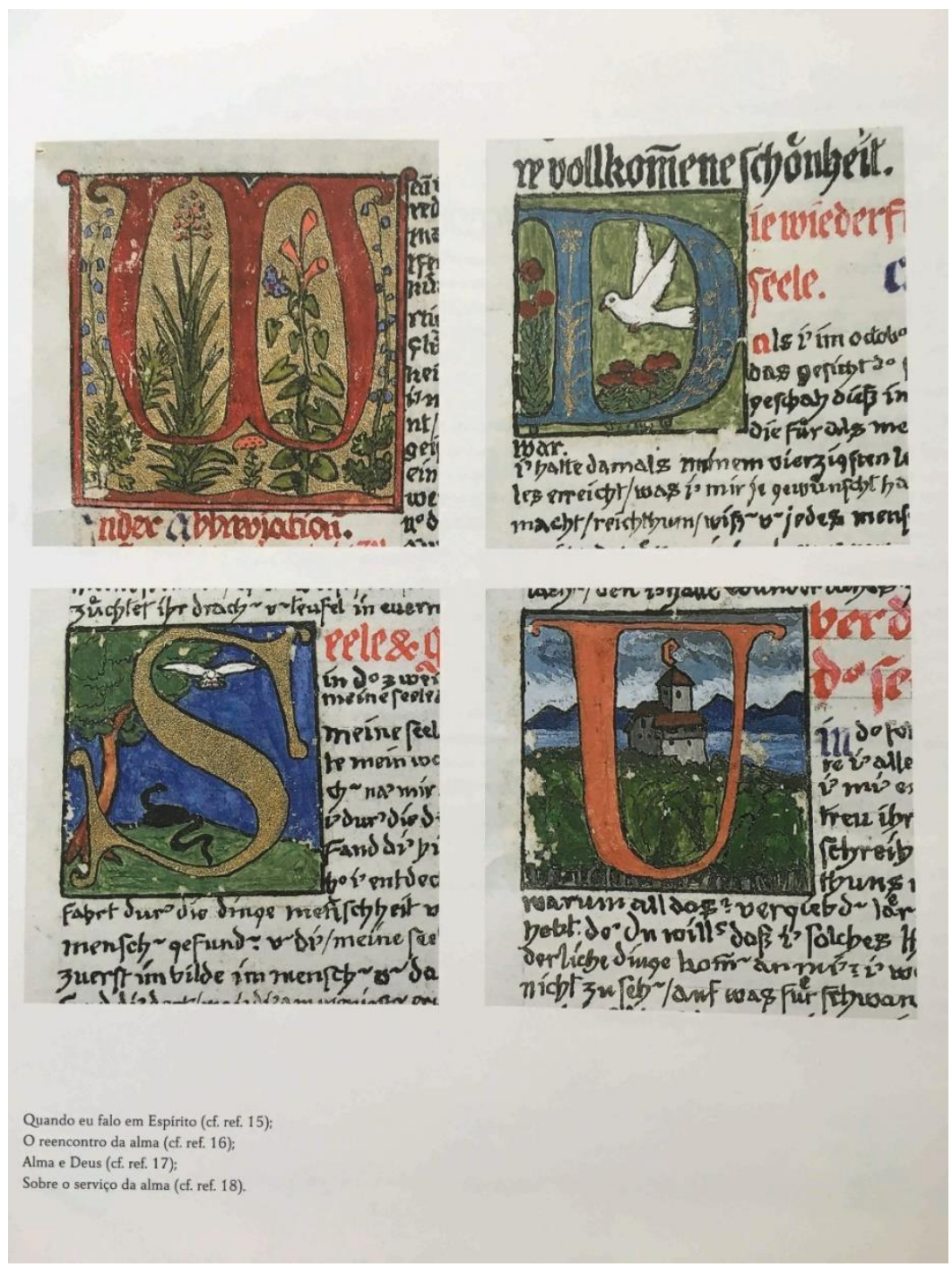

Figura 15: Iluminuras: "Quando eu falo em espírito" (fólio I/LV); "O reencontro da alma" (fólio I/LV); "Alma e Deus" (fólio II/LV); "Sobre o serviço da alma" (fólio II/LV)

Toda a pintura caracteriza-se por um jogo de transparências, opacidades e intensidades construídas com uma paleta potente e diversificada, capaz de expressar-se bem tanto com as cores primárias, secundárias e complementares, como com os matizes de tons e sobretons variados que colorem as inumeráveis células que compõem o que se poderia chamar de campos de mosaico, constituídos por áreas de preenchimento padronizadas, ora internas, ora externas, das iluminuras ${ }^{209}$. Cada uma dessas áreas possui centenas ou até mesmo milhares

\footnotetext{
209 FISCHER, HOERNI E KAUFMANN, Thomas, Ulrich e Bettina, op. cit. In “Matéria e Método em O Livro Vermelho - Descobertas selecionadas" por Jill Mellick, artista plástico, escritor e psicólogo junguiano. (2019, p 225)
} 
dessas células, que, por sua vez, apresentam uma miríade de formatos orgânicos e geométricos, pois, embora essencialmente apresentem entre três, quatro ou cinco lados, seus tamanhos são imprecisos e determinados segundo o efeito visual pretendido $^{210}$. Ou seja, "cada célula representa uma disciplina, um compromisso irrevogável, uma pintura em si mesma ${ }^{211 ",}$

Era tão experimentado e cuidadoso com sua técnica que só poderia perceber algum desvio de tinta para além do contorno do lápis quando sua coordenação mão-olho ocasionalmente falhasse em questão de milímetros. Dadas suas pequenas pinceladas $e$ as minúsculas áreas nas quais ele estava trabalhando, sua precisão é impressionante. Jung casou sua compreensão íntima - das características de cada pigmento, de cada pincel, o ligante, o excipiente e os suportes - às suas habilidades e concentração. Ele aprimorou uma convergência entre olho, mão, tinta e superfície: suas minúsculas células requeriam campos de cor perfeitamente delineados ${ }^{212}$.

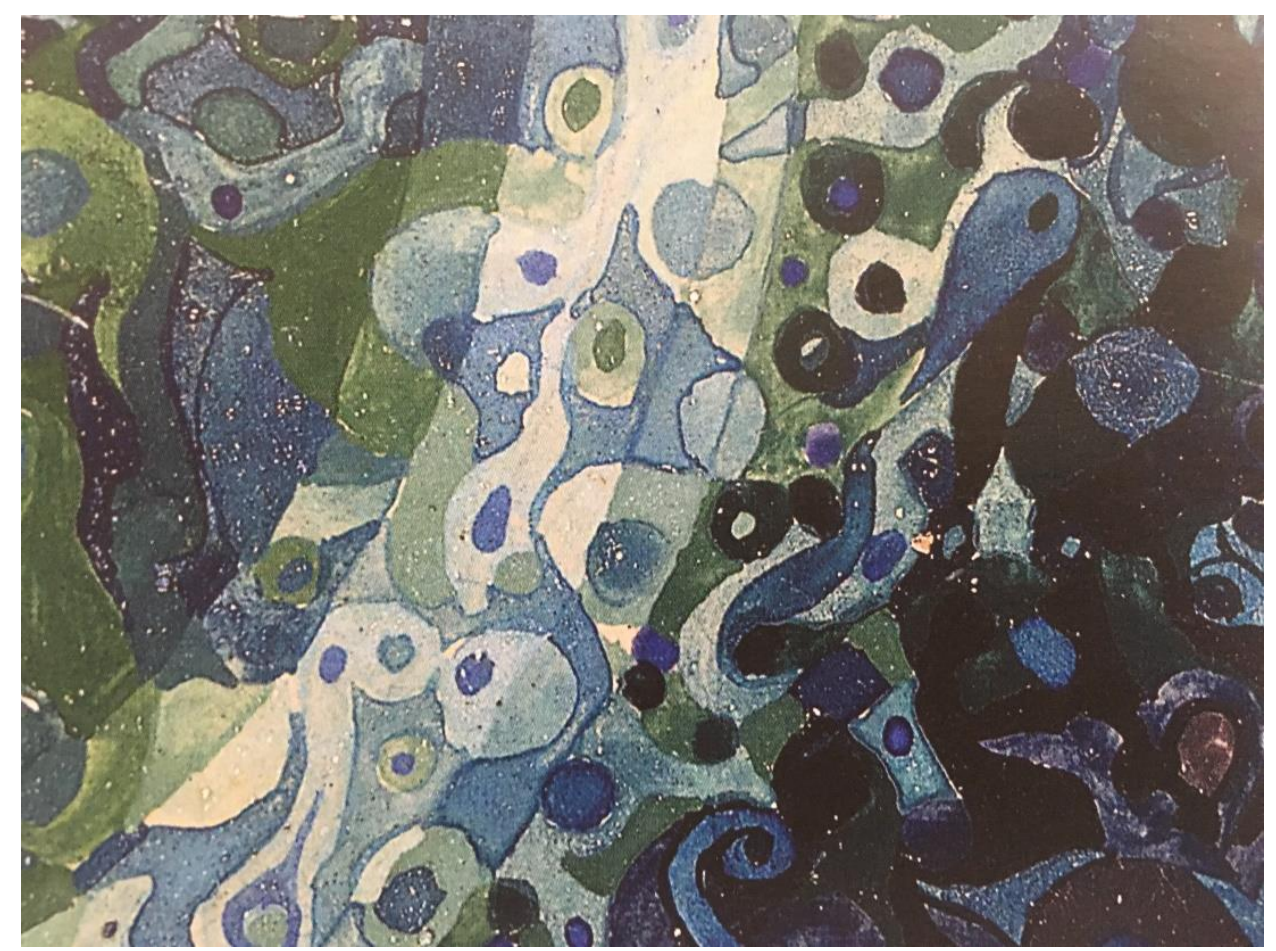

Figura 17: Detalhe de ilustração

$$
\begin{aligned}
& 210 \text { Idem. } \\
& { }^{211} \text { Idem. } \\
& 212 \text { Idem. }
\end{aligned}
$$




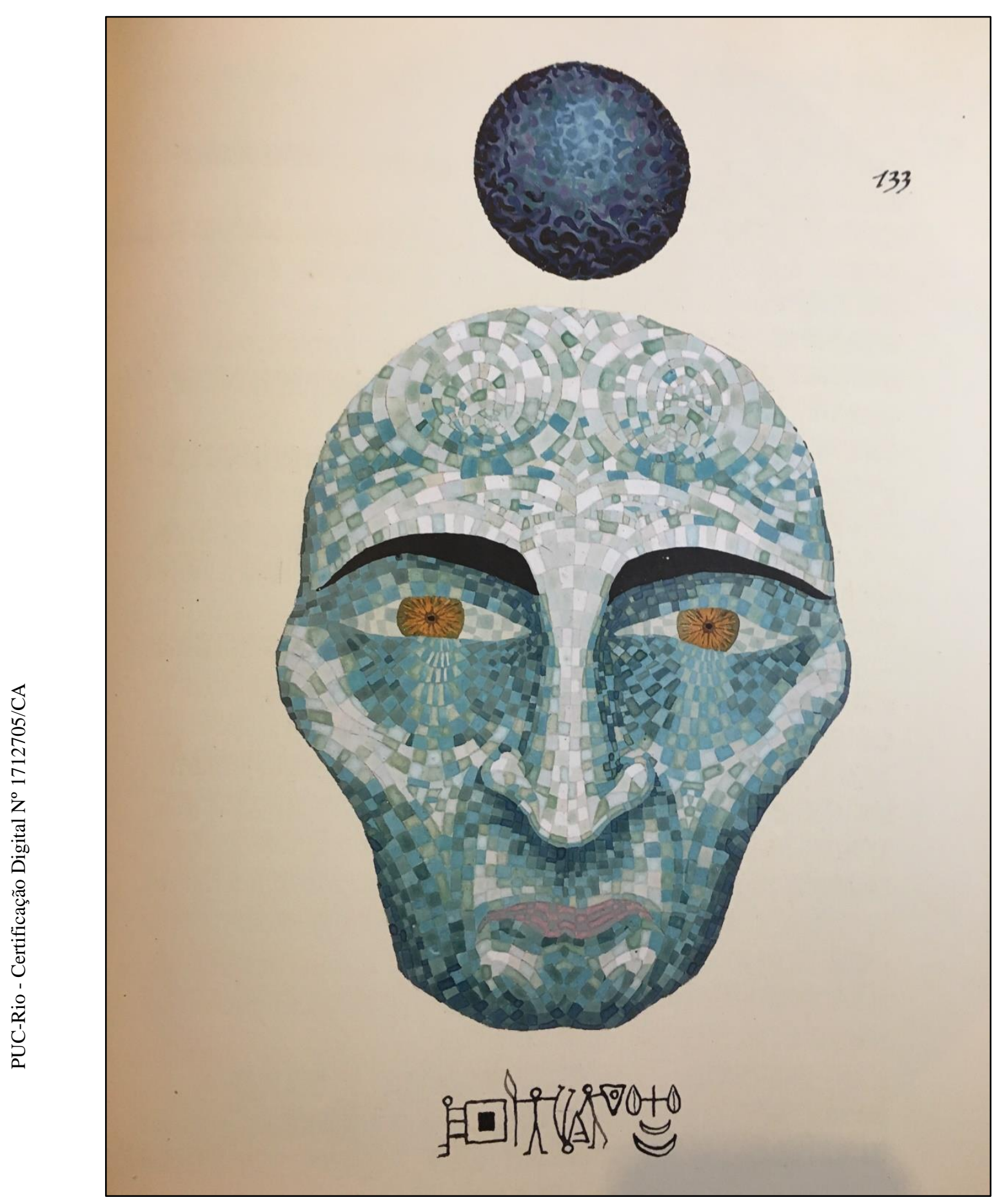

Figura 168: Ilustração “O solitário” (p 133/LV)

Percebe-se dentro da diversidade de formas - orgânicas ou geométricas tamanhos, matizes, e graus de opacidade ou transparência aplicada a cada célula, que há uma hierarquia subjacente à forma com que foram dispostas, de modo que, embora cada célula constitua-se como uma unidade em si mesma, independentemente do entorno, suas propriedades estéticas são determinantes para 
cumprir com o propósito visual pretendido ${ }^{213}$. Por exemplo, um determinado padrão de célula aumenta de tamanho à medida que se aproxima das linhas de ligação com outras áreas ou linhas de contorno, com isso obtêm-se uma irradiação central em direção às bordas da iluminura. Outra ocorrência digna de nota é a maneira como a proporção e intensidade de cada cor aumentam a cada célula, proporcionando maior foco e intensidade conforme o olho se aproxima do centro $^{214}$.

(...) é fácil perder de vista as centenas de decisões que Jung tomou para efetuar essa totalidade. Em cada campo ele variou o formato, tamanho, cor, opacidade, transparência e estilo de delineamento das células. Ele conduziu essa sinfonia de mudanças com maestria. Em nenhum momento ele fez qualquer campo de mosaico competir com as cruzes e os círculos predominantes, contudo, esses campos escuros recusam-se a ser relegados a algum tipo de espaço negativo ocupado. Ao invés disso, eles abundam em potencialização da vida; formatos e cores manifestam a forma no vazio ${ }^{215}$.

A poética de Jung distingue-se nos campos de mosaico, com toda a especificidade descrita em sua forma de composição; como também na paleta e variedade de gradações que exploram todo o espectro, do opaco ao transparente, empregado na criação de personagens arquetípicos, cenários simbólicos, iluminuras e iniciais iluminadas, permeado por um texto caligráfico que na contemporaneidade é também imagem e textura visual. Vestígios do processo linhas orientadoras, contorno, underdrawings -, característica encontrada nos já referidos manuscritos, mas também presente na obra de alguns artistas contemporâneos que desejavam reter o processo no resultado final ${ }^{216}$ compõe o resultado final, enfatizando ainda mais, a aura de presença do autor. A variedade de estilos empregados no LV - do naturalista ao rebuscado, do simbólico ao abstrato -, não traem sua autenticidade, antes comprovam a dimensão da experimentação, livre sim, mas integralmente comprometida em encontrar sua

\footnotetext{
213 Ibid. (p 226)

${ }^{214}$ Idem

${ }^{215}$ Ibid. (pp 226-227)

${ }^{216}$ Ibid. (p 224)
} 
própria expressão ${ }^{217}$. Ainda que não fora seu propósito, o resultado estético da obra exerce um grande atrativo.

[...] mesmo esses poucos aspectos das escolhas criativas de Jung - suas espetaculares cores minerais, meticuloso planejamento da caligrafia e iluminuras com aspecto de mosaico, expertise no uso de transparência e opacidade, e variada exploração da perspectiva e da dimensionalidade permitem uma compreensão mais profunda do lento, exigente, penoso, irrevogável, arriscado e disciplinado processo de feitura de O LV. Ele despendeu anos exercitando habilidades técnicas e artísticas, foco e paciência. Ao fazê-lo, tornou-se não apenas mestre e aluno de si mesmo, mas também mestre da matéria e do método ${ }^{218}$.

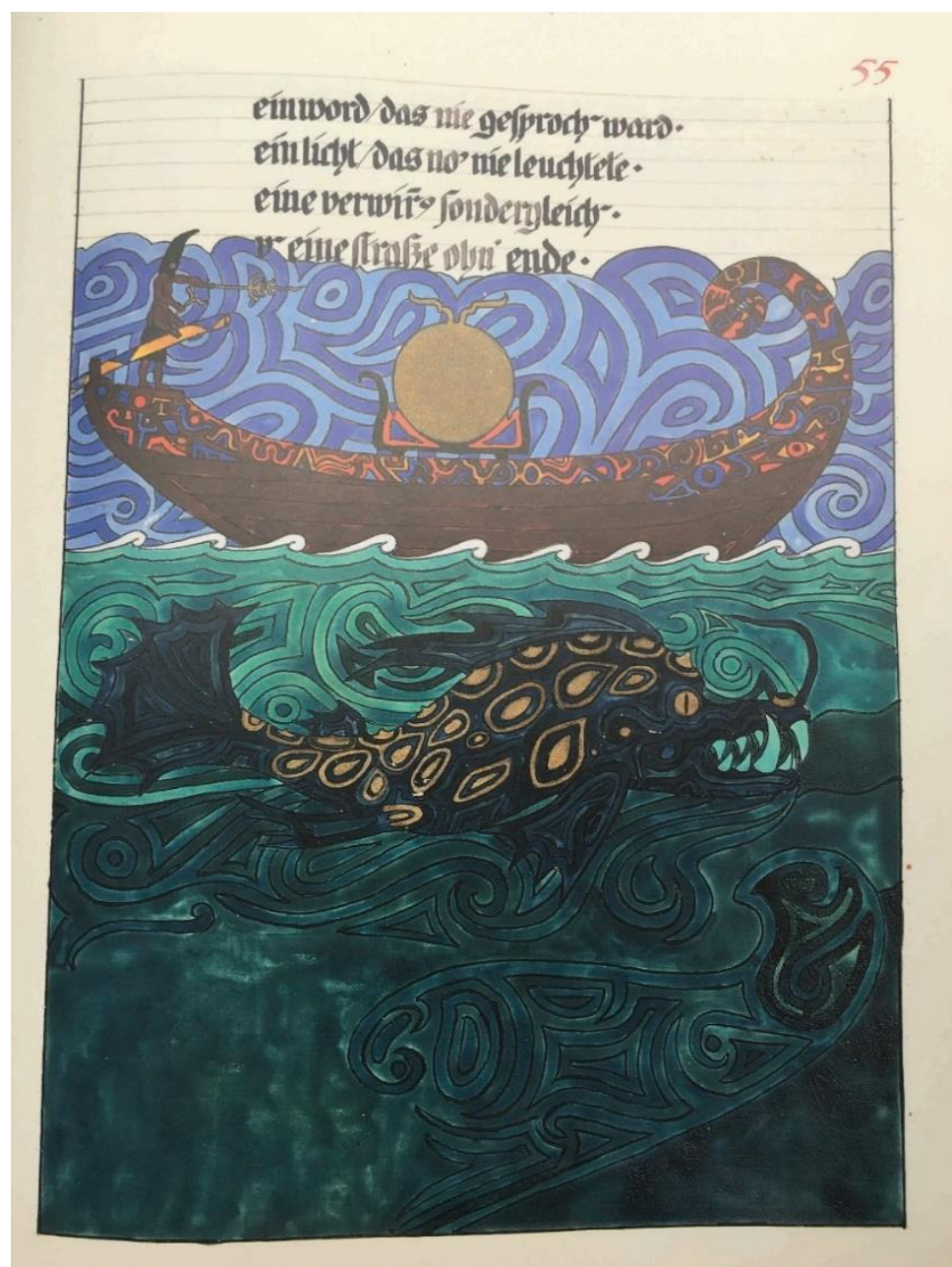

Figura 179: Ilustração sem título da série "Encantações" (p 55/LV)

${ }^{217}$ Ibid. (p 232)

${ }^{218}$ Ibid. (p 232) 

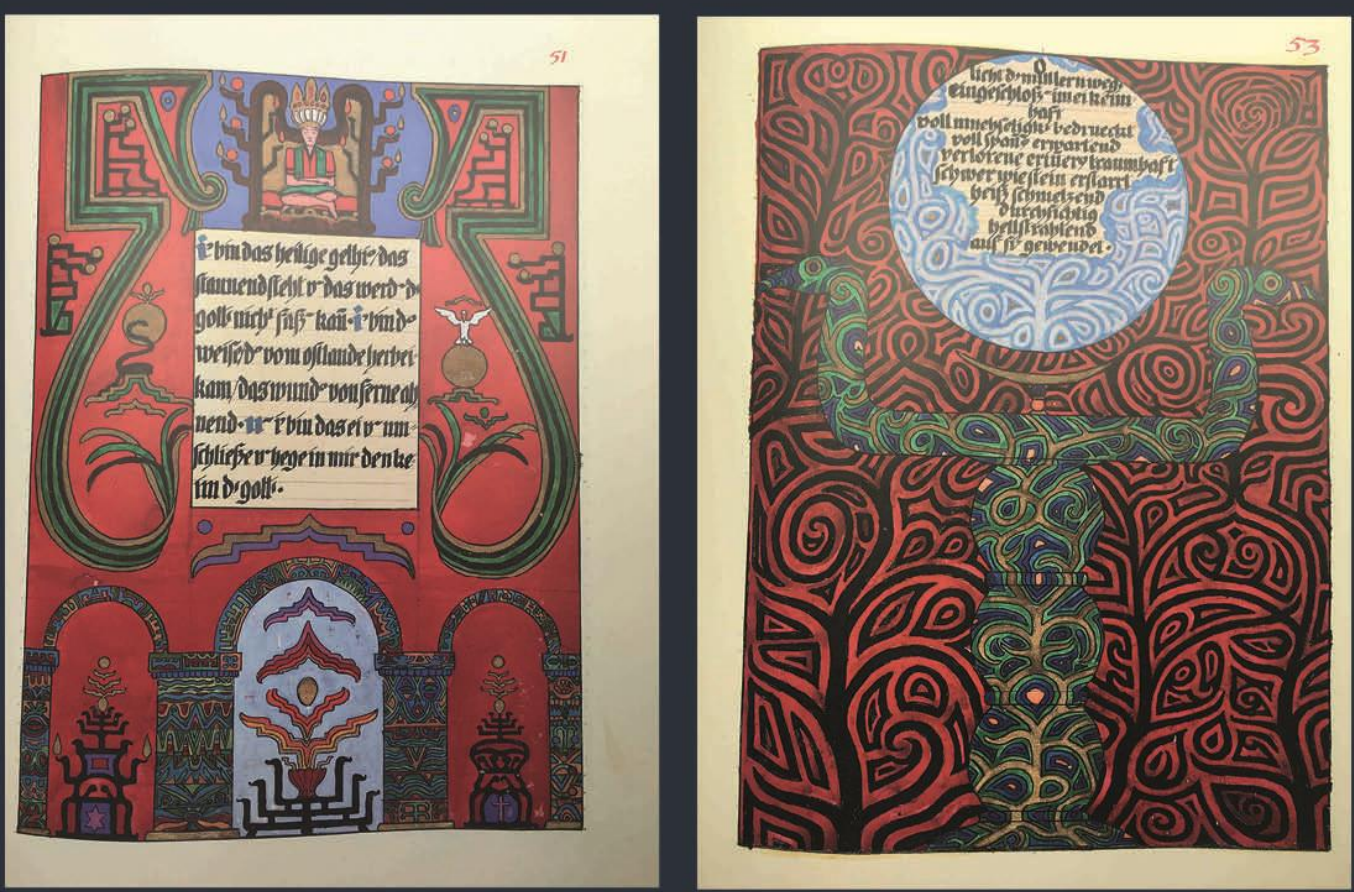

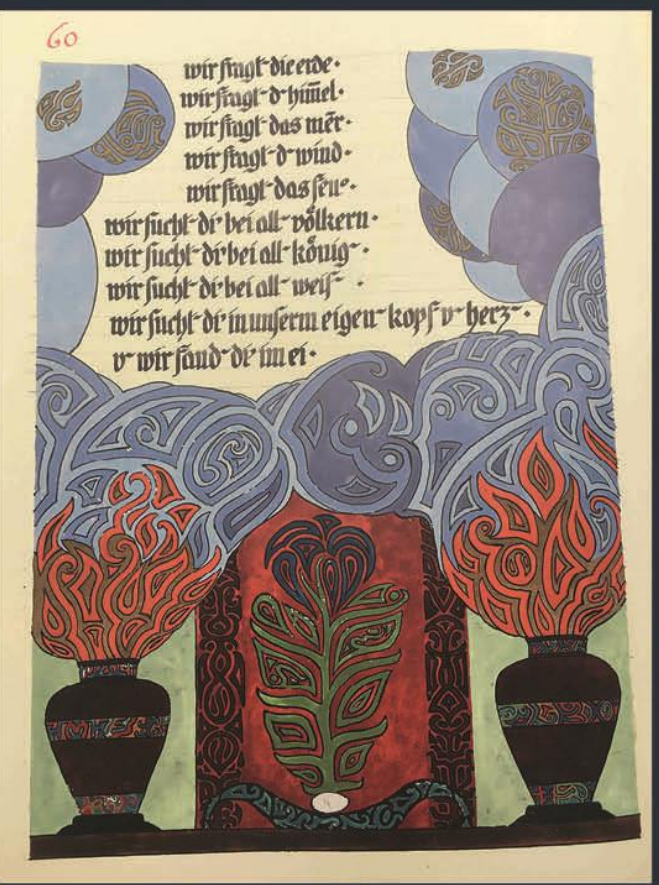

Série "Encantações"

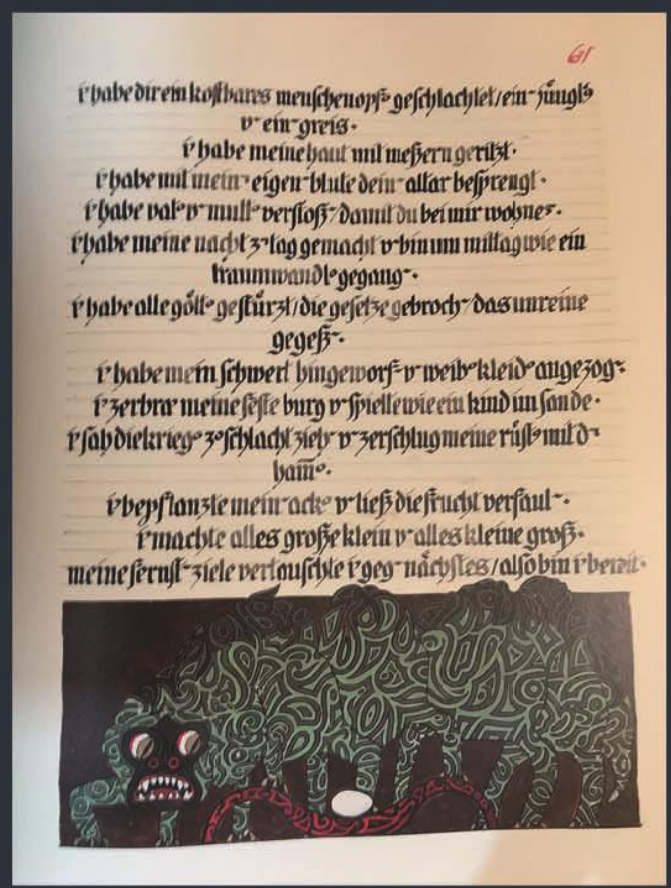

Perguntamos à terra. Perguntamos ao céu. Perguntamos ao mar. Perguntamos ao fogo.

Nós te procuramos em todos os povos.

Nós te procuramos junto a todos os reis. Nós te procuramos junto a todos os sábios. Nós te procuramos na nossa própria cabeça e coração. E nós te encontramos no ovo.

"Encantações"

Figura 2018: 


\title{
1.4.3 Linguagens - mitopoética, simbólica, profética
}

\begin{abstract}
A linguagem do Liber Novus ${ }^{219}$ segue três grandes registros estilísticos, e cada um deles apresenta ao tradutor diferentes dificuldades. Um primeiro registro relata fielmente as fantasias e diálogos interiores dos encontros imaginários de Jung, enquanto um segundo permanece firme e criteriosamente conceitual. Um terceiro registro escreve em um estilo mântico e profético, ou romântico e ditirâmbico ${ }^{220}$.
\end{abstract}

O texto apresenta diferentes possibilidades de leitura e algumas dificuldades - desde o registro inicial à elaboração conceitual e simbólica. Para Shamdasani $^{221}$, esse modo de composição estilística - única entre as obras de Jung -, teria sido fruto de sua experimentação literária e psicológica visando encontrar uma linguagem propícia para expressar, compreender e traduzir o processo em curso, pois, ao registro inicial da experiência, seguia-se o intento de compreendêla e conceituá-la. Havia ainda o propósito de formulá-la em uma linguagem que fosse capaz de dialogar e unir o que provinha do plano inconsciente com o plano consciente, pois, para Jung, todos nós estamos entre esses dois mundos - o mundo da percepção externa e o mundo da percepção interna - e, na sua visão, a união entre a verdade racional e objetiva do mundo externo com a verdade irracional e subjetiva do mundo interno, propiciava a integração e a ampliação da personalidade.

A necessidade de encontrar tal linguagem, através da qual fosse capaz de comunicar-se com suas visões e fantasias; compreendê-las; e, expressá-las dentro dessa amplitude, está no cerne da formulação criativa que originou a obra. Apresenta-se simbolicamente logo ao início, no primeiro capítulo do Liber Primus - O caminho daquele que virá -, segundo o qual Jung “percebeu que, até então,

\footnotetext{
${ }^{219}$ Jung inicialmente nomeou a obra de Liber Novus, referindo-se depois a ela como O Livro Vermelho, designação que por fim prevaleceu na publicação.

220 JUNG, op. cit. In notas de tradução da edição em alemão para o inglês. (2017, p 87)

221 Ibid. (p 88).
} 
havia servido ao 'espírito da época', caracterizado pelo uso e pelo valor", mas que, além disso, havia um 'espírito das profundezas', que levava às coisas da alma $^{222 \%}$. E essas eram as coisas pelas quais no momento ele buscava. Entretanto, Jung dá-se conta de que nos domínios de sua alma a linguagem ordinária do dia a dia já não lhe serviria ${ }^{223}$. Em meio a questionamentos e resistências, e frente a um caminho que lhe era desconhecido, ele decide então seguir o chamado do "espírito das profundezas", e, ao que parece, vai assim ao encontro da linguagem que the fora possível.

\begin{abstract}
"Depois disso calou-se meu ser humano. Mas ao meu ser espiritual aconteceu algo que preciso chamar de graça". Minha linguagem é imperfeita. Não que eu queira brilhar com palavras, mas por incapacidade de encontrar aquelas palavras é que falo em imagem. Pois não posso pronunciar de outro modo as palavras da profundeza (Ibid, p 112).
\end{abstract}

Conforme o comentário de Shamdasani ${ }^{224}$ - onde a fala falta, renova-se a capacidade de expressão, de modo que, assim como postulara Friedrich Schiller, a arte apresenta-se como caminho, pois é uma linguagem capaz de transitar por esses dois mundos. Contudo, é no símbolo, ou mais precisamente, no reconhecimento e recuperação da força de criação dos símbolos, que Jung encontra tal linguagem, pois considera que a essência do símbolo é conter o racional e o irracional $^{225}$. Por isso, na sua perspectiva, o que realmente importava não era o potencial artístico de sua produção, mas sim o alcance de sua linguagem simbólica.

De modo que "as fantasias contidas no Liber Novus deveriam ser lidas simbolicamente e não literalmente. Tirar afirmações delas do contexto e citá-las literalmente representaria um grave mal-entendido ${ }^{226}$,, pois esvaziaria a trama de relações subjetivas e dos muitos fios que tecem e refinam a experiência humana. O lugar de fala, no âmbito da intuição, dos sonhos, das visões, só pode dar conta de expressar-se lançando mão do símbolo, que, diante da impossibilidade de uma

\footnotetext{
${ }^{222}$ JUNG, op. cit. In Introdução por Sonu Shamdasani. (2017 p 44)

${ }^{223}$ Ibid. (p 87)

${ }^{224}$ JUNG, op. cit. In notas de tradução da edição em alemão para o inglês. (p 88, 2017)

${ }^{225}$ Ibid. (p 51).

${ }^{226}$ JUNG, op. cit. In Introdução por Sonu Shamdasani. (p 74)
} 
transliteração racional e literal, apresenta-se "como se" fora tal coisa, tecendo sentidos outros que a experiência não dá conta de objetivamente circunscrever.

A composição linguística encontrada preserva o que Jung considerava ser seus próprios mistérios $^{227}$, no âmbito particular, ao mesmo tempo em que permite o acesso a terceiros que sejam capazes de articulá-la com suas respectivas experiências. Caracteriza-se também como uma literatura de introspecção, não tanto no que tange ao estilo de escrita, mas pelo tom diarístico que procura registrar para si suas impressões, de modo a poder refleti-las e elaborá-las. Nesse sentido, atende ao propósito de estudar-se a si mesmo no curso do processo. Contudo, trata-se de uma introspecção em prosa dialógica, isto é, Jung dialogando com "partes de si" desdobradas nos personagens de suas fantasias. O resultado estilístico poder-se-ia conceituar então como uma literatura polifônica, sem deixar de ser simbolista e hermética, visto que os recursos metafóricos, alegóricos e simbólicos vão ao encontro da dimensão iniciática ${ }^{[1]}$ do livro, no qual o trânsito entre linguagens cumpre também com o intento de plantar certos véus, que ora revelam, ora encobrem os rastros da experiência original.

\subsubsection{O conteúdo}

O tema geral do livro é como Jung recupera sua alma e supera o mal-estar contemporâneo da alienação espiritual. Isto finalmente é alcançado possibilitando o renascimento de uma nova imagem de Deus em sua alma e desenvolvendo uma nova cosmovisão na forma de uma cosmologia psicológica e teológica ${ }^{228}$.

Essencial e simbolicamente, esta é a história que o livro nos conta - o chamado de um homem por sua alma ${ }^{229}$ (ou seria o contrário?), e a peregrinação

\footnotetext{
${ }^{227}$ Ibid. (p.91)

228 JUNG, op. cit. In Introdução por Sonu Shamdasani. (p 43)

229 “Quanto ao termo 'alma' que Jung reintroduziu na psicologia, ele não tem nada a ver com o conceito abstrato da filosofia religiosa. É um dado da experiência, uma presença existencial a si mesmo no seu relacionamento com o mundo. Embora essa vivência seja individual, é uma realidade objetiva. Ao reconhecer no fenômeno psíquico a sua objetividade, Jung coloca definitivamente a psicologia no campo das ciências". In Prefácio à edição brasileira de Memórias, Sonhos e Reflexões, por Leon Bonaventure; Doutor em psicologia e membro da Sociedade Internacional de Psicologia Analítica. Editora Nova Fronteira, 30a edição, Rio de Janeiro, 2016.
} 
de ir-se ao seu encontro. Em primeira instância acontece o desvelamento de um espírito das profundezas subjacente ao espírito da época, com o qual ele aprende que para falar as coisas da alma é preciso encontrar a linguagem propícia, pois a linguagem da alma é diferente da linguagem das coisas do mundo. A alma, o acompanha desde então, por entre diálogos e aventuras nas quais outras vozes arquetípicas surgem e são personificadas. Cada personagem que surge traz questionamentos, ensinamentos, visões, lembranças, histórias de coisas vividas e não vividas, - tal qual Filemôn ${ }^{230}$, o arquétipo do velho sábio e também o guia interior nessa jornada. Contudo, há de se levar em conta que todo o enredo vivenciado por Jung diz respeito ao seu próprio processo de individuação, de modo que, conforme ele mesmo reiterou em ocasiões diversas, não se trata de um caminho a ser seguido, mas de que cada um siga o seu caminho, único e individual. Por isso o mais importante a se considerar em relação ao conteúdo do Liber Novus, é o processo que ele representa. Por essa razão, e ainda pelo escopo de nossa pesquisa, o conteúdo do texto propriamente dito não será analisado aqui. Cabe a cada um fazer seu próprio "Livro Vermelho", isto é, seu próprio processo, que resultará, por conseguinte, em uma nova poética a cada vez, com enredos dos mais diversos.

Eu deveria aconselhá-la a registrar tudo isso da maneira mais bela que você puder - em algum livro belamente encadernado. [...] Pense nisso em sua imaginação e procure pintá-lo. Depois, quando estas coisas estiverem em algum livro precioso, você poderá ir ao livro e virar suas páginas e para você será sua igreja - sua catedral - os lugares silenciosos de seu espírito onde você encontrará renovação ${ }^{231}$.

Não por acaso, a organização e estruturação do conteúdo levaram-no a ser comparado com grandes obras da nossa história sociocultural - ao Fausto de Goethe; às Confissões, de Santo Agostinho; à A Divina Comédia, de Dante Alighieri; ao Assim Falou Zaratustra, de Nietzsche; à Odisseia, de Homero; e, ainda, ao antiquíssimo manuscrito egípcio Diálogo de um Homem Cansado e Sua

\footnotetext{
${ }^{230}$ Um dos personagens principais.

${ }^{231}$ JUNG, op. cit. In Introdução por Sonu Shamdasani. (p 69) Sugestão eventualmente dada por Jung aos seus pacientes.
} 
(Alma) $B a^{232}$-, pois em tais obras percebemos o mesmo chamado e entrega de seus atores face a emergência de tais conteúdos.

\subsection{A expertise autodidata do artista moderno na construção de uma poética}

Quando Jung decidiu-se a criar o que viria a ser seu livro precioso, selecionou as técnicas mais tradicionais e sofisticadas com o intento de dar conta da estética pretendida - a dos manuscritos medievais iluminados. Entretanto, não sendo um artista e não havendo artistas entre seus familiares e ancestrais ${ }^{233}$, onde e de que forma ele teria adquirido expertise para cartografar seu espaço interior, como fez, através da imagem e da palavra? Apesar de sua sensibilidade como fruidor e do profundo interesse na significância da arte que nele despertara desde cedo, não tinha formação acadêmica.

Em suas Memórias ${ }^{234}$ ele descreve o fascínio com que ficava horas diante de dois quadros que pertenciam a sua família, cujas pinturas eram, em sua primeira infância, referência de beleza - "De repente eu estava diante dessas figuras maravilhosas! Totalmente subjugado, eu arregalei meus olhos; não me cansava de olhar, pois nunca tinha visto nada tão belo ${ }^{235 ",}$-, assim como ficara deslumbrado quando aos seis anos fora com uma tia visitar um museu na Basileia $^{236}$; Entretanto, em seus anos de colégio foi dispensado das aulas de desenho, devido a sua suposta inaptidão, pois diante das aulas tradicionais, nas quais lhe propunham a cópia de divindades gregas, cegas e inexpressivas, fracassara completamente ${ }^{237}$.

Contudo, a frustração e angústia que sentira com sua (má) formação acadêmica inconclusa não foram suficientes para malograr o sentimento estético

\footnotetext{
${ }^{232}$ BOECHAT, op. cit. (2014)

233 FISCHER, HOERNI E KAUFMANN. op. cit. In "Imagens do Inconsciente", por Ulrich Hoerni; e "C.G. Jung como colecionador", por Thomas Fischer. (2019, pp 17 e 235)

234 JUNG. op. cit. (2016, pp 37-38)

235 FISCHER, HOERNI E KAUFMANN. op. cit. In "Imagens do Inconsciente", por Ulrich Hoerni; e "C.G. Jung como colecionador", por Thomas Fischer. (2019, pp 17 e 235)

${ }^{236}$ Idem.

237 Ibid. (p 49)
} 
que lhe aflorara desde cedo, tampouco mudaram sua percepção acerca da habilidade espontânea que acreditava possuir para o desenho, visto que, em contrapartida, tinha discernimento que tal aptidão era motivada pelos sentimentos e objetos oriundos de sua imaginação ${ }^{238}$. A formação acadêmica não lhe fez falta, Sobrava-lhe empirismo. Foi com engajamento criativo e percepção de si dentro do ato criador, fatores segundo os quais Ostrower ${ }^{239}$ distingue a criatividade humana, que Jung trilhou o caminho do artista moderno, aquele que descobre o modo de ser e fazer, fazendo e vindo a ser. À medida que buscava recursos que fossem capazes de expressar suas impressões internas com a qualidade pictórica que idealizara, desenvolveu seus próprios métodos, técnicas e materiais, ora inventando, ora inovando o que lhe era conhecido. Foi assim que adquiriu sua expertise autodidata e cumpriu seu propósito - pelo viés da experimentação ${ }^{240}$.

$\mathrm{Na}$ manufatura das tintas, por exemplo, facilmente poder-se-ia ter comprado pigmentos em pó finamente moídos para atender ao propósito de criar efeitos transparentes e semitransparentes, assim como pigmentos processados mais grosseiramente para criar efeitos opacos e semiopacos ${ }^{241}$; afinal, o artifície das iluminuras já comprava seus pigmentos de boticários ${ }^{242}$ desde há alguns séculos. Não o fez. Ainda que representasse um desafio técnico, ele preferiu comprar pigmentos minerais de alta qualidade, cujos matizes intensos aproximavam-se ainda mais da luminosidade e do brilho inspirador dos manuscritos iluminados ${ }^{243}$. Acontece que tais pigmentos eram indicados especificamente para uso em suportes firmes, como ele mesmo usara em outra ocasião na pintura de paredes, todavia, ele os aplicou em suportes flexíveis pergaminho e velino - e, apesar da descamação indesejada causada pela

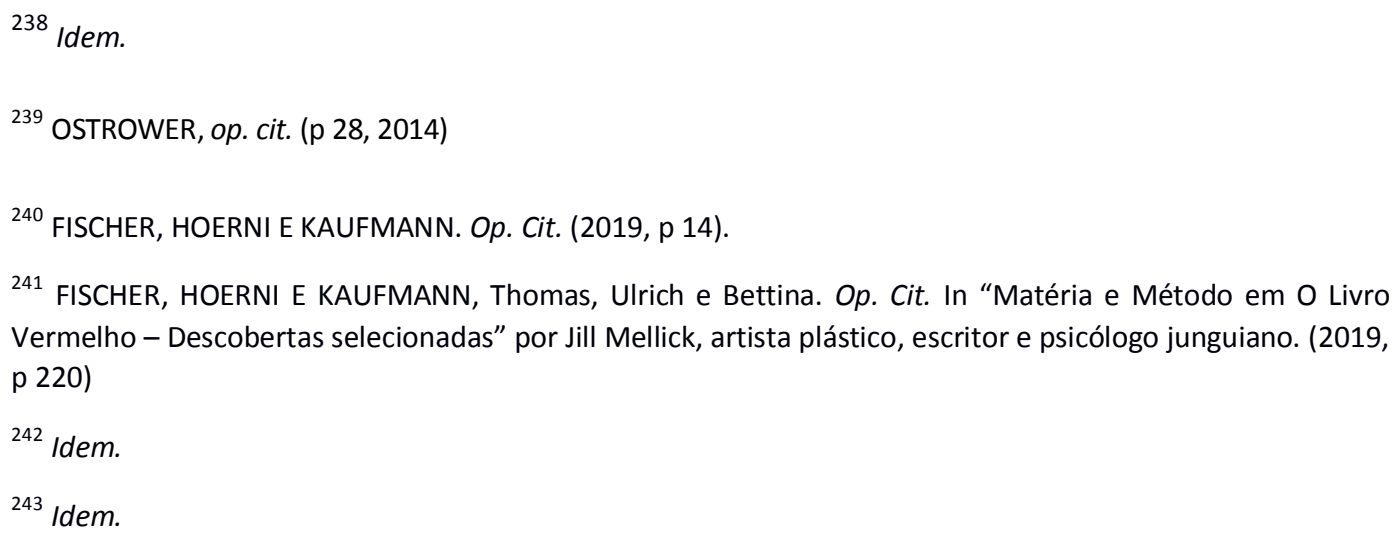


fragilidade da ligação entre o suporte e a tinta ${ }^{244}$, persistiu, até descobrir que envernizando as iluminuras minimizava os pontos fracos dos pigmentos e enfatizava seus pontos fortes ${ }^{245}$. Isto, conforme deduz Mellick ${ }^{246}$, para conjugar satisfatoriamente os efeitos que idealizara: intensidade, transparência e opacidade.

Cada materialidade abrange, de início, certas possibilidades de ação e outras tantas impossibilidades. Se as vemos como limitadoras para o curso criador, devem ser reconhecidas também como orientadoras, pois dentro das delimitações, através delas, é que surgem sugestões para se prosseguir um trabalho e mesmo para se ampliá-lo em direções novas. "De fato, só na medida em que o homem admita e respeite os determinantes da matéria com que lida como essência de um ser, poderá seu espírito criar asas e levantar voo ${ }^{247}$.

Jung era um buscador incansável, respostas prontas e insatisfatórias, não lhe serviam; por isso "pode-se presumir que preferia se arriscar ao craquelê a sacrificar a intensidade almejada ${ }^{248}$ ". Assim como na elaboração do corpo teórico de sua obra erudita, seguiu seu próprio caminho, inventando suas próprias técnicas.

Ao escolher pigmentos que não haviam sido moídos especificamente para uso em aquarela, descobriu que, usando uma carga pesada de pigmento, não apenas aumentava a saturação de um matiz - um efeito que buscou com frequência , mas também aumentava a opacidade. (...) Assim, também ele deve ter notado rapidamente que cada pigmento, com sua composição elementar única e peso específico, comportava-se diferentemente em suspensão; esses comportamentos únicos também influenciavam os efeitos que ele queria criar. ${ }^{249}$.

O arsenal organizado e utilizado para tal fim também era extremamente qualificado. Além dos pigmentos específicos que se propôs a usar, eram

\footnotetext{
${ }^{244}$ Ibid. (p 221)

${ }^{245}$ FISCHER, HOERNI E KAUFMANN, Thomas, Ulrich e Bettina. Op. Cit. In "Matéria e Método em O Livro Vermelho - Descobertas selecionadas" por Jill Mellick, artista plástico, escritor e psicólogo junguiano. (2019, p 221)

${ }^{246}$ Idem.

247 OSTROWER, op. cit. (p 28, 2014)

248 FISCHER, HOERNI E KAUFMANN, Thomas, Ulrich e Bettina. Op. Cit. In "Matéria e Método em O Livro Vermelho - Descobertas selecionadas" por Jill Mellick, artista plástico, escritor e psicólogo junguiano. (2019, p 228)

${ }^{249}$ Ibid. (p 221)
} 
necessários inúmeros outros elementos, como os ligantes para a manufatura das tintas, e demais ferramentas e artefatos; pincéis dos mais variados formatos e texturas; delineadores ou pincéis de detalhamento para obras em miniatura; canetas de caligrafia, de pelo ou com bico de metal; caneta-tinteiro para as iniciais maiúsculas; artigos de papelaria e encadernação - furador, régua, compasso, transferidor, apontador, entre outros mais específicos -, tinta spray, óleos, recipientes adequados; papéis de pano pesado de alta qualidade para os esboços, pergaminhos leves para o Liber Primus, velino pesado para o Liber Secundus.

Seu comprometimento e engajamento criativo fazem-se notar pela diversidade de competências que precisou desenvolver para, sozinho, dar conta de produzir uma espécie correlata do modelo que o inspirara, os manuscritos medievais, pois, no final da Idade Média, uma equipe de especialistas dividia o labor intenso e prolongado necessário para iluminar um manuscrito ${ }^{250}$. Jung tornou-se, ele mesmo, escriba, rubricador, ilustrador e iluminador.

Outros fatores devem ser considerados no desenvolvimento de sua expertise autodidata e na poética de suas obras visuais. Jung foi um homem culto, leitor voraz e grande pesquisador. Em sua biblioteca pessoal constava um multifacetado acervo de livros sobre arte e história da arte ${ }^{251}$. Havia, por exemplo, um catálogo sobre o pintor simbolista Odilon Redon ${ }^{252}$, provavelmente seu conhecido quando, na primeira década de 1900, ele esteve em Paris ${ }^{253}$; e obras de dois grandes coloristas da arte moderna, Paul Klee e Augusto Giacometti, que, segundo consta, Jung conheceu pessoalmente ${ }^{254}$. Tais referências são pontos fortes na poética simbolista de Jung, e em sua paleta de cores, extremamente colorida e contrastante. Em algumas de suas paisagens, inclusive, nota-se que a cor exercia um papel para além da mera representação, remetendo à tônica da paleta de cor expressionista na qual o papel da cor fora protagonista ${ }^{255}$. Ademais,

\footnotetext{
${ }^{250}$ Ibid. (p 221)

${ }^{251}$ Idem.

252 Odilon Rendon é considerado uma das maiores expressões da pintura simbolista; sua poética aproximouse e influenciou, conceitual e formalmente, a vanguarda surrealista.

253 JUNG, op. cit. In Introdução por Sonu Shamdasani. (2017, p 30)

${ }^{254}$ Idem.

${ }^{255}$ FISCHER, HOERNI E KAUFMANN, Thomas, Ulrich e Bettina, op. cit. In "Os conceitos de cor de C.G. Jung no contexto da Arte Moderna" por Thomas Fischer e Bettina Kaufmann. (2019, p 37)
} 
ele mesmo reconhecia possuir, além da aptidão para o desenho imaginativo, um senso de cor apurado ${ }^{256}$. Sua paleta, assim como as figuras bidimensionais, sem perspectiva, e os campos de mosaico que cobriam as formas orgânicas e geométricas que ele desenhava, teria sido influenciada também pela profunda impressão que lhe causaram os afrescos e mosaicos de Ravena, no norte da Itália, visitados em $1910^{257}$.

Outra coisa que não se pode desprezar é a experiência advinda do contato direto com a arte moderna, tanto através da própria fruição, quanto do entrelaçamento de seu círculo social com artistas e intelectuais que pertenciam ao avant-garde $e^{258}$. Nos anos em que esteve em Paris e Londres (1902-1903), estudou livremente aspectos visuais e estéticos da arte, e começou a pintar aquarelas.

Quando estive em Paris, eu ia ao Louvre quase todo dia, e observei La Gioconda não sei quantas vezes. (...) Por um ano inteiro fui consumido pela arte. Antes de voltar para Burghölzli. Então não tive mais tempo. (...) Eu me inteirei da arte egípcia no Louvre. (...) Eu fui aos museus em Paris até o limite da exaustão e absorvi as obras de arte em mim mesmo ${ }^{259}$.

Nesse momento, precisamente, a cena artística era confrontada pelos primeiros movimentos da arte moderna. Depois, nas décadas de 1910 e 1920, o Cabaret Voltaire, o Clube Psicológico, e suas interfaces, nas quais Jung estava inserido, desempenharam um papel importante na vida cultural da cidade ${ }^{260}$. Zurique era então uma estufa da arte moderna e serviu de palco aos dadaístas e à arte de toda a Europa ${ }^{261}$.

O sentido da pintura e da poesia modernas era intensamente debatido no clube psicológico, e vários membros, como Jung, em seu experimento com o LV buscavam forma de expressão artística para suas experiências interiores ${ }^{262}$.

\footnotetext{
${ }^{256}$ Ibid (p 38)

${ }^{257}$ JUNG, op. cit. In Introdução por Sonu Shamdasani. (2017, p 30)

${ }^{258}$ FISCHER, HOERNI E KAUFMANN, Thomas, Ulrich e Bettina. op. cit. In "C.G. Jung e a Arte Moderna” por Thomas Fischer e Bettina Kaufmann. (2019, p 26)

${ }^{259}$ Ibid. In "Imagens do inconsciente" por Hoerni Ulrich. (2019, p 17)

${ }^{260}$ Ibid. In “C.G. Jung e a Arte Moderna”, por Thomas Fischer e Bettina Kaufmann. (2019 p 26)

${ }^{261}$ Ibid. In "Os conceitos de cor de C.G. Jung no contexto da Arte Moderna", por Thomas Fischer e Bettina Kaufmann. (2019, p 21)

${ }^{262} \operatorname{Ibid}(2019$, p 26)
} 
Ainda que sua atitude frente à arte moderna tenha sido ambivalente, e apesar da incompatibilidade com algumas de suas expressões ${ }^{263}$ - o Cubismo, por exemplo -, o profundo interesse pelo campo da arte certamente o tornou vulnerável às influências que dominavam a cena. Ademais, de acordo com seu postulado sobre o inconsciente coletivo, ele mesmo deveria ser permeado pelos influxos da época.

Aos olhos de Jung, uma obra de arte não existe como expressão singular, mas é, antes, uma manifestação do fundamento inconsciente de uma pessoa ou de todo uma cultura; nesse sentido ele uma vez afirmou, a arte serve como um instrumento para expressar a psique coletiva ${ }^{264}$.

De modo que, nas experimentações criativas de Jung havia uma tônica contemporânea favorecida pela afinidade com suas próprias habilidades naturais, que se mostrara incompatível com os métodos tradicionais. Um ponto de convergência digno de nota foi a descoberta de Jung em suas pesquisas de cultura comparada e psicologia profunda, da mesma fonte incomum que inspirou os artistas modernos - a arte dos "primitivos" ${ }^{\text {,265 }}$. Outro ponto forte, no contexto da arte moderna, eram as experimentações artísticas, psicológicas e literárias que caracterizaram vários de seus movimentos - o entrelaçamento de experimentações artísticas e psicológicas com escrita literária -, traço fundamental da poética junguiana 266 .

Enfim, a arte desempenhou, em diversos âmbitos, papel vital em sua vida e obra. A começar pela fruição espontânea motivada tão somente pelo juízo de gosto que lhe aflorara ainda criança, passando pelo colecionador que se iniciara na juventude, no pesquisador que se consolidara com a maturidade; e, por fim, no

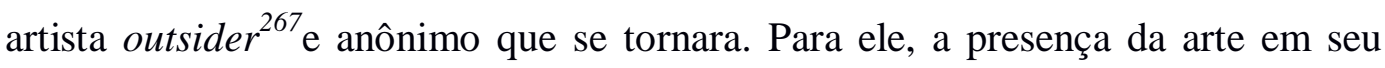

\footnotetext{
${ }^{263}$ Ibid. In "C.G. Jung e a Arte Moderna”, por Medea Hoch. (2019, p 35)

${ }^{264}$ Ibid. In "Imagens do inconsciente", por Hoerni Ulrich. (2019, p 17)

${ }^{265}$ Ibid. In “C.G. Jung e a Arte Moderna”, por Thomas Fischer e Bettina Kaufmann. (2019 p 25)

${ }^{266}$ Ibid. In "Imagens do inconsciente", por Hoerni Ulrich. (2019 p 16)

${ }^{267}$ Ibid. (2019 p 12)
} 
cotidiano era-lhe indispensável, necessária mesmo, como contraponto à dor e à loucura.
Em minha vida isolada e lotada de trabalho, (eu tenho) uma necessidade indescritível do belo e do elevado; se eu tenho ao longo de todo o dia, de encarar o trabalho da destruição da psique e do corpo, e tenho de imergir em todos os sentimentos dolorosos, de tentar penetrar processos mentais frequentemente abomináveis e torturados, eu preciso, à noite, de algo do nível mais alto da natureza ${ }^{268}$.

Não por acaso, foi objeto de seus escritos e seminários, sendo referenciada com propriedade. O ponto de convergência entre sua obra erudita e sua obra criativa, é a questão da imagem que permeia tanto o campo da arte como o da psicologia. Nessa interseção encontra-se seu objeto. Contudo, sua produção de obras visuais foi mantida em âmbito estritamente particular ${ }^{269}$, de modo que a face artística de Jung permaneceu oculta durante toda a sua vida.

Atualmente, devido ao interesse despertado desde a publicação do LV, suas obras visuais podem ser constatadas no inventário ${ }^{270}$ de mais de cem itens, para além do LV (individualmente o trabalho mais importante), incluindo pinturas, esculturas, mandalas, desenhos e projeto arquitetônico. De acordo com a classificação cronológica e temática levantada acerca dos trabalhos visuais de Jung, foram identificadas fases distintas que revelam características e interesses diversos - desenhos de fantasias, castelos e cenas de guerra a bico de pena ou lápis grafite (1885-1995); paisagens em aquarelas, guache ou pastel, algumas dentre elas caracterizadas por uma paleta de cores expressionista ${ }^{271}$ (1895-1905); esboços a lápis de grafite, tinta ou lápis de cor e abundante documentação arquitetônica de sua futura casa (1907-1908); imagens interiores em diversos meios, tais quais: guache e aquarela em papel e pergaminho; esculturas de

\footnotetext{
${ }^{268}$ Ibid. In “C.G. Jung e a Arte Moderna”, por Thomas Fischer e Bettina Kaufmann. (2019, pp 226-227)

${ }^{269}$ Ibid. In "Imagens do Inconsciente", por Ulrich Hoerni. (2019, p 17)

270 Em 1993, foi decidido pela Sociedade dos Herdeiros de Jung, que se deveria inventariar todas as obras visuais de Jung. Apesar da dificuldade da empreitada, pois muitas peças anônimas detinham apenas indicações indiretas, em 1998 havia sido identificadas cerca de cem itens, e, após a publicação do LV, esse número aumentou.

271 Segundo fontes publicadas e não publicadas, vários desses desenhos foram realizados durante sua estadia em Paris entre 1902 e 1903. (HOERNI apud JAFFÉ, 2019, p. 14).
} 
madeiras pintadas; mandalas; e, como produção mais importante dessa época, $O$ Livro Vermelho (1915-1928); itens específicos executados em vários meios frequentemente incluindo alusões literárias, tais quais: papel, madeira, pedra; e o brasão familiar (19920-1961); a Torre de Bollingen, projeto arquitetônico incluindo construção e decoração, com pinturas murais e afrescos, esculturas de pedra e relevo, realizados desde a fundação da primeira pedra às diversas ampliações que se deram (1923-1958) -, revelando um engajamento criativo que perdurou 73 anos dos seus 86 anos vividos. 


\subsection{Da edição e publicação}

A verdade é que muito antes de se pensar nos critérios da edição e publicação propriamente dita, houve muitas deliberações e pesquisas realizadas para se chegar a uma conclusão quanto a qual seria o desejo de Jung a respeito de publicação. E foram muitas as controvérsias. Ele próprio tinha dúvidas sobre o que fazer com esse material, e ainda que tenha pensado efetivamente em publicar o LV, nunca deu os passos necessários. "Em 1957, Jung declarou que os Livros Negros e o Livro Vermelho eram registros autobiográficos que ele não queria

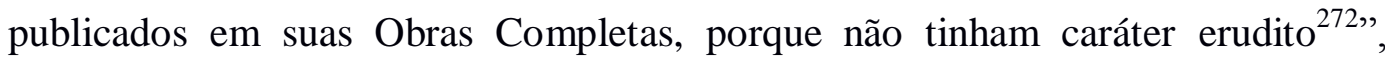
Contudo, Hoerni ${ }^{273}$ considerou que a partir da importância que a história da psicologia veio adquirindo desde Jung, a publicação desse material poderia oferecer uma nova abordagem. Ele então entrou em contato com Shamdasani:

Em longas conversas discutimos a possibilidade de ulteriores publicações de Jung, tanto em termos como no que diz respeito ao Livro Vermelho. O livro surgiu num contexto específico com o qual um leitor do século XXI já não está mais familiarizado. Mas um historiador da psicologia seria capaz de apresentá-lo ao leitor moderno como um documento histórico. Com a ajuda de fontes primárias, ele poderia encaixá-lo no contexto cultural de sua gênese, situá-lo na história da ciência e relacioná-lo com a vida e as obras de Jung. Em 1999, Sonu Shamdasani elaborou uma proposta de publicação seguindo esses princípios orientadores. Com base nessa proposta, a Sociedade dos Herdeiros decidiu na primavera de 2000 - não sem discussão liberar O Livro Vermelho para publicação ${ }^{274}$.

Entre a tomada de decisão na primavera de 2000 por parte da Sociedade dos Herdeiros de Jung em liberar a obra para publicação - após muita discussão e controvérsias - e a efetiva realização em 2009, transcorreu quase uma década. Ao contrário do que se poderia imaginar, circunscrever qual seria o público em potencial, segundo o qual seriam definidos os critérios da edição - "Leitores profissionais de obras sobre a história da psicologia? O leitor em geral? Pessoas visualmente receptivas orientadas para as imagens? Amantes das caligrafias?

\footnotetext{
272 JUNG, op. cit. In prefácio por Ulrich Hoerni. (2017)

${ }^{273}$ Idem.

${ }^{274}$ Idem.
} 
Colecionadores de belos livros?"275 -, representou um grande desafio, visto que, segundo Ulrich Hoerni, presidente da Fundação para as Obras de C.G.Jung, "até a aparência física do precioso original parecia conter uma mensagem". ${ }^{276}$ Por fim, a editora W.W. Norton propôs uma edição fac-símile completa que respeitava e mantinha integralmente as múltiplas facetas da obra, contemplando assim os diferentes tipos de público que potencialmente interessar-se-iam pelo livro. A decisão foi brilhante, e o livro difundiu-se rapidamente pelo mundo. O impacto de seu lançamento e exposição foram amplamente divulgados pela mídia internacional. A matéria publicada no dia 07/10/2009 pela Folha de São Paulo, via agência France Press, informa bem as circunstâncias e a importância de tal evento. Abaixo, a título de ilustração, transcrevemos parte dos principais pontos da redação:

O misterioso "Livro Vermelho", do suíço Carl Jung (18751961), considerado uma das obras inéditas mais importantes da história da psicologia e conhecido apenas por alguns poucos amigos do psicólogo, foi exibido nesta quarta-feira [7/10/2009] pela primeira vez em Nova York. [...] considerado a principal fonte da obra de Jung, ficará em exibição até 25 de janeiro no Museu Rubin de Nova York, no bairro Chelsea. "O Livro Vermelho", como era chamado pelo autor, consiste em uma viagem explanatória pelo inconsciente [...] a obra tem 205 páginas escritas a mão por Jung e várias ilustrações que lembram os manuscritos com iluminuras medievais. A exibição do livro coincide com a publicação em edição fac-símile bilíngue com tradução para o inglês pela editora W.W.Norton \& Company. [...] Depois da morte de Jung, em 1961, o volume permaneceu em mãos de seus familiares que se negaram a autorizar sua publicação e, inclusive, permitir o acesso a estudiosos [...] todos os psicólogos do mundo conheciam a existência desta obra [...] mas apenas algumas pessoas tinham conseguido ter acesso a seu conteúdo até essa quarta-feira. $[\ldots] .{ }^{277}$

\footnotetext{
${ }^{275}$ Idem.

${ }^{276}$ Idem.

277 Matéria postada em 07/10/2009 às 16h08, pelo Correio Braziliense via Agência France-Press. m.folha.uol.com.br/ilustrada/2009/10/634914-o-misterioso-livro-vermelho-de-jung-e-exibido-pelaprimeira-vez.shtml Acesso em 17/03/2018.
} 

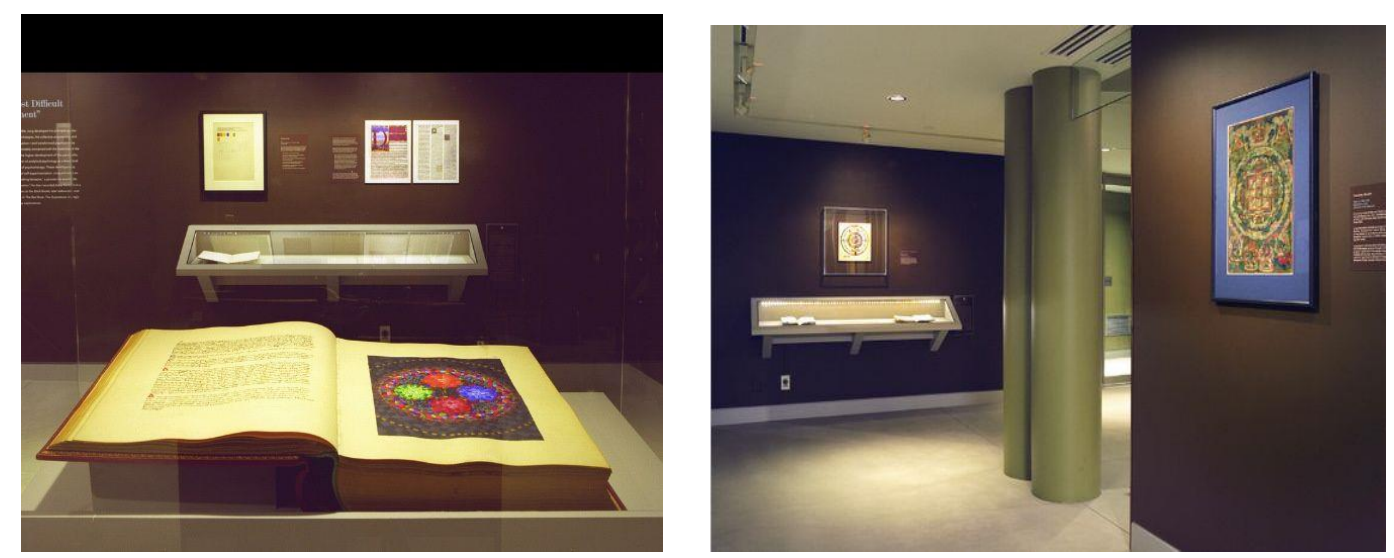

Figura21: Exposição de lançamento

Após essa primeira exposição no Museu Rubin em Nova York, outras exposições foram realizadas com seus originais: na Library of the Congress, em Washington, e no Museu Rietberg, de Zurique, na Suíça - segundo Boechat, especialmente escolhido pelos organizadores do evento devido ao grande interesse e pesquisas de Jung pela arte e cultura orientais. Em 2013, Na 55ª edição da Bienal de Veneza, o LV conquistou um lugar de destaque - ao abrir a exposição, ocupando todo o pavilhão central dedicado à Arte Outsider ${ }^{278}$.

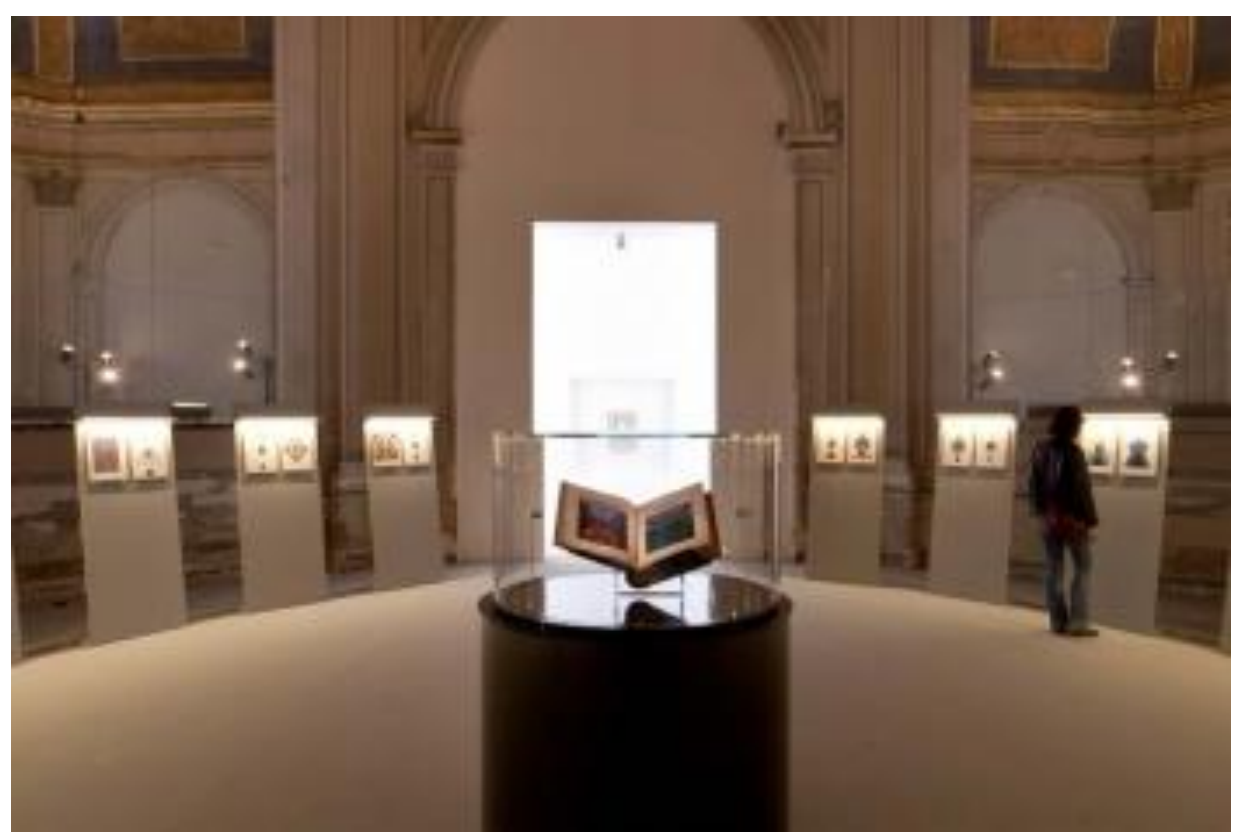

Figura 2219: Exposição na 55ª edição da Bienal de Veneza

${ }^{278}$ BOECHAT, op. cit. (2014, pp 17 18) 
No Brasil, a obra foi lançada pela editora Vozes em julho de 2010. Em agosto do mesmo ano, o departamento de Psicologia da Universidade de São Paulo organizou um evento - Exposição itinerante d'O Livro Vermelho de Jung -, onde o original do livro seria exibido pela primeira vez entre nós. A natureza do evento suscitou as seguintes questões - "O que é O Livro Vermelho? Esse livro seria uma obra de arte para que se falasse em exposição? Seria um livro artístico, e por isso pediria, em vez de uma exposição, um lançamento? Uma autobiografia? Um diário? Cartas escritas à própria alma? Um texto psicológico e ao mesmo tempo literário?"279.

Naturalmente percebe-se, como citado por Wolfgang Giegerich ${ }^{280}$, que o LV é um livro que não é um livro ${ }^{281}$, o que equivale a dizer que embora pertencente à categoria livro, há algo a mais que desconcerta o senso comum. Por isso, "rotulá-lo de arte, pintura, narrativa, drama, diálogo, autoexperimento de psicologia ${ }^{282}$ " etc. são definições conexas que não dão conta de sua totalidade. A propósito de uma definição contundente, esta seria a de um livro raro, precioso e único, e como tal deve ser compreendido.

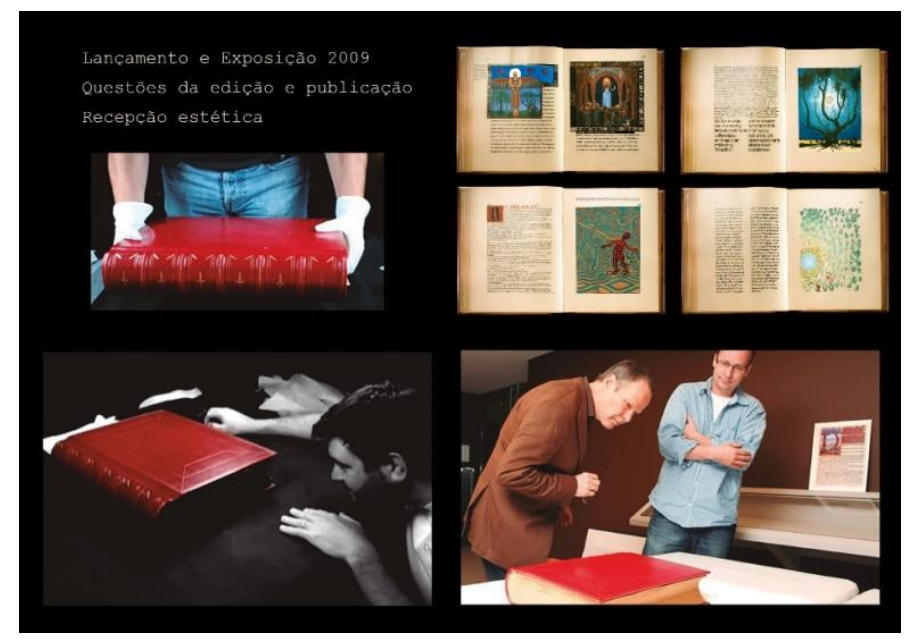

Figura 23: Retirada do LV do cofre por onde esteve guardado por décadas

\footnotetext{
${ }^{279}$ SOUZA, op. cit. $(p 25,2015)$

${ }^{280}$ BOECHAT, op. cit. $(p 45,2014)$

${ }^{281}$ Grifos meus.

${ }^{282}$ SOUZA, op. cit. (2008, p26)
} 


\title{
2. O LIVRO COMO OBRA DE ARTE - Contexto histórico e contemporâneo
}

\begin{abstract}
Assim como no poema de Bertlot Brecht, "Perguntas de um operário que lê" (1935) - Na noite em que a Muralha da China foi terminada, para onde foram os pedreiros? - às vezes nós, ao examinarmos a grande literatura do mundo devemos fazer uma pergunta similar: quem realmente $f e z$ os livros? ? $^{23}$
\end{abstract}

\subsection{Cenário contemporâneo}

$\mathrm{Na}$ contemporaneidade os livros são considerados pelo senso comum meros suportes de informação, em sua maioria fáceis de serem encontrados, consumidos e descartados. Ademais, em geral o valor econômico e cultural agregado ao livro no contexto sociocultural do século XXI é tão baixo que causa perplexidade, a ponto de Martyn Lyons ${ }^{284}$, em sua obra Livro, uma história $v i v a^{285}$, publicada no Brasil em 2011, equipará-lo ao valor atribuído a outros objetos de consumo cotidiano, como o sabão e as batatas. Segundo ele, “atravessamos uma revolução na informação que pode minar irremediavelmente o status do livro e até mesmo - segundo as previsões mais extremas - torná-lo obsoleto". Embora essa perspectiva mais radical atualmente, em 2019, já não represente a ameaça que dividiu opiniões há uma década quanto ao futuro incerto do livro impresso, uma série de fatores - mudanças nos hábitos da leitura a cada dia mais liquefeitos, entre outros - tem de fato provocado seu desvalor. No Brasil, especificamente, a crise no mercado editorial e livresco em 2018 chamou a atenção, pois, dentre diversas editoras, distribuidoras e livrarias que fecharam as portas ou encontram-se em estado crítico de sustentabilidade, a Cultura e a Saraiva, duas das maiores redes de livrarias do país, entraram com pedido de recuperação judicial; a Penguin Random House, maior grupo editorial do mundo, passou a ter o controle acionário da Companhia das Letras, editora que está entre

\footnotetext{
${ }^{283}$ LYONS, Martyn. Livro, uma história viva. São Paulo: Senac, 2011. (p.11)

${ }^{284}$ Martyn Lyons é especialista em história dos livros. Formado na Universidade de Oxford, é professor na faculdade de História e Filosofia da Universidade de New South Wales, Sydney, além de professor visitante em diversos países. Publicou diversas obras sobre história dos livros e literatura.

285 LYONS, op. cit. (2011)
} 
as melhores e maiores do país. Luiz Schwarcz, sócio-fundador, embora declare em matéria enviada à imprensa que tal negociação já era prevista desde 2012, afirmando ainda "que nada mudará na vida da Companhia das Letras", e que a decisão tem a ver com “visões de longo prazo em relação ao mercado livreiro ${ }^{286 ",}$ publicou nas principais mídias e redes sociais, por ocasião dos festejos de natal, uma carta aberta declarando seu amor aos livros e encorajando editores, livreiros, autores e todos os envolvidos na cadeia produtiva do livro a que procurassem soluções criativas e idealistas para a crise que afeta o setor, incentivando as pessoas a comprar livros como presente de natal: ${ }^{287}$

\begin{abstract}
"Cartas, zaps, e-mails, posts nas mídias sociais e vídeos, feitos de coração aberto, nos quais a sinceridade prevaleça, buscando apoiar os parceiros do livro, com especial atenção a seus protagonistas mais frágeis, são mais que bem-vindos: são necessários. O que precisamos agora, entre outras coisas, é de cartas de amor aos livros (...) Aos que, como eu, têm no afeto aos livros sua razão de viver, peço que espalhem mensagens; que espalhem o desejo de comprar livros neste final de ano, livros dos seus autores preferidos, de novos escritores que queiram descobrir, livros comprados em livrarias que sobrevivem heroicamente à crise (...) Divulguem livros com especialíssima atenção ao editor pequeno que precisa da venda imediata para continuar existindo, pensem no editor humanista que defende a diversidade, não só entre raças, gêneros, credos e ideais, mas também a diversidade entre os livros de ambição comercial discreta e os de ambição de venda mais ampla"288.
\end{abstract}

No mesmo dia, Marcos da Veiga Pereira - presidente do Snel $^{289}$, sóciodiretor da editora Sextante, e neto de José Olympio, editor e fundador da José Olympio Editora e, reconhecidamente, um dos pilares da cultura brasileira -, fez coro com Schwarcz, lançando nas redes sociais a seguinte proposta: "ir a uma livraria, comprar um livro, desafiar seus amigos a fazer a mesma coisa e postar

\footnotetext{
${ }^{286}$ Publicada pelo PublishNews, veículo que se consolidou como a voz do setor editorial e livreiro do Brasil, com publicações diárias para o setor já há 18 anos. Acesso em 19/01/2019 às $14 \mathrm{~h}$. https://www.publishnews.com.br/materias/2018/10/30/penguin-assume-controle-da-companhia-dasletras

287 Idem. https://www.publishnews.com.br/materias/2018/10/30/penguin-assume-controle-da-companhiadas-letras Acesso em 19/01/2019 às 14h.

288 Idem. https://www.publishnews.com.br/materias/2018/11/28/a-crise-nao-e-do-livro Acesso em $19 / 01 / 2019$ às $14: 45$.

289 Sindicato Nacional dos Editores de Livros.
} 
nas redes sociais" ${ }^{290}$. Nesse cenário não podemos deixar de mencionar a editora Cosac Naify - casa editorial cult, referência no mercado por seus livros de arte de luxo e produção gráfica artística e sofisticada -, que lamentavelmente fechou as portas em 2015. Segundo o sócio-fundador, Charles Cosac, a tomada de decisão ocorreu para que a linha editorial não fosse desvirtuada em função do contexto pouco favorável aos projetos culturais que justificariam a manutenção da editora $^{291}$. Apesar de estarmos descrevendo um cenário nacional, com especificidades socioeconômicas-culturais próprias, a "crise" do livro tem sido sentida pelo mundo de diversas formas. Para Lyon, o momento é propício para um balanço, no qual ele sugere "considerar a história e a evolução do livro, da produção dos escribas à página impressa, do livro em formato grande à brochura de bolso, do rolo ao códice e ao e-book ${ }^{, 292}$, pois, segundo ele, além do valor econômico e cultural, o livro "perdeu sua aura mágica"293 e recontar sua história é uma forma de resgatar seu valor e sua arte. Assim, ao surgir em meio a tal cenário com sua "aura de coisa rara e preciosa", o $L V$ provoca espanto. Ao folhear suas páginas, sem, contudo, lê-las, percebe-se nas entrelinhas o gesto e a presença do autor. Diferente de um livro industrializado e massificado, um livro como esse nos confronta com a criação e sua trama de tempo-espaço. Certamente não poderíamos comparar o valor que emana de sua aparência com um mero saco de batatas. Outrossim, livros como esse, manuscritos e ilustrados a mão, além de seu conteúdo stricto, estão impregnados de histórias - da arte, da escrita, do livro, e, por conseguinte, da nossa humanidade -, haja vista o papel preponderante que o livro tem em nossa cultura. É como estar diante de um monumento histórico: ele fala por si. Mas quantos de nós já tivemos a oportunidade de estar diante de um livro dessa espécie? ou de um manuscrito medieval?

Os mais célebres manuscritos ornados com iluminuras são, na realidade, para a maioria de nós, tão inacessíveis quanto as personalidades mais famosas. Em geral qualquer pessoa com uma

\footnotetext{
290 Idem. \#DesafioDasLivrarias Acesso em 19/01/2019 às 14:45.

${ }^{291} J o r n a l$ Época: https://epocanegocios.globo.com/Economia/noticia/2015/12/editora-cosac-naify-fechaportas.html Acesso em 19/01/2019 às 15:17.

292 LYONS, op. cit. (2011)

293 Ibid. (2011, p 8)
} 
boa dose de energia e dinheiro para viajar conseguirá ver muitos dos grandes quadros e monumentos arquitetônicos, e pode estar diante da Grande Muralha da China ou do "Nascimento de Vênus", de Botticelli. Mas tente - apenas tente - fazer com que retirem o Livro de Kells de seu estojo de vidro em Dublin para que você possa folheá-lo. Isso não vai acontecer. Atualmente, a maioria dos grandes manuscritos medievais quase nunca está em nenhum tipo de exibição pública, nem mesmo em vitrines protegidas da luz, e se estão, você verá uma única abertura de página dupla. São frágeis demais e preciosos demais. ${ }^{294}$

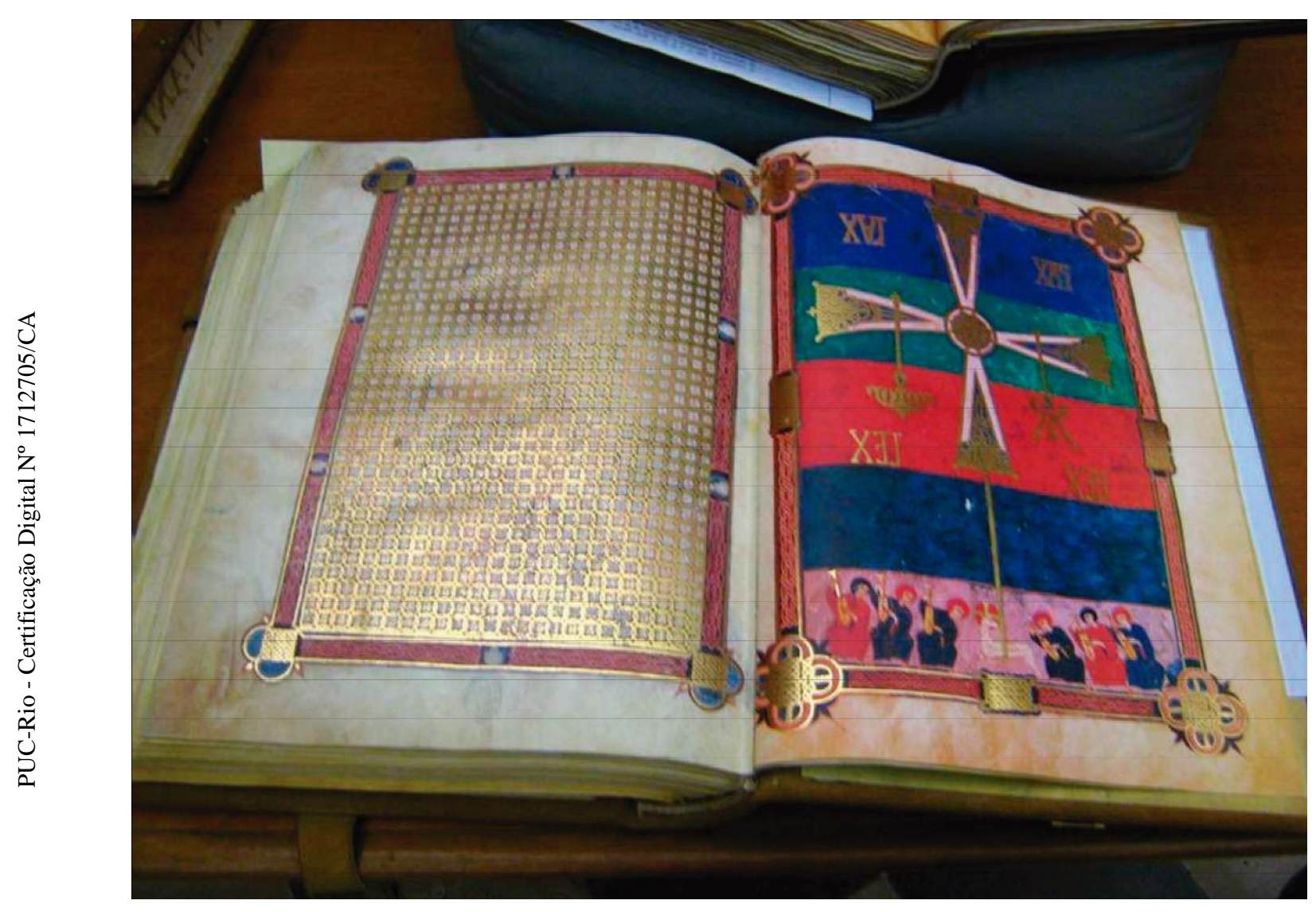

Figura 204: Manuscrito medieval iluminado

294 DE HAMEL, Christopher. Manuscritos Notáveis. São Paulo: Companhia das Letras, 2017. (p 8). Paleógrafo e autor de diversos livros sobre o tema. 


\subsection{Revisitando origens - imagens e letras}

Ignoramos como a arte começou, tanto quanto desconhecemos como teve início a linguagem. (...) Sabemos muito pouco a respeito dessas origens misteriosas, mas, se quisermos compreender a história da arte será conveniente recordar, vez por outra, que imagens e letras são na verdade parentes consanguíneos. (...) não só a feitura das imagens nessas antigas civilizações estava vinculada à magia e à religião, como era também a primeira forma de escrita ${ }^{295}$.

Para compreendermos a história da arte - e, por conseguinte, a história da escrita, assim como a do livro -, diz Gombrich ${ }^{296}$, precisamos nos lembrar que imagens e letras, com suas origens misteriosas, são parentes consanguíneos, pois, "a feitura das imagens (...) era também a primeira forma de escrita"297. Reza a máxima de Ignace Gelb, "Na base de toda escrita existe uma imagem"; isto é, subjacente à escrita existe a percepção ou a "leitura" de uma imagem, a consciência de uma Gestalt. Ao escrever "árvore", existe uma ideia, visão ou experiência de "árvore" no imaginário de quem escreve; por sua vez, a leitura de "árvore" vai engendrar sentidos outros no imaginário de quem lê, indo ao encontro da ideia, visão ou experiência de "árvore" desse leitor. Existe, claramente, relação intrínseca entre essas duas formas de expressão radicadas na experiência originária que as produziu. Jung diferencia dois tipos de pensamento o pensamento direcionado e o pensamento de fantasia -, o primeiro verbal e lógico, exemplificado pela ciência; o segundo, passivo, associativo e imagético, exemplificado pela mitologia. ${ }^{298}$ Por conseguinte, ao expressar-se por meio de algum registro, cada um desses pensamentos vai desdobrar-se mais naturalmente em letras ou imagens. O que queremos ressaltar, sobretudo, ao revisitar tais origens e refletir sobre seu parentesco, afinidade, reciprocidade, enfim, o diálogo e

\footnotetext{
295 GOMBRICH. A História da Arte. Rio de Janeiro: LTC, 16ạ edição, 2015. (p.39)

296 Idem.

297 Idem.

298 JUNG, op. cit. In “Introdução", por Sonu Shamdasani. Petrópolis: Vozes, 2017. (2017, p 12)
} 
troca natural que se dá entre a escrita e a imagem, é, como bem expressou Peyré ${ }^{299}$, o quanto a pintura e a poesia se reconhecem mutuamente no livro e através dele.

Desde a Era Glacial - na Cueva de las Monedas, Espanha, passando pelas pinturas rupestres dos aborígenes australianos em Kakandu, ou nas cavernas de Lascaux no sudoeste da França - encontramos vestígios do que podemos chamar de uma primeira escrita rudimentar a partir de imagens pictóricas inscritas nos primeiros suportes naturais que o homem utilizou - as rochas e as pedras ${ }^{300}$.

As primeiras representações gráficas que conhecemos são as chamadas pinturas rupestres - existentes há aproximadamente 32.000 anos - e os petroglifos, desenhos gravados em pedra. Essas representações não são caracterizadas como escrita, mas já se constituem numa forma positiva de comunicação e de registro. Em outras palavras, são os primeiros esboços representativos da linguagem oral ${ }^{301}$.

Tais registros e expressões, oriundos das impressões apreendidas e suas memórias, são intrínsecos e originários da natureza humana, sua história contanos a nossa história. Portanto, independentemente de seus propósitos arcaicos comunicação, magia, religião, armazenagem de conhecimento, embelezamento etc. -, o que os distingue afinal - imagens e letras -, não é sua essência ou origem, mas o papel que cada um veio ocupar segundo as características próprias que se vieram desenhando em sua evolução.. É como a água nascente que brota das profundezas da montanha, e em seu fluir e crescer transborda em várias direções, transformando-se em rios, que em seu caminhar criam diferentes paisagens, e, entretanto, desaguam na imensidão do mesmo mar.

A escrita propriamente dita - a começar pelas primeiras evidências de pensamento simbólico, marcas em pedras e ossos encontrados na caverna Blombos da África do Sul, datados de cerca de cem mil anos atrás, indicando entalhe proposital para armazenagem de informação - só se tornou um sistema completo no momento em que o símbolo tornou-se signo e a "arte gráfica

\footnotetext{
${ }^{299}$ PEYRE, Yves. Peinture et Poésie - le dialogue par le livre 1874-2000. Paris: Editions Gallimard, 2001.

300 FISCHER, Steven Roger. História da Escrita. São Paulo: UNESP, 2009. (pp 18-33). Fischer é diretor do Institute of Polynesian Languages and Literatures em Aukland, Nova Zelândia; Linguista a mais de trinta anos, dezoito dos quais dedicados à escrita antiga e deciframento de inscrições antigas.

301 MEREGE, Ana Lucia. In "História do Livro Manuscrito". IBICT-UFRJ/ECO. Bibliotecária do setor de manuscritos da BN, mestre em ciência da informação. ( $p$ 1)
} 
começou a falar", isto é, quando houve uma exploração consciente do fonográfico no pictográfico. Isso se deu por volta de 4000 a.C., a partir da escrita cuneiforme $^{302}$.

Tal sistema não surge da noite para o dia. A história da escrita é longa, lenta e complexa. História que se confunde, se entrelaça com a história do próprio homem, um romance apaixonante do qual nos faltam, ainda hoje, algumas páginas ${ }^{303}$.

Poder-se-ia, então, considerar que nesse momento no qual a escrita tornase "completa" - isto é, segundo Fischer ${ }^{304}$, quando a escrita passou a preencher os seguintes requisitos: "tinha como objetivo a comunicação; consistia de marcas gráficas artificiais sobre um suporte durável; e usava marcas voltadas convencionalmente a articular a fala de maneira que a comunicação fosse alcançada" -, ela marca sua distinção como forma de expressão por excelência para transmissão do pensamento, abrindo caminho para o que hoje chamamos de literatura.

Essa escrita apareceu na Suméria, ao sul do atual Iraque, e consistia, inicialmente, em sinais e números produzidos pela ação de pressionar uma cunha sobre tabuletas de argila mole, que depois simplesmente secavam ao sol ou eram cozidas no forno. Devido a isso ficou conhecida como cuneiforme. Ao contrário do que se costuma romancear, tais tabuletas inicialmente serviam à burocracia da época para fazer e registrar contas e contratos jurídicos. Entre os mais antigos vestígios catalogados da história da escrita está uma placa de Uruk, datada do quarto milênio a.C. ${ }^{305}$ As "placas de Uruk" são constituídas de listas de sacos de grãos e de cabeças de gado, estabelecendo uma espécie de contabilidade do templo. Apesar desse primeiro sistema de escrita completa ter surgido como resposta a necessidades econômicas, ${ }^{306}$ foi a partir dela que a literatura - do latim litteratura (alfabeto, gramática) - teve início. Com o tempo as placas passaram a conter toda a literatura suméria, incluindo mitos, hinos, narrativas dedicadas aos

\footnotetext{
${ }^{302}$ FISCHER. Op. cit. (2009 p 33)

303 JEAN, Georges. op. cit. (2008, p 12)

304 Ibid. (p 14)

305 Ibid. (p 13)

${ }^{306}$ FISCHER, op. cit. (2009, p 45)
} 
deuses e, segundo Lyons, até mesmo piadas. ${ }^{307}$ Dessa forma, a escrita segue desenvolvendo sua própria história e arte, e, com o tempo, além de “"a pintura da voz' como queria Voltaire, ${ }^{308}$, veio a ser, de muitas formas, fundamental.

Tornou-se a suprema ferramenta do conhecimento humano (ciência), agente cultural da sociedade (literatura), meio de expressão democrática e informação popular (imprensa), e uma arte em si (caligrafia), para mencionar apenas algumas manifestações ${ }^{309}$.

É evidente que tal desenvolvimento só foi possível a partir de seus registros, o que pressupõe a criação de suportes materiais, através dos quais seguiu-se a evolução do que hoje reconhecemos como livro.

\footnotetext{
307 LYONS, op. cit. (2011, p 17)

308 FISCHER, op. cit. (2009, p 10)

Idem.
} 


\title{
2.3 A evolução do livro
}

\begin{abstract}
As escritas antigas foram registradas em um sem-número de suportes. Os mais famosos são as tabuinhas de argila utilizadas na Mesopotâmia, porém também se encontram inscrições em pedra (praticamente todas as que sobraram de Cartago, por exemplo), bronze, madeira, tiras de bambu e folhas de árvore. $\mathrm{Na}$ China, os primeiros escritos conhecidos, datados do segundo milênio anterior a nossa era, são textos divinatórios escritos sobre ossos e cascos de tartaruga. No Egito, a escrita hierática um tipo de escrita simplificada, mais utilizada pela classe sacerdotal, mas que também serviu para registros comerciais, administrativos e literários - foi encontrada principalmente em cacos de cerâmica, chamados de ostraca, e no material por excelência ligado à Antiguidade clássica, o papiro ${ }^{310}$.
\end{abstract}

É espantoso saber da quantidade e diversidade dos acervos constituídos com toda sorte de materiais que habitaram a ideia de livro, oriundos do reino mineral, vegetal e animal, ainda que seu propósito estivesse restrito à guarda e preservação dos livros, e não à acessibilidade e empréstimo, como hoje em dia. Os textos literários mais antigos de que se tem notícia no mundo apareceram nas mencionadas tabuletas sumerianas ${ }^{311}$, consideradas, então, como nossos primeiros "livros".

Entre meados do século XIX e início do século XX, foram descobertas 25 mil placas em Nínive, que incluíam literatura épica e interpretação de presságios (horoscopia) na língua acadiana. As placas pertenciam à erudita biblioteca do rei Assurbanipal de Nínive (668-630 a.C.), que também forneceu a versão assíria d'A epopeia de Gilgamesh ${ }^{312}$.

Gilgamesh conta a história dos feitos de um rei mítico da cidade suméria de Uruk, em busca da imortalidade ${ }^{313}$, Segundo Georges Jean ${ }^{314}$, essa epopeia prenuncia as grandes lendas da mitologia grega, mais especificamente, "Os trabalhos de Hércules"; ademais, contém "uma extraordinária evocação do

\footnotetext{
310 MEREGE, op. cit. (p 4)

311 Ibid. (p 53)

${ }^{312}$ LYON, op. cit. (2011, p 17)

${ }^{313}$ Idem.

314 JEAN, Georges, op. cit. (2008 p 80)
} 
dilúvio", prefigurando a versão que depois surge na Bíblia. Esse exemplo permitenos inferir que, naturalmente, acervos se constituíram à medida que o homem encontrava materiais e formas de registrar e salvaguardar sua expressão, memórias e histórias. Assim surgiram as primeiras bibliotecas de que se tem notícia - as chamadas bibliotecas "minerais".

Infelizmente, a maioria das bibliotecas da Antiguidade foi destruída de alguma forma; entretanto, alguns acervos raros reunidos durante o medievo ainda estão preservados entre nós, como a biblioteca do Templo de Haeinsa, na Coreia, que abriga a Tripitaka Koreana ${ }^{315}$ - uma coleção do século XIII composta por mais de 80 mil blocos de madeira gravados com escrituras budistas ${ }^{316}$-, dandonos uma ideia da diversidade de materiais e da arte envolvida na criação e produção desses acervos.

Ao seguirmos o fio da história e evolução do livro em busca de suas origens, invariavelmente nos surpreendemos com sua presença crescente nas mais diversas culturas antigas - orientais e ocidentais -, visto que, no mundo antigo, como no Egito, apenas $1 \%$ da população sabia ler e escrever, geralmente uma pequena elite de escribas, sacerdotes e nobres. ${ }^{317}$ "Segundo os antigos egípcios, foi o próprio deus Thot quem teria criado a escrita, doando-a depois aos homens" ${ }^{\text {318 }}$, e cabia aos sacerdotes a interpretação dos livros sagrados, pois o conhecimento da escrita fazia deles intermediários e porta-vozes entre a existência terrena e a vida no além ${ }^{319}$. Todavia, no $2^{\circ}$ milênio a.C. já existiam escolas para escribas que se propunham a ensinar a "esotérica arte de escrever" 320 . Uma delas foi descoberta por arqueólogos na década de 1950, em Nipur, próximo ao rio Eufrates.

O comércio e a circulação dos livros começam a desenvolver-se ainda no século IV a.C., com os rolos de papiro - suporte que se seguiu às tabuletas de

\footnotetext{
${ }^{315}$ LYONS. op. cit. (2011, p 33) Um cânone de textos budistas essenciais, surgido entre o século I a.C. e o início de nossa era; até então, os ensinamentos de Buda (V ou VI a.C.) sobreviveram via tradição oral.

316 Idem.

${ }^{317}$ Essa informação está presente em toda a bibliografia consultada para esta pesquisa.

318 JEAN, op. cit. (2008 p 27)

${ }^{319}$ LYONS. op. cit. (2011, p 27)

$320 \quad$ Ibid. (p 16)
} 
argila sumerianas -, quando surgem os primeiros livros para serem lidos, pois, até então os livros figuravam como aides-memories dos seus autores, e sua divulgação, transmissão, e leitura era sobretudo oral, o que explica a reputação e prestígio que tinham os atores, rapsodos, oradores e leitores-recitadores ${ }^{321}$. Lyons (2011) compara o papel do autor dessa época ao de um compositor musical. "Seu trabalho não estava completo até que alguém o transformasse em som e o recitasse em voz alta", isto é, a leitura para os gregos era uma performance oral ${ }^{322}$. Para Cavallo e Chartier ${ }^{323}$, "a Grécia antiga teve a nítida consciência de que a escrita fora 'inventada' para fixar os textos e trazê-los assim novamente à memória", e teria sido nas últimas décadas do século V a.C. que começam a delinear-se as fronteiras entre o livro destinado à conservação do texto e o livro destinado à leitura. Contudo, conforme Cavallo ${ }^{324}$ deduz frente aos dados imprecisos e inexistência da maioria esmagadora do acervo da época que foi pilhado, destruído ou queimado, qualquer informação quanto à quantificação de leitores, temas, tiragem das cópias produzidas, entre outros dados, é mera especulação.

Dos papiros egípcios extraem-se com certeza três conclusões: havia analfabetos que faziam com que outros tomassem a pena, havia pessoas do povo que sabiam ler e escrever, havia textos literários, clássicos, nos povoados os mais obscuros (...) todo o resto não passa de imprecisão ${ }^{325}$.

Ele ressalta, todavia, que fosse qual fosse a quantificação dessa minoria, era suficiente para manter uma produção literária e editorial diversificada. Cavallo e Chartier ${ }^{326}$ apontam a época helenística como o período em que o livro passa a ter um papel fundamental, pois, ainda que prevaleça a transmissão do conhecimento oral, toda a literatura da época passa a depender da escrita e do livro. Ocorre que a filologia alexandrina - a partir do conceito de que "uma obra

\footnotetext{
${ }^{321}$ ARAÚJO, op. cit. (2008 p 38)

${ }^{322}$ LYONS, op. cit. (2011, p 27)

${ }^{323}$ CAVALLO, Guglielmo e CHARTIER, Roger. História da leitura no mundo ocidental I. In "Introdução". São

Paulo: Ática, 1998. (p 10)

${ }^{324}$ Ibid. (Veyne apud Cavallo, p 76)

${ }^{325}$ Idem.

326 Ibid. (p 13)
} 
só existe se for escrita, obra é um texto escrito e de que podemos nos apropriar graças ao livro que a conserva" ${ }^{327}$ - transforma, então, a literatura de uma época mais antiga, que não tinha esse propósito e, por conseguinte, não havia sido assim fixada, em livros ${ }^{328}$. Aliás, o propósito da Biblioteca de Alexandria (290 a.C.) arquétipo das grandes bibliotecas helenísticas ${ }^{329}$ - era a conservação de todos os livros que existissem no mundo (ideal, diga-se de passagem, compartilhado por outras personalidades e instituições ao longo da história). No entanto, havia um critério segundo o qual os livros ao entrarem para tal acervo deveriam ser catalogados e sistematizados por autor, obra e conteúdo; ademais, "essa universalidade e racionalidade dependiam diretamente da fixação escrita dos textos que podiam ser avaliados criticamente, recopiados, encerrados em um livro, classificados e dispostos junto com outros livros ${ }^{330}$ ".

Toda essa mudança de perspectiva causada pela valorização da cultura escrita em detrimento da cultura oral, bem como pelo advento da literatura, causou grande influência nos caminhos da editoração, que já vinha se especializando - frente às demandas de um mercado leitor em desenvolvimento em profissões estritamente vinculadas à produção de livros: o copista (bibliográphos), o especialista em pintar letras capitais (kalligráphos), e o livreiro (biliopóles) ${ }^{331}$. Surgem também, com a divulgação dos textos, as primeiras bibliotecas particulares.

Acontece que, subjacente a quaisquer registros ou expressões, escritas ou imagéticas, sempre existiu algum suporte material que os trouxesse da esfera do invisível para o visível. Outrossim, a evolução do livro teve, do mesmo modo que a escrita e a literatura, sua arte e apogeu, e, direta ou indiretamente, serviu de campo e fomento para várias categorias artísticas que vieram a se constituir ou se desenvolver - tais como a pintura, a gravura e a arte da caligrafia -, e que, junto com o livro e/ou por meio dele, conquistaram sua autonomia.

\footnotetext{
327 Idem.

328 Ibid. (p 14)

330 Idem.

331 ARAÚJO, op. cit. (pp 38-39)
} 
Como vimos, desde os tempos imemoriais e suas origens misteriosas, até os dias de hoje, utilizou-se para esse fim todo o tipo de matéria-prima que se possa imaginar, oriundas, como descreve Martins ${ }^{332}$, dos três reinos da natureza. Do reino mineral - a pedra, o mármore, a argila (que esculpida e cozida iria constituir as famosas tabuletas do acervo das bibliotecas da Mesopotâmia), os metais (desde o chumbo, passando pelo bronze, ouro e prata). Do reino vegetal, destaca-se inicialmente a madeira (que como espécie já se apresentava "pronta" e foi a primeira a ser utilizada, e continua sendo até hoje através do processamento do papel), folhas de palmeiras, papiros, oliveiras, panos (dentre os quais destacase a seda, que, através dos chineses, foi o material que serviu para a invenção do papel). Do reino animal - marfim, osso, cascos de tartaruga, e a pele curtida com a qual se produzia o pergaminho; inclusive, embora haja controvérsias, não só pele animal, mas também a pele humana ${ }^{333}$.

Hoje, com o advento do e-book, a tecnologia oferece-nos suporte "imaterial”, no sentido de impalpável, visto que nessa modalidade tais conteúdos são processados em bits e potencialmente podem ser armazenados na "nuvem"; no entanto, para que se tornem acessíveis à leitura, demandam aparelhos eletrônicos coadjuvantes (e materiais!) que possam portar, acessar e decodificar tais arquivos.

Podemos dizer, então, que a forma que o livro veio adquirindo a partir do uso de tais materiais é originária, a priori, da necessidade de registrar e apreender conteúdos - ideias, histórias, memórias, conhecimento, sentimentos etc. - de natureza imaterial, de maneira que se tornassem acessíveis, duradouros, portáteis e reproduzíveis. Por conseguinte, sua maior ou menor disponibilidade, e valor

332 MARTINS, op. cit. (1957, p 55)

333 Ibid. (pp 55-61). Quanto ao suposto uso de pele humana, segundo Martins há controvérsias entre diversos autores, dentre os quais ele destaca - Rouveyere, Albert Cim, Marcellin Pellet, Lecoy de La Marche -, que por sua vez argumentam desde que "as obras encadernadas em pele humana não são muito raras e existiram realmente, embora já se tenha negado"; "Ao que parece no período do terror na Revolução Francesa, curtiram-se muitas peles humanas e para os mais diversos fins", até que "a pele humana não é bela em encadernação; é muito difícil, senão impossível desengordurá-la completamente". Entretanto, há diversos livros citados como tendo sido encadernados em pele humana, o que nos leva a crer, que não se trate de pura lenda. Fato é que para fazer um único manuscrito eram necessárias dezenas e em alguns casos centenas de peles. O livro citado por Albert Cim e Rouveyere apud Martins, que queremos destacar como exemplo, é o Tratado de Anatomia que o Dr. Antonio Askew (1722-1775) teria encadernado com esse material, "a fim, sem dúvida, de que o exterior da obra correspondesse ao interior". 
cultural e artístico agregado, também variaram de acordo com o valor intrínseco, a demanda, a raridade e a nobreza dos materiais utilizados para salvaguardar tais conteúdos.

Acontece que nesse processo de coisificar ${ }^{334}$ houve um desenvolvimento não só técnico, mas também artístico, que podemos considerar engendrado por duas razões: pela natureza intrínseca da relação do homem com as coisas que pode tocar, sentir, produzir e embelezar esteticamente, isto é, motivado tão somente pelo seu juízo de gosto; e pelo valor atribuído ao conteúdo imaterial que tal coisa tem o poder de salvaguardar, vindo a ser por esse motivo elaborada com materiais nobres e preciosos com o propósito de que possam, de alguma forma, representar tal valor e apreço. Assim sucedeu, por exemplo, com o Livro das Horas, considerado por François Avril ${ }^{335}$, o best-seller da Idade Média, no qual o valor intrínseco e cultural da obra e a forma artística que a envolve transcendem a necessidade stricta de materialização.

À vista disso, na categoria livro há espécies que circulam em outra hierarquia - a de obra de arte. Em um primeiro momento, são eles os livros raros, preciosos ou únicos, qualificados no sentido lato, como obra rara ou livro raro.

\footnotetext{
${ }^{334}$ No sentido de estruturar, formar, materializar.

335 FAILLACE, Vera Lúcia Miranda. Catálogo dos Livros de Horas da Biblioteca Nacional. In "O acervo de livros de horas iluminados da Biblioteca Nacional do Brasil” por François Avril. Rio de Janeiro: FBN (Fundação Biblioteca Nacional), 2016. (p 13). François Avril é historiador, paleógrafo e bibliotecário no Centre de Recherche sur les Manuscrits Enluminés, da Biblioteca Nacional da França. Curador-geral honorário da BnF.
} 


\title{
2.4. O livro raro como obra de arte - fundamentos e conceitos
}

\begin{abstract}
A obra rara, por conceituação, vale mais do que um livro comum e pode ser considerada uma obra de arte por ser uma manifestação artística manufaturada representativa de determinado período histórico. O livro é um objeto complexo que existe enquanto fonte de conhecimento (...) possui uma carga histórica representativa do progresso intelectual e técnico do homem (...) e é a forma que lhe confere beleza expressa em diferentes estilos (...) pelas características de objeto manufaturado ou pelos materiais antigos que resistiram ao tempo $^{336}$.
\end{abstract}

Antes de pensarmos o livro raro como obra de arte, é necessário circunscrever o conceito de raro. No dicionário da língua portuguesa Aurélio, raro significa aquilo "de que há pouco; que não abunda; que é pouco frequente; incomum, invulgar, extraordinário". O conceito aplicado à categoria livro, segundo as autoras do Dicionário do Livro $^{337}$, Maria Isabel Faria e Maria da Graça Pericão, pode ser apresentado, em linhas gerais, como o livro que seja "detentor de alguma particularidade especial (conteúdo, papel, ilustrações) ou por já serem conhecidos poucos exemplares".

Ana Virgínia Pinheiro, chefe do departamento de obras raras da Biblioteca Nacional (2018), face à dificuldade de uma avaliação crítica adequada entre os próprios responsáveis em catalogar obras raras, publicou, em 1986, Que É Livro Raro ${ }^{338}$ contemplado pela $\mathrm{BN}$ com o prêmio Biblioteconomia e Documentação. A obra, fruto de seu estudo e experiência no campo, é a principal

\footnotetext{
336 ROCHA, Christiana Arruda Lee. "O livro como obra-de-arte: critérios teóricos para conservação de obras raras". 2008. (p 32) Monografia apresentada à Universidade Estácio de Sá como trabalho final do curso de Pós-Graduação em Gestão e Conservação de Bens Culturais, selecionado pelo "Programa Nacional de Apoio à Pesquisa".

337 FARIA, Maria Isabel, e PERICÃO, Maria das Graças. Dicionário do Livro. São Paulo: Almedina, 2001. (p 209)

338 PINHEIRO, Ana V. T. da Paz. Que É Livro Raro? Uma metodologia para o estabelecimento de critérios de raridade bibliográfica. Rio de Janeiro: Presença, 1989. Este livro foi contemplado pela Biblioteca Nacional com o prêmio Biblioteconomia e Documentação, em 1986. A autora ainda hoje (2018) exerce a chefia do departamento de obras raras da Biblioteca Nacional.
} 
referência bibliográfica do assunto no Brasil e propõe critérios norteadores aceitos universalmente para distinguir o que vem a ser livro raro, segundo a autora:

O objetivo desse estudo é oferecer critérios para o enfoque de raridade/preciosidade bibliográfica, não universais, mas aceitos universalmente, e associar ao caráter de unicidade atribuído ao livro características tais como: beleza tipográfica, edições limitadas numeradas ou personalizadas; limite histórico, definido pelas características artesanais; autores, editores, impressores, tipógrafos e livreiros célebres; ineditismo do assunto, à luz da época que foi abordado; carência de novas edições de obras muito procuradas; importância histórica de edições comemorativas ou contemporâneas de acontecimentos de inegável relevância histórica; e outros ${ }^{339}$.

A autora, todavia, sublinha antes de especificar tais critérios, que seu estudo não é, de forma alguma, um manual, pois há a necessidade de uma sistematização flexível, visto que, em cada um dos conceitos circunscritos em torno da ideia do que seja obra rara, há uma multiplicidade de enfoques, e delimitá-los sem considerar sua amplitude seria simplificar por demais o problema. Outro ponto para o qual ela nos chama a atenção é o equívoco generalizado pelo senso comum, inclusive entre bibliotecários, de que livro raro é sinônimo de velho e antigo; do mesmo modo, a antiguidade de uma obra não caracteriza sua raridade, assim como uma publicação contemporânea pode apresentar atributos que a qualificam como obra rara.

Após tais considerações iniciais, Pinheiro ${ }^{340}$ aponta para a necessidade de diferenciação, em linhas gerais, dos conceitos raro, precioso e único, circunscritos à ideia de raridade na categoria livro. Segundo ela, o conceito de raro é reconhecido pelo senso comum, em qualquer lugar, pela dificuldade de ser encontrado; o conceito de único refere-se obviamente ao exemplar hipoteticamente único, conhecido ou documentado, pois nunca se sabe de fato se tal exemplar é realmente o único existente (fazemos aqui a ressalva ao livro-único, comum, por exemplo, na categoria livro de artista, em que muitas vezes o exemplar produzido é único na perfeita acepção do termo); e, finalmente, o conceito de precioso, que designa algo a que se atribui grande valor e estima, e

\footnotetext{
339 Ibid. (1986 pp 21)

340 Idem
} 
por isso mesmo possui caráter mais pessoal, considerando-se que, assim como os valores pessoais mudam de pessoa para pessoa, o que é precioso para uma pessoa pode não o ser para outra.

A fim de identificar a obra que seja rara, preciosa e/ou única, deve-se considerar, segundo Pinheiro, os seguintes tópicos: limite histórico, aspectos bibliográficos, valor cultural, pesquisa bibliográfica e características do exemplar. Cada um desses critérios contempla aspectos específicos da obra e do contexto histórico no qual ela está inserida. Considerando tal sistematização norteadora para o campo em questão, transcrevemos resumidamente cada um desses itens.

1. Limite histórico. Essa abordagem é definida pela datação, isto é, são considerados obras raras todos os livros manuscritos até a invenção da imprensa no século XV. Compreende ainda os chamados incunábulos - primeiros livros impressos no início da história da imprensa -, assim como todo o período caracterizado pela produção artesanal dos impressos, que finda com o advento da produção industrial dos livros, por volta de $1801^{341}$.

2. Aspectos bibliográficos. O advento da produção industrial dos livros não extinguiu por completo volumes produzidos artesanalmente; tal processo subsiste ainda hoje nas casas editoriais artesanais, em eventuais publicações de escritores independentes, designers, artistas gráficos e artistas que se dedicam ao campo do livro de artista. Independentemente de sua datação, tais aspectos são contemplados nas obras com beleza tipográfica e graficamente artísticas. Dentre as principais características, Pinheiro ressalta a natureza dos materiais utilizados como suporte para impressão, tais quais papel de linho, pergaminho, tintas, encadernações originais luxuosas, edições de luxo etc., e as ilustrações criadas com técnicas artesanais, tais como água-forte, aquarela, xilogravura, entre outras $^{342}$.

3. O valor cultural da obra. Embora esse aspecto tenha ampla abrangência, pode ser analisado a partir das seguintes perspectivas: a) edições limitadas e esgotadas, especiais e fac-similares, personalizadas e numeradas,

\footnotetext{
341 Ibid. (1986 pp 22-35)

342 Idem.
} 
críticas, definitivas e diplomáticas; b) os assuntos tratados à luz da época em que foram pensados e escritos, tais como obras científicas que datam do período de ascensão daquela ciência; histórias de descobrimentos e colonizações; teses; obras impressas em circunstâncias pouco convenientes a essa arte, como guerra, seca, fome etc.; memórias históricas de famílias nobres, usos e costumes; edições censuradas, interditadas e expurgadas; obras "desaparecidas" face às contingências do tempo e da sorte; edições contrafeitas e emissões; primitivas e originais; edições populares, especialmente romances e folhetos literários; panfletos, papéis impressos, folhas volantes etc.; c) edições de artífices renomados e/ou considerados na história das artes que representam, tais como tipógrafos, impressores, editores, desenhistas, pintores, gravadores etc.; d) edições de clássicos assim considerados nas histórias das literaturas especificas.

4. Pesquisa bibliográfica. Através dessas fontes encontram-se as indicações das seguintes características da obra em si ou do exemplar: a) unicidade e raridade, sob o ponto de vista de bibliógrafos, bibliófilos e de especialistas de assunto da obra - há que se considerar aqui, apenas a classificação de uma obra/exemplar com o epíteto de única, como rara, e não como a de "única conhecida"; essa característica deve estar bem fundamentada em bibliografias de mérito reconhecido; b) preciosidade e celebridade, referindo-se àquelas obras mais procuradas por bibliófilos - por quaisquer razões - e/ou mais estudadas por eruditos; c) curiosidade, referindo-se àquelas obras em que o assunto foi tratado de maneira sui generis ou de apresentação tipográfica incomum; d) fontes de informações comerciais que vão avaliar, em espécie, cada unidade bibliográfica, isto é, o preço passa a ser o indicador de "raridade" 343.

5. Características do exemplar. Essa abordagem avalia os elementos acrescentados a unidades bibliográficas em período posterior à publicação, tais como: a) marcas de propriedade denominadas super-libris ou ex-libris ${ }^{344}$, assinaturas, indicando que aquele exemplar pertenceu a um conjunto bibliográfico

\footnotetext{
343 Idem.

${ }^{344}$ Idem. Marca ou vinheta que designa a propriedade de um livro, denominada super-libris quando gravada na encadernação da obra, e ex-libris quando localizada geralmente no verso da capa do livro.
} 
de personalidade famosa e/ou importante, marcas de fogo ${ }^{345}$; b) marcas de artificies/comerciantes renomados e/ou considerados no mercado livresco, tais quais encadernadores, restauradores, livreiros etc.; c) dedicatórias de personalidades famosas ou importantes ${ }^{346}$.

Analisando os preceitos apresentados, distinguimos que os itens 2, 3 e 4 são pertinentes ao valor intrínseco da obra, isto é, à unicidade, raridade e preciosidade relacionados ao que tange a coisa livro em seus aspectos formais e materiais, bem como ao valor cultural ou científico de seu conteúdo. Os demais itens, 1 e 5, são fatores extrínsecos, que agregam valor à obra a posteriori - de sua criação, publicação e circulação -, pois estão relacionados à datação e ao percurso histórico, que combinados entre si contam-nos o destino de tal livro no mundo através de suas marcas e repercussão alcançada.

Sobre esse aspecto, De Hamel $^{347}$ traz-nos a ideia de que cada livro tem uma "biografia" por meio da qual nos contam histórias marcadas pela sua passagem entre nós. De acordo com esse pressuposto, não só a obra em si, como cada exemplar terá, necessariamente, seu próprio destino.

\begin{abstract}
Manuscritos medievais têm biografias. Eles têm sobrevivido através de séculos (...) até nossa época. Às vezes essas histórias são muito dramáticas, quando livros assumem seu lugar nas questões da Europa em seu mais alto nível, desde as alcovas de santos e reis medievais aos lugares secretos de esconderijo na Alemanha nazista. Habent su fata libelli (Os livros têm seu destino). Alguns manuscritos mal saíram de suas prateleiras originais desde o dia em que foram completados; outros há que ziguezaguearam pelo mundo conhecido em baús de madeira ou alforjes que oscilavam no dorso dos cavalos, ou através dos oceanos em pequenos veleiros, ou como carga aérea, pois livros são muito portáteis. Muitos, em algum momento, passaram pelo comércio ou por salas de leilão, e os preços a eles atribuídos enquanto assim transitavam é parte de uma história mutante de gosto e de moda. A vida de cada manuscrito, como a de cada pessoa, é diferente, e todos têm histórias a contar ${ }^{348}$.
\end{abstract}

Dentre os fatores extrínsecos que podem distinguir um livro como obra rara, além do critério de datação, estão justamente os rastros e marcas desse destino, visto

\footnotetext{
${ }^{345}$ Idem.

${ }^{346}$ Idem.

${ }^{347}$ DE HAMEL, op. cit. (p 10)

${ }^{348}$ Idem.
} 
que podem ter sido admirados, ocultos, negligenciados, desejados, queimados, perseguidos, censurados etc., o que termina por lhes conferir uma "biografia" através da qual surgem dedicatórias, registros, anotações, comentários e outras insígnias.

Por fim, Pinheiro ${ }^{349}$ considera que para alcançar o status de raridade, a obra deve atender a pelo menos um dos requisitos elencados, considerando que algumas obras atendem a vários requisitos ao mesmo tempo. Todavia, ela aponta como fator preponderante na determinação de raridade da obra a sua importância intrínseca, isto é, o quão importante o livro é considerado na sua área. 


\title{
2.5 O livro raro, precioso e único - obra de arte e patrimônio cultural
}

\begin{abstract}
Os livros raros, assim classificados por suas características intrínsecas, possuem qualidades que necessitam de especial atenção, principalmente no que diz respeito à sua conservação. Portanto, podem ser considerados patrimônio cultural e, como tal, devem se submeter às políticas de preservação, assim como outras manifestações artísticas. (...) Assim, no que diz respeito à conservação do livro raro, sua estrutura deve ser respeitada enquanto obra de arte e patrimônio artístico-cultural, assim como quadros, esculturas e monumentos arquitetônicos ${ }^{350}$.
\end{abstract}

Além da fundamentação apresentada para circunscrever os livros que circulam na categoria de obra de arte, há outro fator subjacente a sua natureza que os legitima como tal: o livro enquanto objeto apresenta fragilidade, pois os materiais que sustentam a obra são suscetíveis à ação do tempo; portanto, as obras consideradas raras são contempladas pelas políticas públicas de preservação de patrimônio cultural, com isso passando a figurar, independentemente de sua aparência ou estilo, na categoria de obra de arte ${ }^{351}$.

Devemos salientar, inclusive, que a fragilidade dos materiais que os constituem, sejam eles quais forem dentre a diversidade possível, torna-os muito mais suscetíveis à ação do tempo do que quadros, esculturas e monumentos arquitetônicos. Tal consideração faz-se relevante, visto que essa mesma fragilidade imposta naturalmente pela natureza constituinte dos materiais que os circunscrevem às políticas de preservação e os legitima como patrimônio cultural contribui involuntariamente para que a arte do livro seja vista como uma arte menor, devido ao paradigma cultural imposto em torno da questão: cópia $\mathrm{x}$ originalidade. De fato, uma pintura, por exemplo, é única, enquanto livros são cópias de um original. Um quadro de Picasso, por sua vez, vale mais do que uma gravura do próprio artista, em função da reprodução permitida - embora limitada a um número de tiragem específico - dentro da categoria. Entretanto, devemos considerar que, assim como a reprodução de uma gravura é pertinente à categoria,

ROCHA, op. cit. (2008, pp 46-47)

Idem. 
do mesmo modo, a reprodução de cópias de livros para circulação em vez de seus originais é inerente à natureza do campo do livro, portanto, consideramos que esse quesito não deveria contribuir para a desvalia da arte do livro. Ademais, deve-se atentar para as diversas perspectivas históricas, que mudam com o tempo, e, por conseguinte, também seus valores.

No mundo moderno, o simples ato de copiar encerra um conceito pejorativo, sobretudo quando aplicado à literatura e à arte. Escritores e artistas hoje em dia empenham-se, em vez disso, em sua originalidade e inventividade. O plágio é um anátema. Na Europa Medieval, no entanto, a cópia era objeto de admiração. Artistas eram treinados em imitar as obras uns dos outros. Modelos e fórmulas herdados de outrem eram devidamente repetidos sem referência à realidade. A autoridade (auctoritas) era sempre respeitada e invocada. Autores recorriam a escritores anteriores, com frequência ocultando a efetiva originalidade numa pretensão de que tudo já fora dito antes. Até mesmo em ficção criativa, autores como Boccaccio e Chaucer, começavam suas histórias alegando ter descoberto suas narrativas em livros antigos ${ }^{352}$.

Outra questão da maior importância que contribui involuntariamente para o reconhecimento limitado que se tem para com a arte do livro, e do livro como obra de arte, são as poucas exposições específicas de livros raros ou livros de artistas - que, inclusive, muitas vezes são expostos apenas como objetos coadjuvantes de alguma exposição mais abrangente, e, quando expostos, via de regra, só podem ser vistos parcialmente, à distância e protegidos em seus expositores de vidro. $\mathrm{O}$ acesso restrito que se tem a tais livros, seja através de uma exposição ou pela (im)provável visita ao acervo de uma biblioteca pública, justifica-se justamente por sua fragilidade e preciosidade.

Acreditamos serem fundamentais tais ponderações, não só para o pleno entendimento dos preceitos que dão legitimidade ao livro como obra de arte, como também para a compreensão das especificidades e paradigmas da categoria livro, nos âmbitos da história do livro e da história da arte.

\footnotetext{
${ }^{352}$ DE HAMEL, op. cit. ( $p$ 10)
} 


\subsection{Livros raros e livros de artistas - especificidades e aproximações}

O diálogo entre livros de artista contemporâneos e livros considerados raros remete à gênese do livro e da escrita e às relações entre palavras e imagens ${ }^{353}$.

Dentre as espécies de livros que circulam na categoria de obra de arte, além dos livros raros, assim qualificados de acordo com os critérios apresentados, há os livres de peintre, livres d'art e os livres d'artiste. Entretanto, diferentemente do livro raro que conquista o status de obra arte, a posteriori, esses modelos já nascem com tal status, visto que são produtos, a priori, de uma categoria artística que tem como objeto e campo o livro. Portanto, conforme descreve Veneroso ${ }^{354}$, "em geral, o estudo de livros de artista e de livros considerados raros dá-se separadamente", dado que a qualificação de um livro de artista como tal se dá a partir de especificidades pertinentes ao campo da arte. Veneroso, todavia ${ }^{355}$, aponta para as aproximações entre livros raros e livros de artista, que terminam, em geral, por circunscrever o livro de artista também como livro raro. Mesmo reconhecendo tratar-se de tema controverso, ela ressalta as aproximações, diálogos e afinidades entre essas duas espécies, que terminam por justificar que livros de artista recebam o tratamento dispensado às obras raras/especiais, pois de fato é o que eles frequentemente se tornam ${ }^{356}$.

É interessante notar que livros de artista têm se tornado, com frequência, livros raros. Assim, o Setor de Obras Especiais da Biblioteca pode ser considerado um lugar adequado para a guarda e a exibição de livros de artista, já que ali eles se encontram em diálogo com livros especiais e raros, como incunábulos $\mathrm{e}$ livres de peintres, dos quais eles se $\operatorname{aproximam}^{357}$.

\footnotetext{
353 VENEROSO, Maria do Carmo de Freitas. "Livros de artista e livros raros: aproximações" in Perspectivas em Ciência da Informação, v.22, número especial, p 186, jul. 2017. Maria do Carmo de Freitas Veneroso é Doutora em Estudos Literários pela Universidade Federal de Minas Gerais. Professora titular da Escola de Belas Artes da Universidade Federal de Minas Gerais.

354 Ibid. (2017, p 189)

${ }^{355}$ Idem.

${ }^{356}$ Idem.

${ }^{357}$ Idem.
} 
Ademais, a pertença compartilhada entre as mesmas categorias - livro e obra de arte - naturalmente os coloca em diálogo. Tal diálogo - entre livros raros e livros de artista - "remete à gênese do livro e da escrita e às relações entre palavras e imagens ${ }^{358, ", ~ p o i s, ~ e m ~ g e r a l, ~ n e s s a s ~ e s p e ́ c i e s, ~ e m ~ v e z ~ d e ~ s e ~ d a r ~ u m a ~}$ relação hierárquica como costuma ocorrer entre texto e ilustração nos livros comuns, há uma equivalência entre imagem e texto, como era nos nossos primeiros livros.

A escrita e o livro, nas suas formas mais antigas, como as tabuletas da escrita cuneiforme e os rolos de papiro em escritas hieroglíficas, continham um forte caráter icônico, e a palavra podia ser vista também como imagem, como acontece atualmente em muitos livros de artista. (...) o que há é um diálogo palavra-imagem, em que a palavra pode ser considerada também pelas suas qualidades visuais, podendo ser vista como imagem, ao mesmo tempo que a imagem também pode ser lida como um texto 359 .

Levando em conta tais aproximações, sem deixar de preservar suas especificidades, nos próximos capítulos iremos contemplar a gênese e a poética de cada uma dessas espécies.

\footnotetext{
358 Ibid. (p 187)

359 Idem.
} 


\title{
3. OS MANUSCRITOS MEDIEVAIS ILUMINADOS - 0 livro raro que habita o nosso imaginário
}

\begin{abstract}
Movido por necessidades concretas sempre novas, o potencial criador do homem surge na história como um fator de realização e constante transformação. Ele afeta o mundo físico, a própria condição humana e os contextos culturais ${ }^{360}$.
\end{abstract}

Dentre as espécies de livros que transitam na categoria de obra de arte livros raros e livros de artista -, o manuscrito medieval iluminado é, por excelência, o livro raro que habita nosso imaginário. Portanto, sem deixar de levar em consideração a herança na produção manuscrita dos papiros do Egito, nosso percurso histórico começa no medievo devido às referências artísticas de seus manuscritos, e, também, porque é nesse período que o livro tal qual o conhecemos adquire sua forma, estrutura, valor simbólico e cultural. Ademais, a estética formal do $L V$ vai ao encontro de tal modelo.

O livro manuscrito foi, durante muitos séculos, no ocidente, o único instrumento de disseminação do pensamento ${ }^{361}$; entretanto, é preciso, antes de mais nada, diferenciar o modelo que temos em nosso imaginário - o manuscrito medieval iluminado -, de seus antecessores, os também manuscritos rolos de papiro ou ainda as tabuletas de argila mesopotâmicas, pois, no sentido stricto, manuscrito designa tudo o que foi escrito a mão - manus, do latim, mão; e scriptus, do latim escrever. Contudo, são os livros feitos dessa maneira - escritos a mão na Idade Média - que ficaram mais conhecidos como manuscritos. ${ }^{362}$ Fato é que, antes da invenção da tipografia, tudo se copiava a mão; o que pouco se sabe é que depois da invenção da imprensa, até meados do século XIX, embora a produção de manuscritos tenha se tornado cada vez mais restrita, ainda subsistia de alguma forma. Martins (957) faz uma descrição detalhada a fim de esclarecer o uso correto do termo, inclusive, suas convenções contemporâneas: A rigor, manuscrito é o texto escrito a mão, seja qual for o instrumento auxiliar, seja qual for a matéria que o receba. (...) Nessas condições, seriam

\footnotetext{
360 OSTROWER, F. Criatividade e Processos de Criação. Petrópolis: Vozes, 1997. (p 10)

361 FEBVRE e MARTIN, Lucien, Henri-Jean. O Aparecimento do Livro. São Paulo: Edusp, 2017. (p 11)

362 VISALLI, GODOI, Angelita Marques e Wanessa. “Estudos sobre imagens medievais: o caso das iluminuras". (2016, p 8) Disponível em http://dx.doi.org/10.4025/dialogos.v20i3.33666 acesso em 26/11/2018 às 20:30 Doutora em História Social pela USP e Professora da área de História Medieval do departamento de História da UEL, e, Pamela Wanessa Godoi, Doutoranda em História Social pela USP. (WALTHER; WOLF, apud VISALLI; GODOI, p 8, 2016).
} 
manuscritos todas as "inscrições" feitas em papel ou em pedra, marfim, bronze ou mármore. Mas, uma convenção por todos admitida reserva esse nome aos "manuscritos" em papel, papiro ou pergaminho, e aos demais o nome de gravura ou de escultura. Assim, a palavra "manuscrito" evoca sem dubiedade a ideia da folha de papel, de papiro ou de pergaminho, escrita a mão, e até, visto que nem sempre são sincrônicos os progressos técnicos e os progressos vocabulares, a folha de papel datilografada, quando ela representa o "original" vindo das mãos do escritor. É assim que muitos escritores entregam à tipografia o seu... "manuscrito", isto é, a cópia datilografada de um texto que, com frequência cada vez maior, já foi inicialmente escrito também a máquina (ou digitado em computador $)^{363}$.

Portanto, "manuscrito" é o texto escrito a mão em papiro, pergaminho ou papel, e o manuscrito medieval será, por consequência, um texto nessas condições, datado da Idade Média ${ }^{364}$. Acontece que o modelo que se desenvolveu gradualmente no medievo, entre os séculos I e XV de nossa era, é justamente o precursor direto do livro tal qual o concebemos hoje - folhas agrupadas entre capas mais resistentes -, ou seja, apesar do reconhecimento das tabuletas de argila mesopotâmicas e dos rolos de papiro como precursores do livro, o manuscrito medieval é nossa referência mais familiar, visto que sua morfologia desde então continua a mesma. Conhecido como códice - "palavra medieval que nomeava o tronco da árvore e era usada para designar o produto final de uma junção de páginas, as quais, como as folhas de uma árvore, uniam-se a uma placa que servia de apoio lateral para serem costuradas ${ }^{365 "}$ ", é em suma "o livro quadrado e chato, tal como ainda hoje o possuímos"366.

O aparecimento do livro "moderno" ocorreu entre os últimos séculos da Antiguidade e os primeiros da Idade Média (IV a.C. - IV d.C.). Para Araújo ${ }^{367}$, os créditos da invenção do códice, que significou a mudança mais radical e fundamental na história do livro - substituindo rapidamente o rolo de papiro que perdurou por cerca de três milênios e sete séculos -, é devido à Antiguidade.

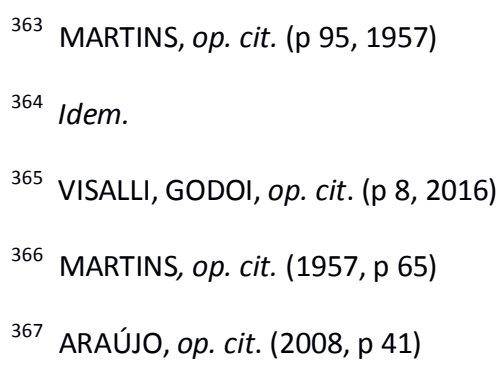


Progressivamente o novo modelo vai se impondo, até que, por fim, a partir do século IV, o livro-rolo de papiro desaparece completamente. A adoção do códice, (...), no século II, por exemplo, acha-se representada na literatura pagã do Egito com apenas $2,31 \%$, no século III com $16,8 \%$, mas já no século IV tal proporção ascende a nada menos de 73,95\%, sem contar a Bíblia, cujos fragmentos, mesmo os mais antigos, aparecem quase sempre sob esse feitio ${ }^{368}$.

Para Cavallo ${ }^{369}$, o códice é uma invenção romana. Ele descreve como, a partir do século II d.C., o livro em forma de rolo proveniente do mundo helenístico declina até o total domínio do códice, o que se constata, no mundo grego, por volta do início do século V. Segundo ele, os últimos livros latinos em forma de rolo que sobreviveram devem datar de entre o final do século III e início do século IV, entretanto, embora haja testemunho escasso que comprove tal hipótese, no Ocidente Romano o fenômeno acontece em data anterior. Ele ressalta que o poeta Marcial, já no final do século I, “fala dos códices de conteúdo literário - Homero, Virgílio, Cícero, Lívio, Ovídio, além de seus próprios epigramas como sendo livros produzidos por oficinas livreiras, portanto com um certo número de exemplares" ${ }^{, 370}$. Aponta ainda o fragmento do códice latino, De bellis Macedonicis, datado do século I ou II, como um dos mais antigos códices conservados; em suma, ele conclui: "Tudo isso faz crer que no Ocidente Romano a definitiva afirmação do códice deve datar do final do século III, portanto, bem antes de seu aparecimento na parte grega do Império"371 . A convicção de Cavallo fundamenta-se em outras tantas deduções, no entanto, como ele mesmo reconhece, há controvérsias. Eis seus argumentos:

(...) muito mais rapidamente, os cristãos tanto no Ocidente quanto no Oriente adotaram o códice. E de tal forma que os livros de seu credo são, desde o início, quase todos desse tipo. Mas não é preciso muito para deduzir que foram os cristãos que o inventaram: sob a forma primitiva de tabuinhas, cadernos e cadernetas, o códice já era, desde tempos antiquíssimos,

\footnotetext{
${ }^{368}$ Idem.

${ }^{369}$ CAVALLO, CHARTIER, Guglielmo e Roger. Op. cit. História da Leitura no Mundo Ocidental, in "Entre volumen e códex, a leitura no mundo romano". São Paulo: Ática, 1998. (p.91); in "Entre volumen e códex, a leitura no mundo romano".

370 Idem.

371 Idem.
} 
conhecido no mundo romano. Além disso, em suas origens, o cristianismo foi uma religião baseada na palavra, na pregação, na "viva-voz" que, na tradição greco-romana, estava na base da retórica e do ensino escolar ou técnico, mesmo que o livro pudesse exercer uma função de guia complementar. Todavia, quando o cristianismo confrontou-se com uma sociedade em que inúmeros indivíduos tinham acesso à cultura escrita, e compreendeu que é preciso recorrer ao livro para a difusão de sua mensagem, escolheu decisivamente o códice ${ }^{372}$.

Fischer $^{373}$, aponta o século IV d.C. como o período em que o códice em velino realmente substituiu os rolos em papiro e começam a ser chamados em inglês de books - do alemão bõkã, ou "beech" ("faia"), referência ao antigo material de que eram feitas as tabuletas em runas -, vindo a ser, segundo ele, a forma literária preferida na Europa. Fischer também cita os seis epigramas do poeta Marcial (40103 d.C.) nos códices que continham as obras de Homero, Virgílio, Cícero, Lívio, Ovídio e do próprio Marcial. Para ele, esses seriam os primeiros livros "modernos ${ }^{374 ", ~ C a v a l l o ~}{ }^{375}$ concorda com Fischer e circunscreve outros fatores determinantes para tal apropriação: a) O rolo estava ligado à tradição cultural das classes dominantes, portanto, o códice afirmava sua diferença; b) O cristianismo, ao se propor como revelação escrita destinada a todos, dirigia-se a todo indivíduo alfabetizado, independentemente do nível sociocultural, e não apenas ao público tradicional habituado ao livro-rolo; portanto, a forma do códice era mais adequada, visto que era como cadernetas de anotação ou cadernos de aula, mais acessíveis a esse público, inclusive economicamente; c) As possibilidades de organização - anotação, referências, divisão de seções e localização de trechos -, que a paginação oferecia, agregavam um grande diferencial, e tornaram-se facilitadoras para sua assimilação.

Diante da imprecisão de sua datação e, por conseguinte, dos devidos créditos ao desenvolvimento do códice, só é possível tecer conjecturas, de modo que, conquanto os avanços e as demandas ocorridas na Antiguidade tenham certamente engendrado esse novo design, sua consolidação deu-se entre os cristãos, visto que, além do cristianismo constituir-se como uma religião

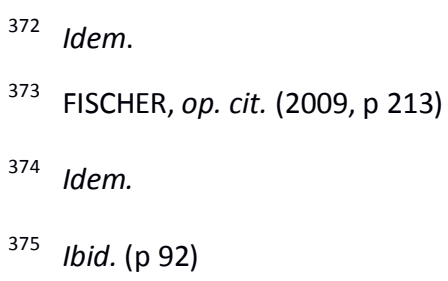


fundamentada na palavra escrita, qual seja, no livro sagrado; toda a herança, manutenção e reprodução dos textos clássicos da Antiguidade ficaram, durante o medievo, principalmente sob a posse e guarda de seus monges. Segundo Emanuel Araújo, "aceita-se pacificamente que, no Ocidente, o maior impulso de estudos e recuperação de textos deveu-se, até o século XV, à iniciativa dos monges”, pois, embora houvesse antes intensa atividade de editoração, foi "sobretudo nos conventos e abadias, que se buscou com afinco não só a conservação dos textos clássicos através de cópias, como, ainda, pretendeu-se reagrupar em grandes enciclopédias e compêndios todo o conhecimento adquirido"376. Isso posto, o que realmente importa é que os cristãos assenhoraram-se do novo modelo, e, certamente, a relação estabelecida com tal objeto foi determinante para apogeu da arte de tais manuscritos.

Ademais, houve a mudança do gesto e da ambiência para a leitura provocada por esse novo formato. Ressaltamos aqui a atenção que devemos dar a tais relações naturalmente intrínsecas, de modo que, embora a história da escrita, da leitura e a do livro tenham suas especificidades, são na verdade interdependentes, o que nos solicita, sempre, um olhar abrangente.

É preciso considerar que as formas produzem sentido e que um texto reveste-se de uma significação e de um estatuto inéditos quando mudam os suportes que o propõem à leitura. Toda história das práticas da leitura é, portanto, necessariamente uma história dos objetos escritos e das palavras leitoras. É preciso observar, também, que a leitura é sempre uma prática encarnada por gestos, espaços e hábitos ${ }^{377}$.

A grande revolução do livro ${ }^{378}$ deu-se justamente nessa nova relação gestual instaurada nas práticas de leitura e escrita, desde o advento do códice, vindo literalmente a liberar o gesto imposto pelo antigo modelo.Para ser desenrolado e lido, um rolo tinha que ser segurado com as duas mãos: logo, como o mostram os afrescos e baixos-relevos, era impossível para o leitor escrever ao mesmo tempo que lia, daí a importância do ditado em voz alta. É com o codex que o leitor

\footnotetext{
376 ARAÚJO, op. cit. (2008, pp 42-43)

377 CAVALLO, CHARTIER, op. cit. (1998, p 6)

378 Tal informação é unânime entre todos os autores da bibliografia consultada.
} 
conquista a liberdade: pousado sobre uma mesa ou escrivaninhas, o livro em cadernos não exige mais a total mobilização do corpo. Em relação a ele, o leitor pode distanciar-se, ler e escrever ao mesmo tempo, indo, ao seu bel-prazer de uma página à outra ${ }^{379}$.

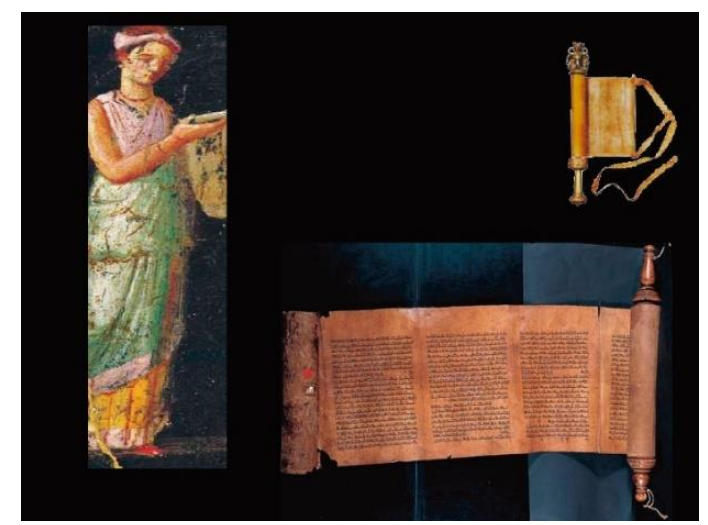

Figura 2521: Leitura com o rolo de papiro "Volumen" Figura 26: Leitura com o códice

“Cum legebat, oculi ducebantur per paginas...” escreveu Santo Agostinho com aparente incredulidade no início dos anos 400 d.C.: “(...) quando ele estava lendo, varria as folhas com os olhos, e seu coração procurava sentido, mas a voz e a língua silenciavam. Com frequência, quando estávamos presentes (...) ainda o vimos lendo para si mesmo, e não de outra maneira (...) Mas com qual intenção ele o fazia, certamente aquele homem tinha uma boa razão". O espanto de Santo Agostinho testemunhando a leitura silenciosa de seu professor Santo Ambrósio, decorria do fato de que as pessoas liam em voz alta. A literatura era principalmente um auxiliar da memória (...) os textos literários eram quase exclusivamente entoados como um canto ou pelo menos murmurados para meditação e melhor memorização ${ }^{380}$.

Aos poucos, por meio do novo gesto, a leitura silenciosa, que na Antiguidade, era vista como algo extraordinário, consolida-se para qualquer texto, sagrado ou profano, no Oriente ou no Ocidente, e para toda e qualquer classe social.

Acontece que, a elaboração de uma arte deslumbrante - a caligrafia -, ornada de maravilhosas iluminuras - do latim, illuminatio, illuminare ou 
illuminator $^{381}$-, valoriza sobremaneira esses nossos primeiros $\operatorname{livros}^{382}$, e justifica o fascínio que temos pelos manuscritos medievais iluminados ${ }^{383}$, pois, era raro um manuscrito que não tivesse nada além da escrita, "Quase todos os manuscritos medievais são decorados de algum modo, no mínimo com iniciais coloridas e não raro com ouro e figuras ${ }^{384,}$. Temos, todavia, que reconhecer que tal arte é devedora da arte egípcia, na qual o diálogo entre a escrita e a linguagem pictórica levava todo artista a aprender também a arte da bela escrita. Para Fischer, a escrita egípcia seria "um dos sistemas de escrita mais belos e cativantes do mundo 385 ", além do que, além de funcionais, eram também decorativos, e já traziam suas escrituras sagradas ilustradas com desenhos altamente estilizados. Gombrich ${ }^{386}$ inclusive, sublinha que, apesar de a arte ter surgido em diferentes regiões do mundo, há uma tradição direta "transmitida de mestre a discípulo, e de discípulo a admirador ou copista, a qual vincula a arte de nosso tempo - cada construção ou cada cartaz - à arte do vale do Nilo de uns cinco mil anos atrás", de maneira que todos somos de alguma forma discípulos dos gregos, que por sua vez, aprenderam com os egípcios ${ }^{387}$.

Ocorre que o papiro, muito utilizado pelos antigos escribas e considerado o mais célebre de todos os produtos vegetais empregados na escrita ${ }^{388}$, apresentava diversos problemas: era caro, frágil, e só uma de suas faces prestava-se à escrita. Sua conservação era difícil, devido à delicadeza e vulnerabilidade de sua matériaprima, e o manuseio de seus rolos facilmente danificava a pintura, que tendia a estalar e soltar-se, de forma que pouco desse material sobreviveu até hoje, quase não havendo, inclusive, dados históricos precisos sobre seu surgimento e desenvolvimento.

\footnotetext{
${ }^{381}$ FAILLACCE, op. cit. (2016, p.21)

382 Idem.

383 DE HAMEL, op. cit. (2017. (p 10)

384 Ibid. (p 12)

385 FISCHER, op. cit. (2009, p 35)

${ }^{386}$ GOMBRICH, op. cit. (p 84)

387 MARTINS, op. cit. (p 96)

${ }^{388}$ Idem.
} 
Nada se sabe do momento em que se transformou o papiro em material de escrita. O Museu do Louvre possui um papiro que data de 237 a.C., escrito em hieróglifos demóticos (ultima transformação da escrita egípcia). Supõe-se que os papiros mais velhos datem de 3.500 a.C. Chartoe era o papiro preparado que podia ser utilizado na escrita. Sobre cada folha, o texto era escrito em colunas, e colava-se cada folha, em seguida, pela extremidade, à folha seguinte, de forma que se obtinham fitas de papiro com, às vezes, $18 \mathrm{~m}$ de comprimento. Enroladas em torno de um bastonete chamado umbilicus, constituíam os primeiros rolos, antepassados dos de pergaminho ${ }^{389}$.

Originário do reino vegetal - Cyperus papyrus -, comum às margens do Nilo, foi o principal suporte da escrita na Antiguidade, e seus registros mais antigos datam de 3000 a.C., no Egito. Inúmeros desses volumens estariam sob a salvaguarda da mais famosa biblioteca egípcia de toda a antiguidade - a biblioteca de Alexandria -, fundada por volta de 290 a. C., mas foram destruídos em incêndios históricos e intencionais, até que por fim, o terceiro incêndio a destruiu completamente. $^{390}$

O pergaminho, suporte que substituiu o papiro, surge da necessidade de se buscar uma nova matéria-prima, a partir de um dado momento no século II a. C., em que o Egito recusou o fornecimento do papiro a Pérgamo, então sua rival. Sua produção era monopolizada pelo Estado do Egito e representava importante fonte de renda, uma vez que desde o terceiro milênio antes de nossa era vinha sendo exportado para toda a bacia do Mediterrâneo. Com a falta de fornecimento, os escribas da Ásia Menor precisaram recorrer a outro material - o couro - originário do reino animal, em geral confeccionado a partir de peles do bezerro, cabra, carneiro/ovelha, entretanto, alguns bibliógrafos afirmam terem existido livros escritos em pergaminhos produzidos com pele humana. A referência mais antiga é de um exemplar grego, datado em II a. C. ${ }^{391}$ Contudo, Martins afirma que o uso de peles como substratum da escrita já era uma prática antiga na Ásia, e "tudo o que se pode ter feito em Pérgamo é melhorar-lhe a preparação ${ }^{392 \%,}$, inclusive, diz

\footnotetext{
${ }^{389}$ Idem.

390 Ibid. (p 97)

391 lbid. (p 98)

392 MARTINS, op. cit. (p 99)
} 
ele, inicialmente usava-se o pergaminho tal qual o papiro, aos poucos é que o potencial do material foi sendo descoberto.

O pergaminho era escrito, como o papiro, de um lado só, até que se descobriu ser perfeitamente possível fazê-lo nas duas faces. Enquanto a escrita era realizada apenas no reto, o pergaminho era enrolado, como o papiro, para constituir o volumem. A escrita no reto e no verso vai dar nascimento ao codex, isto é, ao antepassado imediato do livro. Com ele revoluciona-se $\mathrm{o}$ aspecto da matéria escrita e o das bibliotecas ${ }^{393}$.

Assim, além de substituir o papiro em função da demanda, o pergaminho e a adequação de um novo design que fosse capaz de absorver plenamente seus atributos revelaram-se preponderantes para a evolução do livro, consolidada naquele momento pela mudança do rolo para o códice. Acontece que o surgimento dessa nova superfície proporcionou duas das inovações fundamentais, sem as quais não teria sido possível aprimorar esse gênero de pintura: a capacidade de dobrar e costurar as folhas (que, como vimos anteriormente, originou o códice) e a utilização da pena de ganso com suas infinitas variações e possibilidades, em substituição ao antigo e limitado pincel de caniço. Para Georges Jean, "sem a invenção do pergaminho, a arte sublime da iluminura não teria jamais conhecido tal brilho ${ }^{394,}$, pois a linguagem pictórica refinou-se de tal forma, que adquiriu uma identidade e luz próprias, literalmente iluminando, decorando e embelezando tais livros, constituindo assim, um capítulo à parte na história da arte. Na Idade Média e também hoje, iluminuras são consideradas belas, não apenas por causa de um elaborado design que emoldura sua apresentação e delineia toda a delicadeza das figuras humanas representadas. São belas também por causa do efeito causado pelo uso de materiais nobres em sua feitura: pigmentos coloridos e folhas de ouro que, efetivamente, iluminam ${ }^{395}$.

Os monges copistas, ao contrário dos escribas da Mesopotâmia ou do antigo Egito, não possuíam status nem poder, no entanto, tornaram-se artistas -

\footnotetext{
393 Idem.

394 JEAN, Georges. A Escrita - Memória dos homens. Rio de Janeiro: Objetiva, 2008. (p 80)

395 FAILLACCE. op. cit. (2016, p 21)
} 
calígrafos, iluminadores, miniaturistas e encadernadores -, e seus trabalhos, obras-primas ${ }^{396}$. "Alguns dentre eles produziam verdadeiras maravilhas ${ }^{397 " .}$

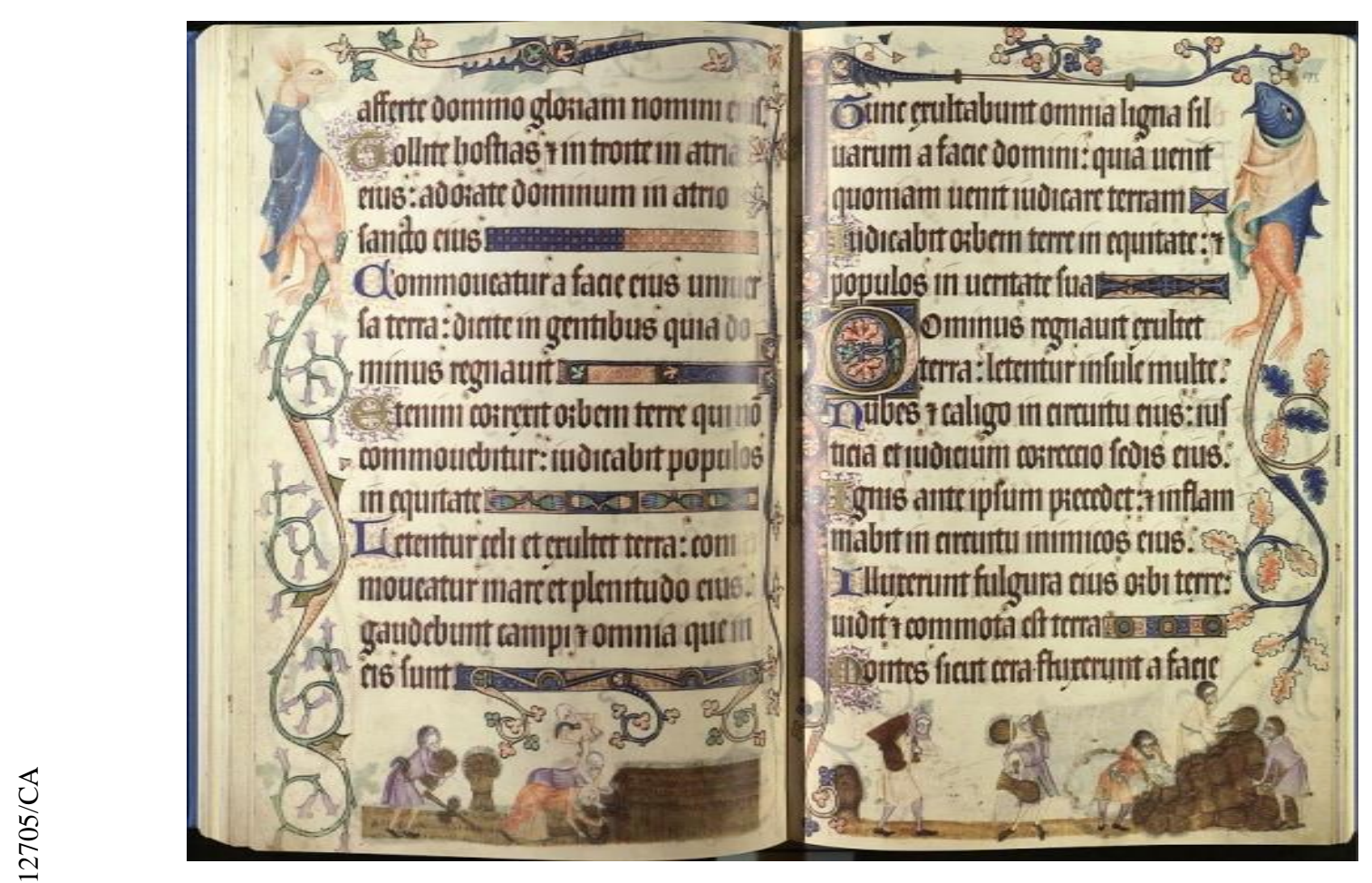

Figura 227: Iluminura

396 JEAN, Georges. op. cit. (p 84)

397 Ibid. (p 91) 


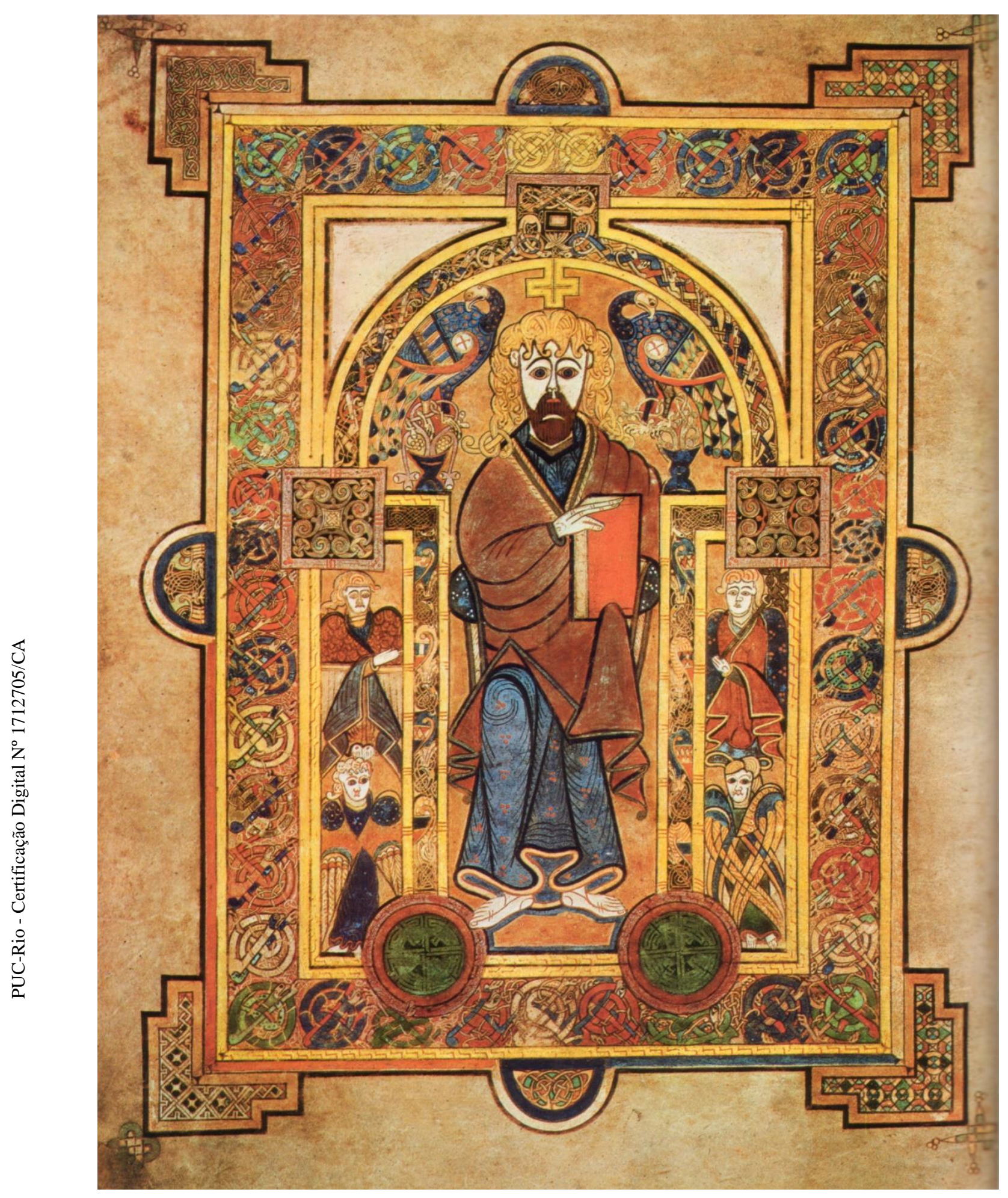

Figura 238: Iluminura do Livro de Kells 


\subsection{Iluminuras - uma arte para agradar aos olhos de Deus}

A iluminura é por excelência uma arte monástica. Faillace descreve-a como "uma das quatro invenções artísticas da Idade Média, assim como o vitral, o retábulo e a xilogravura" ${ }^{398}$, visto que, ao contrário do afresco e do mosaico, que foram herdados da antiguidade pagã e adaptados ao culto cristão, o desenvolvimento artístico das iluminuras deu-se entre os cristãos, no interior dos monastérios onde eram produzidos os manuscritos.

Vitrais e retábulos tiveram funções importantes dentro das igrejas, e a xilogravura merece destaque como a primeira arte de reprodução no Ocidente. A iluminura, por sua vez, é criação artística singular, que atingiu ápices de excelência pictórica e adaptou-se perfeitamente aos propósitos de diversos livros cristãos $^{399}$.

O estudo das iluminuras é desafiante devido ao seu caráter interdisciplinar, pois, além da pertinência no estudo da história da arte, pôde elucidar "todos os domínios da história social que eram influenciados pelos valores e crenças do cristianismo ${ }^{400 "}$. De fato, questões históricas diretamente ligadas à instauração dessa nova religião fomentaram tal feito e influenciaram sua estética, de modo que, além de inaugurar uma nova era, ao colocar a arte aos seus serviços, o cristianismo mudou seus paradigmas, inaugurando, também, um novo capítulo na história da arte. Para entendermos os ditames dessa nova arte, é preciso circunscrever o contexto histórico no qual ela se deu. O Império Romano caracterizou-se inicialmente como um império de diversidade e liberdade religiosa, uma vez que permitia aos povos por ele conquistados a prática de cultos e ritos oriundos de suas crenças, chegando até mesmo a absorver parte de suas culturas e de seus deuses, como sucedeu com a cultura grega, por exemplo. Em contrapartida, exigia-se que seus imperadores fossem reverenciados como deuses, o que, provavelmente, não era de todo impraticável no seio das religiões politeístas. Havia, entretanto, dentre essas inúmeras religiões politeístas, uma

\footnotetext{
398 FAILLACE, op. cit. (2016, p 21)

399 Ibid. (p 22)

400 Idem.
} 
religião monoteísta, a cristã, que descendia da hebraica, e tanto judeus como cristãos recusavam-se a adorar tais imperadores, visto que tal atitude confrontava sua ideologia ${ }^{401}$. A princípio esse povo monoteísta representava uma minoria, porém, com o tempo, o número de cristãos aumentou e eles espalharam-se por todo o continente. Diante dessa recusa à adoração dos imperadores romanos, nasce um grande conflito e tem início a perseguição ${ }^{402}$.

(...) quando Roma já se convertera num império, o busto de um imperador ainda era visto com religioso temor e reverência. Sabemos que todos os romanos deviam queimar incenso diante desse busto, como símbolo de sua lealdade e vassalagem, e que a perseguição aos cristãos ocorreu justamente porque eles se recusavam a cumprir tal exigência ${ }^{403}$.

Por conta de tal perseguição, esses primeiros cristãos passam a reunir-se em catacumbas subterrâneas formadas por longos corredores, onde, ao contrário dos demais que cremavam seus mortos, eles os enterravam. Ali, então, reuniam-se secretamente para dividir o pão, tomar o vinho e adorar seu deus único. Acontece que, frente à premência de contar a história de Cristo, eles começam a pintar essas catacumbas de acordo com as cenas descritas em seu evangelho, originando assim a arte paleocristã - ou arte cristã primitiva - conhecida nessa fase como catacumbária $^{404}$. Evidente que, a princípio, essa arte ainda sem identidade específica apropria-se dos padrões estéticos que conheciam, isto é, de referências artísticas do paganismo e da cultura greco-romana, no entanto, as preocupações estéticas da arte paleocristã apontavam noutra direção.

Os primeiros artistas chamados a pintar imagens para lugares cristãos de sepultamento - as catacumbas romanas - (...) estavam familiarizados com os métodos de pintura helenística usados em Pompeia. Eles eram perfeitamente capazes de evocar mentalmente a ideia de uma figura humana com meia-dúzia de pinceladas mais ou menos irregulares. (...) Mas esses efeitos e estratagemas não lhes interessavam muito. A representação pictórica deixara de existir como uma coisa bela por si mesma. Seu principal intuito era recordar agora aos fiéis um dos exemplos do poder e da misericórdia de Deus ${ }^{405}$.

\footnotetext{
401 Arte PaleoCristã Parte I - Fase Catacumbária, TV Cria Arte, 2018

402 Idem.

403 GOMBRICH, op. cit. (p 84) (2015, p 121)

404 Idem.

405 Ibid. (2015, pp 128-129)
} 
Logo de início, a arte paleocristã rompeu com o realismo e com o ideal de beleza dos corpos, pois seu intento não era o de representar a matéria ou as coisas deste mundo, e, sim, de algum modo retratar a alma, a fé, qual seja, a vida do espírito. Portanto, "tudo o que não fosse estritamente relevante era melhor deixar de fora (...) as ideias de clareza e simplicidade começavam a superar os ideais de fiel imitação ${ }^{406 \%}$. Ainda que, conforme observa Gombrich ${ }^{407}$, essa mudança de interesse não estivesse restrita às obras religiosas, pois “o ponto fundamental é que os artistas desse período já não estavam satisfeitos com o mero virtuosismo do período helenístico e tentavam agora obter novos efeitos”. A arte cristã tinha de fato um propósito educativo, e, considerando que os cristãos eram perseguidos, não podiam cumprir com sua missão abertamente; sendo assim, terminaram por encontrar um caminho pela arte ${ }^{408}$. Acontece que, ainda segundo Gombrich, os romanos eram um povo prosaico, atribuindo grande valor a uma narrativa clara e fiel na reprodução exata dos detalhes, e com isso desenvolveram um método pictórico de narrar suas façanhas, que terminou, inclusive, por influenciar outras religiões que entram em contato com sua cultura ${ }^{409}$.

\begin{abstract}
Mesmo na distante Índia, o modo romano de contar uma história e glorificar um herói foi adotado por artistas que se propuseram a tarefa de ilustrar a saga de uma conquista pacífica: a história de Buda. (...) Outra religião oriental que aprendeu a representar suas histórias sagradas para a instrução dos crentes foi a judaica. Na realidade, a Lei judaica proibiu a realização de imagens, por temor à idolatria. Não obstante, as colônias judaicas nas cidades da fronteira leste dedicaram-se à decoração das paredes de suas sinagogas com histórias do Antigo Testamento. Uma dessas pinturas foi recentemente descoberta numa pequena cidade de guarnição romana da Mesopotâmia, chamada Dura-Europos ${ }^{410}$.
\end{abstract}

\footnotetext{
406 GOMBRICH, op. cit. (p 129)

407 Ibid. (p 131)

408 Ibid. (p 128)

409 Idem.

410 Ibid. (p 128)
} 
Tais histórias ajudam-nos a compreender de que forma considerações religiosas semelhantes influenciaram a arte, ao mesmo tempo em que a colocaram a seu serviço. A representação pictórica, nesses casos, servia a um propósito educativo e exemplar. De forma que a arte primitiva cristã surge desde seus primórdios como uma arte narrativa, ilustrativa e simbólica, visto que a história que ela conta precisa ser, a um só tempo, oculta e revelada. A iconografia cristã surge justamente como fruto da criptocomposição (cripto, do grego, = esconder), isto é, uma composição plástica criada de forma a representar algo que não se pode mostrar, e ensinar sobre esse algo que está implícito naquela representação $^{411}$. Subjacente a tal desenvolvimento havia ainda uma questão de importância capital, que atravessava os cultos pagãos da antiguidade, e diante da qual a igreja precisava impor um novo posicionamento - a relação com a imagem. Essa matéria foi determinante para os rumos que a arte tomou no Ocidente e no Oriente. Gombrich desperta nossa atenção para o fato de que, ao lermos na Bíblia sobre como os profetas investiam contra a adoração dos deuses, não relacionamos tais palavras com fatos concretos. Não alcançamos a qual objetivo servia a arte grega.

\begin{abstract}
Quando visitamos as filas de estátuas de mármore branco da antiguidade clássica nos grandes museus, esquecemos muitas vezes que entre elas encontram-se os ídolos de que a Bíblia fala; que as pessoas oravam diante delas, que sacrifícios lhes eram oferecidos em meio a encantamentos, e que milhares e dezenas de milhares de adoradores delas aproximavam-se com esperança e medo em seus corações - interrogando-se, como diz o profeta (Jeremias X, 3-5), sobre se aquelas estátuas e ídolos não seriam realmente os próprios deuses ${ }^{412}$.
\end{abstract}

Dessa forma, nos é muito difícil mensurar o impacto de tais obras sobre esses adoradores ou que, mesmo hoje, teriam sobre nós, pois quase todas as estátuas do mundo antigo desapareceram, destruídas que foram após a vitória do cristianismo, que considerava um dever piedoso a destruição das estátuas dos deuses pagãos. As obras representativas desse período a que hoje temos acesso são, em sua maioria, meras reproduções "feitas no período romano para viajantes

\footnotetext{
411 Arte Paleocristã III - Simbologia, TV Cria Arte, 2018

412 Ibid. (p 128)
} 
e colecionadores, levadas como souvenirs e decorações para jardins ou banhos públicos". Para Gombrich ${ }^{413}$, se, por um lado, devemos ser gratos pela existência dessas réplicas, que ao menos "nos proporcionam uma pálida ideia das famosas obras-primas da arte grega", por outro lado, elas nos passam "a ideia generalizada de que a arte grega era inanimada, fria, insípida, e de que as estátuas gregas tinham aparência fria e olhar vazio que nos lembram obsoletas aulas de desenho ${ }^{414}$ ". Para nos aproximarmos do que seria uma visada mais realista, o historiador sugere aliarmos nossa imaginação às antigas descrições que nos chegam como ecos longínquos do que foram realmente essas obras. Com isso teremos, talvez, um vago vislumbre de sua magnificência, de modo a alcançar os efeitos provocados por tal miragem.

(...) uma gigantesca imagem de madeira, com uns 11 metros de altura, tão alta quanto uma árvore, toda coberta de materiais preciosos - a armadura e as vestes de ouro, a pele de marfim. Havia também grande profusão de cores fortes e brilhantes no escudo e em outras partes da armadura, sem esquecer os olhos, que eram feitos de pedras coloridas. O elmo dourado da deusa era encimado por grifos, e os olhos de uma enorme serpente enroscada dentro do escudo também eram destacados, sem dúvida, por refulgentes gemas ${ }^{415}$.

Sem sombra de dúvida, “devia ser uma visão fantástica, inspiradora de profundo respeito e reverência, quando alguém entrava no templo e, de súbito, via-se diante dessa estátua enorme" 416 , pois é fácil imaginarmo-nos hoje diante de tal visão, transbordando de admiração e espanto. Com tal projeção podemos compreender o empenho e a determinação que levou o cristianismo a destruir tais obras, a fim de impor o que acreditava ser sua missão, visto que, "Quanto mais realistas elas fossem, maior era o pecado contra o Mandamento que proibia imagens"417. Acontece que com o crescimento do número de cristãos que se espalham por todo o reino, em dado momento o próprio imperador Constantino converte-se ao cristianismo e decreta, em 313 d. C., o Édito de Milão -

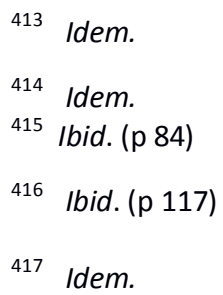


documento proclamatório que declara a tolerância do Estado em relação a todas as religiões -, e, portanto, proíbe a perseguição a toda e qualquer religião, especialmente aos cristãos. Então, quando o imperador Constantino estabelece que a igreja seria o poder supremo no reino, seu relacionamento com a arte foi necessariamente reexaminado frente à premência de se criarem locais adequados ao serviço religioso e à congregação de fiéis. O propósito dos antigos templos era completamente diferente, eles apenas dispunham de um sacrário para abrigar a estátua de um deus, e tudo o mais acontecia do lado de fora ${ }^{418}$.

Assim, aconteceu que as igrejas não usaram os templos pagãos como seus modelos, mas adotaram o tipo de amplos salões de reunião que, em tempos clássicos, eram conhecidos pelo nome de "basílica", o que significava "pórtico real". Esses edifícios eram usualmente mercados cobertos e recintos para audiências públicas dos tribunais. (...) A mãe do imperador Constantino erigiu uma dessas basílicas para servir de igreja, e por isso o termo foi instituído e oficializado para igrejas desse tipo ${ }^{419}$.

Os cristãos, que até então praticavam seu culto nas catacumbas abaixo da terra, ganham a liberdade para praticar seus cultos e começam a ocupar as basílicas. O próprio Constantino manda erigir duas basílicas - a basílica Constantina, hoje basílica de São Pedro, e a igreja de São João de Latrão. A arte paleocristã sai então dessas catacumbas subterrâneas para as abóbadas das basílicas com o mesmo propósito: contar a história de Cristo ${ }^{420}$. Nessa fase, a arte cristã primitiva fica conhecida como Arte Basílical ${ }^{421}$. Com o fim da perseguição há uma aproximação com os ideais clássicos de Roma, e, assim, a arte cristã, embora continue negando o realismo e sendo, sobretudo, uma arte ilustrativa e simbólica, termina por desenvolver uma estética em que se fundem o paganismo e o cristianismo, passando a representar também os ideais clássicos da Antiguidade.

Ocorre que a decoração dessas basílicas suscitou violentas disputas e controvérsias, pois, junto à demanda, ressurgia o problema geral da imagem e de seu uso na religião. Segundo Gombrich, os primeiros cristãos devotos

\footnotetext{
418 Ibid. (p 133)

419 Idem.

420 A igreja Santa Maria Maior, que foi alterada inúmeras vezes; preserva, todavia, um belíssimo conjunto de mosaicos inalterados, portanto, mosaicos paleocristãos da fase basílical. Arte Paleocristã Parte II - Fase Basílical, TV Cria Arte, 2018
} 
concordavam com o seguinte ponto: "não devia haver estátuas na Casa do Senhor ${ }^{422 \%, ~ u m a ~ v e z ~ q u e ~ a s ~ m e s m a s ~ f a t a l m e n t e ~ l e m b r a r i a m ~ a s ~ i m a g e n s ~ e s c u l p i d a s ~}$ dos deuses pagãos, e isso a Bíblia condenava. Ademais, provavelmente, estar diante de uma estátua que "representava" Deus, da mesma forma que traria reminiscências indesejadas dos antigos e inadequados cultos, poderia dificultar a compreensão da mensagem de um Senhor que se colocava como Uno, Onipotente e Invisível, e a cuja semelhança fomos $\operatorname{criados}^{423}$. Todavia, as opiniões sobre a pintura eram divergentes, e havia os que defendiam o uso da pintura como forma de manter viva a memória dos episódios sagrados. Essa foi a perspectiva adotada pelo Império Romano Ocidental. A posição do papa Gregório Magno, ainda que um pouco mais tardia do que esses episódios ora relatados, ilustra bem a perspectiva.

O papa Gregório Magno, que viveu no final do século VI, seguiu essa orientação. Lembrou àqueles que eram contra qualquer pintura que muitos membros da Igreja não sabiam ler nem escrever (...) disse ele: "A pintura pode fazer pelos analfabetos o que a escrita faz pelos que sabem $1 \mathrm{le}^{424}$.

O posicionamento de uma autoridade tão poderosa foi determinante para os ditames da nova arte, pois a maior parte da arte desenvolvida durante o medievo foi de cunho religioso. Já as regiões orientais de fala grega do Império Romano eram absolutamente contrárias ao uso de qualquer imagem, independentemente de sua natureza, com o que surgem os iconoclastas ou destruidores de imagens. Por outro lado, havia ainda uma outra linha de pensamento antagônica para a qual as imagens eram acima de tudo sagradas - os bizantinos. Com essa perspectiva, a arte bizantina, com o propósito de glorificar o Cristo e seu poder, procurou preservar e de alguma forma dar continuidade, grandeza e esplendor à antiga arte do Oriente. Assim, o posicionamento dessa outra facção religiosa foi também de suma importância para a história da arte. Todavia, cabe observar e refletir que em outras searas do Oriente - Islã e China, territórios em que fazer imagens era absolutamente proibido -, a arte encontrou

\footnotetext{
422 GOMBRICH. op. cit. (p 135)

424 Idem.
} 
outros caminhos ${ }^{425}$. Os artífices do mundo islâmico criaram, através da tessitura de padrões e formas abstratas, ornamentações extremamente delicadas, sutis e elaboradas, que se tornaram conhecidas no Ocidente, sobretudo pelos arabescos em seus tapetes. Para Gombrich, o olhar do artista, ao ser desviado dos objetos do mundo real, teria encontrado esse fascinante mundo onírico de linhas e cores. ${ }^{426}$ Tempos depois, a proibição de feitura de imagens ficou restrita aos temas religiosos; com isso, surgiram belíssimas e encantadoras ilustrações de romances, histórias e fábulas, ricas em detalhes refinadíssimos, oriundos, certamente, da prática de se fazer arte com linhas, formas e cores. Na China, a religião, assim como no Ocidente e no Oriente Médio, também foi fortemente impactada pela arte, entretanto suas práticas, influenciadas pelo budismo, tinham outro propósito, pois, ainda que as histórias de Buda e outros mestres chineses também tenham sido narradas pela arte religiosa chinesa, a perspectiva era outra, não se pretendia com ela doutrinar seus fiéis, como no cristianismo, e sim propor através da arte religiosa um caminho para prática da meditação - eixo central da religião chinesa $^{427}$. Provavelmente por isso, o chinês foi o primeiro a colocar o pintor no mesmo nível de um poeta inspirado.

Os artistas devotos começaram a representar água e montanhas num espírito de reverência, não com o intuito de ensinar lições, nem meramente fazer decoração, mas com a finalidade de fornecer material para uma meditação profunda. Seus quadros em rolos de seda eram guardados em recipientes preciosos, e eram contemplados e meditados da mesma forma que se poderia abrir um livro de poesia e reler um belo verso. (...) Aprenderam inclusive sua arte por um estranho método de meditação e concentração em que adquiriam primeiro a habilidade (...) estudando as obras de mestres famosos, e não a própria natureza. Só quando já tinham adquirido grande habilidade é que começavam a viajar e a contemplar as belezas naturais a fim de captar o espírito da paisagem. Quando voltavam para casa, tentavam então recaptar esses estados de espírito, reunindo suas imagens de pinheiros, rochedos e nuvens, exatamente como um poeta alinhando uma série de imagens que the acudiam ao espírito no decorrer de um passeio $^{428}$.

\footnotetext{
425 Ibid. (p 143)

426 Idem.

427 Ibid. (p 150)

428 Ibid. (p 153)
} 
Esses exemplos servem-nos para ilustrar e constatar a primazia e o poder da imagem para a religião, que ou a trouxe para perto de si ou procurou bani-la. De qualquer forma, seja qual for o estilo ou a estética com que a arte se tenha expressado nesse período, a questão da imagem x religião foi determinante para os caminhos que seguiu.

A arte monástica - a partir da qual surge e desenvolve-se a iluminura configurou-se quando, de acordo com a proclamação do Édito de Tessalônica em 380 d.C. pelo imperador Teodósio - o último a governar o Império Romano por inteiro -, o cristianismo passou a ser a religião oficial do Império Romano. Com isso, a situação outrora vivida pelos cristãos inverte-se e começam as perseguições aos cultos pagãos. Ocorre que, com a cisão do império em Império Romano do Ocidente e Império Romano do Oriente, a parte oriental transforma-se no Império Bizantino, e a parte ocidental é derrubada em 476 d.C. pelos povos bárbaros que invadem toda a Europa. Contudo, uma instituição romana sobrevive à queda do império e mantém-se em pé - a igreja católica -, tornando-se na época a guardiã da língua, da leitura, dos livros e dos conceitos estéticos de beleza da Antiguidade clássica. O cristianismo, então, realiza um movimento aparentemente contraditório, pois, ao mesmo tempo em que a igreja busca a expansão através da cristianização dos bárbaros, há um movimento de interiorização através da vida monástica que se instaura com a criação dos mosteiros e concretiza-se na vida reclusa dos monges que renunciam à vida profana ${ }^{429}$.

O primeiro mosteiro surge em Cairo, no deserto do Egito em 350 d.C. - o Mosteiro de Santo Antão. Por sua vez, o primeiro mosteiro construído em território ocidental é fundado na Itália em 529 d.C. por São Bento - o Mosteiro de Monte Cassino. São Bento funda a Ordem dos Beneditinos, e esses monges espalham-se pela Europa e constroem outros tantos mosteiros que se caracterizam como locais de reza, oração e trabalho voluntário, onde, para se viver, havia a obrigatoriedade dos votos de silêncio, castidade, pobreza etc. Os monges que ali viviam dedicavam sua vida a Cristo e viviam de acordo com os preceitos de sua fé. $\mathrm{E}$, além disso, produziam arte $\mathrm{4}^{430}$.

\footnotetext{
${ }^{429}$ Arte Paleocristã Parte II - Fase Basílical, TV Cria Arte, 2018

${ }^{430}$ Idem.
} 
Foi no interior desses mosteiros que surgiu uma expressão artística que, a priori, não fora produzida com nenhum propósito mundano, e tampouco estava endereçada aos olhos da multidão. Diferente da arte grega que outrora produzia suas estátuas para serem contempladas por todos, havia antes um propósito decorativo e devocional, no qual "toda a beleza da apresentação era destinada a Deus" ${ }^{\sharp 31}$. Assim sendo, o livro, no culto cristão, um elemento essencial que constitui a base da igreja cristã, o desígnio sagrado de tal arte consistia em adornar os altares e tornar seus livros sagrados belos para os olhos de Deus.

(...) sobre a natureza das iluminuras, no primeiro período da Idade Média, pertenciam mais à arte decorativa do que propriamente à ilustração. Os desenhos eram feitos com a intenção de decorar o livro e não de ilustrar o texto: dessa forma, é frequente que as ilustrações dos manuscritos nada tenham com o seu assunto, ao contrário do que modernamente se pratica ${ }^{432}$.

Não por acaso, em muitas imagens cristãs, temos Jesus Cristo e outros tantos santos representados com o livro na mão, cena que seria inimaginável junto aos antigos deuses pagãos. O livro traz a história cristã e a palavra de Deus, e, portanto, além de essencial, é sacralizado e protegido pela igreja, visto que, como objeto frágil, precioso e raro, necessitava de proteção contra as invasões dos bárbaros, que não o entendem porque não são capazes de decifrá-lo. Portanto, tais livros não tinham sequer o propósito de educar os povos que assolavam toda a Europa: eram produzidos e "iluminados" no interior dos mosteiros, em silêncio e oração, pois, apesar do propósito doutrinador da igreja através do uso das imagens com cunho narrativo e simbólico, os monges copistas encarregados de realizar as iluminuras, na prática, envolviam-se em um processo que poder-se-ia dizer meditativo. "Mais do que um simples trabalho de ordem material, a cópia de manuscritos assumia foros de exercício espiritual (...) ${ }^{433}$ ".

O pintor que iluminasse esses textos realizava uma tarefa que ia muito além do âmbito artístico: seria como dar à luz um conteúdo sagrado, para além das palavras, com ouro e cores aplicados sobre desenhos sofisticados. A luminosidade de

\footnotetext{
${ }^{431}$ FAILLACE, op. cit. (2016, p 73)

${ }^{432}$ Idem.

${ }^{433}$ MARTINS, op. cit. (1957, p 102)
} 
Cristo tornou-se um preceito teológico que deveria ser sensível como uma experiência ao mesmo tempo religiosa e estética ${ }^{434}$.

Desse modo, "Toda a beleza da apresentação era destinada a Deus ${ }^{435 "}$. Contudo, à medida que tal expressão artística vai se desenvolvendo, termina por sair do domínio dos mosteiros, passando a ser produzida também por iluminadores laicos que se estabelecem, junto a outros copistas e livreiros, em oficinas próximas às universidades ${ }^{436}$. Tais livros, com o tempo, são reconhecidos como a maior expressão da chamada arte menor, que vigorou na Europa durante o medievo, e assim designada devido ao tamanho de suas peças, que precisavam ser, sobretudo, portáteis - punhais, cabos de espadas, peças de ourivesaria etc. -, visto que, nesta época, havia muitos povos de culturas diversas, dentre os quais muitos eram nômades ou estavam a circular devido às guerras e ocupações territoriais que caracterizam a época ${ }^{437}$. Considerando que todas as civilizações expressam-se através da arte, e cada uma delas trazia uma característica artística própria, tal arte designada como menor devido a sua necessidade primária de portabilidade ganhou, em contrapartida, uma minuciosidade, uma riqueza de detalhes realmente impressionante e grandiosa. De alguma forma, o mesmo sucedeu com a arte das iluminuras. Livros também são portáteis, peças bem menores do que estátuas ou os monumentos de outrora, e alguma sinergia deu-se entre a arte profana e sagrada de então, de forma que a grandiosidade dessa arte minuciosa permeou a ambas.

\footnotetext{
434 FAILLACE, op. cit. (2016, p 21)

435 Ibid. (p 72)

436 Idem.

437 Idem.
} 


\title{
3.2 Iluminuras - especificidades, processos, estilos
}

\begin{abstract}
A iluminura não é apenas uma pintura realizada com minuciosa sofisticação e materiais preciosos. Não é, meramente, uma "representação" de figuras de devoção e cenas bíblicas ou hagiográficas. Ela constitui uma modalidade de cultura visual cuidadosamente elaborada para ser apresentada dentro de um livro. É concebida no seio de um livro e não pode ser plenamente compreendida fora desse contexto ${ }^{438}$.
\end{abstract}

No interior de todo monastério existia um scriptorium ${ }^{439}$, lugar onde os monges desenvolviam o intenso trabalho de compilação de manuscritos, transcrevendo-os, ilustrando-os e encadernando-os, sobretudo para a comunidade religiosa $^{440}$. A demanda crescente por cópias e a necessidade de uniformizá-las segundo um determinado padrão geraram uma organização rigorosa e especializada de trabalho, na qual atuavam diversos monges ${ }^{441}$. Era a partir dos livros antigos, traduzidos ou não, que se produziam os novos livros. Não por acaso, o monge copista chamava-se antiquarius ${ }^{442}$; os noviços aprendizes ou os monges menos hábeis, chamados librarii e scriptorii ${ }^{443}$, executavam os trabalhos mais simples e pouco minuciosos como moer as tintas, traçar as pautas nos infólios e dobrá-los em cadernos ${ }^{444}$; já os trabalhos mais complexos ou as obras tidas como as mais importantes destinavam-se ao bibliographius, calligraphius ou antiquarius, conforme a competência requerida ${ }^{445}$. Dentre eles, os melhores calígrafos eram encarregados dos trabalhos sofisticados, geralmente encomendados por dignitários da nobreza ou do clero. Uma vez que o texto estivesse pronto, a decoração era obra dos especialistas em ilustração -

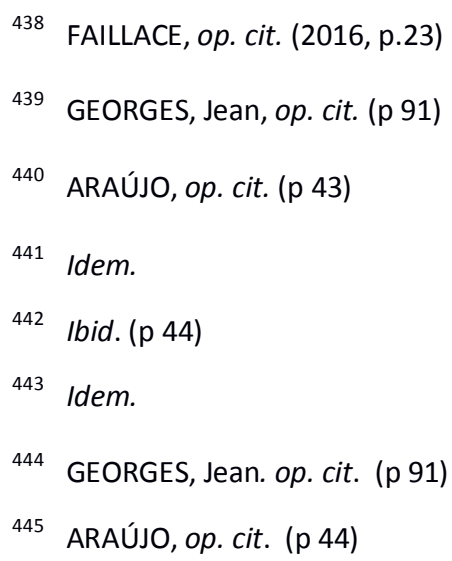


illuminatores, miniatores e rubricatores -, até que por fim, chegava ao encadernador, o illigatorlibrorum. O armarius ou bibliothecarius era uma espécie de supervisor editorial a quem cabia a coordenação e direção do trabalho ${ }^{446}$. A formação de um escriba era extremamente especializada e das mais exigentes, levando pelo menos sete anos de aprendizado com um mestre-artesão ${ }^{447}$. Ademais, para ser iluminador era preciso também aprender a processar os materiais e os pigmentos para o preparo das tintas ${ }^{448 .}$ Todavia, ao contrário dos escribas egípcios que gozavam de grande reputação, o monge copista não tinha reconhecimento social, e por isso havia casos de artistas talentosos que entravam para a vida religiosa a fim de exercer sua arte sem preocupações materiais ${ }^{449}$.

Artistas de gênio, eles eram capazes de executar não somente as "letras capitulares" em folhas de ouro que abriam cada parágrafo ou capítulo, mas também desenhos de flores, personagens, paisagens de cores vivas das miniaturas que ilustram os mais belos desses livros ${ }^{450}$.

Algumas dessas obras consumiam a vida toda de um monge para serem realizadas e, ainda assim, por vezes, ficavam inacabadas ${ }^{451}$. O trabalho de feitura de um manuscrito, além de extremamente especializado e colaborativo, demandava tempo, pois, além da transcrição do texto e ornamentação do mesmo, havia o preparo inicial da matéria-prima para o suporte, e, na última fase, era preciso reunir os cadernos para encaderná- $\operatorname{los}^{452}$.

O processo todo consistia inicialmente na preparação do pergaminho, geralmente o velino - do francês arcaico, veel, vitelo (bezerro) -, que, obtido do tratamento da pele de bezerros recém-nascidos ou natimortos, tinha a qualidade de não absorver demasiadamente a tinta ou a pintura, e, assim, melhor conservar o

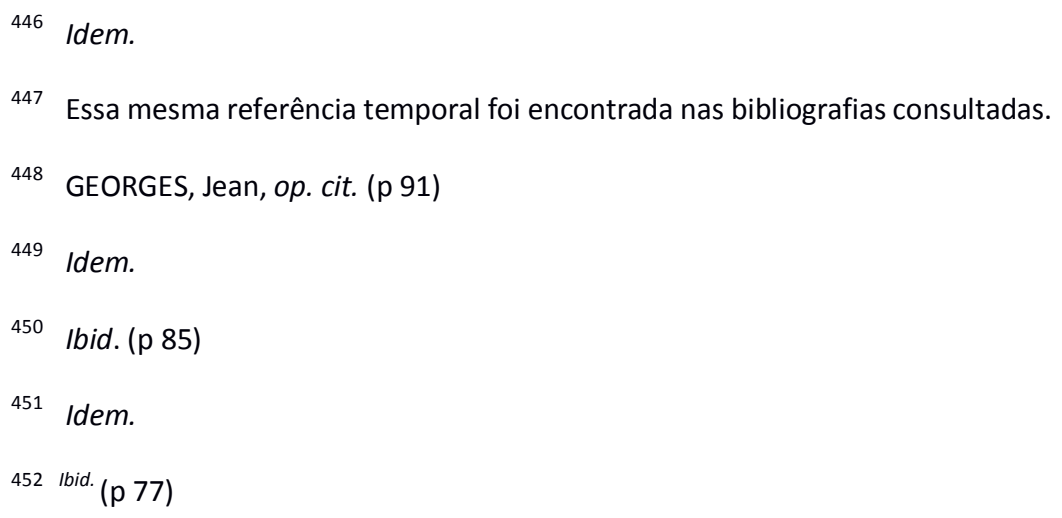


colorido original $^{453}$. Esse suporte era tratado pelo pergaminarius, especialista em peles, que os preparava para a escrita cortando-os em dado formato de modo que suas folhas reduzidas a um tamanho comum pudessem ser polidas e acetinadas ${ }^{454}$. Os noviços e os aprendizes eram encarregados de traçar as linhas, "pautas", sobre as quais os escribas fariam as cópias e alinhariam o texto cuidadosamente cotejado com o original por um revisor. Eram traçadas primeiro com ponta seca, e depois com o lápis (subsistem ainda numerosos manuscritos em que as pautas não foram apagadas) ${ }^{455}$, e então liberadas aos iluminadores, miniaturistas e rubricadores, que faziam as cópias dos títulos, e traçavam as iniciais em vermelho $^{456}$, nos espaços livres reservados para as capitulares e ilustrações, seguindo, em geral, indicações sobre as composições que deveriam decorar ou ilustrar o texto ${ }^{457}$. O motivo era, de início, esboçado com um buril; depois os detalhes eram indicados com pena de ganso e tinta, utilizando-se, quando necessário, compasso, régua e esquadro. Os contornos em cor eram também executados com a pena; somente o "preenchimento" era feito com pincel fino ${ }^{458}$. O encadernador, em geral, reunia os cadernos e produzia a capa finamente trabalhada em madeira, couro e fecho. Havia, entretanto, "encadernações luxuosas, feitas com materiais valiosos como ouro, prata, marfim, pérolas, e pedras preciosas" $" 459$. que, segundo Faillace, refletiam a riqueza do encomendante, pois “eram comparadas a um relicário que protegia e adornava o valioso objeto" ${ }^{, 460}$.

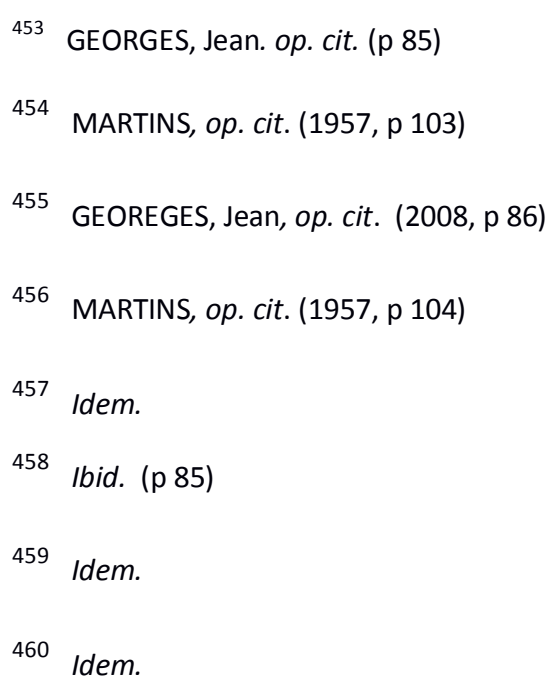


Quase todos os livros traziam fechos e marcadores esmaltados com flores, esculpidos com cabeças de animais e cravejados de pérolas e pedras preciosas. Os mais valiosos guardavam-se em camisas de damasco e defendiam-se do atrito com cravos de cobre pregados no dorso ${ }^{461}$.

As ilustrações, que valorizaram sobremaneira esses livros, distinguiam-se em iluminuras e miniaturas. Segundo o parecer de Martins, tais designações eram inicialmente sinônimas, considerando que as miniaturas, mais simples em sua elaboração, eram traçadas em uma única cor, o vermelho. O termo 'miniatura' inclusive, não advém do tamanho dessa arte, como pode parecer ao senso comum, e, sim, deriva da tinta vermelha, na época composta de mínio e cinábrio - o vocábulo miniatura origina-se do termo hispânico vulgarizado do latim minium, vermelhão, cinábrio, de onde minius, 'vermelho, encarnado ${ }^{, 462}$ - com a qual eram traçadas as letras capitulares e as figuras, que, quando menos sofisticadas, reduziam-se a essa cor. Assim, conforme descreve Faillace, "por miniatura entende-se qualquer desenho, letras ornadas e historiadas, vinhetas espalhadas pelo texto, cenas pintadas, pinturas de página plena etc., escritos ou pintados com as cores originais do mínio (cor vermelha) ${ }^{463}$ ". O miniaturista ou rubricador desenhava as capitulares cujo interior era ornamentado com floreios, volutas e arabescos, bem como as rubricas de final de capítulo ou de parágrafo, predominantemente em vermelho, para acentuar o destaque, tal qual eram feitas nos papiros egípcios ${ }^{464}$. Já a iluminura propriamente dita poderia ser compreendida como uma evolução ou aperfeiçoamento da miniatura, visto que a iluminura não compreende apenas a aplicação de minium nas letras e nas figuras, e sim abundância e variedade de cores - o azul, o amarelo, e, no século XII, o verde -, que pouco a pouco juntaram-se ao vermelho originário, até que, por fim, além das tintas, aplicavam-se finas folhas de ouro ${ }^{465}$. Esses detalhes "iluminados" eram "resultante da fixação de uma folha de ouro de espessura bem fina colocada sobre uma camada de revestimento feito de uma mistura de gesso, açúcar e

\footnotetext{
461 FAILLACE (Rizze apud Faillace), op. cit. (2016 p.77)

462 ARAÚJO, op. cit. (2008, p 448)

463 FAILLACE, op. cit. (2016, p 72)

464 ARAÚJO, op. cit. (2008, p 448)

465 Ibid. (p 113)
} 
chumbo aplicada sobre a página e que seca ligeiramente na superfície" ${ }^{\star 466}$. Segundo Georges Jean, tal revestimento deveria ser suficientemente flexível para atender aos seguintes propósitos: “dobrar com a página sem rachar e, uma vez misturado com água e clara de ovo, permitir que a pena corresse livremente" ${ }^{\text {467 }}$. "Paralelamente, toda a arte do desenho passa por um refinamento" 468 , de modo que, das letras iniciais coloridas e ornamentadas com complexos arabescos, a decoração foi gradualmente ocupando toda a página, não se limitando apenas às capitulares onde já se desenhavam imagens completas no interior das letras, mas também espalhando-se pelas margens com diversas ornamentações, e ainda, com composições de cenas que eram totalmente independentes do texto ${ }^{469}$.

Svend Dahl diz sobre a natureza das iluminuras, no primeiro período da Idade Média, que pertenciam mais à arte decorativa do que propriamente à ilustração. Os desenhos eram feitos com a intenção de decorar o livro e não a de ilustrar o texto: dessa forma é frequente que as ilustrações dos manuscritos nada tenham com o seu assunto, ao contrário do que modernamente se pratica (...) os autores costumam assinalar que muitos livros piedosos são ornados com gravuras bastante livres, da mesma forma que os animais fantásticos ofereciam motivos para o desenho das iniciais, sem que o leitor procurasse entre uma coisa e outra a menor correlação ${ }^{470}$.

Com a crescente especialização, a técnica da miniatura ficou reservada "para as letras ornadas, muitas vezes formadas por figuras fantásticas de animais mitológicos ou de homens, aves, peixes e flores, enquanto a técnica da iluminura passou a corresponder à ilustração propriamente dita ${ }^{471}$ ", tornando-se, já na época de Carlos Magno, uma arte magnífica. ${ }^{472}$ A história da iluminura distingue-se em duas fases - hierática e naturalista. Na primeira fase, a ilustração não tem o

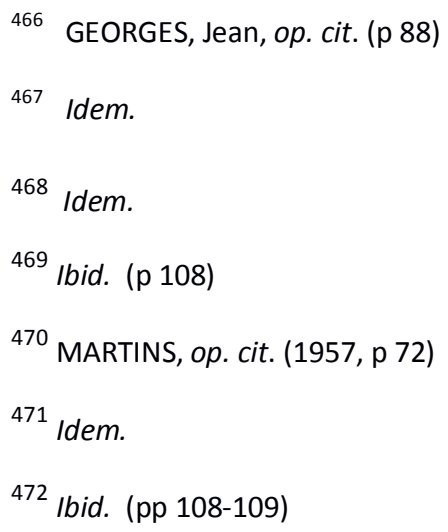


propósito de ilustrar ou copiar a realidade, o que prevalece é o simbolismo, e o trabalho de feitura é impregnado pelo sentido do sagrado ${ }^{473}$.

(...) ele decorará cuidadosamente as iniciais, traçará desenhos de puro ornamento, e a fantasia lhe inspirará, por vezes, encantadoras ideias; mas o cúmulo de seu talento, o supremo no gênero consistirá em fazer com que as coisas mais simples digam o que elas não dizem aos ignorantes. Por exemplo, ao pintar um Cristo crucificado, não se preocupará em fazer escorrer naturalmente o sangue das feridas, nem de representar a cena do Calvário, tal como deve ter passado em realidade. Ele terá em vista, acima de tudo, o sentido místico da cena; e fará escorrer o sangue divino em um cálice sustentado por uma mulher: será a Igreja recolhendo os frutos da paixão do Salvador. Uma mão significará Deus, um peixe, o Cristo batizado $^{474}$.

O livro manuscrito na Europa ocidental divide-se, grosso modo, em dois grandes períodos: monástico e laico. No período dito monástico, que compreende a queda do Império Romano até o século XII, de fato, os mosteiros e outros estabelecimentos eclesiásticos detinham o monopólio quase integral da cultura da palavra escrita e da produção de livros, na qual o propósito era fixar e difundir a palavra de Deus e dos Santos, e, por conseguinte, nas iluminuras prevalece o caráter simbólico. Entretanto, no século XII, com a instituição das universidades e crescente educação entre os leigos, ocorre uma profunda transformação social, cultural e intelectual, e a necessidade crescente de livros para atender essa nova demanda ocasiona mudanças nas formas como os livros eram compostos ${ }^{475}$. Nesse período dito laico, inicia-se nova fase na história da iluminura - a naturalista -, pois, um novo estado de espírito modifica a perspectiva dessa arte que passa então por um processo de "profanização", ${ }^{476}$ prenunciando a revolução que se estabeleceria entre os séculos XIV e XV.

As artes e as letras começam a se secularizar; o mecenato típico da segunda fase da Idade Média começa a se exercer, deslocando dos conventos para os castelos uma parte dos

\footnotetext{
${ }^{473}$ Idem.

474 Ibid. (pp 108-109)

475 FEBVRE, MARTIN, op. cit. (2017)

476 MARTINS. op. cit. (1957, p.109)
} 
trabalhos intelectuais. (...) o artista começa a representar os seus personagens com os traços $\mathrm{e}$ as roupas dos seus contemporâneos; a cor local aparece e os pormenores típicos. O simbolismo cede lugar ao realismo ${ }^{477}$.

É nessa nova fase que o esplendor do manuscrito ilustrado chega ao auge, perdurando até o século XV, quando "a iluminura transforma-se em verdadeira pintura e dá, mesmo, nascimento à pintura moderna ${ }^{478 \%}$. Durante todo o período em que tais livros eram produzidos a mão, sobretudo entre os séculos $\mathrm{V}$ e $\mathrm{XV}$, houve vários centros de referência dedicados a intenso trabalho editorial, cada qual com diferenças estilísticas e iconográficas próprias, dentre os quais destacam-se os estilos insular e carolíngio ${ }^{479}$.

As primeiras ilustrações notáveis na Europa foram as dos códices angloirlandeses, com estilo insular desenvolvido nessa região da Europa, sendo também encontradas no reino dos francos e em algumas regiões da Europa Continental, sobretudo nas comunidades criadas pelos celtas, de onde se originou esse estilo artístico. $^{480}$

[...] embora influenciados pela ilustração bizantina, incorporaram o estilo celta na sua iconografia, em que espirais entrelaçadas, arcos que se transformavam em curvas serpentinas e cabeças de dragões e outros animais fantásticos embutiam-se nas maiúsculas e no próprio corpo do texto ${ }^{481}$.

A principal característica das iluminuras insulares é a possibilidade de se fazer duas leituras, pois, ao olhar para seu conjunto, inicialmente temos a impressão de estar diante de uma imagem abstrata ou, ao menos, de uma composição complexa, repleta de detalhes, arabescos, rendilhados, volutas, linhas e formas geométricas etc., que compõem uma espécie de labirinto. Entretanto, ao adentrarmos o olhar nas entrelinhas que compõem esse labirinto, desvelamos um mundo subjacente, um outro nível de decoração que pode prender nossa atenção

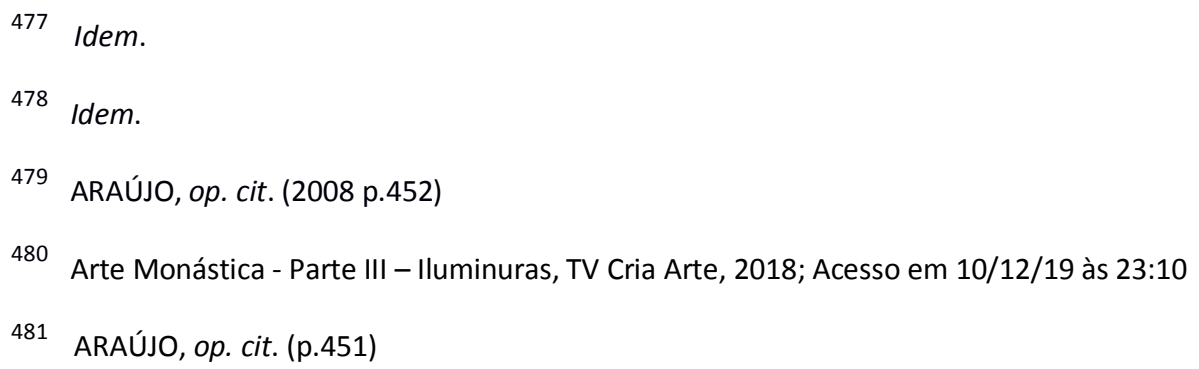


por horas inteiras, em consequência da riqueza de detalhes que encontramos aí. Outra especificidade marcante é seu caráter extremamente simbólico ${ }^{482}$.
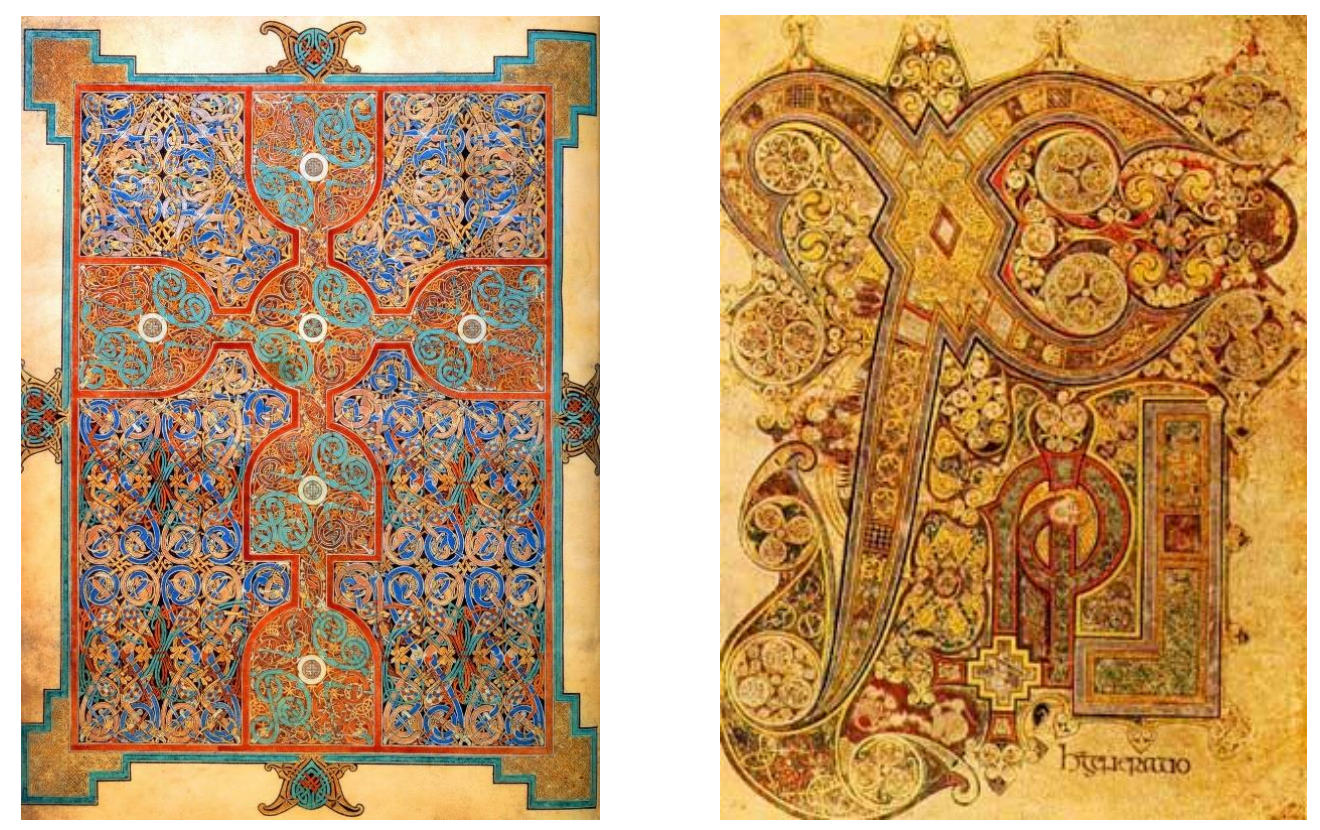

Figura 249: Iluminura do Evangelho de Lindisfame / Figura 30: Iluminura do Livro de Kells

Nesta iluminura do Evangelho de Lindisfarne, produzida no mosteiro de Lindisfarne no século VII, inclui os evangelhos de S. Mateus, S. Marcos, S. João e S. Lucas - temos a representação, por exemplo, de uma cruz que se sobrepõe a um labirinto rendilhado onde há várias espécies de animais, dragões, serpentes, vegetais etc., simbolizando que a cruz, e tudo o que ela representa, sobrepõe-se a toda essa vida que pulsa por baixo.

Outra iluminura exemplar e das mais famosas, é a o Livro de Kells, com ornamentação extremamente delicada e minuciosa em torno de duas letras gregas. Aliás, não se trata de uma capitular - inicial de um texto totalmente ornamentada -, mas sim de um monograma composto a partir dessas duas letras gregas que significam: $\mathrm{X}=$ qui / $\mathrm{P}=$ hô, isto é Qui hô - Cristo escrito em grego. Chama-se "Monograma da Encarnação", e representa Deus vivo. Nessa iluminura também identificamos dois níveis de leitura, uma vez que, por baixo do nome de Cristo Qui hô - há rostos de anjos, insetos, animais, vegetais, enfim, todo um mundo

482 Arte Monástica - Parte III - Iluminuras, TV Cria Arte, 2018 Acesso em 11/12/19 às 00:37 
subterrâneo que pulsa sob o poder de Deus. Conhecido também como Evangelho de São Columba, o Livro de Kells foi produzido na Irlanda no século IV. Ainda que inacabado, é considerado por todos uma obra de arte por excelência, o exemplo maior e supremo da arte monástica - suas páginas são espetacularmente importantes na história da arte, tanto as páginas completamente ilustradas, como as páginas textuais, e seu valor comercial, inestimável ${ }^{483}$.

O texto em caligrafia maiúscula insular é impecável (...), impossível não se maravilhar com o traçado da pena. (...) a decoração é mais extensiva e arrebatadora do que se possa imaginar. Praticamente toda linha é adornada com cores ou ornamentos. Toda sentença começa com uma inicial caligráfica complexa preenchida com elementos artísticos policrômicos, como joias incrustadas de esmalte. Frequentemente consistem (ou têm nelas incluídas) formas de animais e criaturas estranhas ${ }^{484}$.

Hugh MacDiarmid"485 (1892-1978), diz em um verso do "The Poetic Faculty”, que o Livro de Kells só pode ser estudado com um microscópio, experiência que ele próprio teve oportunidade de realizar e da qual comenta ser “extraordinário o que ele revela nos mínimos detalhes ${ }^{486 "}$. A propósito, foram feitos experimentos entre escribas modernos para estudar de que modo as volutas e entrelaçamentos teriam sido desenhados, e "mesmo que se apare uma pluma com uma ponta muito fina, é uma realização técnica quase inimaginável"487.

Em diversos compêndios de arte insular, encontra-se com frequência uma descrição medieval que se tornou citação comum para descrevê-la. Gerald de Gales (1146-1223), viajante e cronista, descreve sobre um "precioso manuscrito que lhe haviam mostrado cheio de figuras e ornamentos, que chegava a ser arrebatador $^{488,}$.

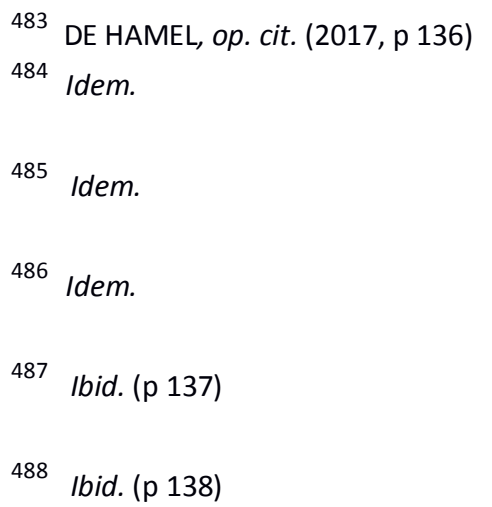


(...) "se você se der ao trabalho de olhar bem de perto", escreve ele, "e fizer seus olhos penetrarem nos segredos de sua arte, vai perceber tantas complexidades, tão delicadas e sutis, tão próximas umas das outras, e tão bem tricotadas, tão envolvidas e unidas, e ainda tão frescas em seus coloridos, que não hesitará em declarar que todas essas coisas devem ter sido obra não de homens, mas de anjos" ${ }^{489}$.

Enquanto o estilo insular estabelece-se nessas regiões, no resto da Europa desenvolvia-se um estilo que ficou conhecido como carolíngio, devido à influência do imperador Carlos Magno. Pretendendo unificar toda a Europa, e inspirado pela figura do primeiro grande imperador romano, Constantino, converteu-se ao cristianismo e idealizou que toda a expressão plástica de seu grande império deveria restabelecer os ideais clássicos da época do Constantino. Com isso houve uma espécie de renascimento de tais padrões. A arte carolíngia tem algumas características que nos remetem à arte bizantina, tais como as representações bidimensionais e frontais, contornadas por vinhetas e com menos detalhes em seu entorno.

Nesse âmbito está circunscrita uma das iluminuras mais analisadas do mundo, pois, além de remeter ao período helenístico, possui uma plasticidade inédita proporcionada pelo uso da pena de ganso, alcançada posteriormente apenas com os pincéis. Ademais, sua expressão remete ao movimento expressionista que surgiu muito depois, durante a arte moderna. ${ }^{490}$ Para Gombrich $^{491}$, essa iluminura do evangelário de Ebbo (830 d.C), inaugura um novo estilo de arte medieval:

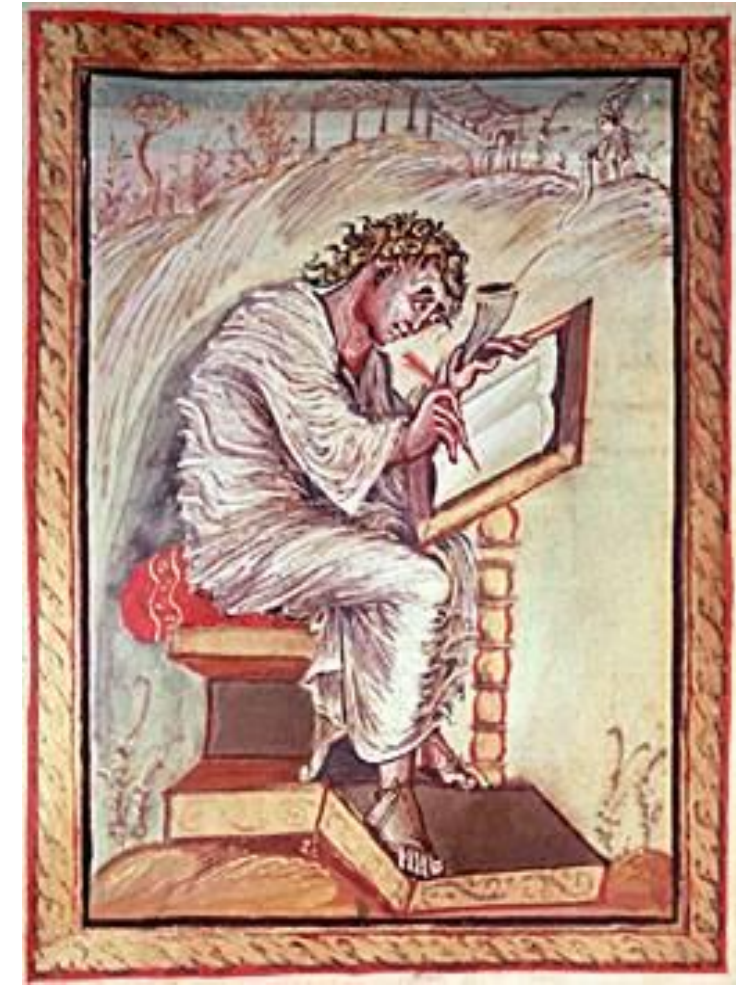

Figura 251: Iluminura do Evangelário de Ebbo

\footnotetext{
489 Idem.

490 Arte Monástica - Parte III - Iluminuras, TV Cria Arte, 2018 Acesso em 17/02/2019 as 05:54

491 GOMBRICH, op. cit. (p 165)
} 
(...) que possibilitou à arte fazer algo que nem a antiga arte oriental e nem a arte clássica tinham feito". Os egípcios haviam desenhado principalmente o que sabiam existir, os gregos o que viam; na Idade Média, o artista aprendeu também a expressar em seu quadro o que sentia ${ }^{492}$.

Com o advento da prensa gráfica de Gutenberg, em torno de 1450, o livro impresso substitui a produção manuscritora, e o livro manuscrito desaparece. Portanto, "a partir do século XV, pode-se dar como terminado o período histórico dos manuscritos e sua ilustração ${ }^{493}$ ". 


\title{
4. LIVRO DE / DO ARTISTA - A nova arte de fazer livros
}

\begin{abstract}
Este livro [pesquisa] deseja fazer um diálogo com o território específico e abrangente do livro de artista, atualmente com suas fronteiras ampliadas. Aqui trazemos à tona algumas reflexões e projeções, entre tantas possíveis, sobre o campo semântico que a expressão livro de artista alavanca, carregando em seu bojo sutis e avassaladoras distinções: livro-objeto, objeto-livro, caderno de anotações, diários, impressos, obra-livro, forma-livro, caixa-livro, livroprocesso, livro-registro, entre outras ${ }^{494}$.
\end{abstract}

\subsection{Considerações do campo}

No capítulo anterior apresentamos a história e o desenvolvimento do códice, cuja estrutura essencial continua vigente no modelo de livro que conhecemos atualmente, e, por meio de sua evolução, a elaboração da arte da caligrafia - criação artística singular do medievo ${ }^{495}$ - que, ornada de maravilhosas iluminuras, constituía o principal trabalho artístico da Europa ocidental ${ }^{496}$, alcançando ápices de excelência pictórica ${ }^{497}$, e dando mesmo nascimento à pintura moderna ${ }^{498}$. Reconhecidamente, as iluminuras são um capítulo da história da arte; entretanto, não podemos esquecer que fazem parte de "uma modalidade de cultura visual cuidadosamente elaborada para ser apresentada dentro de um livro ${ }^{499,}$, de forma que, uma iluminura medieval designa, via de regra, o manuscrito medieval iluminado, circunscrito nesta pesquisa como modelo de livro raro. Mesmo com o declínio provocado pelo advento do livro impresso, o papel da iluminura continua sendo preponderante, permeando de alguma forma a constituição do campo que recoloca na história o livro como obra de arte. Algumas considerações, entretanto, fazem-se necessárias.

\footnotetext{
494 DERDYCK, Edith. Entre ser um e ser mil - o objeto livro e suas poéticas. In "Entre páginas e não páginas: breve inventário de livros de artista" por Galciani Neves. São Paulo: Senac, 2013.

${ }^{495}$ FAILLACE, op. cit. (2016, p 22)

496 Ibid. (Fischer apud Faillace, p 73)

497 Ibid. (p 22)

${ }^{498}$ MARTINS, op. cit. (1957, p 112)

${ }^{499}$ FAILLACE, op. cit. (2016, p 23)
} 
Antes de tudo é preciso esclarecer que nossa aproximação ao livro de artista não se dará ao seu sentido stricto - como produto específico da arte conceitual na década de 60 -, pois, ainda que tal status tenha sido reconhecido durante esse período e sob tal paradigma, diante do enorme potencial plástico do livro de artista e das múltiplas linguagens que ele acolhe, consideramos tal abordagem reducionista, e, portanto, contrária ao propósito de contemplá-lo em seu sentido lato. Também não iremos contemplar (e muito menos analisar) os inúmeros exemplos da profusão de livros de artista que representam o que poderse-ia chamar de campo infinito, para isso seria necessário, em seu sentido stricto, uma ampla pesquisa, coisa que já se coloca paradoxal diante de seus múltiplos, e fugiria ao escopo da pesquisa.

Para fundamentar tal perspectiva trazemos inicialmente a fala de Yves Peyré $^{500}$ autor de Peinture et Poésie - le dialogue par le livre 1874-2000, no qual descreve e analisa 126 livros de artistas representativos de seus 126 anos de história. O período em questão está compreendido entre o que seria, para o autor, o marco histórico de origem, 1874 - quando dois poetas, Charles Cros e Mallarmé, e um pintor, Manet, formulam a ideia que se concretiza em $1875^{501}$, com a composição de Le Corbeau, trazendo Edgar Allan Poe como autor, Stephane Mallarmé como tradutor, Edouard Manet como artista, Richard Lesclide $^{502}$ como editor/organizador, e o ano de publicação de seu próprio livro, 2000.

Peyré defende a ideia do livro como espaço propício para encontro e diálogo entre pintura e poesia ${ }^{503}$, e considera espantoso que essa fórmula tenha atravessado o século em processo contínuo de renovação e aprofundamento,

\footnotetext{
${ }^{500}$ PEYRE, Yves. Peinture et Poésie - le dialogue par le livre 1874-2000. Paris: Editions Gallimard, 2001. O autor é diretor da Biblioteca Literária Jacques Doucet, além de escritor de ensaios sobre pintura, poesia, história e também autor de poemas.

501 Ibid. (2000, p 6)

502 Richard Lesclide foi um editor reconhecido com um dos primeiros, se não o primeiro, a incentivar e fomentar o livro de artista. Além de Le Corbeau (1875), citado por Yves Peyré, editou O Rio, que traz Charles Cross como autor e Edouard Manet como artista. Yves Peyré cita Charles Cross como poeta fundador do livro de artista, mas não cita essa obra. https://data.bnf.fr/12127836/richard lesclide/ Acesso em 18/08/2019 às 19:53

${ }^{503}$ Diríamos, entre imagem e texto, ou, entre linguagem visual e linguagem escrita, de modo a evitar uma leitura estreita desses termos, a qual pode conduzir a uma armadilha de interpretação contrária à essência do enunciado.
} 
reinventando-se continuamente sem perspectiva de esgotar-se, e acredita que isso aconteça justamente devido ao potencial infinito que não se deixa circunscrever por conceitos específicos que cerceariam sua múltipla e criativa expressão ${ }^{504}$. Para ele, isso é indicativo de que há, todavia, uma história em curso, na qual o convencional é rejeitado; por conseguinte, a tônica preponderante é da busca e experimentação $^{505}$. Na sua visada, o primado em tal arte está sobretudo no vis-àvis, no jogo do eco, no diálogo ativo, que mais do que estabelecer hierarquias abrem espaço para o essencial a que pintura e poesia dialoguem na criação ${ }^{506}$. Para ele, o encontro da escrita e da pintura na plasticidade do livro enriqueceu esses dois modos de expressão, desvelando uma arte em si ${ }^{507}$. Tal fenômeno é justamente a especificidade do campo, seu eixo central, sem o qual tal arte não seria possível.

O princípio que guiou sua abordagem ao campo foi o encontro de dois criadores (um poeta, um pintor) em um espaço comum, o livro ${ }^{508}$. Com base nessa premissa, ele contrapropõe o conceito de Livre d'dialogue aos conceitos tradicionalmente atribuídos ao campo - livre de peintre, livre d'art, livre d'artist $\mathrm{e}$ livro ilustrado -, argumentando que tais denominações do campo teórico revelaram-se de alguma forma reducionistas ao priorizarem determinadas fórmulas em detrimento de seu potencial criativo e inovador. No caso do livro ilustrado, por exemplo, espera-se que a imagem esteja subordinada ao texto, exercendo a função menor de iluminá-lo; e no livro de artista, ao contrário, espera-se que a imagem detenha obrigatoriamente a primazia sobre o texto, quando este existir ${ }^{509}$. Com base na crítica e concepção colocadas por Peyrè, justifica-se a discussão ainda vigente em torno das premissas, datação e conceitos relativos ao campo. Em toda a bibliografia consultada nas décadas de 1970, 80, 90 e no século XXI, há divergências conceituais e formais sobre o que é, e quais são os limites do livro de artista.

\footnotetext{
${ }^{504}$ PEYRE, op. cit. (2000, p. 218)

${ }^{505}$ Idem.

${ }^{506}$ Ibid. (p 6)

${ }^{507}$ Idem.

${ }^{509}$ Idem.
} 
O conceito é ainda muito problemático, pondo em xeque pesquisadores com pesquisadores, artistas com artistas, e pesquisadores com artistas, além de envolver outras especialidades, como estética, literatura, biblioteconomia e comunicação ${ }^{510}$.

Ademais, não se pode desprezar que desde a década de 60 até agora (2019), transcorreu mais de meio século, e o livro de artista, consonante com "as perspectivas do futuro" previstas por Peyré ${ }^{511}$ há 19 anos - por ocasião da publicação de seu livro (2000) -, continua surpreendendo e reformulando-se a cada nova edição, saindo obviamente da esfera da arte conceitual. Por outro lado, é preciso ver: "as evidências demonstram que, na busca da origem do livro de

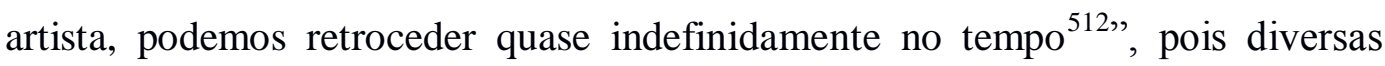
referências reconhecidas como precursoras, não fora por limitações de ordem teórica, poder-se-iam reconhecer como tal.

A título de ilustração podemos citar os primeiros códices mesoamericanos - eram principalmente pictóricos e apresentavam uma estrutura formal artisticamente elaborada ${ }^{513}$. O Códice Bourbônico por exemplo, datado aproximadamente do século $\mathrm{V}$, além de portar conteúdo da maior importância para a cultura asteca, apresenta formato semelhante aos livros do tipo "biombo" que são dobrados como uma sanfona e destacam-se hoje no âmbito do livro de artista, com o diferencial de ter aproximadamente $15 \mathrm{~m}$ de comprimento $(!)^{514}$. Outros inúmeros exemplos, realizados em períodos diversos e anteriores à formulação teórica, embora não circunscritos em seu sentido stricto, inquestionavelmente pertencem ao campo.

Assim como também o são os livros de William Blake, publicados entre 1788 e 1821 , ou qualquer dos cadernos de Leonardo da Vinci, executados no século 15 e começo do 16, sem possibilidade de publicação ${ }^{515}$.

\footnotetext{
510 SILVEIRA, op. cit. (2008, pp 25-26)

511 PEYRE, op. cit. In "Entrevision du Futur". (2000, p 218)

512 VENEROSO, Maria do Carmo Freitas. In "Perspectivas do livro de artista, um relato". Belo Horizonte: UFMG, v.2 n.3 2012.

513 LYONS, op. cit. (2011, p 86)

514 Idem.

515 SILVEIRA, op. cit. (2008, p 30)
} 


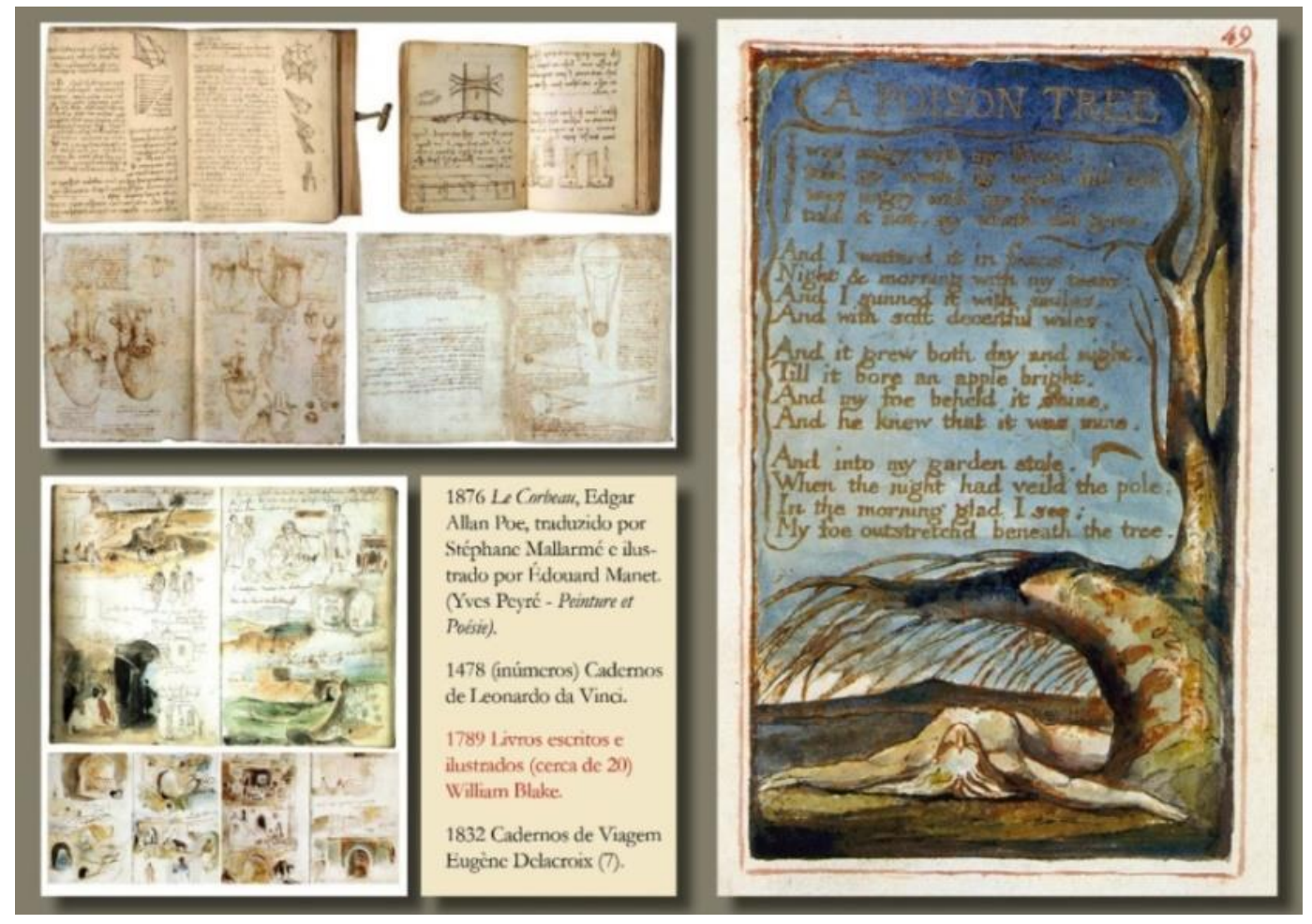

Figura 262: Precursores do Livro de Artista

(...) também o livre de peintre, que surge em meados de 1890, como uma iniciativa do marchand Ambroise Vollard, em Paris, pode ser considerado um precursor do livro de artista (...) Fausto, de Goethe e Delacroix, é também um dos mais conhecidos exemplos desse tipo de publicação $(\ldots)^{516}$.

Portanto, em concordância com o parecer de Peyré, temos o intento de valorizar a arte do encontro entre imagem e texto como uma arte em si, no espaço generoso oferecido pelo livro para diálogo e troca, sem cair na disputa pela hierarquia de um território que é, desde suas origens, franqueado e propício a essas duas formas de expressão aparentemente contraditórias ${ }^{517}$. Com esse propósito vamos contemplar, sobretudo, quais as premissas e especificidades que atendem à qualificação de um livro de artista em seu sentido lato; o potencial plástico e criativo que o campo oferece, como e por que essa fórmula surgiu na contramão da crescente massificação do processo de feitura do livro, resgatando assim a arte de fazer livros com arte.

\footnotetext{
516 VENEROSO, op. cit. (v.2 n.3 2012)

517 Ver no capítulo 2. "Manuscrito medieval iluminado" dessa dissertação, a seção "revisitando origens imagens e letras".
} 

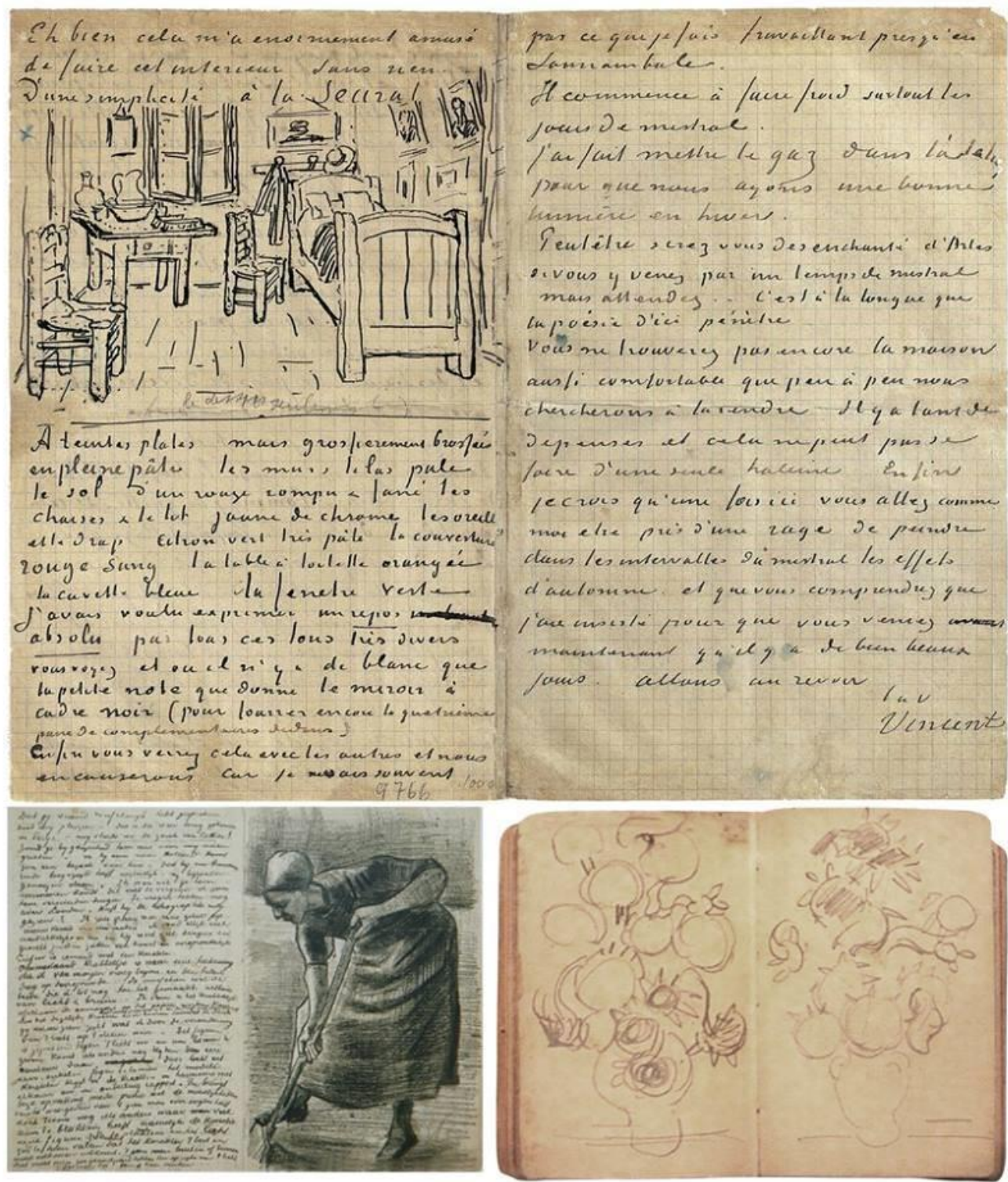

Figura 273: Caderno de esboços de Van Gogh 


\subsection{Dos manuscritos iluminados à ilustração editorial}

O processo que afastou o livro impresso do livro manuscrito deu-se aos poucos, à medida que se foi tomando consciência do potencial do novo sistema de produção e, efetivamente, do alcance que o novo modelo foi conquistando. Nessa transição, a necessidade, e, por conseguinte, a imposição de novas tecnologias, foi preponderante para a mudança de perspectiva na qual o livro deixa de ser visto e produzido como objeto precioso e sagrado, vindo a ser um objeto comum e portátil; contudo, a "coisa" livro não perdeu (e nem poderia) seus atributos plásticos intrínsecos, de modo que seguiu, sem pretensão, sendo território fértil aos processos artísticos.

Na seara das inovações técnicas que surgiram com o intento de dar conta das demandas de impressão de imagens para o livro impresso, o campo da gravura, embora preexistente, foi sendo largamente incrementado, e desenvolveuse a ponto de conquistar autonomia como categoria artística. $\mathrm{O}$ alto desenvolvimento de técnicas de reprodução da imagem somado à colaboração de grandes artistas gravadores produziu obras-primas a serviço do livro; por outro lado, houve uma crescente massificação da imagem impressa, suscitando reações de grande importância no domínio das artes gráficas. Na raiz dessa contradição encontra-se a semente que germinou o campo do livro de artista.

Entender tais desdobramentos é fundamental para a compreensão do como e por que o livro, depois de perder valor artístico, conquista o status de obra de arte na categoria que se instaura na arte moderna, consolidando-se como tal no período da arte contemporânea; de forma que a história continua como fio condutor.

Inicialmente, a invenção da prensa gráfica e dos tipos móveis não provocou nenhuma transformação na aparência do livro; o âmbito específico de sua revolução deu-se no alcance proporcionado pela rapidez da reprodução com custos cada vez mais baixos, o que teria engendrado a democratização do conhecimento outrora restrito à nobreza e ao clero. Portanto, o que se distingue como a grande "revolução do livro" aponta especificamente para a revolução 
causada através do livro ${ }^{518}$, na medida em que, tornando acessíveis a qualquer pessoa pensamentos, ideias e conhecimento, passa a ser "não apenas objeto capaz de armazenar informações, mas sujeito das transformações sociais que ocorreram a partir da invenção da imprensa e da multiplicação dos escritos pela tipografia ${ }^{519,}$.

O livro impresso tem sido um dos meios mais poderosos para a disseminação de ideias, e mudou o curso do desenvolvimento intelectual, cultural e econômico da humanidade. (...) A simples amplitude do conhecimento preservado nas bibliotecas somada ao número de publicações produzidas anualmente impossibilitanos um mundo sem livros. Sua influência e efeitos são incomensuráveis; no ano 2000, Gutemberg foi eleito o indivíduo mais significativo do último milênio pelos eleitores do jornal britânico The Times ${ }^{520}$.

Ao que tudo indica, os primeiros impressores, por diversas razões, não tinham intenção alguma de inovar o seu aspecto, muito pelo contrário, seu propósito era imitá-lo o mais perfeitamente possível, utilizando, inclusive, segundo Febvre e Martin $^{521}$, grupos de letras com as mesmas ligaduras das manuscritas. As iniciais continuaram sendo rubricadas e iluminadas a mão por copistas e iluminadores mediante um espaço que lhes era reservado, de modo que a produção manuscritora seguiu paralela à evolução da imprensa durante um bom tempo. Por conseguinte, os primeiros incunábulos - os primeiros livros impressos - tinham a mesma aparência dos manuscritos. Mesmo depois do surgimento das novas técnicas de ilustração que efetivamente substituíram as iluminuras e miniaturas, os editores especializados no âmbito dos livros de luxo mandavam ilustrar o texto impresso da mesma forma e com os mesmos artistas que iluminavam os manuscritos ${ }^{522}$. Dentre as diversas hipóteses para justificar tal continuidade no design desses novos modelos, para Febvre e Martin ${ }^{523}$ o fator

\footnotetext{
${ }^{518}$ Quanto a isso, em toda a bibliografia consultada há unanimidade entre os autores.

${ }^{519}$ GOMBERG, Felip. "A aura do livro na era de sua reprodutibilidade técnica". Dissertação de Mestrado do Departamento de Comunicação Social da PUC-Rio, 2006.

520 HASLAM, Andrew. O livro e o designer II - Como criar e produzir livros. São Paulo: Rosary, 2007. (p 12)

521 FEBVRE e MARTIN, op. cit. (2016, p 101)

522 Ibid. (p 122)

${ }^{523}$ Ibid. (pp 101-103)
} 
preponderante estaria radicado no fato de que o manuscrito era o modelo vigente, e preservar sua identidade consistia, além de prova da conquista técnica, garantia para a vitória comercial.

Acontece que com o estabelecimento efetivo do novo processo atrelado à democratização e crescente popularização do livro, surgiu a necessidade de encontrar novos caminhos para iluminar os textos, visto que o tempo e o ritmo da produção manufatureira já não eram mais condizentes com a nova tecnologia ${ }^{524}$. Portanto, os novos meios de ilustrar os textos desenvolveram-se justamente com o propósito de dar continuidade à tradição da composição e diálogo entre imagem e texto, acompanhando, porém, o ritmo imposto pela nova tecnologia.

O uso de repertórios iconográficos como veículo para "ilustrar" o texto antecede de muito o livro impresso. Na tradição manuscritora, em que se fixaram alguns padrões específicos quanto à disposição das imagens na página, foram marcantes os papiros do Egito faraônico e os códices medievais. É claro que se poderia também falar, por exemplo, das magníficas ilustrações chinesas ou pré-colombianas, mas elas não tiveram qualquer influência, nem mesmo remota, na constituição das técnicas e das normas que orientam a relação texto-iconografia nos incunábulos europeus ${ }^{525}$.

Naquela época já existia um processo mecânico de reprodução em série das imagens, que se mostrou capaz de acompanhar o ritmo da impressão dos textos, vindo a atender o desejo e a necessidade de decorar centenas de exemplares impressos - a xilogravura ${ }^{526}$. A gravura em madeira já era conhecida e utilizada em alguns países da Europa - Alemanha, Bélgica, Países Baixos, Suíça, França e Itália -, nos quais as primeiras ilustrações impressas em papel traziam em comum uma imagística popular de grande aceitação ${ }^{527}$. Essas estampas xilográficas, segundo Araújo ${ }^{528}$, surgiram primeiro em baralhos (Alemanha 1377), depois em santinhos (entre 1418 e 1423), e finalmente, entre 1430 e 1440, as

\footnotetext{
524 ARAúJO, op. cit. (2000, p 453)

525 Ibid. (p 443)

526 FEBVRE, MARTIN, op. cit. (2000, p 122)

527 LYONS, op. cit. (2008, pp 55-58)

528 ARAÚJO, op. cit. (2008, p 456)
} 
matrizes xilográficas foram utilizadas para impressão de livrinhos populares conhecidos como livros 'tabulares' ou 'xilográficos'. "As impressões eram obtidas de dois modos: ou se aplicava o papel sobre a matriz gravada (...) ou se usava uma prensa $(. . .)^{529}$, , de modo que não havia obstáculo técnico para inserir na composição de caracteres tipográficos uma matriz xilográfica.

Como o método da xilogravura de transferir tinta para o papel com imagens em relevo na madeira fosse idêntico ao dos tipos móveis em metal, houve um ajustamento perfeito, nesse último caso, entre a gravura e texto, de tal modo que ambos se imprimiam tipograficamente a um só tempo ${ }^{530}$.

Na China e no Japão a impressão já era praticada há muito tempo; a propósito, a invenção do papel, sem a qual a prensa gráfica não poderia ter ido tão longe, também surgiu entre os chineses. Henri-Jean Martin ${ }^{531}$ descreve, inclusive, que os coreanos teriam inventado uma forma de tipos móveis - anteriores aos gutenberguianos - "de uma quase alucinatória similaridade àqueles de Gutenberg ${ }^{532}$, , e acredita, a partir desse dado, que a invenção ocidental pode ter sido estimulada por notícias a respeito de tal feito que teriam ventilado do Oriente. Lyons também descreve como "a impressão xilográfica - às vezes usando tipos móveis - foi usada na China no século XI e na Coreia no século XIII ${ }^{533}$,, e defende a tese de que "avanços tecnológicos como a invenção do tipo móvel não surgem do nada. (...) não foi como o momento de 'eureka' (...), mas o resultado de um processo cumulativo de inovação tecnológica ${ }^{534 "}$. Não obstante, ele acredita que Gutenberg nada soubesse sobre tais realizações. Peter Burke ${ }^{535}$ reconhece não haver realmente um marco zero do começo da história, entretanto, reconhece o papel preponderante de Johann Gutenberg, o que justifica sua importância.

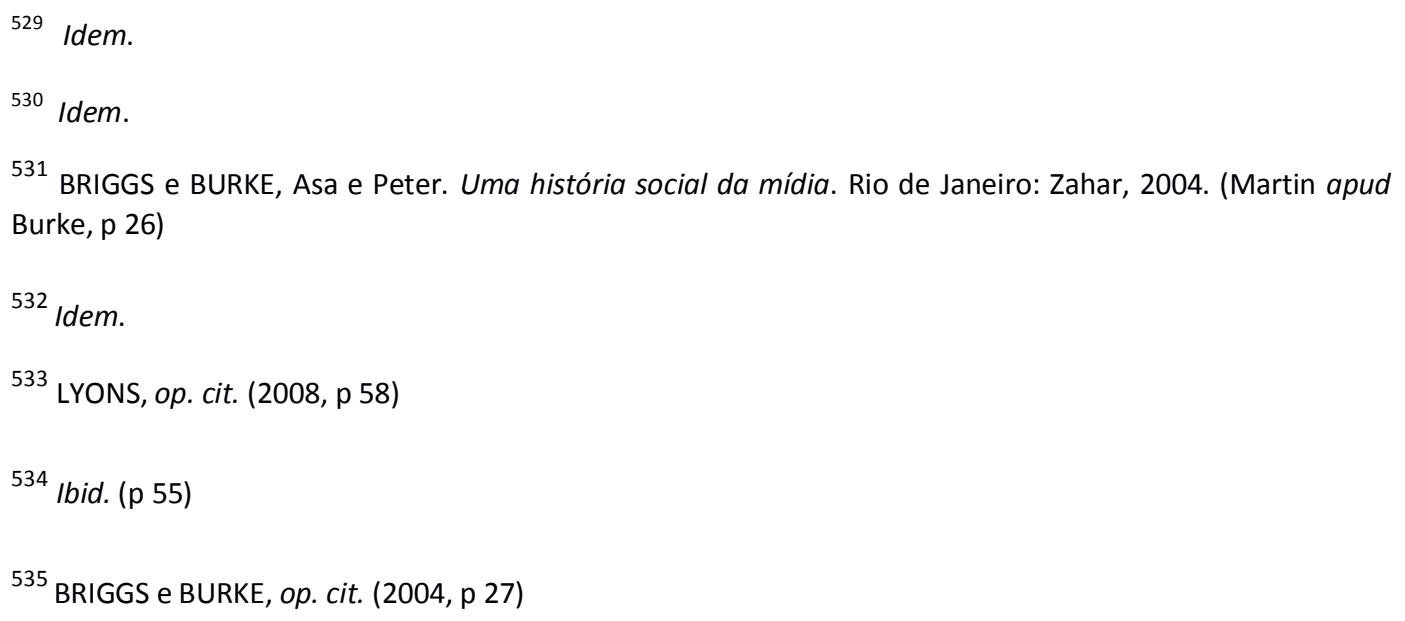


Ressalta, todavia, que não fossem as condições socioculturais propícias à disseminação da palavra escrita, qual seja, do livro impresso, a revolução oriunda desse processo combinatório que se deu entre a invenção do papel, da prensa gráfica, dos tipos móveis (do desenvolvimento da tinta apropriada para entintar as matrizes etc.), e a história teria sido outra, visto que, em outras regiões, tais como na Rússia, no mundo muçulmano e até mesmo na China, terra originária das primeiras impressões, não houve os mesmos desdobramentos. Trazendo como exemplo a Rússia:

O fato de os materiais impressos terem chegado tão tarde à Rússia (cerca de dois séculos depois) mostra que a revolução da impressão gráfica não era um fator independente e não se ligava somente à tecnologia. Essa revolução precisava ter condições sociais e culturais favoráveis para se disseminar, e a ausência da população laica letrada na Rússia foi um sério obstáculo para o surgimento, na região, da cultura impressa ${ }^{536}$.

Realmente, o contexto sociocultural foi determinante, afinal existia uma demanda anterior originária do advento e difusão das universidades e da erudição humanista por onde começou a laicização do livro; ademais, a ascensão das cidades e dos centros comerciais gerou um mercado consumidor de impressos ${ }^{537}$. De qualquer forma, a contribuição do lastro oferecido pela invenção do papel, somada ao arranjo entre matrizes xilográficas e tipos móveis, encontrou solo fértil no Ocidente. Segundo Burke ${ }^{538}$, já por volta de 1500 , isto é, apenas meio século após a invenção dos tipos móveis e da prensa gráfica, o novo sistema havia-se estabelecido em mais de 250 lugares na Europa, e, juntas, essas primeiras gráficas haviam produzido nada menos que 27 mil edições, o que significa, "estimando-se uma média de 500 cópias por edição - que cerca de 13 milhões de livros estavam circulando em uma Europa com cem milhões de habitantes ${ }^{539}$ ". Nessas oficinas

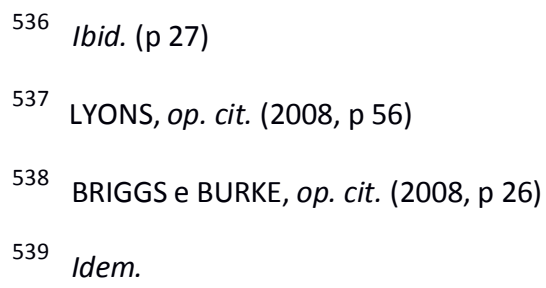


gráficas que se multiplicaram tão rapidamente pela Europa, a xilogravura rapidamente passou a ser associada à tipografia ${ }^{540}$.

O primeiro livro impresso ilustrado - Edelstein (A Pedra Preciosa), de Ulrich Boner - produzido por um impressor de Bamberg, Alberto Pister, foi publicado por volta de 1461, isto é, poucos anos depois da invenção da imprensa.

As figuras desse primeiro livro ilustrado, simples, sem sombreado, facilmente coloridas a aquarela, na sua rudeza, não eram desagradáveis à vista: o seu aspecto não deve ter surpreendido o público a que a obra se destinava - esse mesmo para quem tantas xilografias tinham sido executadas ${ }^{541}$.

Outras obras populares foram ilustradas e multiplicaram-se rapidamente. Ainda assim, subsistiu em diversos livros, até o século XIX, a prática de colorir a mão, "não só as ilustrações como as letras capitulares, as vinhetas no texto e os ornatos marginais da página ${ }^{542 \%,}$ o que sugere o valor e a receptividade estética atribuída aos livros ilustrados. Aliás, inseridos como estamos em uma cultura na qual a imagem massificada e banalizada toma-nos de assalto a cada instante, é difícil mensurar o auxílio inestimável das imagens impressas para o crescimento do mercado gráfico, mas certamente seu impacto foi imenso, visto que, como Varela $^{543}$ destaca, "a gravura trouxe uma característica inédita até então, de objeto

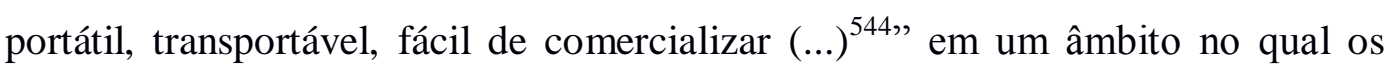
meios de criação de imagens em vigor eram as pinturas sobretudo religiosas afrescos, vitrais, tapeçarias etc. -, isto é, imagens públicas e circunscritas ao seu local de instalação.

Contudo, ainda que a apropriação e aperfeiçoamento da técnica da xilogravura para produzir essas ilustrações tenham-se dado sob o propósito de ocupar o lugar outrora ocupado pelas iluminuras, sua função e valor diferenciamse, pois as imagens nesses novos livros, reproduzidas por processo menos

\footnotetext{
540 CARDOSO, Pedro Sánchez. "A Lithos Edições de Arte e as transições de uso das técnicas de reprodução de imagens". Dissertação de Mestrado em História Social da Cultura. PUC-Rio, 2008. (p 16).

541 FEBVRE, Martin, op. cit. (2000, p 124)

542 ARAÚJO, op. cit. (2008, p 457)

543 VARELA, Marcos Baptista. "A Xilogravura Expressionista Brasileira”. Dissertação de Mestrado em História da Arte. Escola de Belas-Artes, Universidade Federal do Rio de Janeiro, 1997. ( $p$ 34)

544 Idem.
} 
refinado, passaram a ter, em geral, uma função coadjuvante: "nessas obras tratase, antes de mais nada, de explicar o texto, torná-lo concreto, e não tanto construir obra de artista" ${ }^{, 54}$, como havia acontecido outrora. Diferente dos manuscritos medievais iluminados, nos quais a interação imagem-texto era muito mais rica e equilibrada, e predominava uma estética simbólica e decorativa que dava margem a outras leituras.

Progressivamente, por questões formais de estilo ou função, o paradigma na arte de ilustrar mudou: a ilustração diminuiu de tamanho consoante ao novo formato dos livros; os ilustradores tiveram de conformar o estilo da imagem de acordo com uma multiplicidade de variedade tipológica; o simbolismo religioso outrora predominante foi substituído por imagens documentais, didáticas ou de ocasião ${ }^{546}$. Ademais houve mudança de perspectiva importante oriunda da colaboração e coautoria que passaram a existir entre autor vivo e ilustrador ${ }^{547}$. Outro fator preponderante na construção do novo paradigma foi que com o crescente alfabetismo provocado pelo advento da imprensa, a ilustração passou a ter um caráter pedagógico, ficando muitas vezes restrita ao didatismo a que se propunham publicações das mais diversas - compêndios de história natural, coleções de emblemas, livros de retratos, obras sobre astronomia e comércio, tratados de arquitetura, cartografias, diários de viagens, crônicas etc. -, nas quais, em geral, abundavam ilustrações, mais sob o caráter quantitativo do que qualitativo. O conceito de ilustração editorial strictu sensu, desde então, ficou circunscrito à função da imagem de "legendar" o texto; via de regra, tal ideia vigora no livro impresso até hoje.

Num livro, a ilustração é geralmente uma imagem figurativa, utilizada para acompanhar, explicar, acrescentar informação, sintetizar ou simplesmente decorar um texto. (...) tendo-se desenvolvido por meios mecânicos, fotomecânicos e, mais recentemente, digitais, com os recursos da computação e das novas tecnologias da editoração eletrônica. (...) se refere tanto a reproduções de desenhos e pinturas como fotografias ${ }^{548}$.

\footnotetext{
545 FEBVRE, Martin, op. cit. (2000, p 122)

546 ARAÚJO, op. cit. (2008, p 454)

547 Idem.

548 Ibid. (p 443)
} 
Ao mesmo tempo em que o crescente alfabetismo imprimiu um teor didático às ilustrações, elas deixam de ser imprescindíveis nos livros destinados ao público em geral, passando a figurar sobretudo em categorias específicas. Ainda assim, estima-se que "aproximadamente um terço das 30 a 35 mil obras

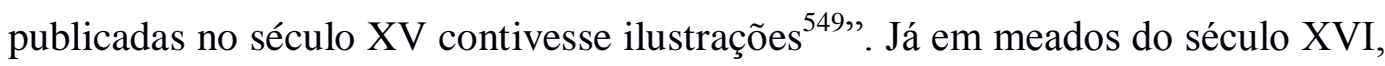
graças à imprensa e à efervescente multiplicação dos textos, o livro adquire mais estritamente a aparência que tem ainda hoje, passando aos poucos a fazer parte do lugar comum ${ }^{550}$.

O livro deixa de ser visto como objeto precioso que se consulta em uma biblioteca: deseja-se cada vez mais poder andar com ele e transportá-lo com facilidade para consultá-lo ou lê-lo em qualquer momento. Daí o êxito crescente dos "formatos portáteis", na primeira metade do século XVI - numa época, aliás, em que os clérigos, os estudiosos e os grandes senhores deixam de ser, cada vez mais, os únicos a interessarem-se pelos livros, e em que muitos burgueses formam suas bibliotecas ${ }^{551}$.

549 Ibid. (p 453)

${ }^{550}$ FEBVRE, Martin, op. cit. (2000, pp 101-118)

551 Ibid. (p 120) 


\subsection{O desenvolvimento do campo da gravura e a massificação da imagem impressa}

Se por um lado a instauração de processos mecânicos e seriados provocou uma perda da artisticidade que até então fazia do livro um objeto precioso, por outro lado, as experiências que surgiram, configuraram-se ou reconfiguraram-se na expectativa de atender as diversas demandas de produção do livro impresso ${ }^{552}$, potencializando padrões e técnicas originárias ou aperfeiçoadas justamente para atender tais demandas, de tal forma que o campo da ilustração contribuiu, e muito, para o fomento da gravura.

(...) Criam-se técnicas de reprodução iconográfica adequadas ao livro impresso, como a xilogravura (de existência anterior à tipografia mas que sofreu adaptação a esse veículo), o talhodoce, a litografia e, por último, a fotografia. É claro que cada uma dessas técnicas possui existência autônoma em relação ao livro, porém sua divulgação mais ampla sempre se deu através da página impressa (...). Do ponto de vista da editoração entende-se por gravura a imagem, fixada numa superfície (prancha de madeira, placa de metal, bloco de pedra ou chapa fotossensível) capaz de reproduzir-se na impressão. Daí se nomearem indistintamente, em português e outras línguas, quando coincide se publicarem ilustrações com os diversos processos acima mencionados, "prancha" ou "gravura" $"$ ".

Ainda no final do século XV, a gravura em relevo, representada então pela xilografia, alcança sua máxima expressão com a obra $O$ Apocalipse de Albrecht Dürer, que reúne um conjunto de 15 grandes xilogravuras consideradas marcantes na história das artes gráficas. Outros artistas seus contemporâneos Lucas Cranach, Hans Burgkmair, Urs Graf, Hans Lützelburger, Hans Holbein ilustraram diversos livros que se destacaram pela perfeição alcançada com tal técnica $^{554}$.

Enquanto a xilografia alcançava seu apogeu, surgiu no horizonte uma nova técnica de gravura sobre placas de metal - a gravura a entalhe. Diferente da gravura em relevo, na qual se escava a madeira para formar o desenho, a nova técnica consiste em gravar o desenho diretamente sobre a superfície por meio de

\footnotetext{
553 ARAÚJO, op. cit. (2008, p 455-456)

${ }^{554}$ Ibid. (p 462)
} 
um instrumento - buril ou estilete - ou por meio de processos químicos - águaforte e suas variantes ${ }^{555}$. A diferença fundamental entre a gravura a relevo e a gravura a entalhe consiste no que fica impresso no papel - o relevo ou o entalhe $^{556}$. A ideia de "desenhar" no metal utilizando instrumentos afiados e resistentes é originária dos etruscos. Durante a Idade Média era relativamente comum ornamentar escudos, espadas, capacetes, armas, entre outros utensílios, com arabescos e figuras, com o propósito de decorá-los ${ }^{557}$. Acontece que durante o século XV, quando o papel já era razoavelmente conhecido e distribuído na Europa, alguns ourives começaram a entintar suas gravações e imprimi-las no papel para acompanhar com maior precisão o estado do trabalho ${ }^{558}$. Naturalmente essas experiências, somadas ao campo que foi se abrindo frente à demanda de ilustrar os livros impressos, serviram de fomento a essa nova técnica de gravura.

Inicialmente, devido a dificuldades técnicas produzidas pela má qualidade das placas de metal que apresentavam superfícies irregulares e de espessura variável, poucos livros foram ilustrados com a nova técnica; entretanto, com a invenção da laminagem em meados do século XVI, foi possível a produção de placas finas de superfície regular apropriada para a reprodução do livro impresso. Com isso, a gravura a entalhe, sobretudo o talho-doce, dominou o campo da ilustração do livro por cerca de dois séculos ${ }^{559}$.

A "Breve História del Grabado de Metal", apresentada pelo Museu de Belas- Artes de Caracas, aponta como registro mais antigo de gravura em metal a estampa "La Flagelación", datada de 1446, anônima, motivo pelo qual seu autor ficou conhecido como o "Mestre de $1446 " 560$. Naquela época, era comum não assinar as obras ou, quando muito, assinava-se com duas pequenas iniciais, de modo que os primeiros gravadores eram conhecidos pelos seus monogramas ou

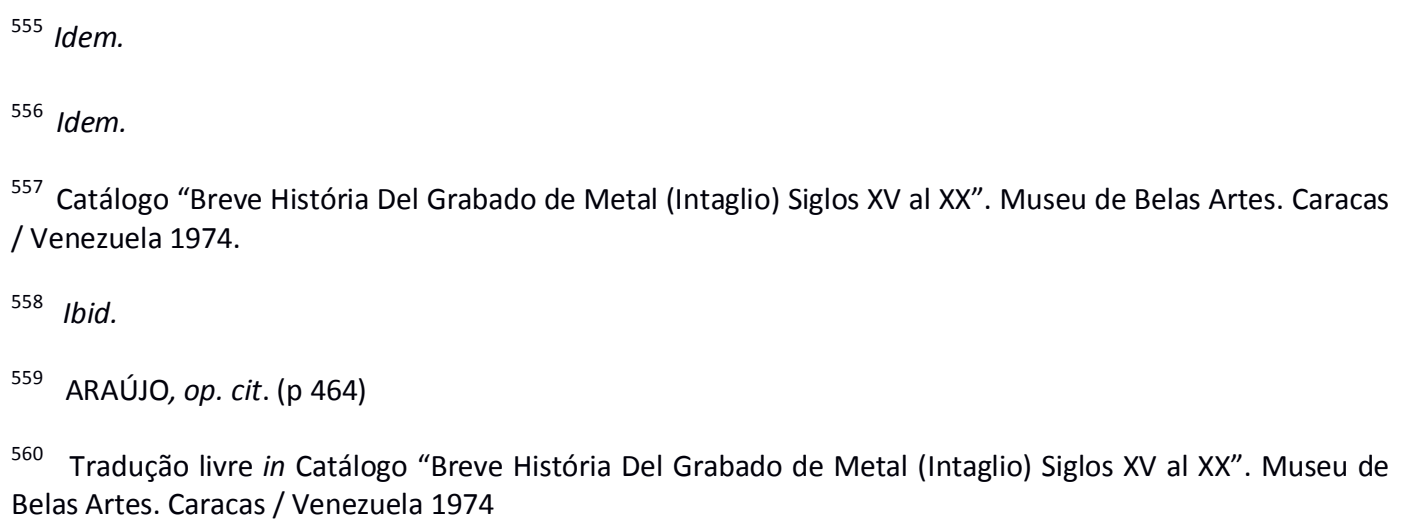


pelos temas com que trabalhavam frequentemente; por exemplo, "el Maestro de las Banderolas, el Maestro del Jardín del Amor, el Maestro F.V.B ${ }^{561 ~ ", . ~}$

A partir de 1600, a gravura ganha autonomia, e muitos artistas que foram também gravadores e haviam produzido gravuras para ilustrar livros passam a vender suas obras reproduzidas como estampas. Dentre eles, Dürer, Rafael, Rembrandt, Goya, William Black e Delacroix são exemplos importantes de artistas gravadores.

Desde as suas origens, a gravura foi usada para reproduzir e multiplicar a imagem de pinturas, afrescos, esculturas, tornando-se ainda importante instrumento de divulgação do trabalho de artistas, na medida em que ampliava o alcance de suas obras ${ }^{562}$.

Com Dürer, a ilustração ganha ação dramática e aproxima-se do ilusionismo visual da pintura ${ }^{563}$. Rembrandt, além de grande expoente dessa modalidade de gravura, marcou a história dessa arte com inúmeras técnicas alternativas que desenvolveu ao longo do processo de gravação e impressão ${ }^{564}$. Goya teve uma abordagem que extrapolou "em muito o simples desejo de divulgar uma obra criada independentemente", chegando a imprimir 300 conjuntos dos Caprichos, o que equivale ao inacreditável número de 2.400 impressões em uma época em que as mesmas sequer eram numeradas ${ }^{565}$.

William Blake é caso singular na história do livro, e merece destaque. O poeta inglês, necessitando exprimir-se através da integração absoluta entre o texto e a imagem ${ }^{566}$, ilustrava e reproduzia ele mesmo seus escritos, que, caracterizados pelo estilo do horror vacui medieval, tinham um completo preenchimento da mancha gráfica - ou da página toda - com ornamentos marginais e intratextuais, coloridos a mão, exemplar por exemplar ${ }^{567}$. Talvez tenha sido o primeiro artista a

\footnotetext{
561 Idem.

${ }^{562}$ CARDOSO, op. cit. (2008, p 19)

563 ARAÚJO, op. cit. (2008, p. 462)

${ }^{564}$ CARDOSO, op. cit. (2008, p 21)

565 Idem.

566 ARAÚJO, op. cit. (2008, p. 470)

567 Idem.
} 
realizar o processo todo, combinando a arte dos antigos iluminadores com as vantagens técnicas da reprodução mecânica em textos de própria autoria. $\mathrm{O}$ artista é apontado por vários pesquisadores como o maior artista da xilogravura de topo, técnica que se desenvolveu no século XIX, na qual as fibras da árvore não interferem na gravação. "Enquanto na gravura em madeira convencional 'ao fio', as tábuas de madeira são cortadas no sentido longitudinal da árvore, na xilogravura "de topo" as árvores são cortadas no sentido ortogonal ao comprimento do tronco ${ }^{568}$ ". Com isso o gravador consegue, de acordo com o enorme domínio técnico exigido, imagens muito mais complexas.

A técnica da xilografia de topo diferenciou-se por ter possibilitando a impressão simultânea de imagem e texto, agilizando com isso todo o processo. Grandes clássicos da literatura foram ilustrados por tal técnica, dentre os quais citamos Alice no país das maravilhas, de Lewis Carroll, publicado em 1860 e ilustrado por Tenniel, e A Divina Comédia, de Dante, ilustrado a partir de 1885 por Gustave Doré e colaboradores ${ }^{569}$. Aliás, Doré ilustrou mais de dez mil imagens para autores como Shakespeare, Poe, Cervantes, Balzac, entre outros ${ }^{570}$.

Enquanto tais técnicas desenvolviam-se à perfeição disputando a preferência do leitor e da cadeia produtiva do livro, "inventou-se no final da última década do século XVIII mais um processo de gravação e reprodução de imagens". Segundo se conta, Alois Senefelder (1771-1834), ator e escritor, com o propósito de encontrar uma forma de reprodução gráfica simples e barata para imprimir suas próprias peças teatrais, visto que nenhuma editora dispunha-se a fazê-lo, terminou por revolucionar a ilustração e, mais tarde, as artes gráficas em geral com a invenção do novo processo que se deu entre 1796 e $1798^{571}$. Conforme a descrição de Emanuel Araújo, a gravura em plano ou litografia (do grego lithos, 'pedra', e grápho, 'gravar, escrever, desenhar') baseia-se na repulsão

\footnotetext{
568 Ibid. (p. 22)

569 Ibid. (p 23)

570 ARAÚJO, op. cit. (2008, p 473)

571 Idem.
} 
recíproca entre uma substância gordurosa e a água sobre um tipo especial de pedra encontrada então na Baviera ${ }^{572}$.

Consistindo de um desenho com lápis de cera sobre uma pedra, o novo meio permitiu pela primeira vez produzir imagens coloridas a custo baixo. O crescimento da figura impressa foi a mudança mais profunda da comunicação visual de todo aquele período, pois permitia, como nunca, que as imagens ficassem disponíveis para difusão. $\mathrm{O}$ processo rapidamente envolveu os principais artistas do Renascimento, como Botticelli, que criou uma série de ilustrações em xilogravuras para a Divina Comédia, de Dante. Os impressos eram relativamente baratos de se fazer e transportar, permitindo que o trabalho dos artistas alcançasse rapidamente um número elevado de pessoas ${ }^{573}$.

A litografia revelou-se uma forma de reprodução de imagens técnica e economicamente eficiente devido às seguintes especificidades: afinidade quase direta com o desenho; fidelidade na reprodução de pinturas e rapidez de impressão. Com isso desenvolveram-se e difundiram-se rapidamente inúmeras variações - como a reprodução litográfica sobre lâminas metálicas, que eram mais fáceis de manusear -, que, junto a outras tecnologias, engendraram nas quatro décadas seguintes a indústria gráfica propriamente dita ${ }^{574}$.

No lastro da litografia, veio a fotografia - gravura química por meio da luz - que vinha sendo gestada a partir de experiências óticas há alguns séculos ${ }^{575}$. Emanuel Araújo enfatiza que a fotografia, assim como a litografia, tinha em vista desde o início "justamente a economia, rapidez e a fidelidade de impressão de quaisquer imagens ${ }^{576,}$.

A partir da litografia e da fotografia, aliás, introduziu-se a noção de fac-símile na ilustração, que, no sentido mais amplo, pretende reproduzir a imagem de forma absolutamente fiel, sem a intermediação dita 'interpretativa' (ou subjetiva) do desenhista. Assim, aquilo que se considerava peça única (texto manuscrito, pintura, desenho...) passou a ser multiplicado às centenas ou milhares praticamente em sua feição primitiva; reproduzida sob processo fotomecânico, obtinha-se, na prática,

\footnotetext{
${ }^{572}$ ARAÚJO, op. cit. (2008, p 473)

573 BRIGGS e BURKE, op. cit. (2008, p 47)

574 CARDOSO, op. cit. (2004, p 24)

575 Ibid. (p 25)

576 ARAúJO, op. cit. (2008, p 480)
} 
um verdadeiro neomansucrito ou neo-original sem a tradução tipográfica ${ }^{577}$.

O advento da litografia e da fotografia resultou em um dos mais bemsucedidos processos de impressão do século XX - o offset - que utiliza chapas finas de alumínio trabalhadas fotograficamente ${ }^{578}$.

Cumpre sublinhar que se, por um lado, a evolução dos processos de impressão da imagem conquistavam cada vez mais espaço na página, por outro perdia-se pouco a pouco a originalidade ${ }^{579}$. Essa massificação da imagem suscitou questionamentos e reações tanto no âmbito das artes gráficas, como entre escritores e poetas, que terminaram por convergir e instaurar o campo do livro de artista.

\footnotetext{
577 Ibid. (p 474)

578 Ibid. (p 475)

579 Ibid. (p 485)
} 


\subsection{O livre d'art, livre d'peintre ou livre d'artiste}

Acontece que na última década do século XIX, as chamadas gráficas particulares - private press $^{580}$ - em oposição às gráficas comerciais, reagiram com vigor contra a uniformização massificada do livro ${ }^{581}$. No lastro da tradição editorial de Aldo Manuzio ${ }^{582}$ - que primava por uma produção extremamente qualificada e cuidada, impactando de forma decisiva na apresentação do livro ${ }^{583}$-, tais casas editoriais buscavam atender em cada um de seus projetos aos seguintes quesitos: 1) composição harmoniosa entre a tipologia, ilustração e diagramação da página; 2) adequação da técnica de impressão com os melhores papéis e tintas do mercado; 3) retorno a técnicas artesanais na execução de alguns processos ${ }^{584}$ e, 4) a colaboração de artistas para ilustrar livros com originalidade e extrair o máximo do potencial de relação e diálogo entre texto e imagem ${ }^{585}$.

O exemplo mais bem-sucedido desse modelo, de acordo com Emanuel Araújo $^{586}$, foi a Kelmscott Press, pois as diretrizes, posicionamento e questionamento de seu fundador causaram repercussões profundas não apenas no âmbito das artes gráficas, mas também no campo da arte. Foi fundada em 1891 por William Morris, poeta, escritor, tradutor, editor, designer e membro fundador

\footnotetext{
580 A expressão vem do inglês e designa uma gráfica particular cujo interesse não seja estritamente comercial. Esse modelo de negócio já existia em meados do século XV, e subsistiu ao longo da evolução do livro impresso, revigorando-se no final no século XIX frente a massificação do livro. Vale ressaltar o ressurgimento destes conceitos que vem fomentando há cerca de duas décadas um movimento parecido representando pelo estabelecimento das editoras independentes, cujo posicionamento confronta com novos modelos de negócios, técnicas semi-artesanais com baixas tiragens, e, espaço a bibliodiversidade, o modelo tradicional de edição e publicação de livros estabelecido e condicionado estritamente pelo interesse comercial.

581 ARAÚJO, op. cit. (2008, p.462)

582 Foi o primeiro editor do seu tempo (século XVI) a compreender a enorme importância do livro, suas partes, sem perder seu caráter artístico. Entre as várias de suas contribuições para as artes do livro estão a invenção da letra cursiva, o formato de bolso, o livro ilustrado, a ideia da página dupla como unidade formal, a capa de couro sobre papelão, as coleções temáticas, os catálogos, conselhos editoriais etc.. Graças a sua simultânea condição de editor, tipógrafo e livreiro, resume em si mesmo a história do livro. SATUÉ, Eric. Aldo Manuzio - Editor. Tipográfo. Livreiro. Rio de Janeiro: Ateliê Editorial, 2005.

583 ARAÚJO, op. cit. (2008, pp 485-486)

584 Ibid. (p 486)

585 Ibid. (pp 486-490)

${ }^{586}$ Idem.
} 
do Arts and Crafts - movimento que buscou a valorização, instrução e renovação do artesanato, da arte tipográfica e do design ${ }^{587}$. Morris acreditava no artesanato criativo como alternativa viável frente à indústria capitalista e, consoante com essa visão, defendeu o conceito do artesão-artista ${ }^{588}$, segundo o qual o artista devia ensinar e fazer coisas simultaneamente naturais e espirituais, úteis e belas, e o operário deveria desenvolver um valor estético (ético-cognitivo) ao trabalho desqualificado pela indústria, tornando-se assim um artista que faz de seus afazeres cotidianos sua obra de arte ${ }^{589}$.

\begin{abstract}
"Quero falar daquele lado da arte que deveria ser sentido e executado pelo simples operário em seu trabalho cotidiano, e que com razão chama-se arte popular. Essa arte não existe mais, destruída pelo comercialismo. Mas ela viveu e floresceu desde o início da luta entre o homem e a natureza até o surgimento do sistema capitalista. Enquanto durou, tudo o que o homem fazia era ornamentado pelo homem, assim como tudo que faz a natureza é ornamentado pela natureza" ${ }^{590}$.
\end{abstract}

Para $\operatorname{Argan}^{591}$, Morris - um homem de ação e ideias políticas claras, além de socialista militante e polemista -, influenciado pelo pensamento de Ruskin e pelas ideias de Marx, alterou substancialmente todo o problema da arte, pois a corrente morrisiana, ao defender "a eliminação da especificidade das artes, a inserção direta da experiência estética na práxis da produção econômica e da vida social, e a individuação de um estilo artístico capaz de se tornar um estilo de vida ${ }^{592,}$, originou o modern style, conceito que se difundiu sob os seguintes nomes em todos os níveis sociais na Europa e nos Estados Unidos: Art Nouveau na França; Jungendstil na Europa Central e Liberty na Itália ${ }^{593}$.

\footnotetext{
587 SPINELLI, Daniela. In “William Morris e sua crítica moral do sistema produtivo capitalista” publicado no MORUS - Utopia e Renascimento, 12, 2017. Doutora em Teoria e História Literária pela Universidade Estadual de Campinas - Unicamp. É pesquisadora colaboradora do departamento de Pós-Graduação em História da Universidade Federal de São Paulo.

588 Idem.

589 ARGAN, Giulio Carlo. Arte Moderna. Editora Companhia das Letras, São Paulo, 2ªedição, 1992. (Morris apud Argan pp 179-182)

590 Idem.

591 Idem.

592 Idem.

593 Idem.
} 
Com base nessas mesmas premissas que orientaram seu posicionamento frente à arte e à arquitetura, Morris, admirador da caligrafia gótica, reabilitou o livro como produto de um processo artesanal. Acontece que seus projetos editoriais renovaram a linguagem visual da página, fomentando inclusive um novo mercado de livros de $\operatorname{arte}^{594}$. A intenção da Kelmscott Press era resgatar a beleza das antigas publicações do século XV oferecendo ao público leitor obras prazerosas de olhar e segurar. Morris reconhece o valor da máquina de Gutenberg principalmente pela eficiência com que difundiu conteúdos culturais entre as massas, mas crítica a vulgarização de tais conteúdos pela estrutura de produção capitalista, que aceleravam a impressão dos livros grosseiros visando garantir a maior margem de lucro sob o menor custo.

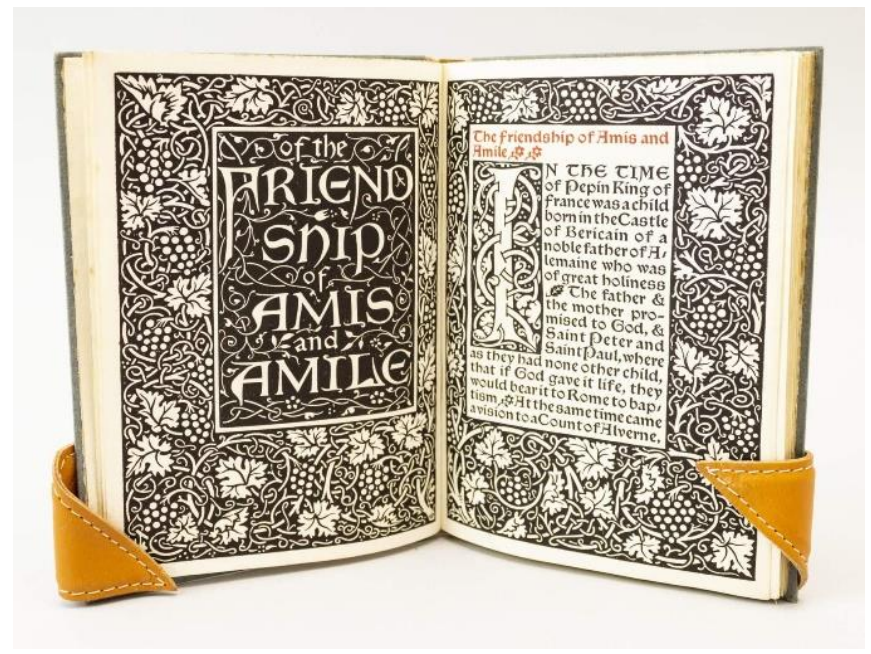

Figura 284: Página dupla de Of The Friendship Of Amis And Amile - Kelmscott Press,

A Kelmscott Press abriu o campo a outras gráficas particulares inspiradas pelo propósito de resgatar a arte do livro. Os exemplos que se seguem, escolhidos devido à relevância do trabalho e com data de fundação circunscrita ao final do século XIX e início do século XX, ilustram as características formais, o modelo processual e o perfil dos atores envolvidos - escritores, artistas e editores -, nessa missão que se mostrou precursora do que se convencionou chamar posteriormente de livro de artista. 
Ashendene Press (1894-1935), inglesa, contou com a colaboração de alguns artistas, dentre os quais destacamos Graily Hewitt - que junto a Edward Johnston renovou a caligrafia e as iluminuras no século XX - e Eric Gill, um dos maiores tipógrafos do século XX, dedicado também a escultura, ilustração e gravura ${ }^{595}$.
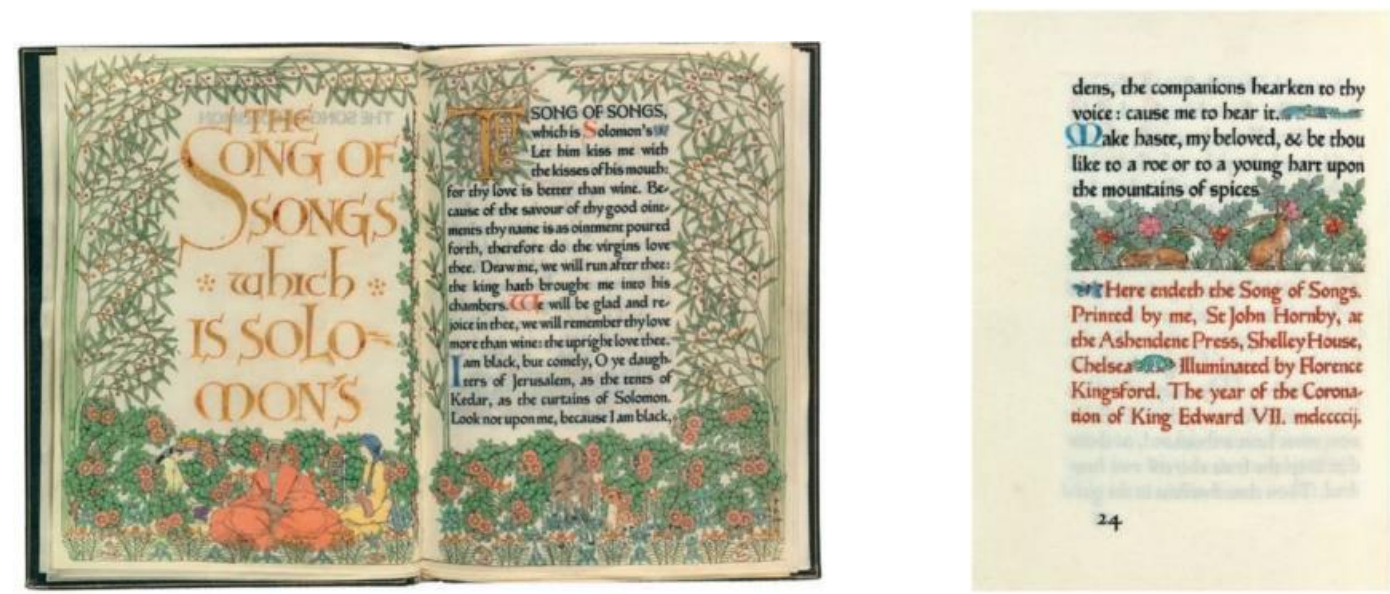

Figura 295: Páginas do livro Song of Solomon - Eragny Press

Eragny Press (1894-1903), inglesa, fundada pelo pintor, designer e gravurista Lucien Pissaro e sua esposa Esther Levi Bensusan; especializada em livros infantis, e conhecida sobretudo por suas extraordinárias gravuras em xilogravura muitas vezes impressas em várias cores usando diferentes blocos de madeira ${ }^{596}$.

\footnotetext{
595 ARAÚJO, op. cit. (2008, p 486)

596 ARAÚJO, op. cit. (2008, p 486)
} 


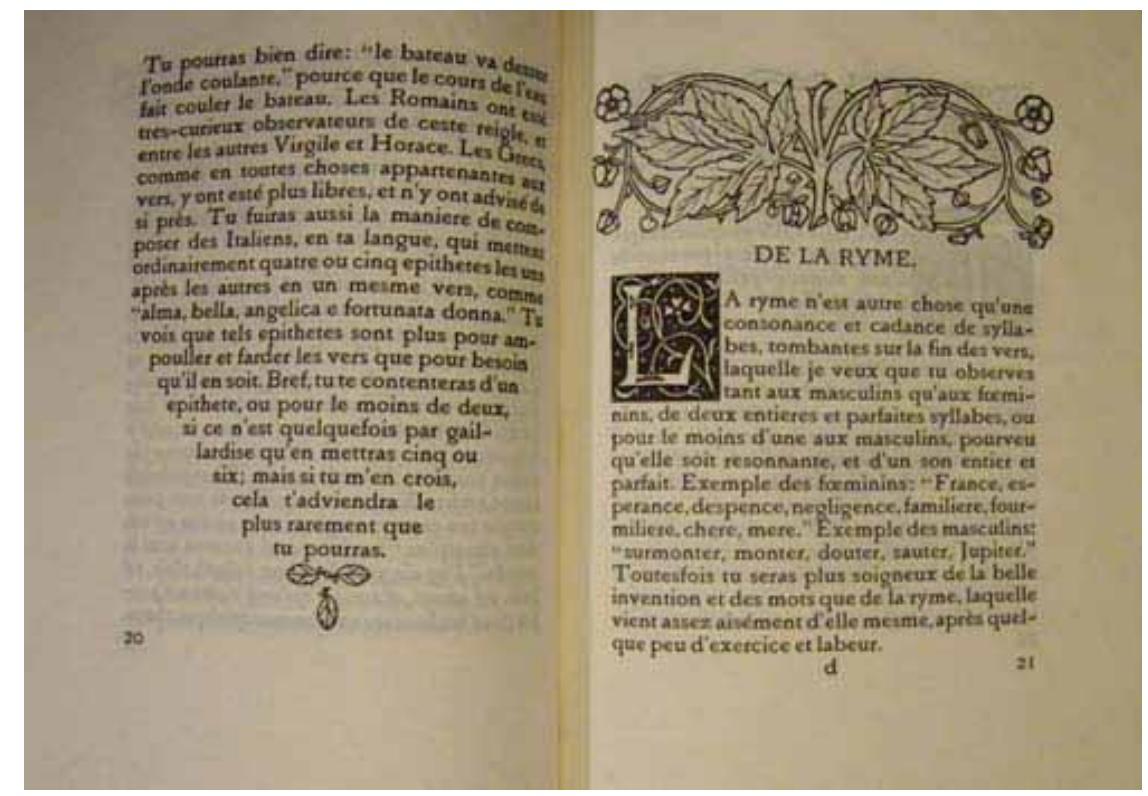

Figura 306: Página dupla de Abregé de L’art Poetique Française - Eragny Press

A Doves Press (1900-1917), inglesa, de Thomas James Cobden-

Sanderson e Emery Walker. A Doves Press não utilizou ornamentos e ilustrações, entretanto, explorou ao máximo a composição entre o desenho dos tipos, as capitulares desenhadas por Edward Johnston e a diagramação ${ }^{597}$. A estética desenvolvida em seus projetos gráficos primava pela excelência de impressão e elegância. A Dove Press Bible, por exemplo, considerada a melhor edição da casa editorial é reconhecida e elogiada pela clareza de seu design e tipografia destacada pelas capitulares vermelhas desenhadas à mão ${ }^{598}$.

\footnotetext{
${ }^{597}$ ARAÚJO, op. cit. (2008, p.486)

598 https://library.wustl.edu/55509-2/ Acesso 04/08/2019 às 23:30
} 


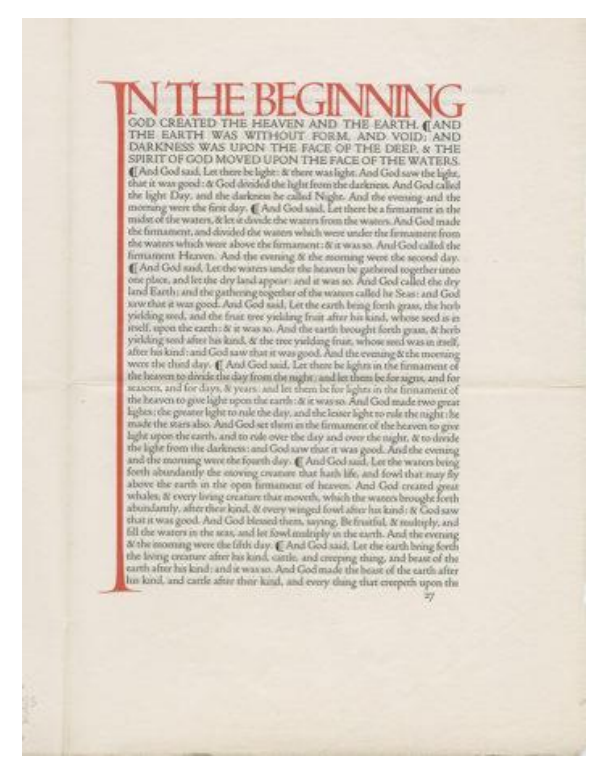

Figura 317: Página da Dove’s Bible - Doves Press Press

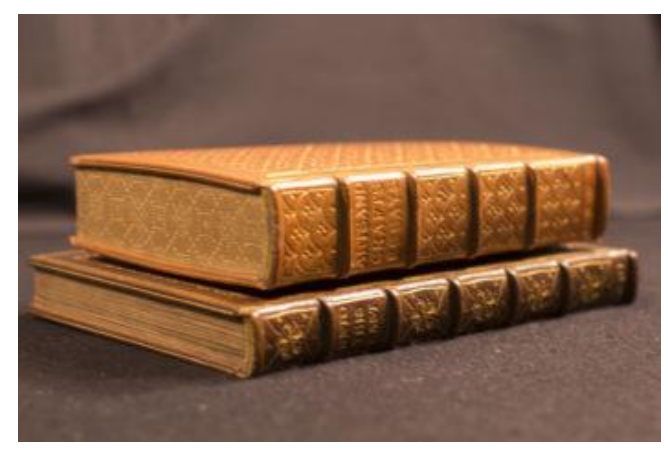

Figura 328: Encadernação da Doves

A partir desse movimento das gráficas particulares da Inglaterra, que teve imediata repercussão na Europa e nos EUA, a iconografia sofreu transformações radicais. Muitos ilustradores, até a década de 1910, influenciados ou não por Morris, atinham-se às técnicas tradicionais da gravura em relevo (xilogravura) e a entalhe com buril (talho-doce) ou com processos químicos (água-forte). Esses trabalhos foram iguais e, às vezes, superiores aos das gráficas particulares inglesas, o que levou a ilustração não só a tornar-se mais rica, como até a ganhar maior autonomia em relação ao texto ${ }^{599}$.

Contemporaneamente à nova perspectiva, grandes pintores do modernismo - Toulouse-Lautrec, Matisse, Miró, Chagall, Rouault, Max Ernest, Picasso, entre tantos outros -, por iniciativa, sobretudo de editores franceses, entre os quais se destaca o também marchand Ambroise Vollard, passaram a trabalhar no livro utilizando as mais variadas técnicas. "Inaugurava-se o livre d'art ou o livre d'artist, em que a imagem ou se bastava a si própria ou concorria em pé de igualdade com o texto ${ }^{600,}$.

\footnotetext{
599 ARAÚJO, op. cit. (2008, p 490)

600 Idem.
} 
Riva Castleman como Peyré, analisou através de uma amostra de 140 exemplares, um século de livros de artistas em seu A century of artists books ${ }^{601}$ publicado aliás, alguns anos antes que Peinture et Poésie - le dialogue par le livre 1874-2000 -, e considera, junto a colaboração de grandes nomes do modernismo, que teriam se dedicado a "iluminar" poemas, literatura clássica ou seus próprios escritos em edições limitadas e luxuosas destinadas a colecionadores, o início do século XX como marco inicial do livro ilustrado como forma de arte. Castleman contempla todas as vertentes que se desenharam, seguindo caminhos os mais diversos - da apropriação com cunho estético-político surgido através das mãos de artistas como Kasimir Malevich, Marcel Duchamp e Edward Ruscha, às mais recentes perspectivas contemporâneas oriundas da consideração do livro como lugar e espaço de excelência para criação artística ${ }^{602}$.

A sensibilidade de sua visada inclusiva e generosa é inestimável para compreensão dos diversos contextos nos quais se deu, após a germinação do campo, a apropriação e reinvenção do livro de artista, que a cada vez surpreende em sua plasticidade infinita. Aliás, cabe ressaltar, além da abrangência de sua curadoria, a coerência com que valorizou sobretudo, a primazia que o campo oferece no que tange busca e experimentação - tanto dos materiais e técnicas quanto ao estudar-se a si mesmo na criação -, priorizando assim: livros feitos a mão; os primeiros exemplos do trabalho do artista; e avanços estilísticos ou teóricos que contribuíram para a explanação da arte do livro, em detrimento de outros tantos bem conhecidos porém com menor pertinência a questão ${ }^{603}$.

Sua abordagem apresenta ainda um lado da história que tem sido ignorado, tanto pela desinformação quanto pela desconsideração: o reconhecimento da complexidade de se produzir livros, e, por conseguinte, o papel fundamental e indispensável dos variados colaboradores sem os quais tal campo não existiria - os editores, impressores, designers, ilustradores, autores, enfim, todos que de alguma forma compõe a cadeia criativa do livro. Devido a tal reconhecimento, Castleman

\footnotetext{
${ }^{601}$ CASTLEMAN, Riva. A century of artists books. New York: The Museum of Modern Art: Distributed by H.N. Abrams, 1994. Este catálogo acompanhou a exposição de mesmo nome considerada a maior e mais completa da categoria. Referência para pesquisadores e deleite para bibliófilos.

602 Idem.

${ }^{603}$ Ibid. (p 13)
} 
traz à tona e valoriza estas relações, contemplando por isso com especial atenção aos artistas que conseguiram gerir todo o processo de criação, dado os fatores e manejo de materiais que naturalmente ficam fora do controle ou do alcance do $\operatorname{artista~}^{604}$. A exposição foi dedicada a Monroe Wheeler, organizador da primeira e singular exposição realizada sobre livros de artistas em 1939 no MoMA, personalidade a quem, ela mesma, o Moma, e todos os amantes de livros são devedores. Por sua vez, Monroe Wheeler dedicou seu trabalho a Ambroise Vollard, por reconhecê-lo como o grande pai do livro de artista e do moderno livro ilustrado, fato que, Castleman faz questão de nos lembrar, pois tem sido esquecido ou minimizado na maioria das publicações sobre o assunto ${ }^{605}$.

\footnotetext{
${ }^{604}$ Ibid. (p 18)

${ }^{605}$ Idem
} 


\subsection{0 campo do livro de artista e o potencial plástico do livro}

Há bons livros, livros quaisquer e livros ruins. Entre os bons, há os que são honestos, inspiradores, emocionantes, proféticos, edificantes. Mas na minha língua há outra categoria, a dos livros-ha! Os livros- ha! são aqueles que determinam, na consciência do leitor, uma mudança profunda. Eles dilatam a sua sensibilidade de tal maneira que ele se põe a olhar os objetos mais familiares como se os observasse pela primeira vez. Os livros-ha! galvanizam. Atingem o centro nervoso do ser, $e$ o leitor recebe um choque quase físico. Um arrepio de excitação percorre-o da cabeça aos pés. Vernon Proxton ${ }^{606}$

A categoria dos livros-ha!, citada ao início deste capítulo poderia ser mais uma dentre as muitas designações que tentam dar conta de tal campo: livro de artista, livro-objeto, arte-livro, livro-poema, poema-livro, livro ilustrado, livroobra, livro-processo - e outras variantes que não param de surgir. Atualmente existe até mesmo livro de artista eletrônico (!). Ainda que o autor do texto tenha lançado mão de tal expressão para referenciar a apreensão da obra literária, fato incontestável é que tal texto está contido em um objeto, e, portanto, há recepção estética também à forma material de seu continente - a coisa livro. Silveira ${ }^{607}$, embora evidencie uma apreensão pessoal abrangente e superior ao senso comum, descreve muito bem tal relação:

O prazer da leitura é, para muitos, uma emoção que não consegue libertar-se do prazer de sentir o papel na mão ou o seu cheiro. Gosto de observar as ilustrações, de perceber a trama das retículas de impressão, de encontrar um desajuste nas cores: descobrir o magenta e o amarelo por detrás do vermelho. Gosto de contar os seus cadernos, ver como são costurados e quantas páginas há em cada um. E gosto de suas marcas de tempo: as páginas amareladas, manchas de uso, anotações nas margens, os nomes em esferográfica de seus donos. Tudo evidenciando que um livro é um objeto. Ele não é a obra literária. A obra literária é de escritores, pesquisadores, publicadores. O livro é de artistas, artesãos, editores. É de conformadores. ${ }^{608}$

\footnotetext{
${ }^{606}$ OUAKNIN, Marc-Alain. Epígrafe In Biblioterapia. São Paulo: Edições Loyola, 1996.

607 SILVEIRA, op. cit. (2008, p 13)

608 Idem.
} 
De fato, o livro é (também) um objeto. Uma obra literária em estado original, in natura ${ }^{609}$, não é um livro. Mesmo que o texto seja o primeiro elo na corrente que vai do leitor ao escritor, o livro, tradicionalmente, sempre foi e ainda é, hoje, fruto de um trabalho colaborativo entre as cadeias criativa, produtiva e mediadora. Ulisses Cárrion pontuou precisamente: “Um escritor, ao contrário da opinião popular, não escreve livros; um escritor escreve textos" ${ }^{\text {"610 }}$. No entanto, a partir de iniciativas como a do editor e marchand Ambroise Vollard, que, como vimos, em pareceria com artistas da avant garde participou da inauguraração do livre d'art ou o livre d'artist, ao apropriar-se do livro e incorporá-lo em seu fazer artístico, teórico ou prático. Por meio da plasticidade e singularidade dispostas na constituição da coisa em si, tal objeto passou a fazer parte, naturalmente, do repertório do artista, com o que configura-se "A nova arte de fazer livros", assim designada por Cárrion, que nos apresenta os primeiros pressupostos norteadores:

\begin{abstract}
Um livro pode ser o recipiente acidental de um texto, cuja estrutura é irrelevante para o livro: estes são os livros das livrarias e das bibliotecas. Um livro também pode existir como uma forma autônoma e independente, incluindo talvez um texto que seja parte integrante e que enfatize essa forma: aqui começa a nova arte de fazer livros. Na velha arte o escritor não se julga responsável pelo livro. Ele escreve o texto. O resto é feito pelos empregados, os artesãos, os trabalhadores, os outros. Na nova arte o escritor assume a responsabilidade pelo processo inteiro. $\mathrm{Na}$ velha arte o escritor escreve textos, na nova arte, o escritor faz livros ${ }^{611}$.
\end{abstract}

Em primeira instância, o texto de Cárrion refere-se aos escritores, não com intenções exclusivistas, certamente, mas muito provavelmente porque assim como o autor era também escritor, o potencial de diálogo entre imagem e texto era o grande atrativo. E o livro naquele momento pertencia, sobretudo, ao universo literário. A razão de ser do livro - conter e portar a obra literária -, vigente

\footnotetext{
${ }^{609}$ Termo utilizado no meio editorial para designar o texto original, seja manuscrito ou digital, que não passou por nenhum processo de edição.

${ }^{610}$ CÁRRION, op. cit. (2011, p 7)

${ }^{611}$ ARAÚJO, op. cit. (p 14, 2011)
} 
naquele período, desloca-se, devagar e irreversivelmente, para novos territórios, novos sujeitos, novos sentidos.

Acontece que o livro como objeto continente e portador não possui a natureza de um objeto passivo que, ao conter qualquer coisa, esvazia-se e torna-se simplesmente o objeto vazio. Um copo vazio, por exemplo, ao preencher-se e esvaziar-se de água, segue sendo um copo. No caso do livro, não, o que ali se inscreve - em qualquer linguagem - passa a fazer parte indissociável da coisa, seja essa linguagem literária, acadêmica, intelectual, conceitual, poética ou artística. Esse é o atributo que o faz único na qualidade de portar a obra, transformar-se na obra.

Possui a singularidade, enquanto objeto, de se transubstanciar na fala de seu autor, mantendo vivo seu imaginário, pensamentos, sentimentos, percepções, memórias, enfim, toda a sua história intelectual e também a sua arte. Objeto raro que traz em si o potencial de plasmar e portar o mais essencial no homem, que, no entanto, the é imaterial. Essa é sua natureza, sua ontologia. Acredito que seja o objeto que mais represente o homem, pela sua "personificação", pelo simbolismo de sua constituição formal, e, ainda, pela conotação de "verdade612" que traz. Na cultura ocidental, o que está escrito em um livro tem a conotação de verdade. $\mathrm{Na}$ tradição do nosso conhecimento, a verdade é posta e inscrita nos livros. A poiesis, imaterial, para os antigos gregos estava na palavra do poeta ou no canto do aedo; para nós ocidentais essa poiesis é inscrita e materializada na coisa livro. É como se a coisa livro possuísse uma alma. Stéphane Mallarmé expressou-o assim: "Le livre, instrument spirituel", evidenciando a convivência, no livro, do físico (pelo “instrumento") com o afetivo (pelo "espiritual”) ${ }^{613}$. Provavelmente um dos fatores preponderantes para a abordagem ao livro como campo poético transite justamente neste âmbito: das relações intrínsecas entre as especificidades de seus polos opostos - espaço-tempo, conteúdo-forma, corpo-alma, presença-ausência, aberto-fechado, matéria-espírito, frente-verso etc. - e sua integridade. Tais polaridades inerentes em sua constituição insinuam de alguma forma os dualismos do homem e sua individualidade.

\footnotetext{
612 Verdade do indivíduo, no sentido de sua memória, imaginação, pensamentos e sonhos, conhecimento, enfim, sua autenticidade.

${ }^{613}$ SILVEIRA, op. cit. (Mallarmé apud Silveira 2008)
} 
Tal referência que poder-se-ia dizer, além de simbólica, afetiva, é o que subsiste de alguma forma - como metáfora, conceito, rastro, referência ou qualquer coisa assim - no livro-objeto ou livro escultórico, por exemplo, que são feitos a partir de apenas um elemento referente, como a página, a lombada ou o cabeceado. Eles situam-se nos limites do não-livro, e ainda assim percebe-se que cada uma dessas partes guarda a relação de ser do todo. O mesmo podemos constatar quando da inexistência da obra literária ou ainda na inexistência de qualquer texto ou sistema de signos. Continuam contendo o imaginário, o conceito, a forma, continuam sendo livros. Por meio dessa relação e da incrível plasticidade que o livro oferece, pode-se compreender as diversas variantes que se foram constituindo - livro-objeto, livro-obra, livro-processo, livro de artista etc. É nesse sentido que Silveira percebe nas gradações entre o livro ilustrado (que tem amplo trânsito entre os bibliófilos) e o livro-objeto (produto quase exclusivo das artes visuais), e nas diversas designações que os diferenciam, ferramentas para a compreensão da obra ${ }^{614}$. O referencial - conceitual e formal - seriam expressões das potencialidades contidas, percebidas e exploradas pelo artista ao se apropriar desse objeto poético e encantatório que acreditamos ser o mais significativo objeto cultural ocidental ${ }^{615}$ - o livro. Parece-nos então, "natural que o livro, um suporte preexistente e com regras, significados e tradições, enseje atitudes artísticas" em sua concepção e elaboração"616. A maioria dos movimentos artísticos do século XX de alguma forma tem um vínculo com o livro. O livro passou a ser apreendido como campo relacional na arte contemporânea para experimentação e registro do processo criativo do artista. O potencial do livro como objeto plástico, intermidiático e híbrido; as camadas de relação espaçotemporal que ele sugere; o campo de presença e encontro que instaura, a relação processual entre artista e obra, entre outras especificidades, fortaleceram seu vínculo com o artista, tornando-se assim campo de excelência para processos de criação, experimentações e liberdades poéticas. É preciso reconhecer que estamos diante de um campo preexistente, fronteiriço, híbrido, movediço, transdisciplinar

\footnotetext{
${ }^{614}$ Idem, (p 21)

${ }^{615}$ Idem, (p 21)

${ }^{616}$ Idem, (p 29)
} 
e atravessado por questões da arte moderna e contemporânea; portanto, naturalmente expandido. Sem tal perspectiva não se pode compreendê-lo. Dentre as formas que o livro adquiriu ao longo da história, acreditamos que o livro de artista, como registro do processo criativo ou como obra de arte, seja o que mais vem explorando todas as potencialidades (in)contidas nesse objeto-espaçotemporal.

Fechamos com Riva Castleman, que com poucas palavras e muita maestria, capta o essencial dessa arte que se faz possível no livro por meio do espaço de criação oferecido para que imagem e texto possam se encontrar e dialogar.

Uma arte que não se limita a ilustrar palavras, mas interpreta, ilumina, soma à nossa sabedoria algo além do texto, ou provoca, desafia o próprio texto. ${ }^{617}$ (...) São livros-arte em que texto e imagem integram a visão do artista, em páginas que se sucedem tratadas como sustento da composição artística. É uma forma de composição que modifica a leitura, faz com que ela deixe de seguir um rio de pensamentos postos em palavras, para dinamizar-se entre imagens e letras que jogam umas com as outras ${ }^{618}$.

\footnotetext{
${ }^{617}$ Grifos nossos.

${ }^{618}$ ARAÚJO, op. cit. (Castleman apud Araújo, 2008, p 490)
} 


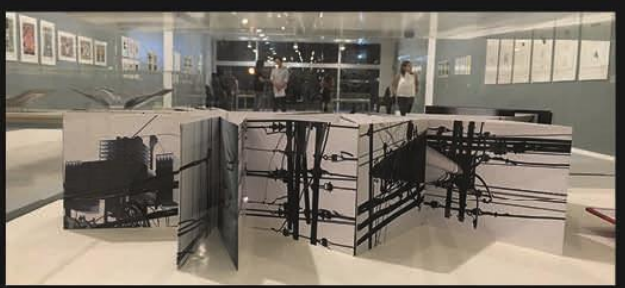

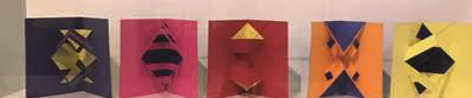

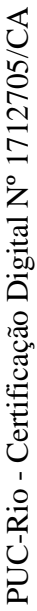
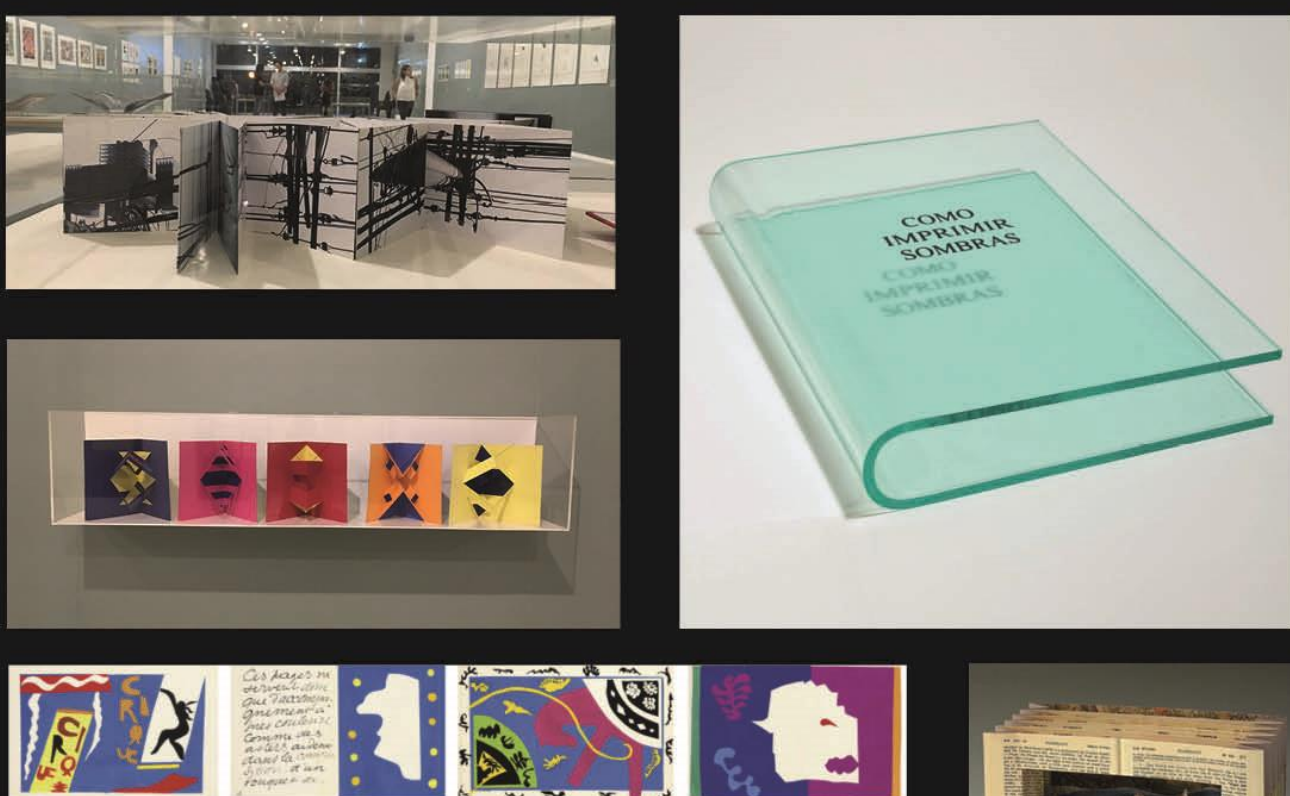

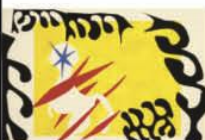
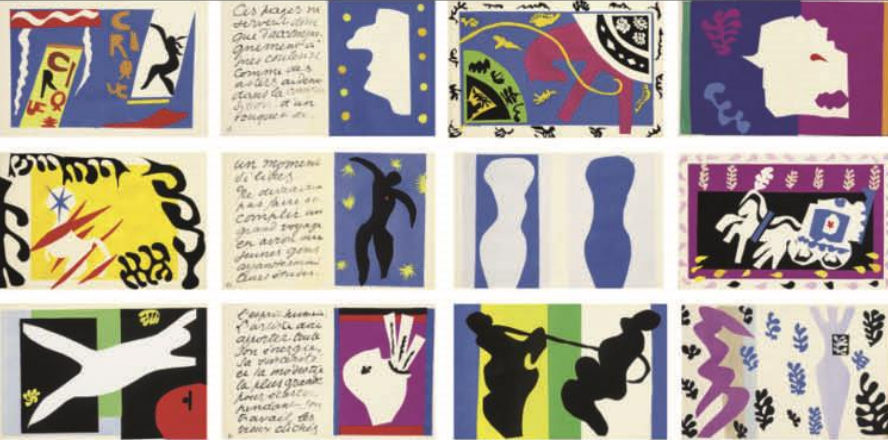

क $\frac{8}{8}$ है

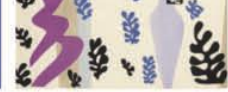

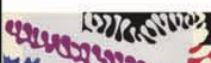

mecoutatis, nower

स

cossoswrs है

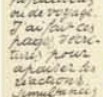
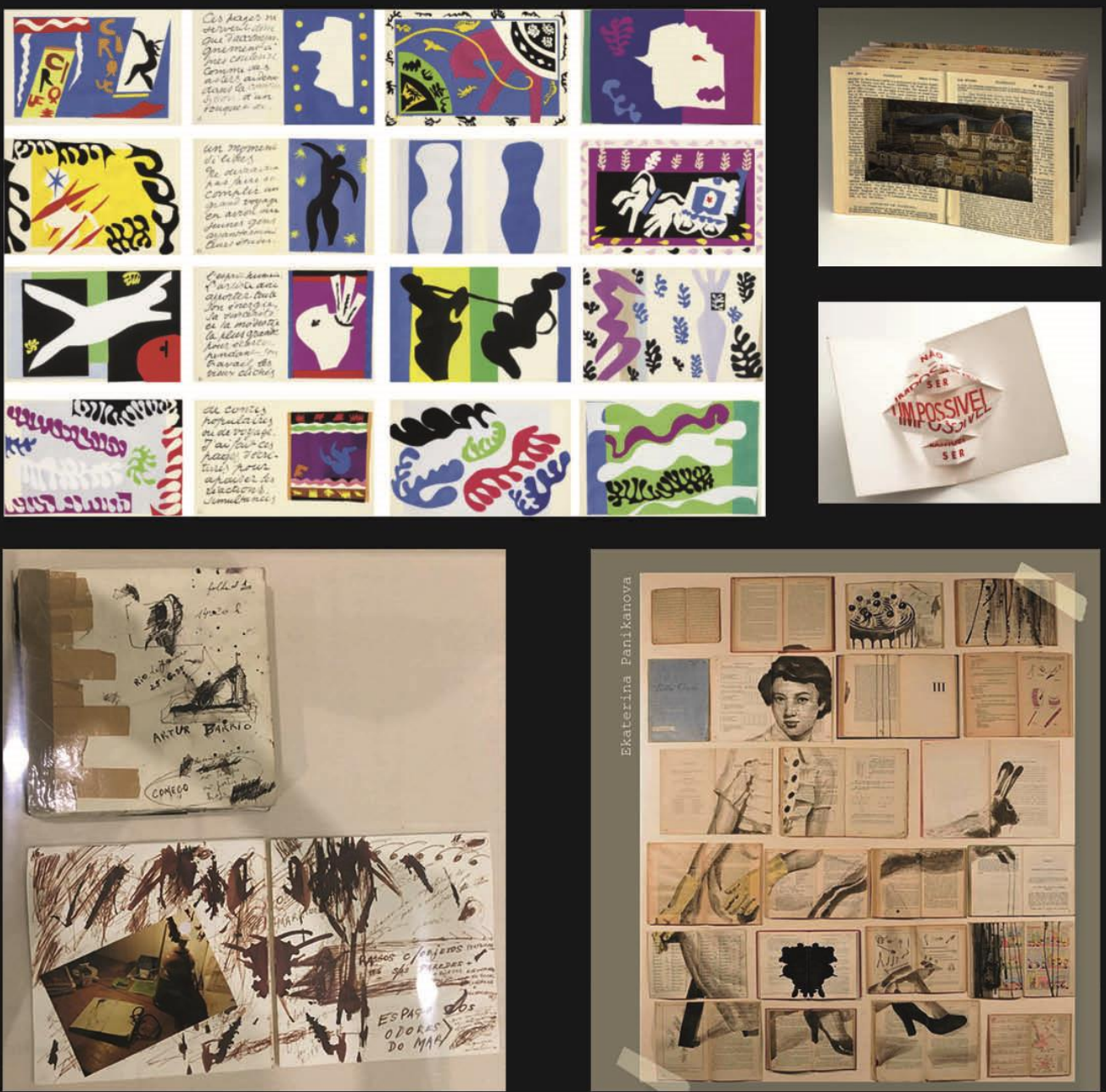

Figura 339: Amostra de Livros de Artista 


\section{CONSIDERAÇÕES FINAIS}

O objetivo que está por trás de toda a obra de arte verdadeira é a conquista de um estado de ser, um estado de alta performance, um momento de existência acima do ordinário. Em tais momentos, a atividade é inevitável, não importa se feita com pincel, pena, cinzel, ou a língua, e seu resultado não é senão um subproduto do estado, um vestígio, um rastro do estado ${ }^{619}$.

A arte designa uma dessas coisas que não cabem em si. Transborda pelo excesso de sentido e realidade. Sua origem e história estão intrinsecamente entrelaçadas à nossa mais genuína humanidade. Como objeto, a arte tem sido um precioso testemunho histórico, através do qual o homem consegue estender seu olhar a tempos e culturas que lhe são imemoriais. Como fenômeno, a arte atravessou a história sob diversos significados e significantes, e, a despeito da discussão sobre conceito, função, estilo ou sentido (entre tantas outras), e até mesmo frente à anunciação de seu fim, continua a reinventar-se e aparecer sob diferentes roupagens, a ponto de prescindir até mesmo do vestir-se de qualquer coisa.

No contexto sociocultural contemporâneo e globalizado, a arte, mesmo quando incompreendida, tem seu valor amplamente reconhecido. Aliás, nunca se mobilizaram tantas fortunas e multidões em nome da arte. Por sua vez a persona do artista, antes incompreendida, desajustada e solitária, é respeitada, valorizada e desejada no séc. XXI. Seu status quo mudou; no entanto sua figura continua a emanar uma aura mística. Se no passado o artista, para o senso comum, era reconhecido como um sujeito excêntrico e aparentado com a loucura, no presente seu ofício ocupa um espaço privilegiado no imaginário coletivo, sendo ele considerado uma espécie de "eleito" que, por possuir dons e talentos, se destaca da multidão no exercício de sua liberdade. Ou seria no exercício de sua verdade?

Em algumas de suas reflexões Meyer Schapiro ${ }^{620}$ diz-nos que, embora a arte moderna e pós-moderna pareçam opor-se ao curso geral da vida, é justamente

\footnotetext{
${ }^{619}$ HOERNI, FISCHER e KAUFMANN, op. cit. In "Matéria e método em O Livro Vermelho", por Jill Mellick. (2019, p 319)

${ }^{620}$ SCHAPIRO, Meyer. A arte moderna séculos XIX e XX. São Paulo: Edusp, 1996. (p 252)
} 
nessa oposição que se desvelam sua humanidade e importância. Para ele - no seio de uma cultura de massa que é controlada por um sistema ameaçador para com a liberdade e a existência do indivíduo -, o artista contraria o pathos da redução ou fragilidade do ser ao manifestar sua liberdade e individualidade no exercício de seu ato criativo.

Pinturas e esculturas são os últimos objetos pessoais feitos a mão em nossa cultura. Quase tudo o mais é produzido industrialmente, em massa e através da divisão do trabalho. Poucas pessoas têm a felicidade de produzir algo que as represente, que brote inteiramente de sua mente e mãos e às quais possam fixar seus nomes. (...) O objeto da arte é, portanto, de maneira mais apaixonada do que nunca, motivo de espontaneidade ou sentimento intenso. A pintura simboliza um indivíduo que exerce a liberdade e o profundo engajamento pessoal em seu trabalho ${ }^{621}$.

Talvez por isso, no exercício de criar com a liberdade ancorada em sua verdade, o rastro do artista em seu fazer poético tenha criado uma nova estética. Assim, o processo passou a fazer parte da obra, vindo a ser, em alguns contextos, a própria obra de arte.

Daí a grande importância da marca, da pincelada, do gotejamento, da qualidade da substância da própria pintura e da superfície da tela como textura e campo operacional - todos sinais da presença ativista do artista. (...) que conferem em máximo grau o aspecto do livremente realizado ${ }^{622}$.

Parece-nos, contudo, existir algo invisível subjacente a essa aura advinda do artista e obra, e que nos toca; algo que nos chega por meio dessa estética estampada no rastro da presença que se fez ali, desvelando um sentido, ou um sentir, pelo qual todos ansiamos - a plenitude de sermos integralmente aquilo que se é. Jung denominou a isso de individuação. E a acuidade com que se acompanhou a si-mesmo em tal processo, procurando registrá-lo e trazê-lo ao mundo, oferece-nos a oportunidade de compreender o fenômeno psíquico que ocorre na criação artística, qual seja, a união do inconsciente com o consciente. Ainda que tal fenômeno não seja uma prerrogativa do fazer criativo, e seu resultado estético não seja também fator eletivo para tal, cumpre chamar a atenção

\footnotetext{
${ }^{621}$ Idem.

${ }^{622}$ SHAPIRO, op. cit. (1996, p 281)
} 
para a arte enquanto processo criativo com potencial de mobilizar o que há de essencial na natureza humana, e que, afinal, como disse Fayga, distingue o ser humano.

É nesse lugar que atua a arteterapia, processo psicoterapêutico contemporâneo, que utiliza a arte como facilitador do desenvolvimento, ampliação e integração da personalidade. Analisando sua experiência em retrospectiva, percebe-se que além de ponte histórica com a alquimia do medievo, sua experiência foi precursora de tal processo psicoterapêutico por meio do qual se entra em contato com os conteúdos psíquicos realizando-os pelo fazer artístico ${ }^{623}$. Tal processo poder-se-ia chamar de alquimia contemporânea, pois foi isso que Jung percebeu na correspondência dos processos alquímicos dos gnósticos ou dos processos anímicos da meditação taoísta, com seu próprio processo de confronto com o inconsciente por meio da elaboração estética - leia-se, também, material, plástica, lírica - de seus conteúdos, ou da prima matéria. Jung deu-se conta de que os processando na matéria, processava-os também psiquicamente, de modo semelhante aos dos alquimistas de outrora, que ao processar a matéria bruta buscavam transmutá-la em matéria nobre - simbolicamente, o ouro, a partir do qual podemos associar a realeza do que é autêntico e possui valor, qual seja nossa, realização como seres humanos.

Raro em sua experiência não foi apenas sua visada e a forma como se relacionou com a matriz da imaginação criadora; raro foi também o adjetivo que tal experiência imprimiu a sua obra, configurando-a em uma poética singular que terminou por exercer um grande atrativo.

Esta pesquisa nasceu do assombro diante de um livro que emergiu em um contexto de desvalia com aura de coisa rara, que nos dizia, na ocasião, mais do que somos capazes de compreender racionalmente. O que se impôs para mim, naquele momento, foi a pregnância da obra per se. Eu nada sabia de sua biografia $^{624}$; na verdade, pouco conhecia sobre o autor. Ao contrário do que pareceu a muitos, o desejo da pesquisa fez-se pela coisa em si (e não em defesa da

\footnotetext{
${ }^{623}$ Vide no capítulo 1 "Confronto com o inconsciente" e "O processo de criação d'O Livro Vermelho".

${ }^{624}$ De Hamel, mencionado no capítulo 3, defende a ideia de que alguns livros têm biografia.
} 
biografia ou obra científica do autor), pela vontade de conhecer a história que habitava aquele livro, e conhecer através de que mundos invisíveis ele se fez. Parafraseando Didi-Huberman ${ }^{65}$ - O que vemos, o que nos olha? Para mim, pessoalmente, quando essa experiência coloca-se diante de uma obra, há uma trama singular de espaço e tempo ${ }^{626}$ que se traduz em presença, presença da coisa que nos olha vindo ao encontro da nossa presença que a vê. E o que se faz presente ali, no entre "olhante" e "olhado"? Eu nomearia tal experiência como uma "estética da presença", não sei se existe tal conceito. Na minha percepção pessoal, é o obrar da obra, seu processo de criação, presentificado por meio da presença do artista atravessado pela emergência da arte enquanto força arquetípica, modelante, integralmente unido por meio de sua mente, mãos e coração no momento da criação. Penso e sinto que essa aura de presença é o que distingue uma obra de arte genuína. Genuína no sentido de trazer a autenticidade única e singular que se fez na personalidade do artista durante a criação, plasmando seu imaginário por meio das coisas do mundo, unindo, assim, céu e terra. É nesse lugar que se encontra o artista exercendo o poder de um olhar individual que, em sua tentativa de apreender o mundo, entrega-se ao seu trabalho e, longe das definições que lhe impõem as escolas e algumas categorias que tentam enquadrar a arte em definições que não lhe pertencem, está ali, executando sua obra "soberano em sua ruminação do mundo e encarnado até a medula ${ }^{627}$ ". Penso que é isso que nos impressiona na contemporaneidade, essa capacidade do artista, do poeta, do filósofo, de se colocar integralmente no corpo, nesse lugar do sentir, olhar e ver, ser e estar. E as "obras de arte, (são) existências misteriosas, cuja vida perdura ao lado da nossa, que passa ${ }^{628 \%}$. Testemunhas que nos trazem notícias sobre ser e estar nesse lugar, "alocado no corpo e no solo do mundo

\footnotetext{
${ }^{625}$ Em 1992, o filósofo e historiador Georges Didi-Huberman (2010) tomou emprestada uma expressão de James Joyce - na verdade, um fragmento extraído da fala de Stephen Dedalus, no clássico Ulisses -, alteroua levemente e utilizou-a como título de um de seus livros: O que vemos, o que nos olha. (N. da A.)

${ }^{626}$ Relendo Walter Benjamin.

627 MERLEAU-PONTY. O olho e o espírito. São Paulo: Cosacnaify, 2013. (p 18)

${ }^{628}$ RILKE, Rainer Maria. Cartas a um jovem poeta. Santa Maria: L\&PM, 2009. (pp 23-26)
} 
sensível $^{629 "}$ e interligado às coisas do céu, transcendente do lugar comum de nossa anestesia cotidiana. Indago junto com Merleau-Ponty:

Qual é, pois, essa ciência secreta que ele possui ou que ele busca? Essa dimensão segundo a qual Van Gogh quer ir "mais longe"? Esse fundamental da pintura e talvez de toda a cultura $?^{630}$.

Sinto que esse fundamental da cultura que todo mundo quer e o artista busca é da ordem do que não tem preço (logo, capaz de mover fortunas); por isso, quando realizado na obra verdadeira, na obra que "mundifica ${ }^{631}$ ", traz ao mundo notícias do mundo de lá. O que vemos, o que nos olha?

Evidente que essa percepção, pessoal e empírica, em âmbito acadêmico requer fundamentos. Entretanto, não podia deixar de mencioná-la, visto ter sido por força do espanto ante o "deslumbramento que nasce do simples fato de vermos, de sentirmos e de surgirmos, nós mesmos aí nesse duplo encontro, do mundo (que mundifica vigente na obra ${ }^{632}$ ) e do corpo (alocado em seu solo

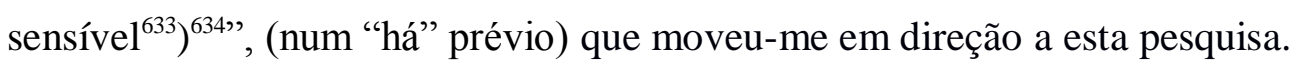

É preciso que o pensamento da ciência - pensamento de sobrevoo, pensamento do objeto em geral - torne a se colocar num "há" prévio, na paisagem, no solo do mundo sensível e do mundo trabalhado tais como são em nossa vida, por nosso corpo; não esse corpo possível que é lícito afirmar ser uma máquina de informação, mas esse corpo atual que chamo meu, a sentinela que se posta silenciosamente sob minhas palavras e sob meus atos ${ }^{635}$

\footnotetext{
${ }^{629}$ MERLEAU-PONTY, op. cit. (p 18)

${ }^{630}$ Idem.

${ }^{631}$ Em alusão à filosofia estética de Heidegger em A origem da obra de arte.

${ }^{632}$ Idem.

${ }^{633}$ MERLEAU-PONTY. Op. cit. (p 18)

${ }^{634}$ Ibid. In "Prefácio", por Claude Lefort.

${ }^{635}$ Ibid. (p 17)
} 


\section{O que vemos, o que nos olha?}

O Livro Vermelho de C. J. Jung foi concebido sem pretensões artísticas, no âmbito da arte moderna, e ainda que tenha permanecido sob sigilo, nasceu sob a insígnia da arte do seu tempo na qual a palavra de ordem foi ruptura. $\mathrm{O}$ artista moderno rompeu com o academicismo quebrando todos os paradigmas impostos pelo sistema da arte, e partiu face à expectativa de alçar novos voos, em busca de suas raízes, indo ao encontro da arte primitiva, genuína, arquetípica. Procurou também o lado científico da arte, motivado por compreender suas fórmulas; e, engajado em dialogar com a subjetividade do sujeito, encontrou na arte um caminho através de seu lado poético literário. No modernismo de todos os ismos, buscou-se a arte pela arte, e todas as impressões, expressões, sensações, percepções, abstrações, desconstruções, reais ou surreais, simbólicas, imaginárias ou oníricas, encontraram voz e corpo, tempo e espaço, traduzindo-se em obras visuais das mais diversas. Todas as poéticas que se poderiam imaginar vieram à luz por meio dessa abertura.

Não por acaso, talvez por sincronicidade, o processo de criação d'O Livro Vermelho rompe com o paradigma da feitura do livro através de um processo colaborativo e especializado em vigor desde o medievo, no qual, tradicionalmente, o autor escreve textos, não produz livros. Ao senso comum isso pode parecer irrelevante, no entanto, como vimos no capítulo 3, "Os manuscritos medievais iluminados", produzir um espécime desse tipo levava anos, às vezes a vida toda do monge, que, todavia, o produzia em colaboração com outros monges especialistas. Nesse sentido, ressaltamos o engajamento criativo de Jung ao desenvolver a técnica e elaborar os materiais por meio dos quais ele mesmo foi o escriba, o rubricador, o ilustrador e o iluminador. Riva Castleman, como vimos no capítulo 4, "O livro de/do artista", reconhece a complexidade de se produzir livros, e, devido a isso, contempla com especial atenção os artistas que conseguiram gerir todo o processo de criação, dados os fatores e manejo de materiais que naturalmente ficam fora do controle ou do alcance do $\operatorname{artista}^{636}$. Consoante com tal perspectiva, Ulisses Cárrion, um dos primeiros a escrever a

${ }^{636}$ CASTLEMAN, op. cit. (1994) 
respeito do campo, visto também no capítulo 4, postulou em seu artigo-manifesto (1975):

Um livro pode ser o recipiente acidental de um texto, cuja estrutura é irrelevante para o livro: estes são os livros das livrarias e das bibliotecas. Um livro também pode existir como uma forma autônoma e independente, incluindo talvez um texto que seja parte integrante e que enfatize essa forma: aqui começa a nova arte de fazer livros. Na velha arte, o escritor não se julga responsável pelo livro. Ele escreve o texto. O resto é feito pelos empregados, os artesãos, os trabalhadores, os outros. Na nova arte o escritor assume a responsabilidade pelo processo inteiro. $\mathrm{Na}$ velha arte o escritor escreve textos, na nova arte, o escritor faz livros $^{637}$.

Essa mudança de paradigma veio a ser um dos principais pressupostos do campo do livro de artista que recoloca na história o livro como obra de arte. Tal campo, entretanto, tendo germinado nos primórdios da arte moderna, só veio configurar-se como categoria artística na arte contemporânea. Fortemente caracterizada como uma arte conceitual, experimental, efêmera (até mesmo imaterial), e com foco nos processos através dos quais o artista pode registrar e estudar sua poética individual - e, nesse âmbito, amplia-se ainda para novos sujeitos e novos territórios, nos quais o campo específico do livro de artista, após ficar circunscrito pela arte conceitual em seu sentido stricto, detém um certo protagonismo, pois, uma das propostas orientadoras é o foco nos processos de criação, por meio dos quais facilita ao artista estudar-se a si mesmo ${ }^{638}$. Naturalmente, o livro passou a ser um campo relacional na arte, utilizado para o registro de tais processos, sobretudo porque também resulta em objeto poético. Em primeira instância "através dos manifestos, textos e diários de bordo dos artistas inovadores do modernismo, os escritos de artistas emergiram intervindo no destino e na arte vigente de então. Fato é que a relação do artista com a palavra e com a escrita, embora deslocada para outras bases - de cunho reflexivo, conceitual e teórico -, consolidou-se como um dos marcos da arte contemporânea ${ }^{639 "}$.

\footnotetext{
${ }^{637}$ CÁRRION, op. cit. (2011, p 14)

${ }^{638}$ DERDYCK, op. cit. In "Entre páginas e não páginas: breve inventário de livros de artista", por Galciani Neves. São Paulo: Senac, 2013. (p 63)

${ }^{639}$ Idem.
} 
E, não por acaso, talvez por sincronicidade, é nessa esfera que a obra emerge quando os processos de criação estão em pauta. Há fóruns, livros, documentários, e teses que tentam alcançar, mapear e explicar a criatividade, reconhecida especialmente no exercício poético do artista. Destacamos aqui, mais uma vez, a fim de concatenar as ideias, que o livro em questão originou-se de um autoexperimento por meio do qual o autor, estudando-se a si mesmo frente a um fenômeno subjetivo, elaborou uma nova psicologia. $O$ Livro Vermelho configurou-se como campo de processo criativo, e ainda, como produto desse campo $^{640}$. Ainda que não houvesse pretensão artística, a obra, face à demanda contemporânea, impõe-se, gerando processos diversos de assimilação. Conforme James Hillman fala em diálogo com Sonu Shamdasani: “Agora que o livro está acessível, há algo no coletivo contemporâneo que quer o livro ${ }^{641}$ ”. Inclusive, ressaltamos que, ao início da escrita, em 2017, a bibliografia sobre o tema era praticamente inexistente (e ainda é), entretanto, ao final da elaboração da presente pesquisa foi publicado A arte de C. G. Jung pela editora Vozes, o que demonstra a assimilação e interesse do público pelo assunto.

Considero então, de uma perspectiva mais ampla e não reducionista, fundamentada nos preceitos ${ }^{642}$ da arte moderna e contemporânea, que $O$ Livro Vermelho não foi o "livro do artista" C. G. Jung; foi, contudo, seu "livro de artista".

Nosso argumento - ao contrapor o significado da preposição "de" ao significado da contração dessa mesma preposição com o artigo "o" - tem por propósito provocar a reflexão sobre a diferença fundamental que, no entanto, se mostra sutil: a preposição pura abre o leque, ampliando o campo, ou seja, livro "de" artista designa um estilo, um "à moda de", enquanto a contração com o artigo "o", redundando no "do", limita-o, fecha-o, provocando uma interpretação

\footnotetext{
${ }^{640}$ SILVEIRA, op. cit. (2018, p 21)

${ }^{641}$ HILLMAN, James; SHAMDASANI, Sonu. Lamento dos Mortos - A psicologia depois de O Livro Vermelho de Jung. Petrópolis: Vozes, 2016. Hillman foi importante psicólogo americano, autor de inúmeros livros e o primeiro diretor do Instituto C. G. Jung em Zurique. Shamdasani já referido anteriormente nesta dissertação.
}

\footnotetext{
${ }^{642}$ Para não deixar dúvidas, circunscrevemos a tônica de vanguarda e ruptura da arte moderna, o conceito de campo expandido de Rosalind Krauss, e o postulado de Joseph Beuys: "Cada homem, um artista".
} 
equivocada, como se tal modelo fosse prorrogativa de alguém que se colocou socialmente sob o status quo de artista. Sublinhamos, inclusive, que o termo atribuído ao campo vale-se da proposição - livro de artista -, todavia, nos parece que alguns teóricos o leem como "livro do artista".

Não vamos nos deter nas intermináveis discussões e desentendimentos que tentam dar conta do campo, delimitando limites que o próprio objeto e seu contexto histórico não impõem. Ademais, as questões dos limites e preceitos do campo está, todavia, em aberto. Contudo é preciso lembrar o papel preponderante dos escritores face à história do livro, e não nos parece coerente que, dentro de perspectiva tão ampla, eles fossem excluídos. Sabemos que a qualificação de um artista como tal, "dentro do sistema da arte", depende, sobretudo da escolha do indivíduo, ou da crítica de arte, dentre outras coisas. Entretanto, nos parece que nossa visada a partir do objeto, isto é, d'O Livro Vermelho em si, vai ao encontro do que está sendo proposto no mundo em relação ao assunto, o título do livro recém-publicado não defende a ideia de que Jung foi um artista; antes, chancela o direito genuíno de qualquer ser humano exercer a sua arte. Se o produto de seu exercício está sendo assimilado pelo público, cabe à história se debruçar sobre o fenômeno.

Considero, ainda, conforme fundamentado no capítulo 2, "O livro como obra de arte", com base nas premissas apresentadas para qualificação ${ }^{643} \mathrm{de}$ livro raro, que dentre os cinco critérios apresentados, três referências coadunam para a fundamentação do livro em questão como livro raro, precioso e único: Aspectos bibliográficos, valor cultural da obra, e pesquisa bibliográfica, reconhecidos nas seguintes especificidades:

a) Aspectos bibliográficos dos volumes produzidos de modo artesanal, independentemente de sua datação - Identificados na natureza e nos materiais utilizados na criação do $L V$ - tais quais pergaminho, encadernação luxuosa e original, tintas; assim como nas ilustrações e iluminuras criadas com técnicas artesanais de têmpera e aquarela.

\footnotetext{
${ }^{643}$ PINHEIRO, Ana V. T. da Paz. Que É Livro Raro? Uma metodologia para o estabelecimento de critérios de raridade bibliográfica. Rio de Janeiro: Presença, 1989.
} 
b) $\mathrm{O}$ valor cultural da obra - Reconhecido na publicação e edição especial a partir do fac-símile do livro único e original, e no reconhecimento póstumo da obra como eixo central para a compreensão da obra de C. G. Jung e da gênese de sua Psicologia Analítica, tratados à luz da época em que foram pensados e escritos, tornando-o, com isso, obra científica de referência datada do período de ascensão daquela ciência.

c) Pesquisa bibliográfica - A partir da unicidade e raridade da obra que se apresenta originalmente como livro único, bem como a preciosidade e celebridade contidas na obra que a tornam atrativa e procurada por bibliófilos - por quaisquer razões - e/ou para estudo e pesquisa de eruditos.

Ressaltamos, ainda, consoante com a fundamentação proposta, a importância intrínseca da obra em sua área como fator preponderante na determinação de raridade, o que equivaleria dizer, na contemporaneidade, que tal livro é uma obra prima.

Acredito que a pesquisa possa contribuir para diálogos, reflexões e ampliações para o campo extremamente fértil que é o livro de artista. Penso que a ontologia do livro proporciona um dos terrenos mais férteis para processos criativos, e que o livro, como espaço de criação, ainda tem muito caminho a oferecer.

Considero, e acredito, que o percurso que a pesquisa permitiu-nos fazer pela história do livro por meio da perspectiva da arte, presente desde a origem, evolução, processos, e como próprio campo do fazer arte, pode ampliar o olhar para com o livro, e para a arte de fazer livros, contribuindo para o resgate de seu valor cultural e artístico.

Penso que ao campo da psicologia a pode fomentar diálogos e contribuir com novas perspectivas ao encontro do que seria uma psicologia da criação, face à possibilidade de encontrar-se uma outra linguagem - mitopoética, lírica, artística -, que seja capaz de dialogar com a alma, como tem buscado realizar a arteterapia; afinal a psicologia pretender-se-ia uma ciência da alma. 
Quando comecei este trabalho havia espanto e encantamento diante da obra; e, subjacente, meu propósito, o livro. Chego ao fim do caminho percorrido com profundo respeito e admiração pela obra de Jung e por sua pessoa, a quem tive oportunidade de conhecer melhor, e levo comigo, face ao meu trabalho com o livro, um forte sentimento da responsabilidade ética e estética.

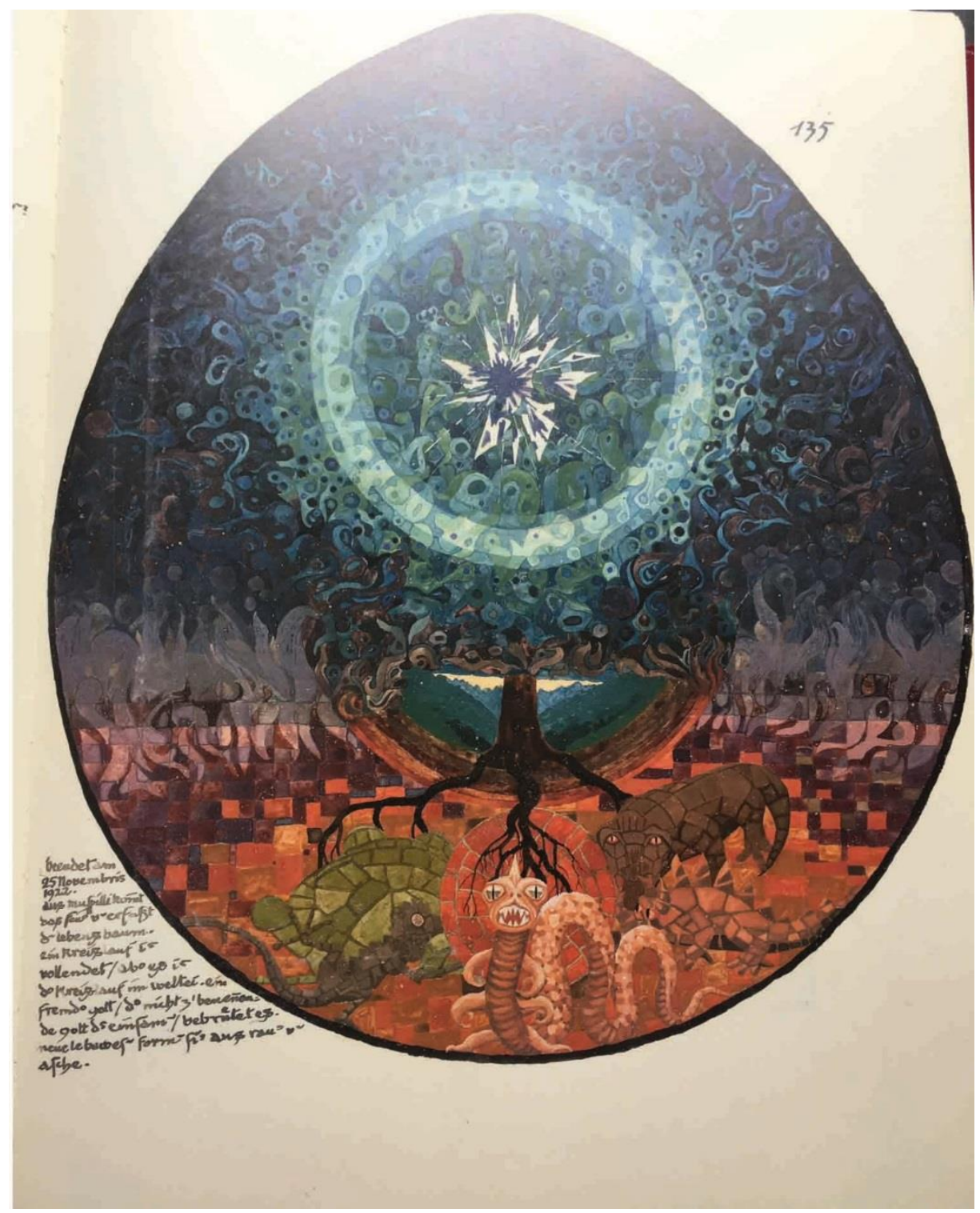

Figura 39: Ilustração sem título (p 135/LV) 


\section{REFERÊNCIAS BIBLIOGRÁFICAS}

ARAÚJO, E. A construção do livro. Rio de Janeiro: Lexikon, 2008.

ARGAN, Giulio Carlo. Arte Moderna. Editora Companhia das Letras, São Paulo, 2ªdição, 1992.

BELLO, Susan. Pintando sua alma: método de desenvolvimento da personalidade criativa. Rio de Janeiro: Wak, 2007.

BENJAMIN, Walter. A obra de arte na época de sua reprodutibilidade técnica. Porto Alegre: Ed. Zouk, 2012.

BOECHAT, W. O Livro Vermelho de Jung - jornada para profundidades desconhecidas. Rio de Janeiro: Vozes, 2014.

BORGES, J. L. Cinco visões pessoais. In “O livro”. Brasília: Ed. UnB, 1985.

BRIGGS E BURKE, Asa e Peter. Uma história social da mídia. Rio de Janeiro: Zahar, 2004.

CARDOSO, P. S. "A Lithos Edições de Arte e as transições de uso das técnicas de reprodução de imagens". Dissertação de Mestrado em História Social da Cultura. PUC-Rio, 2008

CARRIÓN, U. A nova arte de fazer livros. Belo Horizonte: Ed. C/Arte, 2011.

CARUANA, L. O primeiro manifesto da arte visionária. Curitiba: URCI-GLP, 2013.

CASTLEMAN, R. A century of artists books, The Museum of Modern Art: Distributed by H.N. Abrams, 1994

Catálogo "Breve História Del Grabado de Metal (Intaglio) Siglos XV al XX". Museu de Belas Artes. Caracas / Venezuela 1974. 
CAVALCANTI, M. Confraria Van Gogh - a vida secreta de um livro de biblioteca pública. Divino de São Lourenço: Semente Editorial, 2010.

CAVALlO, CHARTIER, Guglielmo e Roger. História da leitura no mundo ocidental I. São Paulo. Ática, 1998.

DAHLKE, Rüdiger. Mandalas. São Paulo: Pensamento, 1985.

DE HAMEL, Christopher. Manuscritos Notáveis. São Paulo: Companhia das Letras, 2017.

DERDYCK, Edith. Entre ser um e ser mil - o objeto livro e suas poéticas. In "Entre páginas e não páginas: breve inventário de livros de artista" por Galciani Neves. São Paulo: Senac, 2013. (p 63)

FAILlACE, Vera Lúcia Miranda. Catálogo dos Livros de Horas da Biblioteca Nacional. Rio de Janeiro: FBN (Fundação Biblioteca Nacional), 2016.

FARIA, Maria Isabel, e PERICÃO, Maria das Graças. Dicionário do Livro. São Paulo: Almedina, 2001. (p 209)

FEBVRE e MARTIN, Lucien, Henri-Jean. O aparecimento do livro. São Paulo: Edusp, 2017.

FISCHER, Steven Roger. História da Escrita. São Paulo: UNESP, 2009.

GEORGES, Jean. Escrita: memória dos homens. Rio de Janeiro: Objetiva, 2008.

GOMBERG, Felip. "A aura do livro na era de sua reprodutibilidade técnica". Dissertação de Mestrado do Departamento de Comunicação Social da PUC-Rio, 2006.

GOMBRICH, E. H.. A História da Arte. Rio de Janeiro: LTC, 16a edição, 2015.

GOMIERO, Eric Rahal. "Autenticidades - Um livro de Artista”. Dissertação apresentada ao Programa de Pós-Graduação em Artes, área de pesquisa Poéticas Visuais. USP. 2010. 
HASLAM, Andrew. O livro e o designer II - Como criar e produzir livros. São Paulo: Rosary, 2007.

HEIDEGGER, Martin. Ser e Tempo. Petrópolis: Vozes, 10ª edição, 2015.

HILLMAN, James; SHAMDASANI, Sonu. Lamento dos Mortos - A psicologia depois de O Livro Vermelho de Jung. Petrópolis: Vozes, 2016

HOERNI, FISCHER E KAUFMANN, Ulrich, Thomas e Bettina. A arte de C. J. Jung. In "Uma seleção de iniciais iluminadas de O Livro Vermelho". Petrópolis: Vozes, 2017.

JEAN, Georges. A escrita - memória dos homens. Rio de Janeiro: Objetiva, 2008.

JUNG, C. G. A natureza da Psique. Petrópolis: Vozes, 2013.

JUNG, C. G. Estudos Alquímicos. In "Prefácio". Petrópolis: Vozes, 2003.

JUNG. C. G. O Homem e seus símbolos. Rio de Janeiro: Nova Fronteira, 2008.

JUNG, C. G. O Livro Vermelho de C. G. Jung. Petrópolis: Vozes, edição com ilustrações, 2017.

JUNG, C. G. O Livro Vermelho de C. G. Jung. Petrópolis: Vozes, edição sem ilustrações, 2017.

JUNG, C. G. Os arquétipos e o inconsciente coletivo. Petrópolis: Vozes, $4^{\text {a }}$ edição, 2006.

JUNG, C. G.Memórias, sonhos e reflexões. Rio de Janeiro: Nova Fronteira, 30ª edição, 2016

JUNG, C. G.O espírito na arte e na ciência. Petrópolis: Vozes, 2013(b).

JUNG, WILHELM. C. G., R. O segredo da flor de ouro. Petrópolis: Vozes, 2013(a).

LYONS, Martyn. Livro, uma história viva. São Paulo: Senac, 2011. 
MARTINS, Wilson. A palavra escrita: história do livro, da imprensa e da biblioteca. São Paulo: Anhembi, 1957.

MEREGE, Ana Lucia. In "História do Livro Manuscrito". IBICT-UFRJ/ECO.

MERLEAU-PONTY. O olho e o espírito. São Paulo: Cosacnaify, 2013.

MORAES, Eliana. Pensando a Arteterapia. Semente Editorial: Divino de São Lourenço, 2018.

OSTROWER, F. Criatividade e processos de criação. Petrópolis: Vozes, 1997

PAREYSON, Luigi. Estética - teoria da formatividade. Petrópolis: Vozes, $3^{\mathrm{a}}$ edição, 1993.

PEYRE, YVES. Peinture et Poésie - le dialogue par le livre 1874-2000. Paris: Editions Gallimard, 2001

PINHEIRO, Ana V. T. da Paz. Que É Livro Raro? Uma metodologia para o estabelecimento de critérios de raridade bibliográfica. Rio de Janeiro: Presença, 1989.

Revista Gráfica \# 75/76, 2011.

REY, Sandra. "A dimensão crítica dos escritos de artistas na arte contemporânea”. In PÓS: Belo Horizonte, 2008. (v. 1, n. 1, pp 8-15)

RILKE, Rainer Maria. Cartas a um jovem poeta. Santa Maria: L\&PM, 2009.

ROCHA, Christiana Arruda Lee. "O livro como obra-de-arte: critérios teóricos para conservação de obras raras". 2008.

SCHAPIRO, Meyer. A arte moderna séculos XIX e XX. São Paulo: Edusp, 1996.

SILVEIRA, Nise. Imagens do Inconsciente. Rio de Janeiro: Editorial Alhambra,

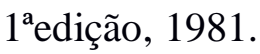

SILVEIRA, Nise. Jung: vida e obra. São Paulo: Paz e Terra, 2011. 
SILVEIRA, Paulo. A Página Violada - Da ternura à injúria na construção de livros de artista. Porto Alegre: Editora da UFRGS, $2^{a}$ edição, 2008.

SOUZA, F. L. M. "O Livro Vermelho de Jung: As polaridades da psique e as concepções de Deus". Tese de Doutorado apresentada ao Programa de PósGraduação em Ciência da Religião, área de concentração Filosofia da Religião, do Instituto de Ciências Humanas da Universidade Federal de Juiz de Fora / MG, 2015 .

SPINELLI, Daniela. In "William Morris e sua crítica moral do sistema produtivo capitalista" publicado no MORUS - Utopia e Renascimento, 12, 2017. Doutora em Teoria e História Literária pela Universidade Estadual de Campinas Unicamp. É pesquisadora colaboradora do departamento de Pós-Graduação em História da Universidade Federal de São Paulo.

TV Cria Arte, Arte Monástica III - Iluminuras, disponível em <https://www.youtube.com/watch?v=dV_WK3W-mSE>, Acesso em 10/12/2019 às 00:37

TV Cria Arte, Arte Paleocristã I - Fase Catacumbária, disponível em <www.youtube.com/watch?v=7uIh8PLJP44>, Acesso em 23/09/2019 as 22:00.

TV Cria Arte, Arte Paleocristã II - Fase Basilical, disponível em <www.youtube.com/watch?v=3Ae0ZipoXXw>, Acesso 29/09/2019 às 18:41.

TV Cria Arte, Arte Paleocristã III - Simbologia, disponível em <www.youtube.com/watch?v=_XD49dwiKQE>, Acesso em 23/09/2019 as 22:53.

VARELA, Marcos Baptista. "A Xilogravura Expressionista Brasileira". Dissertação de Mestrado em História da Arte. Escola de Belas-Artes, Universidade Federal do Rio de Janeiro, 1997. (p 34)

VENEROSO, Maria do Carmo de Freitas. "Livros de artista e livros raros: aproximações" in Perspectivas em Ciência da Informação, v.22, número especial, jul. 2017. 
VENEROSO, Maria do Carmo Freitas. In "Perspectivas do livro de artista, um relato". Belo Horizonte : UFMG : PÓS : Belo Horizonte v.2 n.3 2012.

VISALLI, GODOI, Angelita Marques e Wanessa. "Estudos sobre imagens medievais: o caso das iluminuras". 2016. Disponível em <http://dx.doi.org/10.4025/dialogos.v20i3.33666> 